PENGARUH ASIMETRI INFORMASI TERHADAP SENJANGAN ANGGARAN PADA PENGANGGARAN PARTISIPATIF DENGAN ORIENTASI ETIKA SEBAGAI VARIABEL MODERATING

\title{
SKRIPSI
}

Diajukan kepada Fakultas Ekonomi Universitas Negeri Yogyakarta untuk Memenuhi Sebagian Persyaratan guna Memperoleh Gelar Sarjana Ekonomi

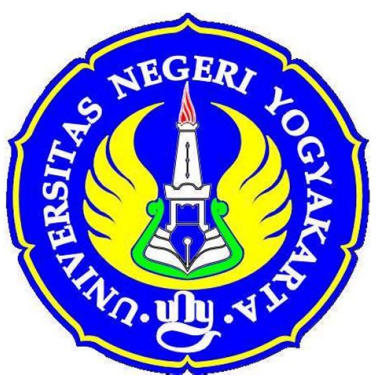

Oleh :

RIA AFRIANI HARININGTYAS

10412141026

PROGRAM STUDI AKUNTANSI

JURUSAN PENDIDIKAN AKUNTANSI

FAKULTAS EKONOMI

UNIVERSITAS NEGERI YOGYAKARTA 2014 


\title{
PENGARUH ASIMETRI INFORMASI TERHADAP SENJANGAN ANGGARAN PADA PENGANGGARAN PARTISIPATIF DENGAN ORIENTASI ETIKA SEBAGAI VARIABEL MODERATING
}

\author{
PROPOSAL SKRIPSI
}

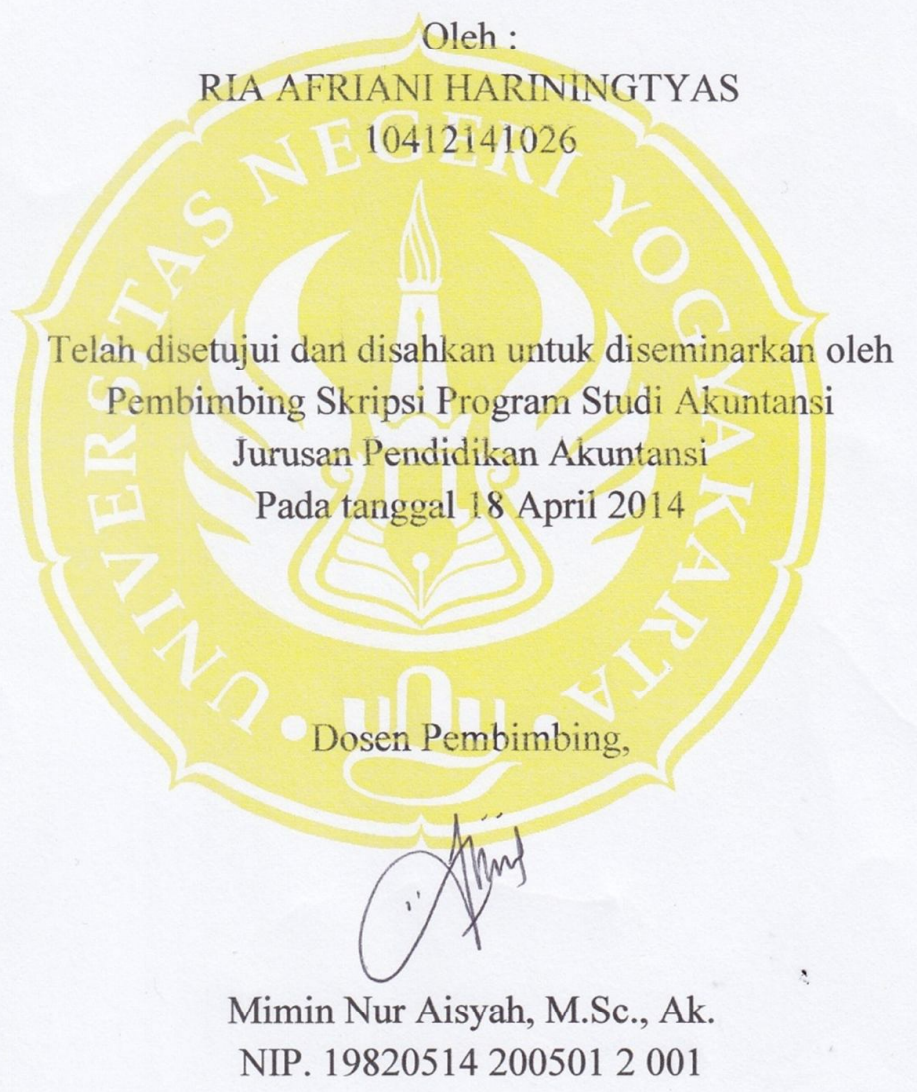




\section{PENGARUH ASIMETRI INFORMASI TERHADAP SENJANGAN ANGGARAN PADA PENGANGGARAN PARTISIPATIF DENGAN ORIENTASI ETIKA SEBAGAI VARIABEL MODERATING}

PROPOSAL SKRIPSI

Oleh :

RIA AFRIANI HARININGTYAS

10412141026

Telah diseminarkan oleh

Narasumber Skripsi Program Studi Akuntansi

Jurusan Pendidikan Akuntansi

Pada tanggal 25 April 2014

Dosen Pembimbing

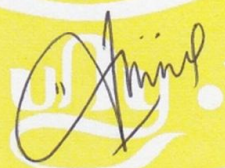

Mimin Nur Aisyah, M.Sc., Ak.

NIP. 198205142005012001

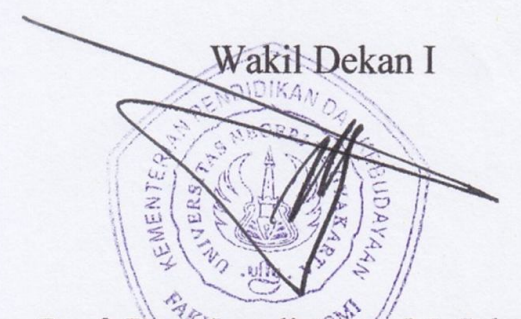

Prof. Dr. Moerdiyanto, M. Pd., MM.

NIP. 195805071983031001 


\title{
PENGARUH ASIMETRI INFORMASI TERHADAP SENJANGAN ANGGARAN PADA PENGANGGARAN PARTISIPATIF DENGAN ORIENTASI ETIKA SEBAGAI VARIABEL MODERATING
}

\author{
SKRIPSI
}

Oleh :

RIA AFRIANI HARININGTYAS

10412141026

\begin{abstract}
Telah disetujui dan disahkan
Pada tanggal 20 Juni 2014
\end{abstract}

Untuk dipertahankan di depan Tim Penguji Skripsi

Program Studi Akuntansi

Jurusan Pendidikan Akuntansi Fakultas Ekonomi

Universitas Negeri Yogyakarta

Disetujui

Dosen Pembimbing,

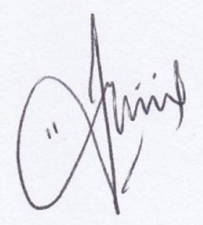

Mimin Nur Aisyah, M.Sc., Ak.

NIP. 198205142005012001 


\section{PENGESAHAN}

Skripsi yang berjudul:

\section{"PENGARUH ASIMETRI INFORMASI TERHADAP SENJANGAN ANGGARAN PADA PENGANGGARAN PARTISIPATIF DENGAN ORIENTASI ETIKA SEBAGAI VARIABEL MODERATING"}

Oleh:

\section{RIA AFRIANI HARININGTYAS}

NIM. 10412141026

Telah dipertahankan di depan Dewan Penguji pada tanggal 27 Juni 2014 dan

Nama dinyatakan lulus.

\section{DEWAN PENGUJI}

\section{Prof. Sukirno, M. Si., Ph. D}

Jabatan

\section{Tanda Aangan Tanggal}

Mimin Nur Aisyah, M. Sc., Ak. Sekretaris Penguji

Dr. Ratna Candra Sari, M. Si., Ak. Penguji Utama

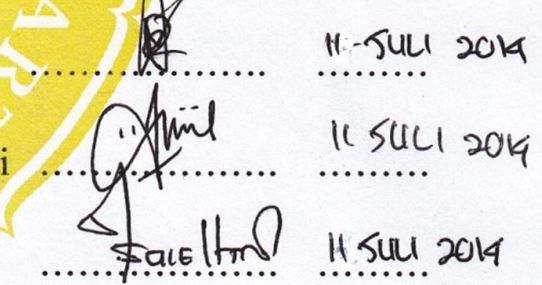

Yogyakarta, [/ Juli 2014

Fakultas Ekonomi

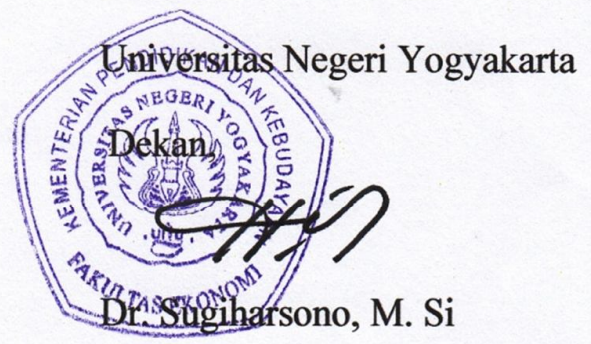

NIP. 1955032819831002 \& 


\section{PERNYATAAN KEASLIAN SKRIPSI}

Yang bertanda tangan di bawah ini:

$\begin{array}{ll}\text { Nama } & : \text { Ria Afriani Hariningtyas } \\ \text { NIM } & : 10412141026 \\ \text { Program Studi } & : \text { Akuntansi } \\ \text { Fakultas } & : \text { Ekonomi } \\ \text { Judul } & \text { : PENGARUH ASIMETRI INFORMASI } \\ & \text { TERHADAP SENJANGAN ANGGARAN } \\ & \text { PADA PENGANGGARANPARTISIPATIF } \\ & \text { DENGAN ORIENTASI ETIKA SEBAGAI } \\ & \text { VARIABEL MODERATING }\end{array}$

Dengan ini saya menyatakan bahwa skripsi ini benar-benar karya saya sendiri. Sepanjang pengetahuan saya tidak terdapat karya atau pendapat yang ditulis atau diterbitkan orang lain kecuali sebagai acuan atau kutipan dengan mengikuti tata penulisan karya ilmiah yang lazim. Demikian, pernyataan ini saya buat dalam keadaan sadar dan tidak dipaksakan.

Yogyakarta, 18 Juni 2014

Penulis,

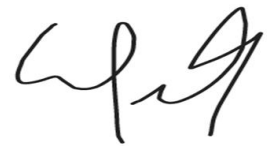

Ria Afriani Hariningtyas

NIM. 1041214102 


\section{MOTTO}

"Achievement only comes with hard work, dedication, and the help of the

Almighty"

(Mufti Ismail Menk)

"Patience is not the ability to wait but how you act while you're waiting"

(Joyce Meyer)

"Nothing worth having comes easy"

(Unknown)

\section{PERSEMBAHAN}

Skripsi ini ingin kupersembahkan kepada:

1. Ibu dan Bapak yang selalu mendukung dan mendoakanku.

2. Saudaraku, Devi Putri Hariningtyas, Vivien Nur Vita Dewi dan Titin Prihatiningsih, Okvi Widriastuti yang selalu menyemangatiku. 


\title{
PENGARUH ASIMETRI INFORMASI TERHADAP SENJANGAN ANGGARAN PADA PENGANGGARAN PARTISIPATIF DENGAN ORIENTASI ETIKA SEBAGAI VARIABEL MODERATING
}

\author{
Oleh: \\ RIA AFRIANI HARININGTYAS \\ 10412141026
}

\begin{abstract}
ABSTRAK
Penelitian eksperimen ini bertujuan untuk mengetahui (1) pengaruh asimetri informasi terhadap senjangan anggaran; (2) pengaruh relativisme pada hubungan asimetri informasi terhadap senjangan anggaran; (3) pengaruh idealisme pada hubungan asimetri informasi terhadap senjangan anggaran; (4) pengaruh orientasi etika pada hubungan asimetri informasi terhadap senjangan angggaran.

Populasi penelitian ini adalah mahasiswa S1 jurusan Akuntansi angkatan 2010 dan 2011 serta mahasiswa S1 jurusan Pendidikan Akuntansi Universitas Negeri Yogyakarta angkatan 2011 yang berjumlah 209 orang. Jumlah sampel yang mengikuti eksperimen sebanyak 175 mahasiswa. Teknik pengambilan sampel menggunakan purposive sampling dengan kriteria sampel telah lulus mata kuliah Akuntansi Manajemen atau Penganggaran atau Sistem Pengendalian Manajemen. Teknik analisis data yang digunakan dalam penelitian ini adalah ANOVA yang disertai dengan uji Post Hoc Scheffe.

Hasil penelitian menunjukkan bahwa tingkatan asimetri informasi berpengaruh terhadap senjangan anggaran. Hal tersebut ditunjukkan oleh Fhitung $>$ Ftabel, yaitu 18,826 > 3,07 dan p-value 0,000<0,05. Pada uji Scheffe, kelompok tidak ada asimetri informasi dan asimetri informasi tinggi memiliki perbedaan rata-rata nilai senjangan anggaran yang paling besar, yaitu 0,3224 dengan signifikansi $0,000<0,05$. Kelompok relativisme tinggi tidak memiliki rata-rata nilai senjangan anggaran yang lebih tinggi daripada kelompok relativisme rendah. Hal tersebut ditunjukkan oleh Fhitung < Ftabel, yaitu 0,307< 3,07 dan $p$-value $0,736>0,05$. Kelompok idealisme tinggi tidak memiliki ratarata nilai senjangan anggaran yang lebih rendah daripada kelompok relativisme rendah. Hal tersebut ditunjukkan oleh Fhitung $<$ Ftabel, yaitu 0,127 <3,07 dan $p$ value $0,881>0,05$. Orientasi etika tidak berpengaruh pada hubungan asimetri informasi terhadap senjangan anggaran. Hal tersebut ditunjukkan oleh Fhitung < Ftabel, yaitu $0,127<3,07$ dan $p$-value $0,893>0,05$.
\end{abstract}

Kata kunci : Senjangan Anggaran, Asimetri Informasi, Relativisme, Idealisme, Orientasi Etika. 


\section{KATA PENGANTAR}

Puji syukur kehadirat Allah SWT yang telah melimpahkan nikmat-Nya sehingga penulis dapat menyelesaikan Tugas Akhir Skripsi dengan judul “Pengaruh Asimetri Informasi terhadap Senjangan Anggaran pada Penganggaran Partisipatif dengan Orientasi Etika Sebagai Variabel Moderating", dengan lancar. Penulis menyadari bahwa tanpa bimbingan dari berbagai pihak, Tugas Akhir Skripsi ini tidak dapat diselesaikan dengan baik. Oleh karena itu, pada kesempatan ini penulis ingin mengucapkan terima kasih kepada:

1. Prof. Dr. Rochmat Wahab, M.Pd., M.A., Rektor Universitas Negeri Yogyakarta.

2. Dr. Sugiharsono, M.Si., Dekan Fakultas Ekonomi Universitas Negeri Yogyakarta.

3. Sukirno, M.Si, Ph.D., Ketua Jurusan Pendidikan Akuntansi Universitas Negeri Yogyakarta.

4. Dhyah Setyorini, M.Si., Ak., Ketua Program Studi Akuntansi Universitas Negeri Yogyakarta.

5. Mimin Nur Aisyah, M.Sc., Ak., dosen pembimbing yang telah memberikan perhatian, bimbingan, serta ilmu dalam menyusun Tugas Akhir Skripsi.

6. Dr. Ratna Candra Sari, SE., M.Si., Ak., dosen narasumber yang telah memberikan ilmu yang bermanfaat selama penelitian. 
7. Dosen dan staf karyawan Universitas Negeri Yogyakarta yang telah membantu penulis dalam menyelesaikan Tugas Akhir Skripsi.

8. Mahasiswa Akuntansi angkatan 2010 dan 2011 serta mahasiswa Pendidikan Akuntansi angkatan 2011 yang telah bersedia menjadi partisipan.

9. Semua pihak yang tidak dapat penulis sebutkan satu per satu.

Semoga skripsi ini bermanfaat untuk semua pihak. Penulis menyadari skripsi ini masih jauh dari kesempurnaan maka saran dan kritik sangat penulis harapkan.

Yogyakarta, 19 Juni 2014

Penulis,

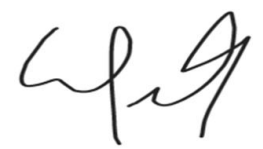

Ria Afriani Hariningtyas

NIM. 10412141026 


\section{DAFTAR ISI}

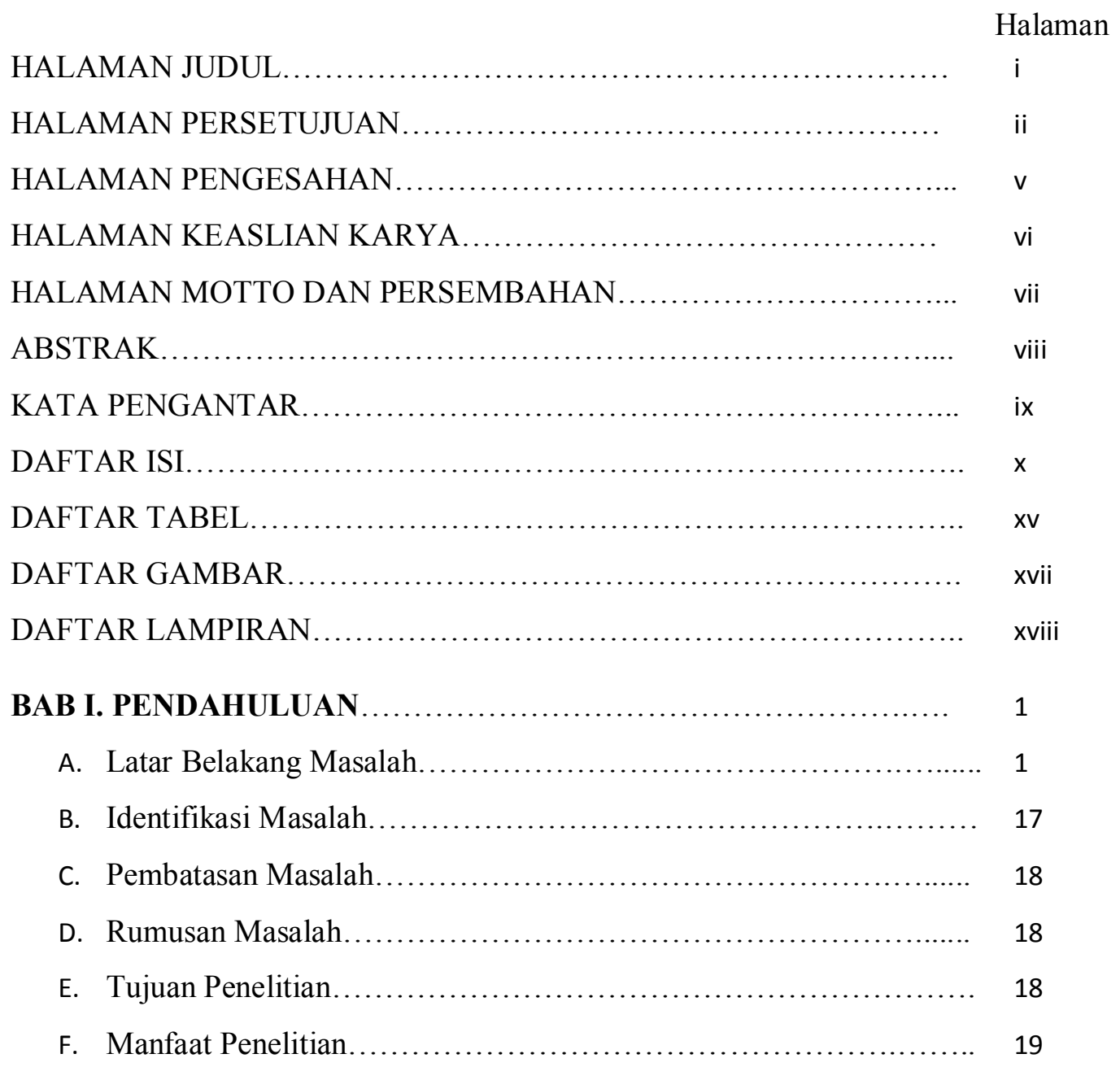

BAB II. KAJIAN TEORI DAN PENELITIAN YANG RELEVAN ..........21

A. Kajian Teori............................................... 21

1. Teori Agensi............................................ 21

2. Anggaran............................................... 22

a. Pengertian Anggaran................................... 22

b. Karakteristik Anggaran............................... 24

c. Keefektifan Anggaran................................. 25

d. Fungsi Anggaran...................................... 26 
e. Manfaat Anggaran........................................... 28

f. Penyusunan Anggaran..................................... 31

3. Partisipasi Anggaran..................................... 34

a. Pengertian Partisipasi Anggaran......................... 34

b. Alasan Pelaksanaan Partisipsi Anggaran................... 35

c. Manfaat Partisipasi Anggaran........................... 36

d. Permasalahan Partisipasi Anggaran..................... 39

4. Senjangan Angggaran.................................. 40

a. Pengertian Senjangan Anggaran......................... 40

b. Penyebab Senjangan Anggaran............................ 41

c. Dampak Senjangan Anggaran........................... 44

d. Mencegah Senjangan Anggaran........................... 46

5. Insentif............................................ 47

a. Pengertian Kompensasi............................... 47

b. Pengertian Insentif................................... 48

c. Tujuan Insentif..................................... 48

d. Jenis Insentif........................................ 50

e. Sistem Kompensasi................................. 50

6. Asimetri Informasi....................................... 51

a. Pengertian Asimetri Informasi........................ 51

b. Jenis Asimetri Informasi................................... 53

c. Indikator Asimetri Informasi............................. 54

d. Dampak Asimetri Informasi.......................... 55

7. Orientasi Etika......................................... 56

a. Pengertian Orientasi Etika............................... 56

b. Karakteristik Orientasi Etika............................ 57

1) Relativisme......................................... 58

2) Idealisme...................................... 58

c. Klasifikasi Orientasi Etika................................ 59

1) Situationism .............................................. 59 
2) Absolutism............................................ 60

3) Subjectivism................................... 60

4) Exceptionism.......................................... 61

d. Orientasi Etika terhadap Senjangan Anggaran............. 62

e. Indikator Orientasi Etika................................. 64

1) Relativisme....................................... 64

2) Idealisme........................................ 66

B. Penelitian yang Relevan........................................... 67

C. Kerangka Berpikir........................................ 69

D. Paradigma Penelitian.......................................... 79

BAB III. METODE PENELITIAN .................................. 81

A. Desain Penelitian............................................... 81

B. Kasus Eksperimen........................................... 82

C. Prosedur Penelitian.......................................... 84

D. Definisi Operasional Variabel................................ 86

1. Variabel Dependen......................................... 87

2. Variabel Independen................................... 88

3. Variabel Moderating.................................... 90

E. Populasi.................................................. 92

F. Sampel................................................. 93

G. Teknik Pengumpulan Data...................................... 94

H. Teknik Analisis Data.......................................... 96

1. Statistik Deskriptif..................................... 96

2. Manipulation Check.................................. 97

G. Uji Kualitas Data...................................... 98

2. Pilot Test............................................. 98

3. Uji Validitas........................................ 99

4. Uji Reabilitas....................................... 100

H. Uji Asumsi ANOVA.................................... 101

5. Uji Normalitas....................................... 101 
6. Uji Homogenitas Varians.................................... 101

7. Random Sampling...................................... 102

I. Pengujian Hipotesis......................................... 102

8. ANOVA.......................................... 102

9. Uji Post Hoc......................................... 113

10. Koefisien Determinasi.................................. 116

BAB IV. HASIL PENELITIAN DAN PEMBAHASAN ................. 117

A Deskripsi Data Penelitian.................................... 117

B Hasil Pilot Test............................................... 122

C Statistik Deskriptif Variabel................................. 123

1. Senjangan Anggaran.................................... 123

2. Asimetri Informasi....................................... 127

3. Orientasi Etika....................................... 128

D. Uji Validitas dan Reabilitas................................. 135

1. Kuesioner Orientasi Etika............................... 135

2. Instrumen Perlakuan Asimetri Informasi..................... 137

E. Uji Asumsi ANOVA........................................ 138

1. Uji Normalitas..................................... 138

2. Uji Homogenitas Varians................................ 139

F. Uji Hipotesis................................................ 140

1. Pengaruh Asimetri Informasi terhadap Senjangan Anggaran..... 140

a. Pengujian Hipotesis................................. 140

b. Koefisien Determinasi.................................. 146

2. Pengaruh Tingkatan Relativisme pada Hubungan Asimetri Informasi terhadap Senjangan Anggaran.............. 147

3. Pengaruh Tingkatan Idealisme pada Hubungan Asimetri Informasi terhadap Senjangan Anggaran.

4. Pengaruh Tingkatan Orientasi Etika pada Hubungan Asimetri Informasi terhadap Senjangan Anggaran ............ 153

G. Pembahasan.............................................. 158 
1. Pengaruh Asimetri Informasi terhadap Senjangan Anggaran......

2. Pengaruh Orientasi Etika pada Hubungan Asimetri Informasi terhadap Senjangan Anggaran........................... 161

BAB V. KESIMPULAN DAN SARAN ............................. 167

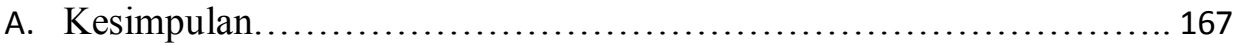

B. Kontribusi Penelitian.......................................... 168

C. Keterbatasan Penelitian............................................ 169

D. Saran .............................................................. 170

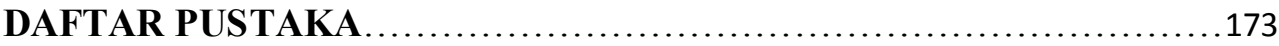

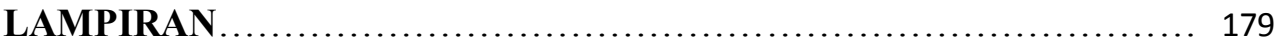




\section{DAFTAR TABEL}

Tabel

Halaman

1. Desain Eksperimen Pengaruh Asimetri Informasi terhadap Senjangan Anggaran................................... 81

2. Desain Eksperimen Pengaruh Asimetri Informasi dan Relativisme terhadap Senjangan Anggaran...................82

3. Desain Eksperimen Pengaruh Asimetri Informasi dan Idealisme terhadap Senjangan Anggaran......................82

4. Desain Eksperimen Pengaruh Asimetri Informasi dan Orientasi Etika terhadap Senjangan Anggaran.................8 82

5. Kisi-Kisi Variabel Penelitian...............................94

6. Skema Data Eksperimen Berdasarkan Tingkatan Asimetri Informasi.................................................103

7. ANOVA untuk Klasifikasi Satu Arah Fixed Effect Model.......106

8. ANOVA untuk Klasifikasi Dua Arah dengan Desain Faktorial dan Fixed Effect Model......................................... 111

9. Deskripsi Data Penelitian................................. 117

10. Statistik Deskriptif Data.................................. 118

11. Statistik Deskriptif Umur................................... 119

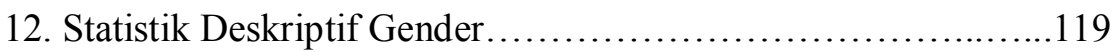

13. Statistik Deskriptif Angkatan................................120

14. Statistik Deskriptif IPK................................... 120

15. Statistik Deskriptif Mata Kuliah yang Sudah Lulus...............121

16. Statistik Deskriptif Program Studi.............................121

17. Deskriptif Variabel Senjangan Anggaran..........................123

18. Distribusi Frekuensi Variabel Senjangan Anggaran..............125

19. Kategori Kecenderungan Senjangan Anggaran..................126

20. Skor Asimetri Informasi...................................127

21. Distribusi Frekuensi Variabel Asimetri Informasi...............127

22. Skor Orientasi Etika.......................................130

23. Mean dan Median Orientasi Etika............................ 130

24. Distribusi Frekuensi Orientasi Etika.........................131

25. Distribusi Frekuensi Relativisme.............................133

26. Distribusi Frekuensi Idealisme..................................134

27. Pearson Correlation Relativisme..............................135

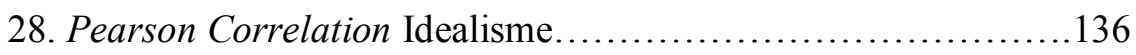

29. Uji Reabilitas Relativisme dan Idealisme......................137

30. Hasil Uji Normalitas Senjangan Anggaran pada Tingkatan 
Asimetri Informasi...............................................138

31. Uji Normalitas Variabel Orientasi Etika............................139

32. Uji Homogenitas Varians........................................139

33. Test of Between-Subjects Effects Asimetri Informasi..................141

34. Tabel Senjangan Anggaran Berdasarkan Asimetri Informasi.........142

35. Uji Post Hoc Asimetri Informasi....................................143

36. Kategori Senjangan Anggaran pada Tingkatan Asimetri

Informasi....................................................145

37. Senjangan Anggaran Berdasarkan Asimetri Informasi

dan Relativisme.............................................147

38. Test of Between-Subjects Effects Asimetri Informasi dan Relativisme............................................ 148

39. Senjangan Anggaran Berdasarkan Asimetri Informasi dan Idealisme...............................................151

40. Test of Between-Subjects Effects Asimetri Informasi dan Idealisme............................................. 151

41. Senjangan Anggaran Berdasarkan Orinetasi Etika dan Asimetri Informasi......................................... 154

42. Test of Between-Subjects Effects Asimetri Informasi dan Orientasi Etika...........................................155

43. Uji Post Hoc Orientasi Etika........................................156 


\section{DAFTAR GAMBAR}

\begin{tabular}{|c|c|c|}
\hline \multicolumn{2}{|c|}{ Gambar } & Halaman \\
\hline \multicolumn{2}{|c|}{1 Paradigma Penelitian. } & $\ldots 79$ \\
\hline 2 & Histogram Distribusi Frekuensi Senjangan Anggaran. & $\ldots 125$ \\
\hline 3 & Histogram Distribusi Frekuensi Asimetri Informasi... &. .128 \\
\hline 4 & Histogram Distribusi Frekuensi Variabel Relativisme. & $\ldots 134$ \\
\hline 5 & Histogram Distribusi Frekuensi Variabel Idealisme... & $\ldots .135$ \\
\hline 6 & Grafik Senjangan Anggaran pada Tingkatan Asimetri & \\
\hline & Informasi.......................................... & .144 \\
\hline 7 & Grafik Senjangan Anggaran Berdasarkan Relativisme. & $\ldots 150$ \\
\hline 8 & Grafik Senjangan Anggaran Berdasarkan Idealisme.... & $\ldots .153$ \\
\hline 9 & Grafik Senjangan Anggaran Exceptionist, Absolutist, & \\
\hline & Subjectivist, dan Situationist............................. & ..157 \\
\hline
\end{tabular}




\section{DAFTAR LAMPIRAN}

Lampiran Halaman

1. Instrumen Penelitian........................................179

2. Statistik Deskriptif Partisipan.................................198

3. Uji Reabilitas dan Validitas Variabel.........................209

4. Uji Asumsi ANOVA........................................214

5. Uji Hipotesis............................................218 


\section{BAB I}

\section{PENDAHULUAN}

\section{A. Latar Belakang Masalah}

Setiap perusahaan pasti memiliki tujuan dan sasaran jangka panjang yang mengarah pada kemajuan perusahaan. Pencapaian tujuan dan sasaran jangka panjang tersebut, diperlukan perencanaan yang berisi langkah-langkah strategis. Perencanaan tersebut diturunkan menjadi perencanaan dalam jangka pendek yang lebih rinci. Perencanaan jangka pendek akan diterjemahkan ke dalam bentuk anggaran. Menurut Arfan (2011), anggaran merupakan suatu perencanaan manajerial yang dituangkan dalam istilah-istilah keuangan dan angka. Dalam anggaran, perusahaan akan menentukan sasaran yang ingin dicapai dalam jangka pendek yang nantinya akan mengarah pada tercapainya tujuan dan sasaran jangka panjang perusahaan.

Anggaran yang dibuat akan dijadikan pedoman bagi manajer untuk melaksanakan kegiatan perusahaan yang sudah direncanakan dalam anggaran. Dalam menjalankan kegiatan perusahaan maka diperlukan pengendalian agar kegiatan yang dilaksanakan manajer sesuai dengan yang direncanakan, yaitu dengan menggunakan anggaran. Jadi, anggaran juga merupakan sistem pengendalian manajemen yang berfungsi sebagai alat pengendalian jangka pendek (biasanya dibuat untuk jangka waktu satu tahun) agar manajer dapat melaksanakan kegiatan organisasi secara efektif dan efisien (Anthony dan Govindarajan, 2005). 
Anggaran berpengaruh pada kinerja perusahaan karena anggaran adalah alat untuk mencapai tujuan dan sasaran perusahaan baik secara jangka panjang maupun jangka pendek. Tercapainya tujuan dan sasaran perusahaan akan membuat perusahaan akan semakin maju. Oleh karena itu, anggaran yang dibuat harus efisien dan efektif. Anggaran yang tidak efisien akan berdampak pada pemborosan biaya yang tentu ini tidak diinginkan oleh perusahaan, sedangkan anggaran yang tidak efektif akan membuat anggaran tidak bisa mencapai tujuan perusahaan. Selain itu, anggaran yang diajukan manajer bawah harus menunjukkan kinerja optimal dari manajer bawah karena anggaran yang dibuat tanpa adanya usaha yang optimal akan menghilangkan kesempatan untuk memperoleh laba optimal.

Menurut Anthony \& Govindarajan (2005), proses penyusunan anggaran bisa bersifat dari "atas-ke-bawah" atau dari "bawah-ke-atas", yang terakhir disebut penganggaran partisipatif. Pada penyusunan anggaran dari atas ke bawah, manajer senior menetapkan anggaran untuk tingkat manajer yang lebih rendah, sedangkan pada penyusunan anggaran dari bawah ke atas (penganggaran partisipatif), manajer yang lebih bawah ikut berpartisipasi dalam proses penyusunan anggaran. Dalam partisipasi anggaran, manajer bawah terlibat dan memiliki pengaruh dalam menentukan anggaran.

Penganggaran partisipatif memiliki keunggulan, yaitu manajer yang lebih rendah ikut berpartisipasi dalam proses penyusunan anggaran dimana manajer tersebut memiliki pengetahuan dan informasi relevan yang lebih baik mengenai unit tanggungjawabnya daripada manajer atas sehingga diharapkan dengan 
kontribusi mereka dalam penyusunan anggaran dapat menciptakan suatu anggaran yang akurat sehingga dapat mengoptimalkan kinerja perusahaan. Namun, penganggaran partisipatif juga memiliki kelemahan. Dalam partisipasi anggaran, manajer bawah terlibat dan memiliki pengaruh dalam menentukan anggaran sehingga jika terdapat perbedaan informasi antara manajer bawah dan manajer atas, manajer bawah dapat memanfaatkan perbedaan informasi tersebut untuk melakukan senjangan anggaran.

Menurut Harrell \& Harrison (1994), adanya kesempatan merupakan salah satu syarat yang membuat seorang manajer tidak memenuhi tanggungjawabnya kepada perusahaan yang dalam hal ini dengan menciptakan senjangan anggaran. Partisipasi anggaran merupakan kesempatan bagi manajer bawah untuk membuat senjangan anggaran. Jika tidak ada partisipasi anggaran maka manajer bawah akan sulit untuk membuat senjangan anggaran karena anggaran akan ditentukan oleh manajer atas. Berdasarkan hal tersebut, peneliti mendesain penelitian eksperimental pada penganggaran partisipatif. Penelitian eksperimental dilakukan agar hasil penelitian yang didapat lebih objektif (Faria \& Silva, 2013) karena peneliti dapat mengamati secara langsung tindakan yang dilakukan partisipan.

Senjangan anggaran adalah perbedaan antara jumlah anggaran yang diajukan dengan estimasi terbaik (Anthony \& Govindarajan, 2005). Manajer bawah akan mengajukan anggaran dibawah estimasi kemampuan terbaiknya. Seringkali manajer bawah memperendah kemampuan kinerjanya dengan meninggikan kebutuhan sumber-sumber daya yang dialokasikan dalam anggaran 
atau meninggikan pengeluaran atau memperendah pendapatan dalam menyusun anggaran (Schiff \& Lewin, 1970; Kren, 2003; Lukka, 1988).

Senjangan anggaran menjadi masalah bagi perusahaan. Senjangan anggaran dapat mengakibatkan pengalokasian sumber-sumber daya yang tidak efisien, anggaran yang ditetapkan menjadi tidak efektif, dan fungsi anggaran sebagai alat menilai kinerja manajer bawah menjadi tidak berfungsi dengan baik karena anggaran yang ditetapkan tidak mencerminkan kemampuan sebenarnya dari manajer bawah.

Selain itu, jika suatu anggaran yang ditetapkan terdapat senjangan anggaran, maka akan mempengaruhi anggaran untuk tahun berikutnya. Biasanya, anggaran yang sedari awal sudah terdapat senjangan anggaran maka untuk anggaran tahun berikutnya akan terdapat senjangan anggaran yang semakin besar. Hal tersebut didukung oleh penelitian yang dilakukan oleh Stevens (2002) yang meneliti mengenai peningkatan senjangan anggaran seiring dengan tahun periode anggaran. Hal tersebut karena manajer bawah akan menetapkan anggaran tahun berikutnya berdasarkan anggaran yang sudah terdapat senjangan anggaran dimana kinerja anggaran tersebut di bawah kemampuan kinerja manajer bawah.

Anggaran yang terdapat senjangan anggaran mencerminkan kinerja anggaran di bawah kemampuan kinerja manajer bawah, jika anggaran tersebut digunakan untuk menyusun anggaran selanjutnya maka anggaran periode selanjutnya juga akan berada di bawah kemampuan kinerja manajer bawah, sedangkan kemampuan kinerja manajer bawah semakin meningkat seiring dengan pengalaman kinerjanya. 
Jika senjangan anggaran terus terjadi maka akan membuat perusahaan memiliki kinerja yang tidak optimal. Hal tersebut akan membuat perusahaan kurang bisa bersaing dengan perusahaan kompetitor. Jika hal tersebut terjadi bukan tidak mungkin perusahaan akan mengalami kerugian karena kehilangan pelanggan. Perusahaan yang mengalami kerugian tentu tidak akan dilirik oleh investor. Jika demikian, perusahaan akan kehilangan modal untuk mengembangkan perusahaan. Mengingat dampak buruk yang diakibatkan oleh adanya senjangan anggaran maka peneliti bermaksud meneliti mengenai senjangan anggaran dengan menggunakan variabel-variabel yang diperkirakan dapat mempengaruhi senjangan anggaran. Hal tersebut bertujuan untuk mengetahui faktor-faktor apa saja yang dapat mempengaruhi senjangan anggaran sehingga faktor-faktor tersebut dapat dikurangi atau diminimalisasi agar tidak menimbulkan senjangan anggaran.

Peneliti akan melakukan eksperimen untuk melihat kecenderungan manajer bawah dalam melakukan senjangan anggaran. Kecenderungan untuk membuat senjangan anggaran akan dilihat berdasarkan rata-rata nilai senjangan anggaran yang dibuat oleh manajer bawah.

Manajer yang lebih rendah melakukan senjangan anggaran untuk kepentingan pribadinya. Hal ini sesuai dengan konsep teori agensi. Dalam teori agensi, agen (manajer yang lebih rendah) dan principal (manajemen puncak) memiliki kepentingan yang berbeda. Principal memiliki kepentingan untuk terus mengembangkan perusahaannya, sedangkan agen memiliki kepentingan pribadinya sendiri (Anthony \& Govindarajan, 2005). 
Dalam konsep teori agensi, manajer atas memperkerjakan manajer bawah untuk mengoperasikan perusahaan dengan manajer atas mendelegasikan wewenang atau tanggungjawab kepada manajer bawah. Pendelegasian wewenang ini memunculkan kondisi asimetri informasi dimana manajer bawah lebih mengetahui informasi lokal di unit tanggungjawabnya daripada manajer atas, juga manajer atas akan sulit untuk mengawasi manajer bawah terkait tindakan yang dilakukannya.

Asimetri informasi sering terjadi di perusahaan terutama perusahaan yang memiliki struktur kepengurusan/unit tanggungjawab yang kompleks (Young \& Shields, 1993). Adanya asimetri informasi ini memunculkan adanya kebijakan penganggaran partisipatif. Dengan kebijakan penganggaran partisipatif, manajer bawah diharapkan dapat memberikan masukan sehingga terjadi pertukaran informasi terkait penyusunan anggaran mengingat penetapan anggaran tidak dapat dilakukan secara akurat ketika manajemen tingkat bawah memiliki informasi yang lebih baik tentang faktor-faktor yang mempengaruhi kinerjanya dibandingkan manajemen tingkat atas. Walaupun begitu, adanya asimetri informasi dimanfaatkan oleh manajer bawah untuk menciptakan senjangan anggaran karena perbedaan informasi yang dimiliki antara manajer atas dengan manajer bawah. Berdasarkan pernyataan tersebut, peneliti bermaksud menguji pengaruh adanya asimetri informasi terhadap senjangan anggaran pada penganggaran partisipatif dengan pertimbangan bahwa asimetri informasi sering terjadi di perusahaan terutama di perusahaan besar. 
Menurut Herrel \& Harrison (1994), faktor yang membuat manajer bawah tidak memenuhi tanggungjawabnya kepada perusahaan tidak hanya adanya kesempatan untuk melakukan tindakan yang menyimpang, tetapi juga faktor insentif yang memotivasi untuk melakukan tindakan tersebut. Oleh karena itu, peneliti memasukkan insentif untuk memotivasi manajer bawah dengan memanfaatkan asimetri informasi untuk membuat senjangan anggaran guna memperoleh keuntungan pribadi. Hal ini didukung oleh pernyataan Douglas \& Wier (2000) yang menyatakan bahwa manajer bawah akan memanfaatkan asimetri informasi untuk melakukan senjangan anggaran jika terdapat insentif. Insentif akan diberikan pada masing-masing tingkatan asimetri informasi karena insentif bukan variabel yang diuji dalam penelitian ini.

Peneliti mendesain penelitian eksperimental yang membagi kondisi asimetri informasi menjadi tiga kategori, yaitu tidak ada asimetri informasi, asimetri informasi rendah, dan asimetri informasi tinggi. Hal ini untuk membedakan pengaruhnya terhadap senjangan anggaran. Pengaruh tingkatan asimetri informasi dilihat berdasarkan rata-rata nilai senjangan anggaran yang dibuat oleh manajer bawah.

Pada kondisi tidak ada asimetri informasi, manajer bawah tidak akan memiliki kesempatan untuk melakukan senjangan anggaran karena informasi lokal diketahui oleh manajer atas sehingga memiliki kecenderungan untuk melakukan senjangan anggaran yang sangat kecil. Karena memiliki kecenderungan yang sangat kecil maka pada kelompok tidak ada asimetri informasi akan memiliki rata-rata nilai senjangan anggaran yang sangat rendah. 
Sebaliknya, pada kondisi asimetri informasi rendah, manajer bawah memiliki kesempatan walaupun kecil untuk melakukan senjangan anggaran. Hal ini karena tidak semua informasi lokal diketahui oleh manajer atas sehingga manajer bawah dapat memanfaatkan informasi yang tidak diketahui manajer atas untuk mendapatkan insentif. Pada asimetri informasi rendah, ada kecenderungan manajer bawah untuk melakukan senjangan anggaran, namun masih tergolong rendah karena kesempatan yang dimiliki rendah. Karena memiliki kecenderungan untuk membuat senjangan anggaran yang rendah maka pada kelompok asimetri informasi rendah akan memiliki rata-rata nilai senjangan anggaran yang rendah.

Pada kondisi asimetri informasi tinggi manajer bawah akan memiliki kesempatan yang besar untuk melakukan senjangan anggaran karena informasi lokal tidak diketahui oleh manajer atas sehingga manajer bawah dapat memanfaatkan informasi yang dimilikinya tersebut untuk mendapatkan insentif. Manajer bawah akan cenderung membuat senjangan anggaran pada kondisi asimetri informasi mengingat adanya kesempatan yang besar. Karena memiliki kecenderungan yang tinggi untuk membuat senjangan anggaran maka pada kelompok asimetri informasi tinggi akan memiliki rata-rata nilai senjangan anggaran yang tinggi. Berdasarkan pernyataan di atas maka diduga pada kelompok tingkatan asimetri informasi terdapat perbedaan rata-rata nilai senjangan anggaran yang artinya ada pengaruh tingkatan asimetri informasi terhadap senjangan anggaran.

Ada kalanya manajer bawah yang dihadapkan pada asimetri informasi tinggi tidak melakukan senjangan anggaran walau dengan membuat senjangan 
anggaran dapat memperoleh insentif yang besar. Salah satu penyebabnya adalah faktor individu. Hal tersebut didukung oleh pendapat Dunk \& Perera (1996) yang menyatakan bahwa penyebab senjangan anggaran tidak hanya asimetri informasi saja, tetapi juga faktor personal. Oleh karena itu, penulis akan menginteraksikan asimetri informasi dengan variabel individu sebagai variabel moderating. Variabel moderating yang digunakan dalam penelitian ini adalah orientasi etika. Penulis memilih orientasi etika karena menurut Forsyth (1992), suatu hal yang menentukan dari suatu perilaku seseorang sebagai jawaban dari masalah etika adalah filosofi moral pribadinya. Hal tersebut karena orientasi etika dapat menjelaskan kenapa individu menilai etis atau tidak etis atas suatu tindakan.

Orientasi etika merupakan cara pandang individu atas suatu masalah etis yang kemudian mempengaruhi penilaiannya terhadap masalah etis tersebut, lalu akan mempengaruhi motivasi untuk berbuat dan akan diwujudkan dalam perbuatan (Shaub, 1993). Orientasi etika terkait dengan kemampuan individu untuk mengevaluasi dan mempertimbangkan nilai etika dalam suatu kasus. Orientasi etika menunjukkan pandangan yang diadopsi individu ketika menghadapi situasi yang membutuhkan pemecahan terkait dengan etika atau dilema etika, dimana individu harus mengambil keputusan antara etis atau tidaknya suatu perilaku dan melakukan tindakan atas penilaian tersebut.

Forsyth (1980) membagi orientasi etika menjadi dua tipe. Orientasi etika yang pertama adalah relativisme yang berkaitan dengan keyakinan terhadap aturan moral secara umum dalam menilai etis atau tidaknya suatu tindakan. Individu dapat memiliki relativisme tinggi atau rendah. Individu yang memiliki relativisme 
tinggi akan menghiraukan aturan moral secara umum untuk menilai etis atau tidaknya tindakan. Individu tersebut akan menilai etis atau tidaknya suatu perilaku berdasarkan pertimbangan-pertimbangan personal. Hal tersebut karena relativist menganggap bahwa terdapat aturan moral yang berbeda-beda antara kelompok, masyarakat, atau organisasi satu dengan yang lain sehingga hal tersebut memunculkan perbedaan pendapat mengenai aturan moral. Oleh karena itu, relativist menganggap bahwa akan lebih baik jika aturan moral didasarkan pada pertimbangan individu. Pemikiran individu akan menilai etis atau tidaknya suatu tindakan dengan mempertimbangkan situasi yang melatarbelakangi tindakan yang akan dilakukan tersebut. Oleh karena itu, jika aturan moral secara umum menyatakan suatu perilaku tidak etis maka bagi individu yang memiliki relativisme tinggi belum tentu berpendapat demikian. Sebaliknya, individu yang memiliki relativisme rendah meyakini aturan moral secara umum dalam menilai etis atau tidaknya suatu tindakan. Hal tersebut karena individu yang memiliki relativisme rendah meyakini bahwa aturan moral secara umum harus diterapkan secara konsisten.

Peneliti membagi masing-masing tingkatan asimetri informasi berdasarkan tinggi rendahnya orientasi etika. Manajer bawah yang memiliki relativisme tinggi akan memiliki kecenderungan yang lebih tinggi dalam menilai senjangan anggaran termasuk tindakan etis. Hal ini dikarenakan individu tersebut menilai etis atau tidaknya senjangan anggaran berdasarkan pertimbangan personal bukan dari aturan moral yang berlaku secara umum yang menyatakan senjangan anggaran termasuk tindakan tidak etis. Sebaliknya, manajer bawah yang memiliki 
relativisme rendah lebih cenderung untuk menilai senjangan anggaran termasuk tindakan tidak etis karena meyakini aturan moral secara umum yang menyatakan senjangan anggaran termasuk tindakan tidak etis.

Jika dihadapkan pada kondisi asimetri informasi maka manajer bawah yang memiliki relativisme tinggi akan memiliki kecenderungan yang lebih tinggi untuk melakukan senjangan anggaran karena individu tersebut menilai senjangan anggaran termasuk tindakan etis. Hal tersebut didukung oleh adanya kesempatan untuk membuat senjangan anggaran pada kondisi asimetri informasi. Semakin besar kesempatan untuk memanfaatkan asimetri informasi guna mendapatkan insentif maka semakin tinggi kecenderungan manajer bawah yang memiliki relativisme tinggi untuk melakukan senjangan anggaran. Karena memiliki kecenderungan untuk membuat senjangan anggaran yang tinggi maka pada kelompok relativisme tinggi akan memiliki rata-rata nilai senjangan anggaran yang tinggi.

Manajer bawah yang memiliki relativisme rendah akan memiliki kecenderungan yang lebih rendah untuk melakukan senjangan anggaran walaupun dihadapkan pada kondisi asimetri informasi tinggi sekalipun. Individu tersebut tidak akan memanfaatkan asimetri informasi untuk mendapatkan insentif. Hal ini karena individu tersebut menilai senjangan anggaran termasuk tindakan tidak etis sehingga akan menghindari senjangan anggaran. Individu yang memiliki relativisme rendah menganggap senjangan anggaran bertentangan dengan aturan moral secara umum. Karena memiliki kecenderungan yang rendah untuk membuat senjangan anggaran maka pada kelompok relativisme rendah akan 
memiliki rata-rata nilai senjangan anggaran yang rendah. Berdasarkan pernyataan di atas, tingkat relativisme diduga dapat memoderasi pengaruh asimetri informasi terhadap senjangan anggaran pada penganggaran partisipatif dimana manajer bawah yang memiliki relativisme tinggi akan memiliki rata-rata nilai senjangan anggaran yang lebih tinggi daripada manajer bawah yang memiliki relativisme rendah.

Orientasi etika yang kedua adalah idealisme. Idealisme berkaitan dengan keyakinan individu terkait konsekuensi atau dampak yang ditimbulkan dari suatu tindakan untuk mengkategorikannya menjadi tindakan etis atau tidak. Sama seperti relativisme, idealisme pada individu dapat tinggi atau rendah. Individu yang memiliki idealisme tinggi meyakini bahwa suatu tindakan dikatakan etis jika tindakan tersebut tidak akan merugikan pihak lain, sedangkan tindakan yang tidak etis akan merugikan pihak lain. Sebaliknya, individu yang memiliki idealisme rendah meyakini bahwa suatu tindakan dapat dikatakan etis walaupun dapat merugikan pihak lain karena individu tersebut meyakini bahwa tindakan tersebut di sisi lain dapat memberikan dampak positif.

Peneliti membagi idealisme menjadi dua kelompok berdasarkan tingkatannya, yaitu tinggi dan rendah. Manajer bawah yang memiliki idealisme tinggi akan memiliki kecenderungan yang lebih tinggi dalam menilai senjangan anggaran termasuk perilaku tidak etis. Hal tersebut dikarenakan manajer bawah yang memiliki idealisme tinggi meyakini bahwa senjangan anggaran dapat merugikan perusahaan sehingga senjangan anggaran perlu dihindari. Dengan demikian, manajer bawah yang memiliki idealisme tinggi akan memiliki 
kecenderungan yang lebih rendah untuk melakukan senjangan anggaran, walaupun dihadapkan pada kondisi asimetri informasi tinggi sekalipun. Individu yang memiliki idealisme tinggi tidak akan memanfaatkan asimetri informasi untuk mendapatkan insentif. Oleh karena memiliki kecenderungan yang lebih rendah untuk membuat senjangan anggaran maka pada kelompok idealisme tinggi akan memiliki rata-rata nilai senjangan anggaran yang lebih rendah.

Sebaliknya, manajer bawah yang memiliki idealisme rendah akan memiliki kecenderungan yang lebih rendah dalam menilai senjangan anggaran termasuk tindakan tidak etis. Hal ini karena individu tersebut menganggap bahwa senjangan anggaran termasuk tindakan etis walaupun dapat merugikan perusahaan. Dengan demikian, manajer bawah yang memiliki idealisme rendah akan memiliki kecenderungan yang lebih tinggi untuk melakukan senjangan anggaran jika dihadapkan pada kondisi asimetri informasi. Semakin tinggi tingkat asimetri informasi maka kecenderungan untuk melakukan senjangan anggaran akan semakin tinggi bagi manajer bawah yang memiliki idealisme rendah. Oleh karena manajer bawah memiliki kecenderungan untuk membuat senjangan anggaran yang lebih tinggi maka pada kelompok idealisme rendah akan memiliki rata-rata nilai senjangan anggaran yang lebih tinggi. Berdasarkan pernyataan di atas, tingkat idealisme diduga dapat memoderasi pengaruh asimetri informasi terhadap senjangan anggaran pada penganggaran partisipatif dimana manajer bawah yang memiliki idealisme tinggi akan memiliki rata-rata nilai senjangan anggaran yang lebih rendah daripada manajer bawah yang memiliki idealisme rendah. 
Gabungan tingkatan relativisme dan idealisme akan mempengaruhi penilaian etis manajer bawah untuk melakukan senjangan anggaran. Forsyth (1980) membagi orientasi etika menjadi empat tipe, yaitu situationist, absolutist, subjectivist, dan exceptionist. Berdasarkan hal tersebut maka peneliti membagi orientasi etika menjadi empat kelompok.

Situationist merupakan individu yang memiliki relativisme dan idealisme tinggi. Situationist melakukan penilaian etis berdasarkan pertimbangan personal dan meyakini bahwa suatu tindakan yang akan dilakukan tidak boleh merugikan pihak lain. Situationist memiliki kemungkinan untuk menilai senjangan anggaran termasuk tindakan etis atau tidak etis sehingga penilaian etis yang dilakukan tergantung pada situasi yang ada. Dengan demikian, situationist memiliki kemungkinan untuk melakukan senjangan anggaran atau tidak melakukannya.

Exceptionist merupakan individu yang memiliki relativisme rendah dan idealisme rendah. Exceptionist menilai etis atau tidaknya suatu tindakan berdasarkan aturan moral secara umum, namun exceptionist dapat melakukan pengecualian dengan menggunakan pertimbangan personal untuk menilai etis atau tidaknya tindakan karena exceptionist meyakini bahwa suatu tindakan boleh dilakukan walaupun dapat berdampak negatif. Hal tersebut membuat exceptionist memiliki kemungkinan untuk melakukan senjangan anggaran atau tidak melakukannya.

Kecenderungan manajer bawah untuk membuat senjangan anggaran dilihat berdasarkan rata-rata nilai senjangan anggaran yang dibuat manajer bawah pada masing-masing kelompok orientasi etika. Oleh karena situationist dan exceptionist 
memiliki kemungkinan untuk melakukan atau tidak melakukan senjangan anggaran maka rata-rata nilai senjangan anggaran pada kelompok situationist dan exceptionist tidak terlalu rendah ataupun terlalu tinggi.

Absolutist merupakan individu yang memiliki relativisme rendah dan idealisme tinggi. Absolutist melakukan penilaian etis berdasarkan aturan moral secara umum dan meyakini bahwa suatu tindakan yang akan dilakukan tidak boleh merugikan pihak lain. Karena keyakinannya tersebut maka absolutist akan menghindari senjangan anggaran karena menganggap senjangan anggaran termasuk tindakan tidak etis. Absolutist tidak akan memanfaatkan adanya asimetri informasi dengan membuat senjangan anggaran guna mendapatkan insentif. Oleh karena memiliki kecenderungan untuk membuat senjangan anggaran yang rendah maka pada kelompok absolutist akan memiliki rata-rata nilai senjangan anggaran yang rendah. Dibandingkan dengan situationist, exceptionist, dan subjectivist, absolutist memiliki kecenderungan yang paling rendah untuk melakukan senjangan anggaran pada kondisi asimetri informasi sehingga akan memiliki ratarata nilai senjangan anggaran yang paling rendah. Walaupun asimetri informasi meningkat, kecenderungan untuk melakukan senjangan anggaran akan tetap rendah bagi absolutist.

Subjectivist merupakan individu yang memiliki relativisme tinggi dan idealisme rendah. Subjectivist melakukan penilaian etis berdasarkan pertimbangan personal dan meyakini bahwa suatu tindakan boleh dilakukan walaupun berdampak negatif. Karena penilaiannya tersebut, subjectivist memiliki kecenderungan tinggi untuk melakukan senjangan anggaran karena menilai 
senjangan anggaran termasuk tindakan yang etis. Dibandingkan dengan absolutist, situationist, dan exceptionist, subjectivist memiliki kecenderungan yang paling tinggi untuk melakukan senjangan anggaran pada tingkatan asimetri informasi. Kecenderungan subjectivist untuk melakukan senjangan anggaran akan semakin tinggi jika asimetri informasi meningkat. Oleh karena manajer bawah memiliki kecenderungan untuk membuat senjangan anggaran yang tinggi maka pada kelompok subjectivist akan memiliki rata-rata nilai senjangan anggaran yang tinggi. Berdasarkan pernyataan di atas, tingkat orientasi etika diduga dapat memoderasi pengaruh asimetri informasi terhadap senjangan anggaran pada penganggaran partisipatif berdasarkan rata-rata nilai pada masing-masing kelompok orientasi etika.

Peneliti menggunakan mahasiswa Akuntansi dan Pendidikan Akuntansi S1 Universitas Negeri Yogyakarta yang sudah lulus mata kuliah Akuntansi Manajemen atau Sistem Pengendalian Manajemen atau Penganggaran untuk dijadikan partisipan dalam penelitian eksperimental dengan pertimbangan bahwa mahasiswa S1 yang sudah lulus mata kuliah tersebut dianggap sudah memiliki pengetahuan perihal penyusunan anggaran dan mengerti mengenai senjangan anggaran sehingga dinilai mampu untuk berperan sebagai manajer bawah dalam penelitian ini.

Berdasarkan uraian dari latar belakang di atas, penelitian ini bermaksud menguji pengaruh asimetri informasi terhadap senjangan anggaran pada penganggaran partisipatif dengan orientasi etika sebagai variabel moderating. Oleh karena itu, peneliti mengambil judul "Pengaruh Asimetri Informasi terhadap 
Senjangan Anggaran pada Penganggaran Partisipatif dengan Orientasi Etika Sebagai Variabel Moderating”.

\section{B. Identifikasi Masalah}

Identifikasi masalah dalam penelitian ini sesuai dengan latar belakang masalah di atas adalah sebagai berikut :

1. Partisipasi anggaran sering dimanfaatkan manajer bawah untuk melakukan senjangan anggaran karena manajer bawah terlibat dan memiliki pengaruh terhadap penetapan anggaran.

2. Adanya asimetri informasi akan membuat manajer bawah memanfaatkan asimetri informasi tersebut untuk melakukan senjangan anggaran pada penganggaran partisipatif.

3. Relativisme tinggi membuat manajer bawah melakukan senjangan anggaran pada penganggaran partisipatif dalam kondisi asimetri informasi karena manajer bawah menganggap senjangan anggaran termasuk tindakan etis.

4. Idealisme rendah membuat manajer bawah melakukan senjangan anggaran pada pengganggaran partisipatif dalam kondisi asimetri informasi karena manajer bawah menganggap senjangan anggaran termasuk tindakan etis.

5. Subjectivist melakukan senjangan anggaran karena mengganggap senjangan anggaran termasuk tindakan etis. 


\section{Pembatasan Masalah}

Ada banyak faktor yang dapat mempengaruhi senjangan anggaran pada penganggaran partisipatif, namun dalam penelitian ini, peneliti hanya akan menguji pengaruh asimetri informasi terhadap senjangan anggaran (budgetary slack) pada penganggaran partisipatif dengan dua karakteristik orientasi etika manajer bawah, yaitu relativisme dan idealisme sebagai variabel moderating, melalui penelitian eksperimental.

\section{Rumusan Masalah}

1. Apakah tingkatan asimetri informasi berpengaruh terhadap senjangan anggaran?

2. Apakah tingkatan relativisme memoderasi pengaruh asimetri informasi terhadap senjangan anggaran?

3. Apakah tingkatan idealisme memoderasi pengaruh asimetri informasi terhadap senjangan anggaran?

4. Apakah orientasi etika memoderasi pengaruh asimetri informasi terhadap senjangan anggaran?

\section{E. Tujuan Penelitian}

Tujuan yang ingin dicapai dari pelaksanaan penelitian ini adalah untuk:

1. Mengetahui apakah asimetri informasi berpengaruh terhadap senjangan anggaran.

2. Mengetahui apakah tingkatan relativisme memoderasi pengaruh asimetri informasi terhadap senjangan anggaran. 
3. Mengetahui apakah tingkatan idealisme memoderasi pengaruh asimetri informasi terhadap senjangan anggaran.

4. Mengetahui apakah orientasi etika memoderasi pengaruh asimetri informasi terhadap senjangan anggaran.

\section{F. Manfaat Penelitian}

Manfaat yang diharapkan didapat dari penelitian ini adalah:

1. Manfaat Teoritis

Penelitian ini diharapkan dapat memberikan bukti empiris terkait penelitian mengenai pengaruh tingkat asimetri informasi terhadap senjangan anggaran pada penganggaran partisipatif dengan orientasi etika sebagai variabel moderating.

2. Manfaat Praktis

a. Bagi Peneliti

Dapat meningkatkan pengetahuan dan pemahaman peneliti tentang pengaruh asimetri informasi terhadap senjangan anggaran pada penganggaran partisipatif dengan orientasi etika manajer bawah sebagai variabel moderating.

b. Bagi Pembaca

Hasil penelitian ini diharapkan dapat menambah wawasan pembaca mengenai pengaruh yang ditimbulkan dari tingkatan asimetri informasi terhadap senjangan anggaran (budgetary slack) pada penganggaran partisipatif dengan orientasi etika manajer bawah sebagai variabel moderating. 
c. Bagi Peneliti Selanjutnya

Hasil penelitian ini diharapkan dapat dijadikan tambahan referensi bagi peneliti selanjutnya yang meneliti mengenai senjangan anggaran yang dikaitkan dengan variabel asimetri informasi dan orientasi etika. 


\section{BAB II}

\section{KAJIAN TEORI DAN PENELITIAN YANG RELEVAN}

\section{A. Kajian Teori}

\section{Teori Agensi}

Penjelasan konsep senjangan anggaran dapat dimulai dari konsep teori agensi. Praktik senjangan anggaran dalam perspektif teori agensi dipengaruhi oleh adanya konflik kepentingan antara agen (manajer) dengan principal. Menurut Anthony \& Govindarajan (2005), hubungan agensi ada ketika pihak principal menyewa agen untuk melaksanakan suatu jasa dengan pemberian wewenang oleh principal untuk membuat suatu keputusan.

Dalam suatu organisasi perusahaan, principal tidak selalu mengetahui aktivitas agen dan kondisi di unit tanggungjawab agen tersebut. Karena principal tidak memiliki informasi yang mencukupi mengenai kinerja agen maka principal tidak pernah bisa mengetahui secara pasti bagaimana usaha agen memberikan kontribusinya pada perusahaan. Kondisi ini disebut sebagai asimetri informasi.

Perbedaan tujuan antara principal dan agen serta adanya kondisi asimetri informasi dapat menyebabkan agen salah menyajikan informasi kepada principal. Hal ini berlaku dalam proses penyusunan anggaran partisipatif. Jika agen yang berpartisipasi dalam penyusunan anggaran mempunyai informasi yang tidak dimiliki principal maka 
akan memungkinkan agen tersebut melakukan senjangan anggaran agar anggaran yang ditetapkan tersebut mudah untuk dicapai sehingga agen terlihat memiliki kinerja yang baik di mata principal.

\section{Anggaran}

\section{a. Pengertian Anggaran}

Anggaran adalah suatu rencana yang disusun secara sistematis yang meliputi seluruh kegiatan perusahaan yang dinyatakan dalam unit moneter dan berlaku untuk jangka waktu tertentu di masa mendatang (Munandar, 1985). Menurut Agus (2008), anggaran merupakan perencanaan secara formal yang mencakup seluruh kegiatan perusahaan untuk jangka waktu tertentu dan dinyatakan dalam unit kuantitatif (moneter). Disebut formal karena dalam penyusunan anggaran harus dilakukan pertemuan-pertemuan resmi di perusahaan tersebut, lalu anggaran yang telah ditetapkan dinyatakan secara tertulis. Anggaran menurut Nafarin (2007) adalah rencana tertulis mengenai kegiatan suatu organisasi yang dinyatakan secara kuantitatif yang dinyatakan dalam satuan moneter dan berlaku untuk jangka waktu tertentu.

Dari pengertian-pengertian anggaran di atas dapat disimpulkan bahwa anggaran meliputi:

a) Perencanaan

Anggaran merupakan suatu rencana yang akan dilakukan mengenai kegiatan perusahaan di masa yang akan datang. Rencana yang dibuat 
harus sistematis dan tertulis. Perencanaan dilakukan secara formal, yaitu melalui pertemuan-pertemuan resmi.

b) Mencakup seluruh kegiatan

Suatu perusahaan terdiri dari berbagai unit tanggungjawab, oleh karena itu dalam menyusun anggaran harus mencakup seluruh unit tanggungjawab tersebut. Anggaran yang tidak mencakup seluruh kegiatan akan membuat anggaran tersebut tidak lengkap dan akan mempengaruhi kegiatan di unit tanggungjawab lainnya.

c) Dinyatakan dalam satuan moneter

Dalam menyusun anggaran diperlukan satuan unit yang sama untuk beraneka macam kegiatan perusahaan agar dapat dilakukan perbandingan untuk dapat ditindaklanjuti. Satuan unit tersebut biasanya dinyatakan dalam unit moneter.

d) Berjangka waktu tertentu

Anggaran yang dibuat berlaku dalam jangka waktu tertentu agar dapat mempermudah penilaian pencapaian target anggaran sesuai dengan jangka waktu yang telah ditetapkan.

Menurut Abdullah (2012) anggaran merupakan alat untuk mengalokasikan sumber-sumber daya yang dimiliki perusahaan, menetapkan target anggaran, dan sebagai alat untuk mengevaluasi kinerja manajer bawah. Sumber-sumber daya terbatas yang dimiliki perusahaan harus dialokasikan dengan tepat dengan memperhatikan efisiensi dan efektivitas. Dalam anggaran terdapat target yang harus 
dicapai manajer untuk mencapai tujuan perusahaan. Selain itu, anggaran adalah alat untuk mengevaluasi kinerja manajer melalui perbandingan realisasi anggaran dengan anggaran.

\section{b. Karakteristik Anggaran}

Menurut Anthony \& Govindarajan (2005), anggaran memiliki karakterikstik-karakteristik sebagai berikut:

1) Anggaran mengestimasi potensi laba dari suatu unit bisnis/divisi.

2) Dinyatakan dalam istilah moneter dengan didukung oleh istilah nonmoneter.

3) Biasanya dibuat untuk jangka waktu satu tahun, kecuali untuk bisnis musiman yang membuat anggaran per musim.

4) Merupakan komitmen manajemen untuk bertanggungjawab untuk mencapai target dalam anggaran.

5) Usulan anggaran ditinjau dan disetujui oleh pejabat yang lebih tinggi wewenangnya dari pembuat anggaran.

6) Anggaran yang disetujui hanya bisa diubah dalam kondisi-kondisi tertentu.

7) Secara berkala, anggaran akan dibandingkan dengan kinerja keuangan aktual dan dianalisis variansnya. 


\section{c. Keefektifan Anggaran}

Menurut Siegel \& Shim (2001), agar suatu anggaran efektif diperlukan antara lain:

1) Kemampuan prediksi

Manajer harus memiliki kemampuan untuk memprediksi dengan baik karena kemampuan tersebut berpengaruh pada anggaran yang ditetapkan untuk mencapai tujuan perusahaan. Kegagalan manajer dalam memprediksi dapat merugikan perusahaan karena membuat manajer bawah mengambil keputusan yang tidak tepat.

2) Saluran komunikasi, wewenang, dan tanggung jawab yang jelas

Dalam menyusun anggaran, komunikasi harus terjalin antara manajer atas dan manajer bawah sebagai media pertukaran informasi yang diperlukan untuk menyusun anggaran. Selain itu, wewenang dan tanggungjawab juga harus jelas agar koordinasi antar unit tanggungjawab dapat terlaksana.

3) Informasi yang akurat dan tepat waktu

Dalam menyusun anggaran diperlukan informasi yang akurat dan tepat waktu karena tanpanya manajer bawah dapat membuat keputusan yang tidak tepat dan tidak bisa digunakan sebagai pedoman kerja karena sudah tidak bisa digunakan. 
4) Bersifat menyeluruh, dan kejelasan informasi

Anggaran yang dibuat harus mencakup semua unit fungsional di perusahaan dan juga harus berisi informasi yang jelas mengingat anggaran digunakan sebagai pedoman kerja.

5) Dukungan dalam organisasi dari semua pihak yang terlibat

Dalam menyusun anggaran, dukungan dari semua pihak dari dalam organisasi sangat diperlukan karena anggaran bersifat menyeluruh yang mencakup semua unit fungsional. Anggaran yang tidak didukung oleh semua pihak akan menimbulkan ketidaklengkapan dan akan berdampak pada anggaran secara keseluruhan mengingat dalam anggaran setiap unti fungsional terkait satu sama lain.

\section{d. Fungsi Anggaran}

Menurut Didit (2011), ada empat fungsi anggaran, yaitu:

1) Fungsi Perencanaan

Dalam menyusun anggaran, manajer bawah akan merencanakan kegiatan-kegiatan apa yang akan dilakukan di masa datang, bagaimana cara untuk melaksanakan kegiatan-kegiatan tersebut, serta bagaimana hasil yang akan dicapai dari kegiatan-kegiatan tersebut. Dengan adanya perencanaan tersebut, kegiatan-kegiatan yang akan dilaksanakan di masa depan diharapkan dapat terlaksana dengan baik dengan hasil yang sesuai harapan. 
2) Fungsi Koordinasi

Anggaran berfungsi sebagai alat mengkoordinasikan rencana dan tindakan berbagai divisi/departemen/bagian yang ada dalam organisasi agar dapat bekerja secara selaras kearah pencapaian tujuan.

3) Fungsi Pengawasan

Pengawasan berarti mengevaluasi perealisasian anggaran. Pengevaluasian tersebut dilakukan dengan cara:

a) Membandingkan realisasi dengan rencana anggaran.

b) Melakukan tindakan perbaikan bila dipandang perlu

4) Anggaran sebagai Pedoman Kerja

Anggaran merupakan suatu rencana kerja yang disusun secara sistematis dan dinyatakan dalam unit moneter. Dengan anggaran, manajer dapat mengetahui tindakan-tindakan apa saja yang akan dilakukannya.

Menurut Nafarin (2007), fungsi anggaran ada tiga, yaitu:

1) Fungsi Perencanaan

Anggaran sebagai alat perencanaan yang mencakup seluruh kegiatan perusahaan di masa datang.

2) Fungsi Pelaksanaan

Anggaran yang ditetapkan sebagai pedoman pelaksanaan kegiatan perusahaan yang akan dilaksanakan dan juga digunakan untuk menyelaraskan kegiatan di setiap unit fungsional untuk mencapai tujuan anggaran. 


\section{3) Fungsi Pengawasan}

Anggaran sebagai alat pengawasan atau pengendalian kegiatan yang dilaksanakan manajer bawah dengan mengevaluasi kegiatan tersebut dengan cara membandingkan realisasi dengan anggaran dan melakukan tindak lanjut jika terdapat penyimpangan yang merugikan.

Dari beberapa pendapat mengenai fungsi anggaran, dapat disimpulkan bahwa fungsi anggaran meliputi fungsi perencanaan, dimana anggaran sebagai alat perencanaan kegiatan perusahaan di masa datang; fungsi pelaksanaan, dimana anggaran sebagai pedoman kerja bagi manajer bawah dan sebagai alat koordinasi pada unit fungsional; serta fungsi pengawasan atau pengendalian, dimana anggaran digunakan untuk mengevaluasi pelaksanaan kegiatan perusahaan.

\section{e. Manfaat Anggaran}

Menurut Anthony \& Govindarajan (2005) anggaran memiliki manfaat, antara lain:

1) Menyelaraskan rencana strategis

Anggaran digunakan untuk menyelaraskan rencana strategis karena anggaran dibuat berdasarkan rencana strategis tersebut. Jika realisasi anggaran pada tahun sebelumnya kurang memuaskan maka manajer akan melakukan perbaikan yang dapat meningkatkan kinerja sehingga akan sesuai dengan rencana strategis perusahaan. 


\section{2) Koordinasi}

Anggaran mencakup semua unit tanggungjawab yang ada di perusahaan. Oleh karena itu, dibutuhkan koordinasi antar manajer dalam menyusun anggaran agar selaras dengan tujuan perusahaan.

3) Penugasan tanggungjawab Anggaran yang telah disetujui memperjelas tanggungjawab setiap manajer di tiap-tiap unit fungsional. Setiap manajer bertanggungjawab untuk mencapai target anggaran yang telah ditetapkan. Anggaran juga memberikan wewenang kepada manajer untuk melakukan kegiatan yang sudah direncanakan dalam anggaran.

4) Alat evaluasi kinerja

Anggaran digunakan untuk mengevaluasi kinerja manajer dengan membandingkan realisasi anggaran dengan anggaran. Jika terdapat penyimpangan yang merugikan perusahaan maka akan dicari tahu penyebabnya dan dilakukan perbaikan.

Menurut Hansen \& Mowen (2006), manfaat anggaran sebagai berikut:

1) Memaksa manajer melakukan perencanaan

Untuk membuat anggaran maka manajer bawah harus melakukan perencanaan mengenai kegiatan apa saja yang akan dilakukan perusahaan di masa depan.

2) Menyediakan informasi yang dapat digunakan untuk memperbaiki pembuatan keputusan 
Anggaran digunakan untuk memperbaiki pembuatan keputusan berdasarkan hasil realisasi anggaran. Jika realisasi anggaran kurang memuaskan maka akan dilakukan perbaikan mengenai keputusan yang akan diambil selanjutnya.

3) Mengevaluasi kinerja

Anggaran digunakan untuk mengevaluasi kinerja dengan membandingkan realisasi anggaran dengan anggaran. Jika terdapat perbedaan yang menyimpang maka akan ditindak lanjuti.

4) Memperbaiki komunikasi dan koordinasi

Anggaran mencakup semua unit fungsional di perusahaan sehingga dibutuhkan komunikasi dan koordinasi dalam menyusun anggaran sehingga selaras dengan tujuan perusahaan.

Dari beberapa pendapat mengenai manfaat anggaran maka dapat ditarik kesimpulan bahwa manfaat anggaran, yaitu: 1) dapat memaksa manajer bawah untuk melakukan perencanaan mengenai aktivitas apa yang akan dilakukan perusahaan di masa depan dan 2) digunakan untuk menyelaraskan perencanaan strategis yang telah dibuat sebelumnya sehingga sesuai dengan tujuan yang ingin dicapai perusahaan; 3) memperbaiki komunikasi dan koordinasi antar unit fungsional mengingat dalam penyusunan anggaran melibatkan seluruh unit fungsional yang ada di perusahaan; 4) anggaran memperjelas tanggungjawab manajer di tiaptiap unit tanggungjawab untuk dapat mencapai target anggaran; dan 5) anggaran digunakan untuk mengevaluasi kinerja manajer bawah dengan 
membandingkan realisasi anggaran dengan target anggaran dan menindaklanjuti jika ada perbedaan.

\section{f. Penyusunan Anggaran}

Menurut Welsch, Hilton \& Gordon (2000:42), ada empat tahapan dalam penyusunan anggaran, yaitu:

1) Manajemen atas menentukan tujuan perusahaan, sasaran, strategi, asumsi perencanaan, dan pedoman yang disampaikan kepada para manajer subunit.

2) Manajer subunit membuat anggaran berdasarkan pedoman.

3) Manajer dari setiap subunit mengajukan anggaran yang telah dibuatnya kepada manajemen atas untuk dievaluasi dan untuk mengetahui apakah anggaran yang diajukan tersebut perlu diperbaiki atau tidak.

4) Anggaran dari setiap subunit, setelah disetujui oleh manajemen atas kemudian dikonsolidasikan menjadi anggaran secara menyeluruh untuk perusahaan.

Menurut Anthony \& Govindarajan (2005), ada beberapa tahapan dalam proses penyusunan anggaran, yaitu:

1) Penerbitan pedoman

Pedoman anggaran dibuat berdasarkan perencanaan strategis yang telah dibuat dan dimodifikasi sesuai dengan perkembangan perusahaan. Pedoman berisi asumsi-asumsi dan kebijakan yang digunakan untuk membuat anggaran. Pedoman tersebut dibuat oleh departemen anggaran yang disetujui oleh komite anggaran. Pedoman anggaran tersebut 
kemudian disebarkan kepada semua manajer yang akan digunakan untuk mengusulkan anggaran.

2) Usulan awal anggaran

Dengan menggunakan pedoman yang diterbitkan oleh departemen anggaran, manajer unit tanggungjawab dibantu dengan stafnya membuat usulan awal anggaran. Pembuatan usulan awal anggaran berdasarkan pertimbangan mengenai sumber-sumber daya yang ada di unit tanggungjawabnya.

3) Negosiasi

Negosiasi berupa pendiskusian usulan anggaran antara manajer unit tanggungjawab dengan departemen anggaran. Departemen anggaran akan mengevaluasi anggaran yang dibuat manajer unit tanggungjawab. Setelah dievaluasi, departemen anggaran akan menggabungkan anggaran yang dibuat masing-masing unit tanggungjawab.

4) Tinjauan dan persetujuan

Setelah usulan anggaran dinegosiasikan dan digabungkan, usulan anggaran tersebut akan diserahkan kepada komite anggaran. Komite anggaranakan meninjau usulan anggaran tersebut. Manajemen puncak akan menganalisis tiap-tiap komponen anggaran yang diusulkan. Jika anggaran diterima dan disetujui, selanjutnya akan direkomendasikan oleh komite anggaran kepada CEO. CEO akan menyerahkan anggaran yang telah disetujui kepada dewan direksi untuk disahkan. 


\section{5) Revisi Anggaran}

Jika asumsi-asumsi yang digunakan dalam menyusun anggaran sudah tidak relevan lagi maka revisi anggaran perlu dilakukan untuk menyesuaikan dengan keadaan.

Menurut Shim \& Siegel (2001), ada enam tahap dalam menyusun anggaran, yaitu:

1) Penetapan tujuan

2) Pengevaluasian sumber-sumber daya yang tersedia

3) Negosiasi antara pihak-pihak yang terlibat mengenai angka-angka anggaran

4) Pengkoordinasian dan peninjauan komponen

5) Persetujuan akhir

6) Pendistribusian anggaran yang disetujui

Dari beberapa pendapat mengenai tahap penyusunan anggaran. maka dapat ditarik kesimpulan bahwa langkah-langkah dalam menyusun anggaran meliputi: 1) menetapkan tujuan yang berkaitan dengan apa yang ingin dicapai perusahaan di masa depan dimana tujuan tersebut dijadikan dasar untuk membuat perencanaan strategis; 2) menetapkan pedoman yang berisi asumsi dan kebijakan yang digunakan untuk menyusun anggaran; 3) manajer bawah mengusulkan anggaran kepada atasannya; 4) manajer bawah melakukan negosiasi kepada departemen anggaran mengenai anggaran yang diusulkan; 5) setelah anggaran dinegosiasikan, selanjutnya akan diserahkan kepada komite anggaran untuk ditinjau konsistensi 
perhitungan dan keterpaduan antara tujuan perusahaan dengan target anggaran; 6) jika komite anggaran menyetujui anggaran yang diusulkan maka komite anggaran akan merekomendasikan anggaran tersebut kepada CEO dan CEO akan menyerahkan anggaran kepada dewaan direksi untuk disahkan; 7) anggaran yang sudah disahkan kemudian didistribusikan kepada manajer bawah untuk dilaksanakan.

\section{Partisipasi Anggaran}

\section{a. Pengertian Partisipasi Anggaran}

Anthony \& Govindarajan (2005) menyatakan bahwa partisipasi anggaran adalah proses dimana pembuat anggaran terlibat dan mempunyai pengaruh dalam menentukan anggaran. Menurut Brownell (1982), partisipasi anggaran diartikan sebagai keterlibatan dan pengaruh manajer bawah dalam penyusunan anggaran di mana manajer bawah dan manajer atas bersama-sama mengambil keputusan dalam menetapkan anggaran final yang dapat mempengaruhi unit tanggungjawab manajer bawah.

Dari definisi-definisi di atas dapat ditarik kesimpulan bahwa partisipasi anggaran meliputi:

1) Keterlibatan manajer bawah dalam menyusun anggaran

Keterlibatan manajer bawah ditandai dengan manajer bawah mengusulkan anggaran kepada manajer atas. 
2) Manajer bawah memiliki pengaruh dalam menetapkan anggaran final Manajer bawah tidak hanya terlibat dalam menyusun anggaran, tetapi juga memiliki pengaruh dalam menetapkan anggaran final. Pengaruh tersebut ditandai dengan manajer bawah dan manajer atas bersamasama mengambil keputusan mengenai penetapan anggaran final.

\section{b. Alasan Pelaksanaan Partisipasi Anggaran}

Menurut Kyj \& Parker (2008), alasan manajer atas melakukan kebijakan partisipasi anggaran adalah:

1) Untuk menciptakan hubungan komunikatif antara manajer atas dengan manajer bawah.

Dengan partisipasi anggaran maka manajer atas dan manajer bawah dapat saling berkomunikasi untuk memunculkan rasa percaya dan dukungan dari manajer bawah.

2) Untuk mengakses informasi privat yang dimiliki manajer bawah.

Dengan adanya komunikasi antara manajer atas dan manajer bawah maka diharapkan manajer bawah mau memberikan informasi privatnya kepada manajer atas untuk digunakan dalam penyusunan anggaran.

3) Untuk menciptakan keadilan bagi manajer bawah jika anggaran digunakan untuk mengevaluasi kinerja manajer bawah.

Dengan partisipasi anggaran maka manajer bawah ikut berpartisipasi dalam menyusun anggaran sehingga akan adil bagi manajer bawah 
bila manajer atas menggunakan anggaran tersebut sebagai alat untuk mengevaluasi kinerja manajer bawah.

\section{c. Manfaat Partisipasi Anggaran}

Menurut Welsch, Hilton, \& Gordon (2000), partisipasi memberikan manfaat, yaitu:

1) Partisipasi anggaran mengurangi asimetri informasi antara manajer atas dengan manajer bawah

Dengan adanya partisipasi anggaran, diharapkan manajer bawah dapat memberikan informasi yang dimilikinya kepada manajer atas sehingga dapat mengurangi asimetri informasi. Dengan begitu, anggaran yang ditetapkan dapat sesuai dengan kemampuan terbaik manajer bawah. Dengan pengumpulan informasi dari semua manajer bawah yang berpartisipasi dalam penyusunan anggaran dimana mereka lebih paham akan kondisi unit tanggungjawabnya maka perusahaan akan dapat menetapkan sasaran anggaran yang sesuai dan dapat dicapai daripada sasaran anggaran yang ditetapkan oleh manajer atas. Dengan begitu, strategi yang dilaksanakan juga akan lebih baik untuk mencapai sasaran anggaran.

2) Partisipasi anggaran dapat menghasilkan komitmen yang lebih besar dari manajer bawah untuk melaksanakan anggaran Manajer bawah ikut terlibat dan memiliki pengaruh dalam menetapkan anggaran final sehingga anggaran yang ditetapkan sesuai dengan keinginannya. Mengingat anggaran yang ditetapkan 
berdasarkan pada usulan dari manajer bawah maka akan memunculkan komitmen pada diri manajer bawah untuk dapat melaksanakan anggaran dan dapat mencapai target anggaran.

Menurut Arfan (2011), manfaat partisipasi anggaran adalah sebagai berikut:

1) Partisipasi anggaran membuat manajer bawah merasa dihargai oleh perusahaan karena manajer bawah dapat terlibat dan memberikan pengaruh pada penetapan anggaran final.

2) Partisipasi anggaran mendorong inisiatif yang lebih besar karena manajer bawah ikut berpikir dan memberikan ide-ide dan pendapatnya kepada manajer atas.

3) Partisipasi anggaran dapat meningkatkan rasa kesatuan kelompok sehingga kerjasama antar kelompok dalam penetapan tujuan organisasi cenderung meningkat. Hal ini karena manajer bawah dan manajer puncak bersama-sama berpikir dan saling bertukar pikiran dalam menentukan anggaran sehingga anggaran yang ditetapkan dapat diterima oleh manajer bawah danmanajer atas. Tujuan perusahaan yang dibantu penetapannya oleh manajer bawah dipandang sebagai tujuan yang selaras dengan tujuan pribadi manajer bawah yang disebut sebagai internalisasi tujuan.

4) Partisipasi anggaran dapat menurunkan tekanan dan kegelisahan terkait target anggaran yang harus dicapai manajer bawah. Dengan adanya partisipasi anggaran, manajer bawah ikut menentukan 
anggaran dengan mengajukan usulan anggaran kepada manajer atas sehingga target anggaran tersebut sesuai dengan kemampuan manajer bawah yang sebenarnya.

5) Partisipasi anggaran dapat menurunkan ketidakadilan serta reaksi negatif atas persepsi ketidakadilan tersebut.

Dari beberapa pendapat mengenai manfaat partisipasi anggaran maka dapat dirangkum bahwa manajer bawah ikut berpartisipasi dalam menyusun anggaran, hal ini akan memunculkan komunikasi positif antara manajer atas dan manajer bawah di mana manajer bawah mau memberikan informasi yang dimilikinya untuk digunakan dalam penyusunan anggaran.

Adanya partisipasi anggaran akan memunculkan inisiatif ide-ide atau pendapat dari manajer bawah terkait dengan rencana kegiatan yang akan dinyatakan dalam anggaran. Karena dapat memberikan pendapatnya kepada manajer atas akan membuat manajer bawah merasa dihargai dan memunculkan rasa keadilan bagi manajer bawah karena anggaran yang ditetapkan sesuai dengan kemampuannya, juga dapat menghilangkan tekanan dan kegelisahan akibat tekanan untuk dapat mencapai target anggaran. Dengan begitu, akan tercipta rasa kesatuan antara manajer atas dan manajer bawah karena adanya kerjasama untuk mencapai tujuan perusahaan. Karena manajer bawah ikut dalam menetapkan anggaran final maka akan memunculkan komitmen pada 
diri manajer bawah untuk dapat mencapai target anggaran. Hal tersebut akan berdampak pada peningkatan kinerja manajer bawah.

\section{d. Permasalahan Partisipasi Anggaran}

Menurut Hansen \& Mowen (2006), anggaran partisipatif memiliki tiga potensi masalah, antara lain:

1) Menetapkan standar yang terlalu tinggi atau terlalu rendah Beberapa manajer bawah mungkin cenderung membuat anggaran yang terlalu tinggi atau terlalu rendah. Jika anggaran terlalu tinggi maka akan membuat manajer bawah kesulitan untuk mencapai target anggaran sehingga akan menimbulkan rasa frustasi pada manajer bawah yang mengakibatkan penurunan kinerja manajer bawah. Jika anggaran terlalu rendah atau mudah akan membuat manajer bawah kehilangan minat untuk melaksanakan anggaran yang mengakibatkan penurunan kinerja.

2) Senjangan anggaran

Partisipasi anggaran membuat manajer bawah memiliki kesempatan untuk melakukan senjangan anggaran. Manajer bawah melakukan senjangan anggaran dengan meninggikan biaya atau merendahkan pendapatan sehingga manajer bawah dapat lebih mudah dalam mencapai target anggaran dan juga untuk memperkecil risiko yang akan dihadapi manajer bawah. 
3) Partisipasi semu

Partisipasi semu muncul ketika manajer bawah tidak benar-benar berpartisipasi dalam anggaran. Manajer atas hanya mendapatkan persetujuan formal anggaran dari manajer bawah bukan pendapat dan informasi dari manajer bawah.

\section{Senjangan Anggaran}

\section{a. Pengertian Senjangan Anggaran}

Schiff \& Lewin (1970) menyatakan bahwa senjangan anggaran merupakan tindakan dimana manajer bawah meninggikan kebutuhan akan sumber-sumber daya yang dimiliki perusahaan yang dialokasikan untuk melaksanakan kegiatan perusahaan atau manajer bawah merendahkan kemampuan kinerjanya ketika diberi kesempatan untuk mempengaruhi penetapan anggaran dimana anggaran yang ditetapkan tersebut akan digunakan untuk mengevaluasi kinerja manajer bawah.

Menurut Lukka (1988), manajer bawah membuat senjangan anggaran dengan merendahkan target anggaran dari estimasi terbaiknya sehingga target anggaran dapat lebih mudah untuk dicapai, sedangkan senjangan anggaran menurut Kren (2003) ditunjukkan dengan menyajikan biaya lebih besar dari yang seharusnya dibutuhkan atau menyajikan pendapatan lebih rendah dari yang seharusnya bisa diperoleh sehingga dapat dikatakan manajer bawah menurunkan kapabilitas/kemampuan kinerja dari kemampuan yang sebenarnya. 
Senjangan anggaran menurut Anthony \& Govindarajan (2005) adalah perbedaan antara jumlah anggaran yang diajukan dengan estimasi terbaik, sedangkan Faria \& Silva (2013) menyatakan bahwa senjangan anggaran muncul ketika manajer bawah meninggikan pengeluaran, merendahkan pendapatan, dan meninggikan kebutuhan sumber-sumber daya untuk dialokasikan dalam anggaran dengan tujuan untuk memperoleh kepuasan pribadi dengan mendapatkan insentif dari tercapainya target anggaran.

Dari beberapa pendapat di atas dapat disimpulkan bahwa senjangan anggaran merupakan tindakan manajer bawah yang merendahkan kemampuan kinerjanya dengan mengusulkan anggaran yang lebih rendah dari estimasi terbaiknya yang ditandai dengan meninggikan kebutuhan akan sumber-sumber daya yang dimiliki yang dialokasikan melalui anggaran atau dengan kata lain meninggikan pengeluaran dari biaya yang sebenarnya dibutuhkan atau merendahkan pendapatan dari pendapatan yang seharusnya bisa diperoleh sehingga target anggaran dapat lebih mudah dicapai.

\section{b. Penyebab Senjangan Anggaran}

Manajer bawah dapat melakukan senjangan anggaran karena perusahaan menerapkan penganggaran partisipatif sehingga hal tersebut memunculkan kesempatan bagi manajer bawah untuk melakukan senjangan anggaran.Tanpa adanya partisipasi anggaran maka manajer bawah tidak bisa melakukan senjangan anggaran karena anggaran 
ditetapkan oleh manajer atassehingga tidak ada kesempatan untuk melakukannya (Douglas \& Wier, 2000).

Menurut Welsch, Hilton \& Gordon (2000), partisipasi dalam membuat anggaran dapat memunculkan adanya keinginan untuk menciptakan senjangan anggaran. Pendapat umum yang dikemukakan, menjelaskan mengenai penyebab timbulnya keinginan tersebut, antara lain:

1) Untuk melindungi diri sehingga kinerja manajer tidak akan dikritik dengan cara manajer bawah menetapkan anggaran penjualan lebih rendah dari estimasi terbaik.

2) Agar kinerja manajer bawah terlihat baik oleh manajemen atas dengan cara manajer bawah menetapkan perkiraan pengeluaran lebih tinggi dari estimasi terbaik.

3) Agar manajer bawah tidak perlu meminta pengeluaran kas lagi dengan caramanajer bawah meminta pengeluaran kas yang melebihi kebutuhan sebenarnya. Ketika kas tersisa dan dikembalikan maka akan terlihat baik oleh atasan.

Manajemen bawah membuat senjangan anggaran pada anggaran yang diusulkan ke manajer atas. Saat manajer atas meninjau dan mengevaluasi anggaran tersebut, mereka akan menilai apakah anggaran yang ditetapkan tadi mengeluarkan biaya yang terlalu banyak atau tidak dan apakah dengan pengeluaran biaya tersebut menghasilkan pendapatan yang optimal atau tidak. Jika pengeluaran biaya yang ditetapkan terlalu 
besar maka manajer atasakan memotong anggaran tersebut. Karena pemotongan anggaran tersebut, manajer bawah akan membuat senjangan anggaran yang lebih besar untuk terhindar dari anggaran yang terlalu ketat sehingga walaupun anggaran yang diusulkan dipotong oleh manajer atas, sebenarnya masih terdapat senjangan anggaran pada usulan anggaran tersebut Welsch, Hilton \& Gordon (2000).

Beberapa peneliti menyatakan bahwa senjangan anggaran dapat muncul karena kondisi seperti di bawah ini:

1) Adanya asimetri informasi antara manajer atas dengan manajer bawah

Manajer bawah melakukan senjangan anggaran dengan memanfaatkan adanya asimetri informasi dimana manajer atas tidak mengetahui informasi di unit tanggungjawab manajer bawah sehingga manajer bawah memiliki kesempatan untuk memberikan informasi yang tidak benar terkait penyusunan anggaran (Stevens, 2002; Faria \& Silva, 2013).

2) Adanya ketidakpastian antara usaha yang dikeluarkan dengan output yang akan diperoleh

Manajer bawah melakukan senjangan anggaran untuk melindungi mereka dari ketidakpastian lingkungan sehingga terdapat ketidakpastian antara usaha yang dikeluarkan dengan output yang akan diperoleh yang dapat berdampak pada pencapaian target anggaran (Schiff \& Lewin, 1970; Onsi, 1973). Pencapaian target 
anggaran digunakan manajer atas untuk menilai kinerja manajer bawah, jika manajer bawah gagal memenuhi target karena adanya kejadian yang tidak diduga maka kinerja manajer bawah akan terlihat buruk. Hal ini tentu tidak diinginkan oleh manajer bawah.

3) Adanya perbedaan kepentingan antara manajer atas dan manajer bawah

Manajer bawah memanfaatkan asimetri informasi untuk membuat senjangan anggaran karena dipicu oleh adanya insentif yang diberikan atas keberhasilan mencapai target anggaran (Douglas \& Wier, 2000). Luthans (1998) menyatakan senjangan anggaran timbul karena keinginan dari manajer bawah dan manajer atas yang tidak sama terutama jika kinerja manajer bawah dinilai berdasarkan pencapaian anggaran. Apabila manajer bawah merasa insentifnya tergantung pada pencapaian sasaran anggaran, maka manajer bawahakan membuat senjangan anggaran (Schiff dan Lewin, 1970; Chow et al., 1988).

\section{c. Dampak Senjangan Anggaran}

Senjangan anggaran dapat mengakibatkan pengalokasian sumber-sumber daya yang tidak efisien, anggaran yang ditetapkan menjadi tidak efektif, dan fungsi anggaran sebagai alat menilai kinerja manajer bawah menjadi tidak berfungsi dengan baik karena anggaran yang ditetapkan tidak mencerminkan kemampuan sebenarnya dari manajer bawah (Abdullah, 2012). Menurut Onsi (1973), senjangan 
anggaran dipandang sebagai perilaku disfungsional oleh perusahaan karena dapat menyebabkan perusahaan kehilangan kesempatan untuk memperoleh laba optimal serta tidak mengarah pada penghematan pengeluaran biaya.

Selain itu, jika suatu anggaran yang ditetapkan terdapat senjangan anggaran, maka akan mempengaruhi anggaran untuk tahun berikutnya. Biasanya, anggaran yang sedari awal sudah terdapat senjangan anggaran maka untuk anggaran tahun berikutnya akan terdapat senjangan anggaran yang semakin besar. Hal tersebut didukung oleh penelitian yang dilakukan oleh Stevens (2002) yang meneliti mengenai peningkatan senjangan anggaran seiring dengan tahun periode anggaran. Hal tersebut karena manajer bawah akan menetapkan anggaran tahun berikutnya berdasarkan anggaran yang sudah terdapat senjangan anggaran di mana kinerja anggaran tersebut di bawah kemampuan kinerja manajer bawah.

Anggaran yang terdapat senjangan anggaran mencerminkan kinerja anggaran di bawah kemampuan kinerja manajer bawah, jika anggaran tersebut digunakan untuk menyusun anggaran selanjutnya maka anggaran periode selanjutnya juga akan berada di bawah kemampuan kinerja manajer bawah, sedangkan kemampuan kinerja manajer bawah semakin meningkat seiring dengan pengalaman kinerjanya. 
Jika senjangan anggaran terus terjadi maka akan membuat perusahaan memiliki kinerja yang tidak optimal. Hal tersebut akan membuat perusahaan kurang bisa bersaing dengan perusahaan kompetitor. Jika hal tersebut terjadi bukan tidak mungkin perusahaan akan mengalami kerugian karena kehilangan pelanggan. Perusahaan yang mengalami kerugian tentu tidak akan dilirik oleh investor. Jika demikian, perusahaan akan kehilangan modal untuk mengembangkan perusahaan.

\section{d. Mencegah Senjangan Anggaran}

Anggaran yang telah disusun secara partisipatif perlu dievaluasioleh departemen anggaran, hal ini untuk menghindari terjadinya estimasi anggaran yang mengandung senjangan anggaran oleh manajer bawah.

Senjangan anggaran dapat ditekan dengan tugas departemen anggaran dalam menganalisis usulan anggaran dari manajer bawah dan memastikan apakah informasi yang diberikan manajer bawah akurat atau tidak (Anthony \& Govindarajan, 2005). Manajer atas harus menguji dasar pembuatan anggaran yang dilakukan manajer bawah dan juga melihat buktinya (Welcsh, Hilton, \& Gordon, 2000).

Saat departemen anggaran mengevaluasi anggaran tersebut, mereka akan menilai apakah anggaran yang ditetapkan mengeluarkan biaya yang terlalu banyak atau tidak dan apakah dengan pengeluaran biaya tersebut menghasilkan pendapatan yang optimal atau tidak. Jika 
pengeluaran biaya yang ditetapkan terlalu besar maka departemen anggaran akan memotong anggaran tersebut.

Untuk mengurangi senjangan anggaran maka manajer puncak harus meyakinkan manajer bawah bahwa perubahan anggaran dapat disetujui setiap saat dengan mempertimbangkan alasan-alasan yang dapat diterima sebagai bukti. Jika anggaran yang telah disusun dianggap memerlukan perubahan, maka perubahan tersebut harus didiskusikan dan dimodifikasi berdasarkan kesepakatan bersama. Hal tersebut dilakukan untuk mengurangi senjangan anggaran yang dilakukan dengan maksud untuk melindungi diri dari ketidakpastian lingkungan.

\section{Intensif}

\section{a. Pengertian Kompensasi}

Kompensasi adalah semua bentuk return baik finansial maupun nonfinansial yang diterima bawahan karena jasa yang telah disumbangkannya kepada perusahaan. Kompensasi merupakan salah satu strategi manajemen sumber daya manusia untuk menciptakan keselarasan kerja antara bawahan dengan atasan dalam mencapai tujuan dan sasaran yang sudah ditetapkan (Simamora, 1995). Kompensasi finansial adalah berbentuk gaji, upah, bonus, komisi, tunjangan, dan sebagainya. Kompensasi nonfinansial adalah berupa tugas-tugas yang menarik, tugas yang memiliki tantangan, tanggungjawab, pengakuan.

Menurut Anthony \& Govindarajan (2005), kompensasi total dari seorang manajer terdiri dari gaji, tunjangan, dan insentif. Ketiga 
komponen tersebut saling bergantung, namun komponen insentif berkaitan dengan pengendalian manajemen.

\section{b. Pengertian Insentif}

Menurut Simamaora (1995), insentif diartikan sebagai bentuk pembayaran langsung yang didasarkan pada hasil kinerja. Sistem ini merupakan bentuk lain dari upah langsung di luar gaji dan upah yang merupakan kompensasi tetap, yang disebut kompensasi berdasarkan kinerja (pay for performance plan). Insentif menurut Hani (2000) merupakan sistem pemberian balas jasa yang berdasarkan pada kinerja manajer yang berbentuk materiil atau nonmaterial yang dapat memotivasi manajer agar meningkatkan kinerjanya untuk mencapai tujuan perusahaan.

Berdasarkan kedua pengertian tersebut maka insentif merupakan sistem pembalasan balas jasa yang berdasarkan pada kinerja manajer yang bertujuan untuk memotivasi manajer agar dapat meningkatkan kinerjanya. Insentif yang diberikan dapat berupa materiil atau nonmaterial, di luar gaji dan upah.

\section{c. Tujuan Insentif}

Menurut Hadari (2001), insentif bertujuan untuk:

1) Memberikan motivasi kepada manajer agar manajer dapat meningkatkan kinerjanya sehingga pada nantinya tujuan perusahaan akan tercapai. 
2) Membedakan antara manajer yang berprestasi dengan manajer yang kurang berprestasi karena manajer yang berprestasi akan mendapatkan insentif yang besar.

Menurut Hani (2000), tujuan insentif adalah:

1) Memotivasi manajer agar mau mendayagunakan kemampuannya untuk mencapai tujuan perusahaan.

2) Memelihara serta mempertahankan manajer yang berkompetensi agar tetap berada di perusahaan.

3) Menjamin keadilan di mana manajer sudah memberikan kemampuannya untuk kepentingan perusahaan sehingga perlu untuk diberi balas jasa.

4) Memunculkan kepuasan kerja karena dapat memenuhi kebutuhankebutuhan fisik, status, dan sosial.

Berdasarkan pendapat mengenai tujuan insentif dapat ditarik kesimpulan bahwa tujuan insentif adalah 1) memotivasi manajer agar dapat meningkatkan kinerjanya; 2) mempertahankan manajer yang kompeten; 3) memberikan keadilan bagi manajer karena sudah memberikan kemampuannya; 4) kepuasan kinerja bagi manajer karena memenuhi kepentingannya. 


\section{d. Jenis Insentif}

Menurut Anthony \& Govindarajan (2005), insentif dibagi menjadi dua jenis, yaitu:

1) Insentif Jangka Pendek, yaitu insentif yang diberikan berdasarkan prestasi tahun bersangkutan yang biasanya berbentuk kas.

2) Insentif Jangka Panjang, yaitu insentif yang diberikan dalam bentuk saham.

\section{e. Sistem Kompensasi}

Menurut Anthony \& Govindarajan (2005), terdapat dua pendapat mengenai cara penghargaan tetap (gaji dan tunjangan) dengan penghargaan variabel (insentif) dalam total kompensasi manajer. Sistem tersebut, yaitu:

1) Perusahaan merekrut orang-orang yang dan membayar mereka kemudian mengharapkan mereka untuk bekerja dengan baik. Sistem ini menekankan pada gaji bukan pada insentif. Sistem ini disebut sebagai sistem pembayaran tetap. Sistem pembayaran pada sistem ini tidak didasarkan pada kinerja manajer. Sistem ini memiliki keunggulan, yaitu manajer cenderung berorientasi pada kepentingan jangka panjang perusahaan. Hal tersebut karena manajer dibayar berdasarkan gaji tanpa bonus sehingga tidak akan ambisius pada pencapaian kepentingan jangka pendek perusahaan. Manajer akan lebih berorientasi pada kepentingan jangka panjang yang 
mementingkan kualitas sehingga manajer dapat terus bekerja di perusahaan dan mendapatkan gaji. Walaupun memiliki keunggulan, namun sistem ini juga memiliki kelemahan, yaitu manajer menjadi tidak termotivasi untuk bekerja secara maksimal. Hal tersebut karena pencapaian tujuan apa saja, manajer hanya akan menerima gaji tetap.

2) Perusahaan merekrut orang-orang yang baik lalu mengharapkan mereka dapat bekerja dengan baik dan akan membayar mereka jika memiliki kinerja yang baik. Sistem ini disebut sistem pembayaran berdasarkan kinerja. Sistem ini menekankan pada insentif. Sistem ini memiliki keunggulan karena manajer cenderung termotivasi untuk bekerja secara maksimal untuk mencapai tujuan perusahaan. Hal tersebut karena manajer akan mendapatkan insentif jika manajer berhasil mencapai tujuan tersebut. Walaupun begitu, sistem ini memiliki kelemahan, yaitu manajer lebih berorientasi pada kepentingan jangka pendek perusahaan. Hal tersebut karena manajer memperoleh kompensasi setelah tercapainya tujuan sehingga manajer cenderung termotivasi untuk memaksimalkan insentif dengan mengabaikan kepentingan jangka panjang perusahaan.

\section{Asimetri Informasi}

\section{a.Pengertian Asimetri Informasi}

Dunk (1991) mendefinisikan asimetri informasi sebagai suatu keadaan di mana informasi yang dimiliki bawahan melebihi informasi yang dimiliki atasannya. Informasi tersebut dapat berupa produktivitas 
unit tanggungjawab manajer bawah, tingkat usaha manajer bawah, dan juga sumber daya yang dibutuhkan (Al-Rwita, 2008).

Menurut Anthony \& Govindarajan (2005), asimetri informasi dijelaskan melalui konsep teori agensi. Dalam suatu organisasi perusahaan, principal tidak selalu mengetahui aktivitas agen dan kondisi di unit tanggungjawab agen tersebut. Kondisi ini disebut sebagai asimetri informasi. Karena principal tidak memiliki informasi yang mencukupi mengenai kinerja agen maka principal tidak pernah bisa mengetahui secara pasti bagaimana usaha agen memberikan kontribusinya pada perusahaan.

Perbedaan informasi yang dimiliki antara manajer atas dan manajer bawah membuat manajer bawah memiliki informasi privat karena manajer bawah tahu lebih banyak mengenai tugas di unit tanggungjawabnya. Perbedaan tujuan antara principal dan agen serta adanya kondisi asimetri informasi dapat menyebabkan agen salah menyajikan informasi kepada principal (Anthony \& Govindarajan, 2005).

Shields \& Young (1993) mengemukakan beberapa kondisi perusahaan yang kemungkinan memunculkan informasi asimetri, yaitu: perusahaan yang sangat besar, mempunyai penyebaran secara geografis, memiliki produk yang beragam, dan membutuhkan teknologi.

Informasi privat tidak hanya dimiliki oleh manajer bawah saja, tetapi juga manajer atas (Lau \& Eggleton, 2003; Fisher, 2000). Dalam 
praktik, ada kemungkinan manajer atas memiliki informasi yang lebih dari manajer bawah karena manajer atas memiliki akses ke sistem informasi yang canggih untuk menilai perubahan lingkungan eksternal (Pope, 1984).

\section{b. Jenis Asimetri Informasi}

Asimetri informasi ada dua jenis, yaitu adverse selection dan moral hazard (Faria \& Silva, 2013).

1) Adverse Selection

Adverse selection ditunjukkan dengan perbedaan informasi yang dimiliki antara manajer atas dan manajer bawah. Adanya perbedaan informasi yang dimiliki tersebut membuat manajer bawah dapat menyembunyikan informasi yang dimilikinya dimana informasi ini dapat dimanfaatkan untuk memperoleh keuntungan pribadi. Adverse selection terjadi sebelum disetujuinya kontrak antara manajer atas dan manajer bawah.

\section{2) Moral Hazard}

Moral hazard terjadi ketika principal tidak selalu bisa mengawasi dan mengetahui apa yang dilakukan agennya (manajer bawah) setelah principal mengontrak agen. Masalah dari moral hazard adalah adanya kecenderungan berubahnya perilaku manajer bawah setelah kontrak disetujui manajer atas dan manajer bawah, dimana perubahan perilaku ini menyebabkan kerugian bagi perusahaan karena manajer bawah mengejar keuntungan pribadi. 
Menurut Sutedja (2004), adverse selection memiliki kesamaan dengan moral hazard dalam adanya unsur kesengajaan, namun berbeda dalam hal perencanaan. Dalam adverse selection, pada mulanya manajer bawah akan memberikan informasi yang dimilikinya, tetapi karena manajer atas tidak tahu maka informasi tidak jadi diberikan. Pada moral hazard, manajer bawah sejak awal sudah ada niat untuk tidak memberikan informasi yang dimilikinya kepada manajer atas. Adverse selection lebih terkait pada tidak adanya pengungkapan (disclosure) yang diberikan kepada manajer atas, sedangkan moral hazard terletak pada masalah motivasi dan usaha manajer bawah untuk bertindak yang lebih mengutamakan kepentingannya sendiri.

\section{c. Indikator Asimetri Informasi}

Menurut Dunk (1991), indikator asimetri informasi antara lain:

1) Informasi yang dimiliki bawahan dibandingkan dengan atasan Asimetri informasi ditandai dengan perbedaan informasi yang dimiliki manajer atas dengan manajer bawah. Manajer bawah seringkali memiliki informasi yang lebih banyak mengenai unit tanggungjawabnya daripada manajer atas. Hal tersebut karena manajer bawah terlibat langsung dalam pengoperasian unit tanggungjawab yang di bawahinya.

2) Kinerja potensial

Karena manajer bawah terlibat langsung dalam proses pengoperasian unit tanggungjawabnya maka manajer bawah dapat memperkirakan 
kinerja potensial unit tanggungjawabnya lebih baik daripada manajer atas yang tidak terlibat langsung.

3) Teknis pekerjaan

Manajer bawah lebih mengetahui bagaimana cara unit tanggungjawabnya untuk mencapai tujuan daripada manajer atas.

\section{d. Dampak Asimetri Informasi}

Informasi merupakan komoditas yang sangat penting dalam penyusunan anggaran karena dapat mempengaruhi anggaran yang ditetapkan. Oleh karena itu, sebelum menetapkan anggaran, perusahaan akan mengumpulkan informasi yang berguna untuk menyusun anggaran, namun adanya asimetri informasi membuat perusahaan tidak dapat mengetahui semua informasi yang diperlukan sehingga anggaran yang ditetapkan menjadi tidak sepenuhnya tepat.

Cara mengurangi asimetri informasi dalam penyusunan anggaran maka diberlakukan kebijakan penganggaran partisipatif. Adanya partisipasi anggaran maka diharapkan manajer bawah dapat memberikan informasi yang dimilikinya dalam menyusun anggaran. Namun, dengan adanya partisipasi anggaran dapat memberikan kesempatan bagi manajer bawah untuk melakukan perilaku disfungsional.

Asimetri informasi akan dimanfaatkan manajer bawah untuk melakukan senjangan anggaran dengan memberikan informasi yang tidak benar terkait kemampuan kinerja manajer bawah yang sesungguhnya. Manajer bawah akan menyusun anggaran dengan 
merendahkan kemampuan kinerjanya dengan menetapkan target anggaran yang mudah dicapai sehingga manajer bawah terlihat memiliki kinerja yang baik di mata manajer atas dan juga dapat memperoleh insentif karena berhasil mencapai target anggaran (Young, 1985).

Waller (1988) menyatakan anggaran tidak akan berfungsi sebagai alat perencanaan kegiatan perusahaan dan pengalokasian sumber-sumber daya yang dimiliki dengan efisien tanpa manajer bawah memberikan informasi yang dimilikinya kepada manajer atas. Jika manajer bawah tidak memberikan informasi yang dimilikinya untuk digunakan dalam penyusunan anggaran maka anggaran yang dibuat tidak akan menghasilkan laba yang optimal karena keputusan yang diambil manajer bawah terkait dengan rencana kegiatan tidak tepat dan juga tidak menunjukkan adanya penghematan biaya yang dikeluarkan. Jadi, informasi yang diberikan manajer bawah sangat penting dalam penyusunan anggaran.

\section{Orientasi Etika}

\section{a. Pengertian Orientasi Etika}

Menurut Schlenker \& Forsyth (1977), tiap individu memiliki pandangan yang berbeda mengenai penilaian etis atau tidaknya suatu perilaku. Berdasarkan pernyataan tersebut, Forsyth (1980) mengembangkan penelitian dimana ia mengajukan teori mengenai tipe orientasi etika untuk menjelaskan variasi mengenai penilaian etis pada individu. Ponemon (1991) menjelaskan bahwa orientasi etika pada 
dasarnya adalah pengembangan kemampuan individu untuk mengenali isu-isu mengenai etika dan dilema etika. Orientasi etika merupakan cara pandang individu atas suatu masalah etis yang kemudian mempengaruhi penilaiannya terhadap masalah etis tersebut, lalu akan mempengaruhi motivasi untuk berbuat dan akan diwujudkan dalam perbuatan (Shaub, 1993).

Orientasi etika berhubungan dengan faktor eksternal seperti lingkungan budaya, lingkungan organisasi, dan pengalaman pribadi yang merupakan faktor internal individu tersebut (Hunt\& Vitell, 1986). Norma etis, standar perilaku dalam keluarga, serta standar perilaku dalam komunitas mengarahkan perilaku seseorang untuk mengenali permasalahan mengenai isu-isu etika (Tsalikis \& Fritzsche, 1989).

Orientasi etika terkait dengan kemampuan individu untuk mengevaluasi dan mempertimbangkan nilai etika dalam suatu kasus. Orientasi etika menunjukkan pandangan yang diadopsi individu ketika menghadapi situasi yang membutuhkan pemecahan terkait dengan etika atau disebut dilema etika, dimana individu harus mengambil keputusan antara etis atau tidaknya suatu perilaku (Maiga \& Jacobs, 2008).

\section{b. Karakteristik Orientasi Etika}

Forsyth (1980) membagi orientasi etika menjadi dua karakteristik, yaitu relativisme dan idealisme. Meskipun merupakan dua karakteristik, akan tetapi konsep idealisme dan relativisme bukan 
merupakan hal yang bertolak belakang, tetapi lebih merupakan dua skala yang terpisah yang terkadang saling mempengaruhi pada diri individu.

\section{1) Relativisme}

Relativisme berkaitan dengan batasan individu yang mendasarkan penilaian etis atau tidaknya perilaku pada aturan-aturan moral secara umum. Seseorang yang memiliki relativisme tinggi akan menolak pandangan bahwa penilaian etis atau tidaknya perilaku berdasarkan aturan-aturan secara umum dan lebih meyakini bahwa ada perspektif lain dalam menilai etis atau tidaknya perilaku. Dengan kata lain, individu dengan relativisme tinggi menilai etis atau tidaknya perilaku berdasarkan pertimbangan-pertimbangan personal. Individu dengan relativisme rendah lebih meyakini bahwa penilaian etika berdasarkan pada aturan-aturan secara umum dan meyakini bahwa aturan-aturan tersebut harus diterapkan secara konsisten dan menghiraukan pertimbangan-pertimbangan personal.

\section{2) Idealisme}

Idealisme berkaitan dengan keyakinan individu pada hubungan antara tindakan dengan dampak yang ditimbulkannya. Individu yang memiliki idealisme tinggi meyakini bahwa tindakan yang secara moral benar maka tidak akan merugikan pihak lain, sedangkan tindakan yang secara moral salah maka akan berdampak negatif bagi pihak lain, sedangkan individu dengan idealisme rendah meyakini bahwa tindakan tidak etis dapat berdampak positif dan 
negatif sehingga dibalik dampak negatif yang diterima pihak lain atas tindakan tidak etis maka ada sisi positif dari tindakan tersebut. Menurut Forsyth (1992), idealisme berkaitan dengan tingkatan perhatian individu terhadap kepentingan pihak lain.

\title{
c. Klasifikasi Orientasi Etika
}

\author{
Menurut Forsyth (1980), relativisme berhubungan dengan \\ masalah prinsip moral, sedangkan idealisme berhubungan dengan \\ konsekuensi atau dampak dari suatu tindakan. Relativisme dan idealisme \\ individu dapat tinggi atau rendah. Oleh karena itu, tipe orientasi etika \\ relativisme dan idealisme diklasifikasikan menjadi empat, yaitu \\ subjectivism, absolutism, situationism, dan exceptionism.
}

\section{1) Situationism}

Situationism menunjuk pada individu yang memiliki relativisme dan idealisme tinggi. Situationist menolak aturan moral secara umum pada penilaian etis suatu tindakan karena individu tersebut lebih meyakini bahwa setiap tindakan harus dipertimbangkan etis atau tidaknya menurut perspektif personal.

Selain itu, situationist meyakini bahwa suatu tindakan yang bermoral adalah tindakan yang tidak berdampak buruk bagi pihak tertentu. Jika suatu tindakan menimbulkan dampak negatif bagi pihak tertentu walaupun tindakan tersebut dapat memberikan dampak positif maka tindakan tersebut termasuk tindakan yang tidak etis dan harus dihindari. Karena situationist memiliki relativisme 
tinggi dan idealisme tinggi maka situationist akan melakukan analisis individual terhadap setiap tindakan dalam setiap situasi. Hal tersebut membuat situationist memiliki kemungkinan untuk melakukan tindakan yang etis atau tindakan yang tidak etis.

2) Absolutism

Absolutism menunjuk pada individu yang memiliki relativisme rendah dan idealisme tinggi. Absolutist meyakini adanya aturan moral secara umum pada penilaian etis suatu tindakan dan menolak pendapat bahwa suatu tindakan tersebut dinilai berdasarkan pertimbangan pribadi. Absolutist juga meyakini bahwa suatu tindakan dikatakan etis jika tidak berdampak buruk bagi pihak tertentu. Meyakini aturan moral secara umum dan meyakini bahwa seseorang tidak boleh melakukan tindakan yang dapat memberi dampak negatif pada pihak lain akan membuat absolutist memiliki kecenderungan tinggi untuk tidak melakukan tindakan yang tidak etis.

\section{3) Subjectivism}

Subjectivism menunjuk pada individu yang memiliki relativisme tinggi dan idealisme rendah. Subjectivist menolak aturan moral secara umum mengenai penilaian etis suatu tindakan karena individu tersebut lebih meyakini bahwa setiap tindakan dinilai etis atau tidaknya berdasarkan perspektif personal. Subjectivist juga meyakini bahwa suatu tindakan walau berdampak buruk bagi pihak 
tertentu, namun, tidak dikatakan tidak etis karena tindakan tersebut di sisi lain memberikan dampak positif. Karena subjectivist lebih meyakini pendapat personal daripada aturan moral secara umum ditambah dengan keyakinannya bahwa suatu tindakan boleh dilakukan walaupun berdampak negatif maka subjectivist akan memiliki kecenderungan yang tinggi untuk melakukan tindakan yang tidak etis.

4) Exceptionist

Exceptionist menunjuk pada individu yang memiliki relativisme dan idealisme rendah. Exceptionist meyakini bahwa prinsip moral secara umum digunakan dalam penilaian etis suatu tindakan. Exceptionist juga meyakini bahwa suatu tindakan walau dapat berdampak buruk bagi pihak tertentu dapat dikatakan etis karena tindakan tersebut di sisi lain memberikan dampak positif. Exceptionist bisa melakukan pengecualian terhadap keyakinannya atas aturan moral secara umum karena exceptionist juga meyakini bahwa suatu tindakan boleh dilakukan walau dapat memberikan dampak negatif bagi pihak lain. Hal tersebut dilakukan jika exceptionist menilai bahwa menggunakan pertimbangan persona dinilai lebih cocok untuk menilai etis atau tidaknya suatu tindakan. 


\section{d. Orientasi Etika terhadap Senjangan Anggaran}

Abdullah (2012) melakukan penelitian mengenai pengaruh orientasi etika terhadap senjangan anggaran. Dari penelitian tersebut diperoleh kesimpulan bahwa:

1) Absolutism

Absolutisme berhubungan negatif terhadap senjangan anggaran. Absolutist memiliki kecenderungan yang paling rendah terkait senjangan anggaran dibandingkan situationist, subjectivist, dan exceptionist. Absolutist akan menghindari senjangan anggaran karena meyakini bahwa senjangan anggaran dapat berdampak buruk bagi perusahaan sehingga absolutist menganggap bahwa senjangan anggaran termasuk perbuatan tidak etis.

\section{2) Situationist dan exceptionist}

Situationist dan exceptionist memiliki kecenderungan tingkat menengah terkait senjangan anggaran dibandingkan absolutist dan subjectivist. Situationist menolak aturan moral secara umum dan lebih meyakini pertimbangan personal terkait penilaian etis atau tidaknya suatu tindakan sehingga memiliki kemungkinan untuk menilai senjangan anggaran termasuk tindakan etis, tetapi situationist juga akan menilai senjangan anggaran termasuk tindakan tidak etis karena dapat berdampak buruk bagi perusahaan sehingga situationist juga memiliki kemungkinan untuk menilai senjangan anggaran termasuk tindakan tidak etis. 
Exceptionist meyakini aturan moral secara umum dalam menilai etis atau tidaknya suatu tindakan sehingga memiliki kemungkinan untuk menilai senjangan anggaran termasuk tindakan tidak etis, tetapi exceptionist dapat melakukan pengecualian karena exceptionist juga meyakini bahwa suatu tindakan walaupun berdampak buruk, tetapi di sisi lain dapat berdampak positif sehingga exceptionist memiliki kemungkinan untuk menilai senjangan anggaran termasuk tindakan etis. Karena exceptionist memiliki kemungkinan untuk menilai senjangan anggaran termasuk tindakan etis dan termasuk tindakan tidak etis maka exceptionist akan memiliki kemungkinan untuk memilih salah satu dari penilaian tersebut.

\section{3) Subjectivism}

Subjectivist memiliki kecenderungan yang paling tinggi terkait senjangan anggaran dibandingkan absolutist, situationist, dan exceptionist. Subjectivist menilai senjangan anggaran termasuk tindakan etis karena subjectivist menolak aturan moral secara umum terkait penilaian etis suatu tindakan dan lebih meyakini bahwa tindakan etis dinilai berdasarkan pertimbangan personal, juga meyakini bahwa senjangan anggaran walaupun dapat berdampak buruk bagi perusahaan, namun di sisi lain dapat memberikan dampak positif. 


\section{e. Indikator Orientasi Etika}

Indikator-indikator orientasi etika terdiri dari dua, yaitu indikator relativisme dan idealisme. Menurut Shaub et. al (1993), indikator relativisme dan idealisme sebagai berikut.

1) Relativisme

a) Penolakan aturan moral secara umum untuk menilai tindakan etis atau tidaknya suatu tindakan.

Relativisme adalah suatu sikap penolakan terhadap nilainilai moral yang absolut dalam mengarahkan perilaku. Relativisme menganggap nilai-nilai moral terbatas pada budaya, kelompok, masyarakat, atau organisasi tertentu. Nilai moral di berbagai masyarakat dan kebudayaan tidaklah sama sehingga apalah gunanya bicara mengenai kemutlakan nilai atau norma apabila tiap masyarakat memiliki nilai atau norma yang berbeda.

b) Penilaian etis atau tidaknya suatu tindakan didasarkan pada situasi dan lingkungan.

Relativisme menilai suatu tindakan berdasarkan situasi dan lingkungan yang melingkupinya karena menganggap tidak ada aturan moral yang mutlak sehingga akan lebih baik jika melihat situasi dan lingkungan yang melingkupi.

c) Penggunaan pertimbangan personal untuk menilai suatu tindakan.

Mengingat aturan moral untuk tiap-tiap kelompok, masyarakat, dan organisasi berbeda-beda maka akan lebih baik 
jika suatu tindakan dinilai etis atau tidak berdasarkan pertimbangan personal. Aturan moral dibuat berdasarkan pertimbangan personal sehingga memungkinkan adanya perbedaan pendapat. Oleh karena itu, aturan moral yang dibuat tersebut tidak bisa digunakan untuk menilai tindakan orang lain.

Dengan menggunakan pertimbangan personal maka akan tercipta hubungan yang harmonis antar individu pada kelompok, masyarakat, atau organisasi yang berbeda. Hal tersebut karena relativisme menganggap bahwa dengan menerapkan aturan moral secara absolut akan menimbulkan perbedaan pendapat yang dapat memunculkan konflik.

d) Penilaian etis atau tidaknya suatu tindakan berbeda-beda sehingga tidak ada pendapat mana yang benar.

Relativisme merupakan pendapat bahwa tidak ada standar etika yang pasti benar dan harus diterapkan dalam perusahaan dan dalam masyarakat. Mengingat di setiap lingkungan memiliki kepercayaan etika yang berbeda maka tidak ada cara untuk menentukan suatu tindakan itu secara moral dapat dikatakan benar atau salah. Relativisme mempertimbangkan suatu keadaan ketika menilai suatu tindakan daripada mempertimbangkan aturan etika yang dilanggar sehingga tidak ada aturan etika yang bisa dibentuk untuk menentukan suatu tindakan benar atau salah. 
2) Idealisme

a) Tindakan yang dilakukan tidak boleh merugikan pihak lain sekecil apapun.

Idealisme berpegang teguh pada nilai-nilai moral sehingga tidak mentoleransi tindakan yang dapat merugikan pihak lain sekecil apapun karena bertentangan dengan nilai moral yang dianutnya.

b) Tindakan yang dilakukan tidak boleh mengancam martabat dan kesejahteraan pihak lain.

Idealisme berpegang teguh pada nilai-nilai moral sehingga tidak akan melakukan tindakan yang dapat mengancam martabat dan kesejahteraan pihak lain karena hal tersebut bertentangan dengan nilai moral yang dianutnya.

c) Menyeimbangkan tindakan yang memiliki konsekuensi positif dengan negatif adalah tidak bermoral.

Idealisme menganggap bahwa suatu tindakan tidak boleh merugikan pihak lain sekecil apapun sehingga idealisme akan menolak melakukan tindakan yang dapat merugikan pihak lain walaupun tindakan tersebut berdampak positif.

d) Tindakan yang bermoral adalah tindakan yang ideal.

Idealisme menganggap bahwa suatu tindakan dapat dikatakan bermoral jika tindakan tersebut bersifat ideal, yaitu 
sesuai dengan nilai norma dan tidak memberikan dampak negatif bagi pihak lain.

\section{B. Penelitian yang Relevan}

1. Penelitian yang dilakukan Elizabeth Vyninca Pello (2014) yang berjudul "Pengaruh Asimetri Informasi dan Locus of Control pada Hubungan Antara Penganggaran Partisipatif dengan Senjangan Anggaran” menunjukkan asimetri informasi dan locus of control berhubungan negatif pada hubungan partisipasi anggaran dengan senjangan anggaran. Penelitian yang dilakukan oleh Elizabeth (2014) dan peneliti memiliki perbedaan, antara lain 1) peneliti menggunakan faktor orientasi etika sebagai variabel moderating yang mempengaruhi hubungan asimetri informasi dengan senjangan anggaran; 2) peneliti menggunakan variabel asimetri informasi sebagai variabel independen bukan variabel moderating; 3) peneliti menggunakan metode eksperimen untuk penelitian.

2. Penelitian yang dilakukan Kung \& Huang (2010) yang berjudul “Auditors' Moral Philosophies and Ethical Beliefs", menyatakan bahwa idealisme cenderung berhubungan negatif dengan tndakan tidak etis yang dilakukan auditor, sedangkan relativisme berhubungan positif dengan tindakan yang tidak etis. Penelitian memiliki perbedaan dengan penelitian yang akan dilakukan peneliti, yaitu Kung \& Huang (2010) menggunakan kuesioner untuk mengambil data, sedangkan peneliti menggunakan metode eksperimen; 2) Kung \& Huang (2010) menggunakan sampel auditor, 
sedangkan penelti menggunakan sampel mahasiswa S1 Akuntansi dan Pendidikan Akuntansi Universitas Negeri Yogyakarta.

3. Penelitian yang dilakukan Abdullah (2012) yang berjudul "The Influence of Horizontal Equity, Self Efficacy, and Ethical Position on the Creation of Budgetary Slack”, menyatakan bahwa orientasi etika mempengaruhi senjangan anggaran. Hal ini dibuktikan dengan dua jenis orientasi etika yang memiliki hubungan signifikan terhadap senjangan anggaran dimana relativisme berhubungan positif terhadap senjangan anggaran, sedangkan idealisme berhubungan negatif terhadap senjangan anggaran. Perbedaan antara penelitian Abdullah (2012) dengan penelitian yang akan dilakukan peneliti terletak pada variabel yang digunakan, yaitu peneliti menggunakan variabel orientasi etika yang diinteraksikan dengan asimetri informasi, sedangkan Abdullah (2012) menggunakan orientasi etika yang diinteraksikan dengan horizontal equity dan self efficacy.

4. Penelitian yang dilakukan Tri \& Slamet (2004) yang berjudul "Pengaruh Reputasi, Etika, dan Self-Esteem pada Budgetary Slack", menyatakan bahwa asimetri informasi berpengaruh positif terhadap senjangan anggaran, reputasi dan self-esteem berpengaruh negatif terhadap senjangan anggaran, dan etika tidak berpengaruh terhadap senjangan anggaran. Perbedaan antara penelitian Tri \& Slamet (2004) dengan penelitian yang akan dilakukan peneliti terletak pada variabel yang digunakan. Tri \& Slamet (2004) menggunakan variabel reputasi, etika, dan self-esteem, sedangkan peneliti menggunakan variabel orientasi etika. Tri \& Slamet 
(2004) dan peneliti sama-sama menggunakan variabel asimetri informasi dan melakukan penelitian eksperimental.

5. Penelitian yang dilakukan Stevens (2002) yang berjudul "The Effects of Reputation and Ethics on Budgetary Slack”, menyatakan bahwa reputasi dan etika berhubungan negatif dengan senjangan anggaran. Perbedaan antara penelitian Stevens (2002) dengan penelitian yang akan dilakukan peneliti terletak pada variabel yang digunakan. Stevens (2002) menggunakan variabel reputasi dan etika, sedangkan peneliti menggunakan variabel asimetri informasi dan orientasi etika. Stevens (2002) dan peneliti sama-sama melakukan penelitian eksperimental.

\section{Kerangka Berpikir}

\section{Pengaruh Asimetri Informasi terhadap Senjangan Anggaran}

Manajer atas seringkali kurang memiliki informasi terkait unit tanggungjawab manajer bawah sehingga menyebabkan perbedaan informasi yang dimiliki antara manajer atas dan manajer bawah. Kondisi ini disebut asimetri informasi. Dalam kondisi asimetri informasi, partisipasi anggaran diperlukan dalam penyusunan anggaran karena manajer bawah lebih mengerti dan paham mengenai unit tanggungjawab yang dibawahinya.

Dengan adanya partisipasi anggaran, diharapkan manajer bawah dapat memberikan informasi relevan mengenai unit tanggungjawabnya terkait dengan penyusunan anggaran sehingga anggaran yang dihasilkan sesuai dengan kemampuan yang sebenarnya. Namun, perilaku 
disfungsional manajer bawah terkadang terjadi pada penganggaran partisipastif. Manajer bawah seringkali memanfaatkan adanya asimetri informasi untuk menciptakan senjangan anggaran karena dimotivasi oleh insentif yang diberikan manajer atas jika berhasil mencapai target anggaran.

Senjangan anggaran yang dilakukan manajer bawah dapat dilihat dari tingkatan asimetri informasi. Peneliti membagi tiga kelompok tingkatan asimetri informasi. Pada kondisi tidak ada asimetri informasi maka kesempatan untuk membuat senjangan anggaran sangat kecil karena kinerja manajer bawah diketahui oleh manajer atas sehingga kecenderungan untuk membuat senjangan anggaran akan sangat kecil. Kecenderungan untuk membuat senjangan anggaran direpresentasikan oleh nilai rata-rata senjangan anggaran yang dibuat oleh manajer bawah. Oleh karena kecenderungan untuk membuat senjangan anggaran sangat kecil maka nilai rata-rata senjangan anggaran yang dibuat oleh manajer bawah pada kondisi tidak ada asimetri informasi akan sangat kecil.

Pada kondisi asimetri informasi rendahmaka kesempatan untuk membuat senjangan anggaran kecil karena kinerja manajer bawah diketahui oleh manajer atas, namun tidak semua informasi yang dimiliki manajer bawah diketahui oleh manajer atas sehingga kecenderungan untuk membuat senjangan anggaran akan kecil. Oleh karena kecenderungan untuk membuat senjangan anggaran kecil maka nilai rata-rata senjangan anggaran yang dibuat oleh manajer bawah pada kondisi asimetri informasi 
rendah akan kecil. Jika dibandingkan dengan kecenderungan untuk membuat senjangan anggaran pada kondisi tidak ada asimetri informasi maka kecenderungan untuk membuat senjangan anggaran pada kondisi asimetri informasi rendah lebih besar sehingga nilai rata-rata senjangan anggarannya juga lebih besar.

Pada kondisi asimetri informasi tinggimaka kesempatan untuk membuat senjangan anggaran besar karena kinerja manajer bawah tidak diketahui oleh manajer atas sehingga kecenderungan untuk membuat senjangan anggaran yang dibuat manajer bawah akan lebih besar. Oleh karena kecenderungan untuk membuat senjangan anggaran besar maka nilai rata-rata senjangan anggaran yang dibuat pada kondisi asimetri informasi tinggi juga besar. Berdasarkan pernyataan di atas maka penulis mengajukan hipotesis sebagai berikut:

$\mathrm{H} 1=$ Terdapat perbedaan nilai rata-rata senjangan anggaran pada tingkatan asimetri informasi.

\section{Pengaruh Relativisme pada Hubungan Asimetri Informasi terhadap Senjangan Anggaran}

Walaupun dihadapkan pada kondisi asimetri informasi, terkadang manajer bawah tidak melakukan senjangan anggaran. Hal tersebut salah satunya disebabkan oleh faktor individu. Faktor individu ini salah satunya berhubungan dengan orientasi etika. Orientasi etika berkaitan dengan cara pandang individu atas penilaian etis atau tidaknya suatu perilaku (moral judgement). Ada dua jenis orientasi etika yang mempengaruhi tindakan 
manajer terkait senjangan anggaran, yaitu relativisme dan idealisme. Setiap individu bisa memiliki relativisme dan idealisme tinggi atau rendah. Peneliti membagi masing-masing kelompok tingkatan asimetri informasi menjadi dua tingkatan relativisme.

Individu yang memiliki relativisme tinggiakan menolak aturan moral secara umum dalam menilai suatu tindakan termasuk etis atau tidak karena ia lebih memilih menggunakan pertimbangan-pertimbangan menurut perspektif individu. Oleh karena itu, individu yang memiliki relativisme tinggi akan memiliki kecenderungan yang lebih tinggi dalam menilai senjangan anggaran termasuk perilaku etis karena menolak aturan moral secara umum bahwa senjangan anggaran termasuk tidak etis sehingga kemungkinan individu tersebut untuk melakukan senjangan anggaran lebih tinggi. Karena menilai senjangan anggaran boleh dilakukan maka tingkatan asimetri informasi akan mempengaruhi kecenderungan manajer bawah untuk melakukan senjangan anggaran. Semakin tinggi asimetri informasi maka semakin tinggi pula kecenderungan manajer bawah untuk melakukan senjangan anggaran.

Kecenderungan manajer bawah untuk membuat senjangan anggaran direpresentasikan oleh rata-rata nilai senjangan anggaran yang dibuat masing-masing kelompok tingkatan relativisme. Oleh karena manajer bawah yang memiliki relativisme tinggi memiliki kecenderungan yang lebih besar untuk melakukan senjangan anggaran maka nilai rata-rata senjangan anggaran pada kelompok relativisme tinggi akan lebih besar. 
Sebaliknya, individu yang memiliki relativisme rendah akan meyakini aturan moral secara umum mengenai penilaian etis suatu tindakan. Individu yang memiliki relativisme rendah akan memiliki kecenderungan yang tinggi dalam menilai senjangan anggaran termasuk perilaku tidak etis karena mengikuti aturan moral secara umum yang menyatakan senjangan anggaran termasuk tindakan tidak etis sehingga kemungkinan untuk melakukan senjangan anggaran lebih rendah.

Karena manajer bawah menilai senjangan anggaran termasuk tindakan tidak etis maka tingkatan asimetri informasi tidak akan berpengaruh. Walaupun manajer bawah berada dalam kondisi asimetri informasi tinggi sekalipun, manajer bawah tetap memiliki kecenderungan yang lebih rendah untuk melakukan senjangan anggaran. Manajer bawah yang memiliki relativisme rendah tidak akan memanfaatkan asimetri informasi untuk mendapatkan insentif. Oleh karena manajer bawah yang memiliki relativisme rendah memiliki kecenderungan yang lebih rendah untuk membuat senjangan anggaran maka rata-rata nilai senjangan anggaran pada kelompok relativisme rendah akan lebih rendah. Berdasarkan pernyataan di atas maka penulis mengajukan hipotesis, yaitu: $\mathrm{H} 2$ = Manajer yang memiliki relativisme tinggi akan memiliki rata-rata nilai senjangan anggaran yang lebih tinggi dibandingkan dengan manajer yang memiliki relativisme rendah. 


\section{Pengaruh Idealisme pada Hubungan Asimetri Informasi terhadap Senjangan Anggaran}

Individu yang memiliki idealisme tinggi meyakini bahwa suatu tindakan dikatakan etis jika tidak merugikan pihak lain. Individu tersebut memiliki kecenderungan tinggi dalam menilai senjangan anggaran termasuk tindakan tidak etis karena dapat berdampak buruk bagi perusahaan sehingga kemungkinan untuk melakukan senjangan anggaran lebih rendah.

Karena menilai senjangan anggaran termasuk tindakan tidak etis maka tingkatan asimetri informasi tidak akan berpengaruh pada manajer bawah yang memiliki idealisme tinggi. Walau manajer bawah berada pada kondisi asimetri informasi tinggi sekalipun, kecenderungan untuk melakukan senjangan anggaran akan tetap rendah. Manajer bawah tidak akan memanfaatkan asimetri informasi untuk mendapatkan insentif.

Peneliti membagi masing-masing tingkatan asimetri informasi menjadi dua kelompok tingkatan idealisme, yaitu tinggi dan rendah. Kecenderungan untuk membuat senjangan anggaran direpresentasikan dengan rata-rata nilai senjangan anggaran yang dibuat oleh manajer bawah pada masing-masing kelompok tingkatan idealisme. Oleh karena manajer bawah yang memiliki idealisme tinggi memiliki kecenderungan untuk membuat senjangan anggaran yang lebih rendah maka akan memiliki ratarata nilai senjangan anggaran yang lebih rendah pada kelompok idealisme tinggi. 
Sebaliknya, individu yang memiliki idealisme rendah menilai suatu tindakan dapat dikatakan etis walau memberikan dampak negatif bagi pihak lain karena di samping dampak negatif yang ditimbulkan tindakan tersebut, terdapat dampak positif. Individu yang memiliki idealisme rendah memiliki kecenderungan yang lebih tinggi dalam menilai senjangan anggaran termasuk tindakan etis sehingga kemungkinan untuk melakukan senjangan anggaran lebih tinggi.

Karena menilai senjangan anggaran termasuk tindakan etis maka tingkatan asimetri informasi akan mempengaruhi kecenderungan manajer bawah untuk melakukan senjangan anggaran. Manajer bawah akan memanfaatkan asimetri informasi untuk mendapatkan insentif. Semakin tinggi asimetri informasi maka kecenderungan manajer bawah untuk melakukan senjangan anggaran akan semakin tinggi pula. Oleh karena kecenderungan untuk membuat senjangan anggaran lebih tinggi maka pada kelompok idealisme rendah akan memiliki rata-rata nilai senjangan anggaran yang lebih tinggi. Berdasarkan pernyataan di atas maka penulis mengajukan hipotesis, yaitu:

H3 = Manajer yang memiliki idealisme tinggi akan memiliki ratarata nilai senjangan anggaran yang lebih rendah dibandingkan dengan manajer yang memiliki idealisme rendah. 


\section{Pengaruh Orientasi Etika pada Hubungan Asimetri Informasi terhadap Senjangan Anggaran}

Selain memiliki tingkatan relativisme, individu juga memiliki tingkatan idealisme pada dirinya sehingga orientasi etika merupakan gabungan dari relativisme dan idealisme. Gabungan dari tipe orientasi etika relativisme dan idealisme kemudian diklasifikasikan menjadi empat, yaitu subjectivist, absolutist, situationist, dan exceptionist. Situationist menunjuk pada individu yang memiliki relativisme dan idealisme tinggi. Absolutist menunjuk pada individu yang memiliki relativisme rendah dan idealisme tinggi. Subjectivist menunjuk pada individu yang memiliki relativisme tinggi dan idealisme rendah. Exceptionist menunjuk pada individu yang memiliki relativisme dan idealisme rendah. Peneliti membagi masing-masing kelompok tingkatan asimetri informasi menjadi empat tipe orientasi etika.

Absolutist memiliki kecenderungan yang tinggi untuk menilai senjangan anggaran termasuk tindakan tidak etis. Hal tersebut karena absolutist mengikuti aturan moral secara umum yang menyebutkan senjangan anggaran termasuk tindakan tidak etis dan menganggap senjangan anggaran dapat berdampak buruk bagi perusahaan. Absolutist menilai senjangan anggaran termasuk tindakan tidak etis sehingga akan memiliki kecenderungan yang rendah untuk melakukan senjangan anggaran. 
Karena menilai senjangan anggaran termasuk tindakan tidak etis maka tingkatan asimetri informasi tidak akan berpengaruh pada absolutist. Walaupun dihadapkan pada kondisi asimetri tinggi sekalipun, absolutist akan tetap memiliki kecenderungan yang rendah untuk melakukan senjangan anggaran. Absolutist tidak akan memanfaatkan asimetri informasi untuk mendapatkan insentif.

Kecenderungan untuk membuat senjangan anggaran direpresentasikan oleh rata-rata nilai senjangan anggaran yang dibuat oleh manajer bawah pada masing-masing kelompok orientasi etika. Oleh karena absolutist memiliki kecenderungan yang rendah untuk membuat senjangan anggaran maka rata-rata nilai senjangan anggaran pada kelompok absolutist akan lebih rendah.

Subjectivist memiliki kecenderungan yang tinggi untuk menilai senjangan anggaran termasuk tindakan etis. Hal tersebut karena subjectictivist menolak aturan umum dengan memilih untuk melakukan pertimbangan berdasarkan pendapat personal untuk menilai etis atau tidaknya senjangan anggaran dan menganggap bahwa senjangan anggaran boleh dilakukan walaupun dapat berdampak buruk bagi perusahaan. Subjectivist menilai senjangan anggaran termasuk tindakan etis sehingga akan memiliki kecenderungan yang tinggi untuk melakukan senjangan anggaran.

Karena menilai senjangan aggaran termasuk tindakan etis maka tingkatan asimetri informasi akan mempengaruhi kecenderungan 
subjectivist untuk melakukan senjangan anggaran. Semakin tinggi asimetri informasi maka semakin tinggi pula kecenderungan subjectivist untuk melakukan senjangan anggaran. Subjectivist akan memanfaatkan asimetri informasi untuk mendapatkan insentif. Oleh karena subjectivist memiliki kecenderungan untuk membuat senjangan anggaran yang lebih tinggi maka pada kelompok subjectivist akan memiliki nilai rata-rata nilai senjangan anggaran yang lebih tinggi.

Situationist meyakini bahwa suatu tindakan dinilai etis atau tidaknya berdasarkan pertimbangan personal dan meyakini bahwa suatu tindakan tidak boleh memberikan dampak buruk bagi perusahaan. Karena keyakinannya tersebut maka situationist memiliki kemungkinan untuk melakukan senjangan anggaran atau tidak melakukan senjangan anggaran.

Exceptionist meyakini bahwa suatu tindakan dinilai etis atau tidaknya berdasarkan aturan moral secara umum dan meyakini bahwa suatu tindakan boleh dilakukan walaupun dapat memberikan dampak buruk bagi perusahaan, karena dibalik dampak buruk tersebut ada dampak positifnya. Exceptionist bisa melakukan pengecualian untuk menggunakan pertimbangan pribadi karena exceptionist juga meyakini bahwa suatu tindakan boleh dilakukan walaupun dapat berdampak buruk bagi pihak lain dimana hal tersebut bertentangan dengan aturan moral secara umum. Karena keyakinannya tersebut maka exceptionist memiliki kemungkinan untuk melakukan senjangan anggaran atau tidak melakukannya. 
Tingkatan asimetri informasi memiliki kemungkinan dapat atau tidak dapat mempengaruhi kecenderungan situationist dan exceptionist untuk melakukan senjangan anggaran. Situationist dan exceptionist memiliki kemungkinan untuk memanfaatkan atau tidak memanfaatkan asimetri informasi untuk mendapatkan insentif. Oleh karena situationist dan exceptionist memiliki kemungkinan untuk membuat senjangan anggaran atau tidak maka pada kelompok situationist dan exceptionist akan memiliki rata-rata nilai senjangan anggaran yang tidak terlalu rendah ataupun tidak terlalu tinggi. Berdasarkan pernyataan di atas maka peneliti mengajukan hipotesis, yaitu:

$\mathrm{H} 4=$ Terdapat perbedaan rata-rata nilai senjangan anggaran pada tingkatan asimetri informasi berdasarkan orientasi etika.

\section{Paradigma Penelitian}

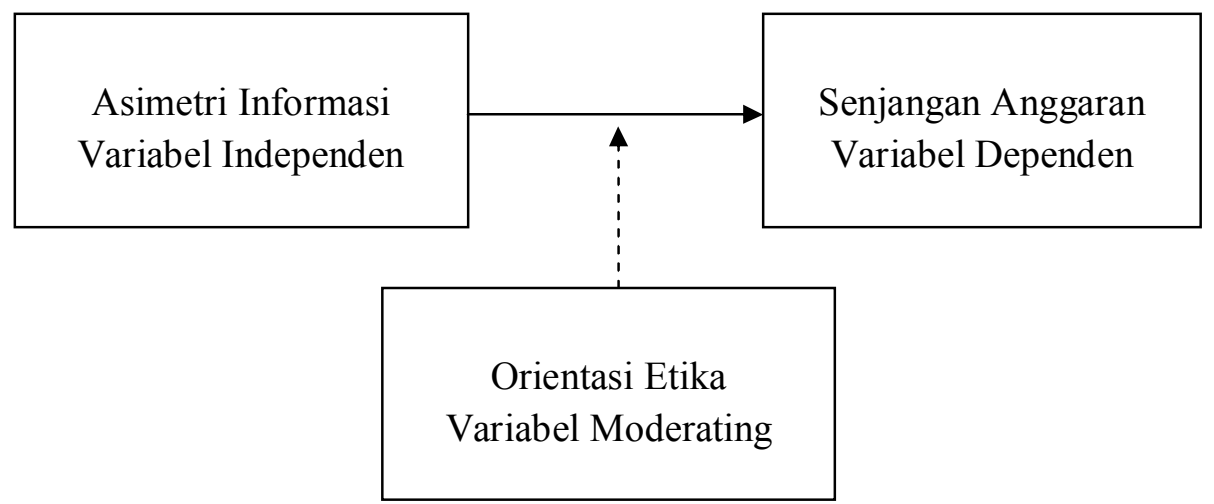

Gambar 1. Paradigma Penelitian

Keterangan :

$\longrightarrow=$ Pengaruh variabel independen (asimetri informasi) terhadap variabel dependen (senjangan anggaran) 


\section{= Pengaruh variabel moderating (orientasi etika) terhadap hubungan variabel independen dengan variabel dependen.}

\section{Hipotesis Penelitian}

Hipotesis-hipotesis yang diajukan dalam penelitian ini antara lain:

H1 = Terdapat perbedaan rata-rata nilai senjangan anggaran pada tingkatan asimetri informasi.

$\mathrm{H} 2$ = Manajer yang memiliki relativisme tinggi akan memiliki rata-rata nilai senjangan anggaran yang lebih tinggi dibandingkan dengan manajer yang memiliki relativisme rendah.

H3 = Manajer yang memiliki idealisme tinggi akan memiliki rata-rata nilai senjangan anggaran yang lebih rendah dibandingkan dengan manajer yang memiliki idealisme rendah.

H4 = Terdapat perbedaan rata-rata nilai senjangan anggaran pada tingkatan asimetri informasi berdasarkan orientasi etika. 


\section{BAB III}

\section{METODE PENELITIAN}

\section{A. Desain Penelitian}

Penelitian yang akan dilakukan merupakan penelitian eksperimental. Desain eksperimen $3 \mathrm{X} 2$ untuk pengaruh faktor asimetri informasi dan relativisme terhadap senjangan anggaran dan juga pengaruh faktor asimetri informasi dan idealisme. Desain eksperimen $3 \mathrm{X} 4$ untuk meneliti pengaruh asimetri informasi dan orientasi etika terhadap senjangan anggaran. Peneliti memanipulasi asimetri informasi menjadi tiga tingkatan dan mengukur orientasi etika menggunakan kuesioner. Pembagian tugas eksperimen dilakukan secara acak (randomly assigned) sehingga kelompok-kelompok tersebut dapat dibandingkan (Imam, 2011). Penelitian ini bertujuan untuk menganalis pengaruh asimetri informasi sebagai variabel independen terhadap senjangan anggaran sebagai variabel dependen dengan dan orientasi etika sebagai variabel moderating. Berdasarkan jenis data yang digunakan, maka penelitian ini termasuk penelitian kuantitatif karena mengacu pada perhitungan data-data berupa angka-angka.

Tabel 1. Desain Eksperimen Pengaruh Asimetri Informasi terhadap Senjangan Anggaran

\begin{tabular}{|l|c|c|c|}
\hline & $\begin{array}{c}\text { Tidak Ada } \\
\text { Asimetri } \\
\text { Informasi }\end{array}$ & $\begin{array}{c}\text { Asimetri } \\
\text { Informasi } \\
\text { Rendah }\end{array}$ & $\begin{array}{c}\text { Asimetri } \\
\text { Informasi } \\
\text { Tinggi }\end{array}$ \\
\hline Treatment & Kasus 1 & Kasus 2 & Kasus 3 \\
\hline
\end{tabular}

Sumber: Data primer diolah (2014) 
Tabel 2. Desain Eksperimen Pengaruh Asimetri Informasi dan Relativisme terhadap Senjangan Anggaran

\begin{tabular}{|l|c|c|c|}
\hline & $\begin{array}{c}\text { Tidak Ada } \\
\text { Asimetri } \\
\text { Informasi }\end{array}$ & $\begin{array}{c}\text { Asimetri } \\
\text { Informasi } \\
\text { Rendah }\end{array}$ & $\begin{array}{c}\text { Asimetri } \\
\text { Informasi } \\
\text { Tinggi }\end{array}$ \\
\hline Relativisme Tinggi & Kasus 1 & Kasus 2 & Kasus 3 \\
\hline Relativisme Rendah & Kasus 1 & Kasus 2 & Kasus 3 \\
\hline
\end{tabular}

Sumber: Data primer diolah (2014)

Tabel 3. Desain Eksperimen Pengaruh Asimetri Informasi dan Idealisme terhadap Senjangan Anggaran

\begin{tabular}{|l|c|c|c|}
\hline & $\begin{array}{c}\text { Tidak Ada } \\
\text { Asimetri } \\
\text { Informasi }\end{array}$ & $\begin{array}{c}\text { Asimetri } \\
\text { Informasi } \\
\text { Rendah }\end{array}$ & $\begin{array}{c}\text { Asimetri } \\
\text { Informasi } \\
\text { Tinggi }\end{array}$ \\
\hline Idealisme Tinggi & Kasus 1 & Kasus 2 & Kasus 3 \\
\hline Idealisme Rendah & Kasus 1 & Kasus 2 & Kasus 3 \\
\hline
\end{tabular}

Sumber: Data primer diolah (2014)

Tabel 4. Desain Eksperimen Pengaruh Asimetri Informasi dan Orientasi Etika terhadap Senjangan Anggaran

\begin{tabular}{|l|c|c|c|}
\hline & $\begin{array}{c}\text { Tidak Ada } \\
\text { Asimetri } \\
\text { Informasi }\end{array}$ & $\begin{array}{c}\text { Asimetri } \\
\text { Informasi } \\
\text { Rendah }\end{array}$ & $\begin{array}{c}\text { Asimetri } \\
\text { Informasi } \\
\text { Tinggi }\end{array}$ \\
\hline Exceptionist & Kasus 1 & Kasus 2 & Kasus 3 \\
\hline Absolutist & Kasus 1 & Kasus 2 & Kasus 3 \\
\hline Subjectivist & Kasus 1 & Kasus 2 & Kasus 3 \\
\hline Situasionist & Kasus 1 & Kasus 2 & Kasus 3 \\
\hline
\end{tabular}

Sumber: Data primer diolah (2014)

Partisipan yang mendapat kasus 1 adalah partisipan yang menerima perlakuan tidak ada asimetri informasi, partisipan yangmendapat kasus 2 adalah partisipan yang menerima perlakuan asimetri informasi rendah, sedangkan partisipan yang mendapat kasus 3 adalah partisipan yang menerima perlakuan asimetri informasi tinggi.

\section{B. Kasus Eksperimen}

Pada eksperimen ini, partisipan berperan sebagai manajer bawah bagian produksi di PT Maju Jaya, perusahaan yang memproduksi pesawat terbang kertas. 
Sebagai manajer bawah bagian produksi, partisipan bertugas untuk membuat anggaran produksi dimana partisipan diharuskan untuk membuat target produksi yang akan diajukan kepada manajer atas.

Agar partisipan dapat menentukan target yang diajukan maka partisipan diharuskan membuat tugas produksi 1,2 , dan 3. Tugas produksi dilakukan tiga kali untuk melihat konsistensi partisipan dalam membuat pesawat terbang kertas. Setelah partisipan menyelesaikan tugas produksi 1, 2, dan 3, partisipan diminta menuliskan hasilnya di angket yang telah disediakan peneliti.

Untuk memotivasi manajer bawah agar bisa melampaui target produksi, manajer atas akan memberikan kompensasi dengan menambah gaji tetap manajer bawah dengan insentif. Jika manajer bawah tidak bisa melampaui target produksi maka manajer bawah hanya akan menerima gaji tetap saja.

Dalam eksperimen, partisipan dikelompokkan menurut tingkatan asimetri informasi, yaitu tidak ada asimetri informasi, asimetri informasi rendah, dan asimetri informasi tinggi. Pada kelompok tidak ada asimetri informasi, partisipan diminta untuk menyerahkan hasil tugas produksi 1, 2, dan 3. Pada kelompok asimetri informasi rendah, partisipan hanya menyerahkan hasil tugas produksi 1 , dan pada kelompok asimetri informasi tinggi, partisipan tidak menyerahkan hasil tugas produksi 1, 2, dan 3 .

Setelah partisipan mengetahui kemampuan kinerjanya, insentif yang akan diberikan manajer atas, dan kondisi asimetri informasi maka partisipan diminta untuk menentukan target produksi kepada manajer atas. Partisipan lalu diminta mengisi kuesioner orientasi etika untuk melihat tipe orientasi etikanya. Hal 
tersebut dilakukan untuk mengetahui kecenderungan partisipan sebagai manajer bawah dalam membuat senjangan anggaran.

\section{Prosedur Penelitian}

Untuk mengetahui perilaku manajer bawah, eksperimen ini dibagi menjadi sepuluh tahap, antara lain:

1. Membagi angket dan kuesioner penelitian kepada partisipan.

Peneliti masuk ke kelas partisipan lalu membagikan angket treatment, kuesioner orientasi etika, dan kertas untuk membuat pesawat terbang kertas kepada partisipan secara acak. Setiap partisipan ada yang mendapat kelompok perlakuan tidak ada asimetri informasi atau asimetri informasi rendah, atau asimetri informasi tinggi.

2. Penjelasan mengenai penelitian yang akan dilakukan.

Peneliti menjelaskan maksud penelitian dan bagaimana cara mengisi angket treatment agar partisipan paham apa yang harus dilakukannya selama penelitian.

3. Partisipan mengisi data demografis.

Partisipan diminta untuk mengisi data demografis seperti, nama, program studi, jenis kelamin, umur, angkatan, mata kuliah yang sudah lulus, dan IPK.

4. Melakukan tugas produksi 1 dalam jangka waktu 2 menit.

Partisipan diminta mengerjakan tugas produksi 1 selama 2 menit dengan menggunakan kertas yang sudah diberikan peneliti. Setelah partisipan 
selesai menuliskan tugas produksi, partisipan diminta menuliskan hasil tugas produksi 1 pada angket yang telah diberikan peneliti.

5. Melakukan tugas produksi 2 dalam jangka waktu 2 menit. Partisipan diminta mengerjakan tugas produksi 2 selama 2 menit dengan menggunakan kertas yang sudah diberikan peneliti. Setelah partisipan selesai menuliskan tugas produksi, partisipan diminta menuliskan hasil tugas produksi 2 pada angket yang telah diberikan peneliti.

6. Melakukan tugas produksi 3 dalam jangka waktu 2 menit.

Partisipan diminta mengerjakan tugas produksi 3 selama 2 menit dengan menggunakan kertas yang sudah diberikan peneliti. Setelah partisipan selesai menuliskan tugas produksi, partisipan diminta menuliskan hasil tugas produksi 3 pada angket yang telah diberikan peneliti.

7. Treatment pada masing-masing kelompok perlakuan.

Setelah menyelesaikan tugas produksi 1, 2, dan 3, partisipan diminta membaca kasus secara seksama untuk masing-masing kelompok perlakuan asimetri informasi.

8. Partisipan diminta menentukan target dalam menyelesaikan tugas produksi selama 2 menit selanjutnya yang akan diajukan kepada atasan.

Setelah membaca kasus perlakuan, partisipan diminta menentukan target selama 2 menit selanjutnya yang akan diajukan kepada atasan berdasarkan kemampuan kinerja tugas produksi 1, 2, dan 3, insentif, dan kondisi asimetri informasi. 
9. Pengisian manipulation check.

Setelah menentukan target produksi, partisipan diminta mengisi manipulation check untuk mengetahui pemahaman partisipan terkait kasus perlakuan yang diberikan. Ada 8 pertanyaan yang diberikan peneliti dimana partisipan diminta untuk menjawab benar atau salah sesuai pertanyaan yang diberikan.

10. Pengisian kuesioner orientasi etika.

Partisipan diminta untuk mengisi kuesioner orientasi etika yang dikembangkan oleh Forsyth (1980) untuk mengetahui tipe orientasi etika partisipan.

\section{Definisi Operasional Variabel}

Variabel penelitian adalah suatu atribut atau sifat atau nilai dari orang, objek, atau kegiatan yang mempunyai variasi tertentu yang ditetapkan oleh peneliti untuk dipelajari dan ditarik kesimpulannya (Sugiyono, 2007). Variabel yang digunakan dalam penelitian ini terdiri dari tiga jenis yaitu variabel dependen, variabel independen, dan variabel moderating. Variabel dependen dalam penelitian ini adalah senjangan anggaran, variabel independen dalam penelitian ini adalah asimetri informasi, sedangkan variabel moderating dalam penelitian ini adalah orientasi etika (relativisme dan idealisme). 


\section{Variabel Dependen}

Menurut Sugiyono (2007), variabel dependen merupakan variabel yang dipengaruhi atau yang menjadi akibat karena adanya variabel bebas. Variabel dependen dalam penelitian ini adalah senjangan anggaran.

Senjangan anggaran adalah perbedaan antara jumlah anggaran yang diajukan dengan estimasi terbaik (Anthony \& Govindarajan, 2005). Senjangan anggaran menurut Kren (2003), ditunjukkan dengan menyajikan biaya lebih besar dari yang seharusnya dibutuhkan atau menyajikan pendapatan lebih rendah dari yang seharusnya bisa diperoleh sehingga dapat dikatakan manajer bawah menurunkan kapabilitas/kemampuan kinerja dari kemampuan yang sebenarnya.

Senjangan anggaran pada penelitian ini termasuk data interval. Senjangan anggaran diketahui dengan melihat perbedaan antara expected performance dengan proyeksi kemampuan partisipan dalam menyelesaikan tugas produksi yang diajukan. Untuk menghitung expected performance, digunakan rumus berikut (Stevens, 2002; Nugrahani \& Sugiri, 2004; Delli \& Ertambang, 2008):

$$
\text { Expected Performance }=\frac{\text { Hasil Produksi 1 }+ \text { Hasil Produksi } 2}{2} .
$$

Untuk mengetahui nilai senjangan anggaran, digunakan rumus (Stevens, 2002; Nugrahani \& Sugiri, 2004; Delli \& Ertambang, 2008):

$$
\text { Budgetary Slack }=\frac{\text { Hasil Produksi 3 - Target Produksi }}{\text { Expected Performance }}
$$




\section{Variabel Independen}

Menurut Sugiyono (2007), variabel independen atau variabel bebas adalah variabel yang mempengaruhi atau menjadi sebab perubahannya atau timbulnya variabel dependen (terikat). Variabel independen dalam penelitian ini adalah asimetri informasi.

Asimetri informasi adalah kondisi dimana dalam suatu organisasi perusahaan, manajer atas tidak selalu mengetahui aktivitas manajer bawah dan kondisi di unit tanggungjawab agen tersebut. Karena manajer atas tidak memiliki informasi yang mencukupi mengenai kinerja manajer bawah maka manajer atas tidak pernah bisa mengetahui secara pasti bagaimana usaha manajer bawah memberikan kontribusinya pada perusahaan.

Asimetri informasi dalam penelitian ini termasuk kategori nominal. Peneliti akan membagi asimetri informasi menjadi tiga tingkatan, yaitu kondisi tidak ada asimetri informasi, asimetri informasi rendah, dan asimetri informasi tinggi. Hal ini dilakukan untuk membedakan pengaruhnya terhadap senjangan anggaran. Penelitian ini mengartikan asimetri informasi, yaitu informasi yang diketahui oleh manajer atas terhadap kemampuan produksi manajer bawah, yang dikelompokkan dalam tiga tingkat, yaitu:

1) Kelompok tanpa asimetri informasi yaitu manajer bawah memberikan informasi hasil produksi dari tugas produksi pertama sampai ketiga kepada manajer atas. Pada kondisi tidak terdapat asimetri informasi, manajer atas mengetahui kemampuan kinerja manajer bawah dari informasi produksi

yang diberikan manajer bawah. Manajer atas dapat mengevaluasi secara 
akurat target produksi yang diajukan manajer bawah sehingga ketika manajer bawah menentukan target produksi di bawah kemampuan kinerja yang sesungguhnya maka manajer atas akan mengetahuinya.

2) Kelompok asimetri informasi rendah, dimana manajer bawah memberi informasi hasil produksi 1 , tetapi tidak memberikan laporan hasil produksi 2 dan 3. Dalam asimetri informasi rendah, manajer atas tidak mengetahui kemampuan kinerja manajer bawah pada tugas produksi 2 dan 3, tetapi manajer atas dapat mengestimasi kemungkinan hasil produksi 2 dan 3 berdasar hasil produksi 1 , namun estimasi tersebut bisa saja tidak akurat sehingga menyebabkan manajer atas kurang bisa mengevaluasi target produksi yang diajukan manajer bawah. Karena manajer atas kurang bisa mengevaluasi secara akurat target produksi yang diajukan manajer bawah maka ketika manajer bawah menentukan target di bawah kemampuan kinerja sesungguhnya, ada kemungkinan manajer atas tidak mengetahuinya.

3) Kelompok asimetri informasi tinggi, dimana manajer bawah tidak memberi informasi hasil produksi 1 sampai 3. Manajer atas sulit untuk mengetahui kemampuan produksi yang sebenarnya dari manajer bawah karena tidak mengetahui hasil produksi 1 sampai 3. Karena manajer bawah tidak menyerahkan hasil tugas produksi 1 sampai 3, manajer atas menjadi tidak bisa mengevaluasi secara akurat target produksi yang diajukan manajer bawah sehingga ketika manajer bawah menentukan target 
produksi di bawah kemampuan kinerja sesungguhnya, manajer atas tidak mengetahuinya.

Semua kelompok asimetri informasi diberikan informasi mengenai skema insentif sebagai metode pembayaran kepada manajer bawah. Penelitian ini menggunakan perhitungan insentif Fixed Pay Plus-Bonus (FPB) sebagai metode pembayaran pada tugas produksi. FPB adalah pembayaran manajer bawah dengan gaji tetap dan jika hasil produksi manajer bawah melebihi yang ditargetkan akan menerima bonus, tetapi jika hasil produksinya kurang dari target, maka manajer bawah hanya menerima gaji tetap. Metode tersebut pernah dilakukan oleh Fisher et al. (2000), Stevens (2002), Tri \& Slamet (2004), dan Delli \& Ertambang, (2008). Rumus perhitungan insentif FPB adalah:

$$
\begin{aligned}
& P=A+\left\{\operatorname{ax}\left(Y^{\prime}-Y^{\prime \prime}\right)\right\}, \text { jika } Y^{\prime} \geq Y^{\prime} \\
& P=A, \text { jika } Y^{\prime}<Y^{\prime}
\end{aligned}
$$

Keterangan:

$\mathrm{P} \quad=$ Total kompensasi yang diterima manajer bawah

A $\quad=$ Gaji tetap yang diterima manajer bawah

a $\quad=$ Bonus tiap unit

$\mathrm{Y}^{\prime} \quad=$ Jumlah produksi sesungguhnya yang dihasilkan

Y” = Target produksi yang diajukan oleh manajer bawah

\section{Variabel Moderating}

Variabel moderating adalah variabel yang berfungsi untuk mempengaruhi hubungan baik memperkuat atau memperlemah antara variabel 
independen dan variabel dependen (Anwar, 2013). Variabel moderating dalam penelitian ini adalah orientasi etika.

Orientasi etika merupakan cara pandang individu atas suatu masalah etis yang kemudian mempengaruhi penilaiannya terhadap masalah etis tersebut, lalu akan mempengaruhi motivasi untuk berbuat dan akan diwujudkan dalam perbuatan (Shaub, 1993). Ponemon (1991) menjelaskan bahwa orientasi etika pada dasarnya adalah pengembangan kemampuan individu untuk mengenali isu-isu mengenai etika dan dilema etika. Orientasi etika terkait dengan kemampuan individu untuk mengevaluasi dan mempertimbangkan nilai etika dalam suatu kasus. Orientasi etika menunjukkan pandangan yang diadopsi individu ketika menghadapi situasi yang membutuhkan pemecahan terkait dengan etika atau dilema etika, dimana individu harus mengambil keputusan antara etis atau tidaknya suatu perilaku.

Forsyth (1980) membagi orientasi etika menjadi dua komponen, yaitu relativisme dan idealisme. Idealisme dan relativisme pada individu dapat tinggi atau rendah. Relativisme berkaitan dengan batasan individu yang mendasarkan penilaian etis atau tidaknya perilaku pada aturan moral secara umum, sedangkan idealisme berkaitan dengan keyakinan individu pada hubungan antara tindakan dengan dampak yang ditimbulkannya. Orientasi etika pada penelitian ini termasuk kategori nominal.

Untuk mengetahui tipe orientasi etika, peneliti menggunakan kuesioner yang dikembangkan oleh Forsyth (1980). Peneliti menggunakan kuesioner yang dikembangkan Forsyth (1980) karena kuesioner tersebut telah banyak 
digunakan seperti, Abdullah (2012), Indira (2011), Muthmainah (2006) dan memiliki nilai reliabilitas tinggi. Kuesioner tersebut terdiri dari 10 pertanyaan untuk mengukur relativisme, dan 10 pertanyaan untuk mengukur idealisme.

Indikator untuk kuesioner idealisme berkaitan dengan 1) tindakan yang dilakukan tidak boleh merugikan orang lain sekecil apapun; 2) tindakan yang dilakukan tidak boleh mengancam martabat dan kesejahteraan pihak lain; 3) menyeimbangkan tindakan yang memiliki konsekuensi positif dengan negatif adalah tidak bermoral; 4) tindakan yang bermoral adalah tindakan yang ideal.

Indikator untuk kuesioner relativisme berkaitan dengan 1) penolakan aturan moral secara umum untuk menilai tindakan etis atau tidaknya suatu tindakan; 2) penilaian etis atau tidaknya suatu tindakan didasarkan pada situasi dan lingkungan; 3) penggunaan pertimbangan personal untuk menilai suatu tindakan; 4) penilaian etis atau tidaknya suatu tindakan berbeda-beda sehingga tidak ada pendapat mana yang benar.

Untuk menentukan tingkatan relativisme dan idealisme partisipan, peneliti menggunakan nilai median sebagai cut-off (Forsyth \& Nye, 1990; Abdullah, 2012). Skor yang berada di atas nilai median maka termasuk relativisme tinggi atau idealisme tinggi, sedangkan skor yang berada di bawah nilai median maka termasuk relativisme rendah atau idealisme rendah.

\section{E. Populasi}

Populasi adalah wilayah generalisasi yang terdiri atas objek atau subjek yang mempunyai kualitas dan karakteristik tertentu yang ditetapkan oleh peneliti untuk dipelajari dan kemudian ditarik kesimpulannya (Sugiyono, 2007). Populasi 
dalam penelitian ini adalah mahasiswa S1 Akuntansi Universitas Negeri Yogyakarta angkatan 2010 dan 2011 angkatan 2011 yang berjumlah 113 mahasiswa yang terdiri dari 37 mahasiswa Akuntansi angkatan 2010 kelas A, 44 mahasiswa Akuntansi angkatan 2011 kelas A, dan 32 mahasiswa Akuntansi angkatan 2011 kelas B, serta mahasiswa Pendidikan Akuntansi angkatan 2011 yang berjumlah 96 mahasiswa yang terdiri dari 45 mahasiswa kelas A dan 51

mahasiswa kelas B. Total populasi mahasiswa Akuntansi dan Pendidikan Akuntansi adalah 209 orang.

\section{F. Sampel}

Sampel adalah bagian dari jumlah dan karakteristik yang dimiliki oleh populasi (Sugiyono,2007). Metode pengambilan sampel yang digunakan dalam penelitian ini adalah purposive sampling, yaitu partisipan yang dipilih memiliki kriteria tertentu. Sampel dalam penelitian ini adalah mahasiswa S1 Akuntansi dan Pendidikan Akuntansi yang telah lulus mata kuliah Akuntansi Manajemen atau Sistem Pengendalian Manajemen atau Penganggaran. Kriteria tersebut diambil karena mahasiswa yang telah lulus salah satu mata kuliah tersebut dianggap sudah memiliki pengetahuan cukup mengenai penyusunan anggaran dan mengerti mengenai senjangan anggaran.

Menurut Gay dalam Anwar (2013) menyatakan bahwa penelitian eksperimental melibatkan minimal 15 sampel untuk tiap-tiap kelompok perlakuan sehingga akan dibutuhkan total sampel minimal sebanyak 45 sampel untuk kelompok perlakuan tidak ada asimetri informasi, asimetri informasi rendah, dan asimetri informasi tinggi. 


\section{G. Teknik Pengumpulan Data}

Sumber data yang digunakan adalah data primer, yaitu data yang diperoleh secara langsung dari sumber asli atau pihak pertama (Arfan, 2008). Adapun metode yang digunakan untuk mengumpulkan data primer dalam peneltian ini adalah metode eksperimental dengan menggunakan kuesioner dan manipulasi pada subjek penelitian. Kelompok perlakuan ditentukan secara acak sehingga setiap partisipan memiliki kesempatan yang sama untuk berada pada kelompok perlakuan tertentu.

Teknik pengumpulan data dalam penelitian ini adalah respon dari partisipan. Partisipan diminta menuliskan hasil tugas produksi, menuliskan target anggaran pada angket yang telah diberikan kepada partisipan, dan juga diminta mengisi kuesioner orientasi etika. Setelah itu, peneliti menghitung senjangan anggaran yang dilakukan partisipan dengan menghitung rata-ratanya.

\section{Tabel 5. Kisi-Kisi Variabel Penelitian}

\begin{tabular}{|c|c|c|c|}
\hline No & Variabel & Penjelasan/Indikator & Kasus \\
\hline 1. & $\begin{array}{l}\text { Senjangan } \\
\text { Anggaran }\end{array}$ & $\begin{array}{l}\text { Senjangan anggaran ditandai dengan target yang } \\
\text { ditetapkan partisipan dibawah kemampuan } \\
\text { sebenarnya. Senjangan anggaran dihitung dengan } \\
\text { rumus : } \\
\text { Budgetary Slack }=\frac{\text { Hasil Produksi3-TargetProduksi }}{\text { ExpectedPerformane }} \\
\text { Expected Performance }=\frac{\text { Hasil Produksil }+ \text { Hasil Produksi2 }}{2}\end{array}$ & $\begin{array}{ll}\text { Kasus } & 1, \\
\text { Kasus } & 2, \\
\text { Kasus } & 3\end{array}$ \\
\hline 2. & $\begin{array}{l}\text { Asimetri } \\
\text { Informasi }\end{array}$ & $\begin{array}{l}\text { Tidak Ada Asimetri Informasi } \\
\text { - Partisipan sebagai manajer bawah diminta } \\
\text { untuk membuat pesawat terbang dari kertas } \\
\text { lipat untuk tugas produksi } 1,2 \text {, dan } 3 . \\
\text { Partisipan diberi informasi bahwa mereka } \\
\text { diminta menyerahkan laporan hasil } \\
\text { produksi dari ketiga tugas produksi kepada }\end{array}$ & Kasus 1 \\
\hline
\end{tabular}




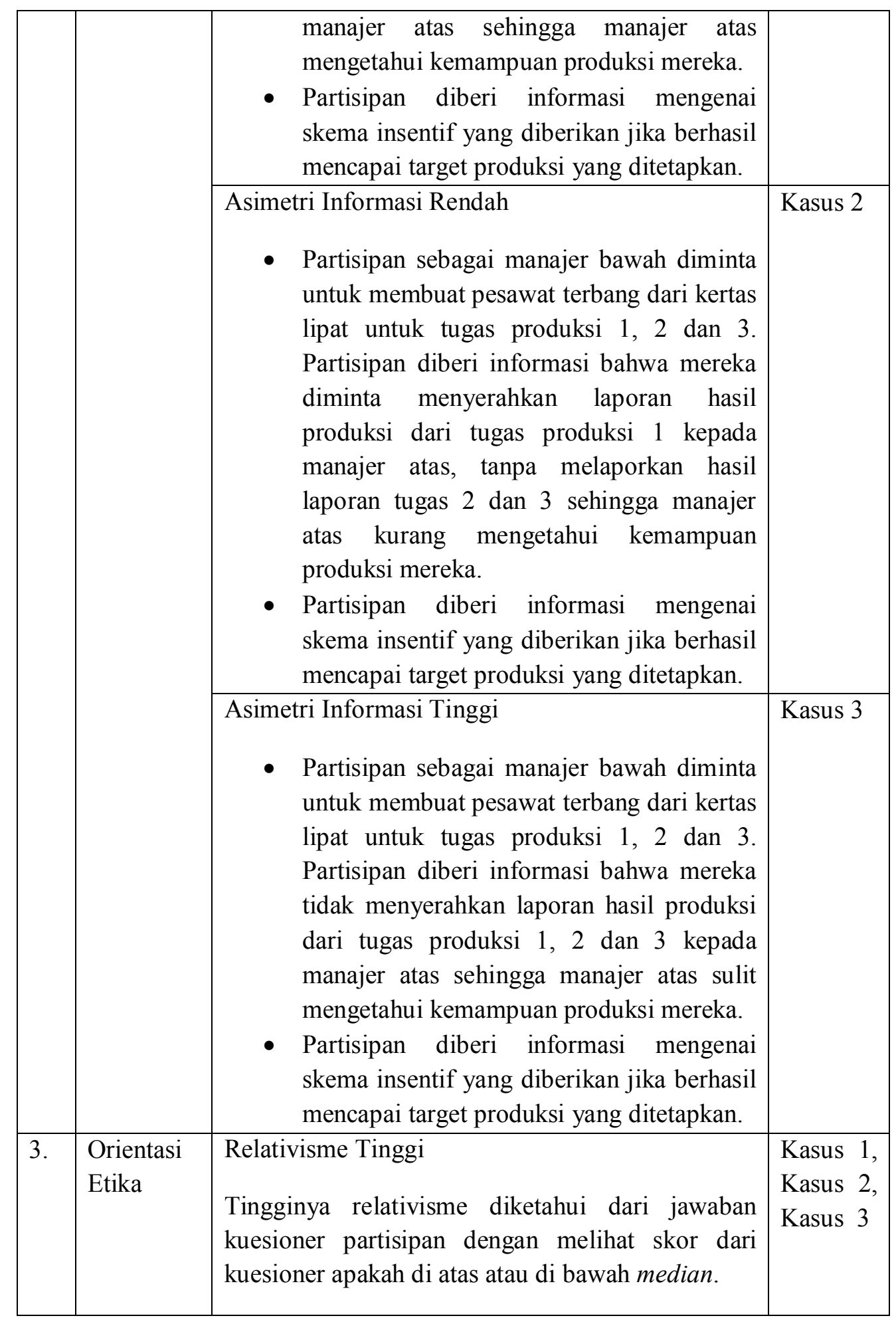




\begin{tabular}{|c|c|c|c|}
\hline & & $\begin{array}{l}\text { Relativisme Rendah } \\
\text { Tinggi rendahnya relativisme dinilai dari jawaban } \\
\text { dari kuesioner partisipan dengan melihat skor dari } \\
\text { kuesioner apakah di atas atau di bawah median. }\end{array}$ & $\begin{array}{ll}\text { Kasus } & 1, \\
\text { Kasus } & 2 \\
\text { Kasus } & 3\end{array}$ \\
\hline & & $\begin{array}{l}\text { Idealisme Tinggi } \\
\text { Tingginya idealisme diketahui dari jawaban } \\
\text { kuesioner partisipan dengan melihat skor dari } \\
\text { kuesioner apakah di atas atau di bawah median. }\end{array}$ & $\begin{array}{ll}\text { Kasus } & 1, \\
\text { Kasus } & 2, \\
\text { Kasus } & 3\end{array}$ \\
\hline & & $\begin{array}{l}\text { Idealisme Rendah } \\
\text { Rendahnya idealisme diketahui dari jawaban } \\
\text { kuesioner partisipan dengan melihat skor dari } \\
\text { kuesioner apakah di atas atau di bawah median. }\end{array}$ & $\begin{array}{ll}\text { Kasus } & 1, \\
\text { Kasus } & 2, \\
\text { Kasus } & 3\end{array}$ \\
\hline & & $\begin{array}{l}\text { Exceptionist } \\
\text { Partisipan termasuk tipe exceptionist ketika } \\
\text { memiliki relativisme dan idealisme rendah. }\end{array}$ & $\begin{array}{ll}\text { Kasus } & 1, \\
\text { Kasus } & 2, \\
\text { Kasus } & 3\end{array}$ \\
\hline & & $\begin{array}{l}\text { Absolutist } \\
\text { Partisipan termasuk tipe absolutist ketika memiliki } \\
\text { relativisme rendah dan idealisme tinggi. }\end{array}$ & $\begin{array}{ll}\text { Kasus } & 1, \\
\text { Kasus } & 2, \\
\text { Kasus } & 3\end{array}$ \\
\hline & & $\begin{array}{l}\text { Subjectivist } \\
\text { Partisipan termasuk tipe subjectivist ketika } \\
\text { memiliki relativisme tinggi dan idealisme rendah. }\end{array}$ & $\begin{array}{ll}\text { Kasus } & 1, \\
\text { Kasus } & 2, \\
\text { Kasus } & 3\end{array}$ \\
\hline & & $\begin{array}{l}\text { Situationist } \\
\text { Partisipan memiliki tipe situationist ketika } \\
\text { memiliki relativisme dan idealisme tinggi. }\end{array}$ & $\begin{array}{ll}\text { Kasus } & 1, \\
\text { Kasus } & 2, \\
\text { Kasus } & 3\end{array}$ \\
\hline
\end{tabular}

Sumber: Data primer diolah (2014)

\section{H. Teknik Analisis Data}

\section{Statistik Deskriptif}

Statistik deskriptif digunakan peneliti untuk memberikan informasi mengenai karakteristik variabel penelitian dan data demografi responden 
(Arfan, 2008). Ukuran yang digunakan dalam deskripsi antara lain berupa frekuensi, mean, median, dan deviasi standar.

\section{Manipulation Check}

Partisipan diminta mengisi manipulation check untuk mengetahui apakah partisipan memahami treatment yang diberikan setelah partisipan diminta untuk membaca treatment asimetri informasi. Partisipan yang lolos manipulation check maka data dari partisipan tersebut dapat diolah lebih lanjut, sedangkan partisipan yang tidak lolos manipulation check maka data dari partisipan tersebut tidak akan diolah. Hal tersebut karena partisipan yang tidak lolos manipulation check tidak membaca secara seksama dan tidak paham kasus perlakuan yang diberikan sehingga akan mempengaruhi respon partisipan tersebut.

Partisipan dinyatakan lolos manipulation check jika dapat menjawab delapan soal yang diberikan. Jika partisipan salah dalam menjawab manipulation check maka partisipan tersebut tidak lolos manipulation check. Partisipan harus menjawab semua soal dengan benar karena soal-soal tersebut berkaitan dengan kasus perlakuan asimetri informasi. Jika partisipan menjawab salah maka akan mempengaruhi respon partisipan tersebut.

Partisipan diminta memberi respon benar atau salah terkait pertanyaan yang diberikan oleh peneliti. Pertanyaan yang diberikan berkaitan dengan kasus yang diberikan peneliti pada angket penelitian. Partisipan yang mengisi jawaban salah pada manipulation check maka partisipan tersebut tidak paham 
mengenai treatment yang diberikan sehingga data dari pertisipan tersebut tidak akan diikutsertakan.

Pertanyaan manipulation check berkaitan tentang 1) tugas partisipan dimana partisipan diminta menentukan target produksi berdasarkan kemampuan kinerja, insentif, dan kondisi asimetri informasi; 2) insentif yang diberikan jika berhasil melampaui target produksi; 3) soal mengenai skema insentif; 4) laporan yang diserahkan kepada atasan; 5) kompensasi yang akan saya terima akan semakin besar jika selisih jumlah pesawat terbang yang dihasilkan dengan targer produksi yang diajukan semakin besar; 7) tingkat pengetahuan atasan mengenai kemampuan kinerja manajer bawah; dan 8) kesempatan yang dimiliki manajer bawah terkait kondisi asimetri informasi.

\section{Uji Kualitas Data}

\section{a. Pilot Test}

Pilot test digunakan untuk memastikan bahwa instrumen yang digunakan peneliti dapat dimengerti oleh partisipan sehingga dapat digunakan untuk memperoleh data yang sesuai. Pilot test akan dilakukan pada mahasiswa Akuntansi S1 kelas B angkatan 2010 Universitas Negeri Yogyakarta. Pilot test akan melibatkan 30 mahasiswa yang dibagi menjadi 3 kelompok tidak ada asimetri informasi, asimetri informasi rendah, dan asimetri informasi tinggi sehingga masing-masing kelompok perlakuan terdiri dari 10 mahasiswa. 


\section{b. Uji Validitas}

Uji validitas dilakukan untuk mengukur apakah alat ukur yang digunakan dapat mengukur apa yang seharusnya diukur sehingga diperoleh data-data yang valid (Anwar, 2013). Uji validitas dilakukan pada kuesioner orientasi etika dengan menggunakan uji Pearson Correlation dengan rumus:

$$
r=\frac{N\left(\sum X Y\right)-\left(\sum X \sum Y\right)}{\sqrt{\left[N \sum X^{2}-\left(\sum X\right)^{2}\right]\left[N \sum Y^{2}-\left(\sum Y\right)^{2}\right]}}
$$

dimana :

$$
\begin{array}{ll}
\mathrm{r} & =\text { koefisien korelasi } \\
\mathrm{X} & =\text { skor butir pertanyaan } \\
\mathrm{Y} & =\text { skor total butir pertanyaan } \\
\mathrm{N} & =\text { jumlah sampel (responden) }
\end{array}
$$

Nilai $r$ dibandingkan dengan nilai $r$ tabel dengan derajad bebas (n-2). Jika nilai $r$ hitung lebih besar daripada nilai $r$ tabel pada alfa tertentu maka item-item pertanyaan dalam kuesioner berkorelasi signifikan terhadap skor total sehingga dapat dinyatakan valid. Jika $r$ hitung lebih kecil dari $r$ tabel maka item-item pertanyaan dalam kuesioner tidak berkorelasi secara signifikan terhadap skor total sehingga item-item pertanyaan tersebut dinyatakan tidak valid (Anwar, 2013).

Selain pengujian validitas instrumen kuesioner, peneliti akan melakukan pengujian validitas instrumen treatment asimetri informasi. Pengujian validitas instrumen treatment dilakukan dengan face validity. 
Face validity adalah pengukuran validitas instrumen dengan cara melihat sepintas apakah instrumen yang digunakan sesuai dengan konsep variabel yang digunakan (Anwar, 2013). Face validity dilakukan dengan cara meminta beberapa orang untuk mengisi instrumen eksperimen dan meminta pendapat mereka untuk keperluan revisi.

\section{c. Uji Reabilitas}

Uji reabilitas dilakukan untuk mengetahui apakah kuesioner orientasi etika yang digunakan dapat dipercaya. Dikatakan dapat dipercaya apabila digunakan beberapa kali untuk mengukur objek yang sama maka akan menghasilkan hasil yang relatif sama. Uji reabilitas dilakukan dengan menggunakan uji Cronbach's Alpha.

$$
\mathrm{r}=\left[\frac{k}{k-1}\right]\left[1-\frac{\Sigma \sigma_{b}^{2}}{\sigma_{t}^{2}}\right]
$$

dimana :

$\mathrm{r} \quad=$ koefisien reabilitas Cronbach's Alpha

$\mathrm{k}$ = banyaknya pertanyaan

$\Sigma \sigma_{b}^{2}=$ total varians butir pertanyaan

$\sigma_{t}^{2}=$ total varians

Instrumen kuesioner dikatakan reliabel jika nilai Cronbach's Alpha lebih besar dari $\mathrm{r}$ tabel.Instrumen memiliki reabilitas yang tinggi jika nilai koefisien yang diperoleh $>0,60$ (Anwar, 2013). 


\section{Uji Asumsi ANOVA}

Penelitian akan menggunakan one way dan two-ways ANOVA untuk menguji hipotesis yang diajukan. Sebelum dilakukan pengujian hipotesis dengan ANOVA, akan dilakukan terlebih dahulu uji normalitas dan uji homogenitas sebagai syarat dilakukannya uji ANOVA, yaitu varians data harus homogen, data berdistribusi normal, dan pengambilan sampel dilakukan secara acak (Efferin, Darmadji, \& Tan, 2008).

\section{a. Uji Normalitas}

Uji normalitas digunakan untuk mengetahui apakah variabel independen dan variabel dependen berdistribusi normal atau tidak (Yusuf, 2000). Pengujian normalitas distribusi data populasi dilakukan dengan menggunakan uji Kolmogorov Smirnov. Jika nilai signifikansi ( $p$-value) > 0,05, maka data berdistribusi normal, jika nilai signifikansi ( $p$-value) < 0,05 maka data tidak berdistribusi normal.

\section{b. Uji Homogenitas Varians}

Uji homogenitas dilakukan untuk mengetahui apakah varians populasi sama atau tidak. Untuk menguji homogenitas dapat dilakukan uji Levene's Test. Jika nilai signifikansi $>0,05$ maka dapat disimpulkan bahwa varians kelompok data adalah homogen (Efferin, Darmadji \& Tan, 2008). 


\section{c. Random Sampling}

Untuk menguji signifikansi maka sampel untuk setiap kelompok perlakuan harus diambil secara acak (Imam, 2011). Hal ini agar setiap kelompok dapat diperbandingkan.

\section{Pengujian Hipotesis}

\section{a. ANOVA}

1) Pengujian Pengaruh Tingkatan Asimetri Informasi terhadap Senjangan Anggaran

Pengujian one way ANOVA dilakukan untuk mengetahui pengaruh satu faktor variabel yang digunakan, yaitu asimetri informasi terhadap senjangan anggaran. Model matematis untuk analisis one way ANOVA sebagai berikut:

$$
y_{i j}=\mu+\tau_{i}+\epsilon_{i j}
$$

dimana:

$i=$ perlakuan

$j$ = pengulangan

$y_{i j}=$ pengamatan ke-ij

$\mu=$ efek rata-rata umum

$\tau_{i}=$ efek perlakuan ke-i

$\epsilon_{i j}=$ komponen kekeliruan acak

Pengujian pengaruh asimetri informasi terhadap senjangan anggaran menggunakan ANOVA untuk model efek tetap (fixed effect model) dimana kelompok perlakuan untuk asimetri informasi sudah ditetapkan dan tidak diambil secara acak, yaitu kelompok 
tidak ada asimetri informasi, asimetri informasi rendah, dan asimetri informasi tinggi untuk perlakuan faktor asimetri informasi.

Eksperimen yang dilakukan merupakan rancangan acak lengkap dimana pemberian perlakuan pada sampel dilakukan secara acak. Rancangan eksperimen yang digunakan akan mempengaruhi analisis ANOVA yang akan dilakukan. Pengujian dengan menggunakan ANOVA dilakukan dengan cara menguraikan jumlah kuadrat total respon ke dalam komponen-komponennya, yaitu jumlah kuadrat antar kelompok perlakuan (between subject) dan jumlah kuadrat dalam kelompok (within subject). Jumlah kuadrat dalam kelompok berarti kelompok error. Data eksperimen yang didapat akan disusun seperti di bawah ini.

Tabel 6. Skema Data Eksperimen Berdasarkan Tingkatan Asimetri Informasi

\begin{tabular}{|c|c|c|c|c|}
\hline & \multicolumn{3}{|c|}{ Perlakuan } & \multirow[b]{2}{*}{ Jumlah } \\
\hline & $\begin{array}{c}\text { Tidak Ada } \\
\text { Asimetri } \\
\text { Informasi } \\
\text { (1) }\end{array}$ & $\begin{array}{l}\text { Asimetri } \\
\text { Informasi } \\
\text { Rendah } \\
(2)\end{array}$ & $\begin{array}{c}\text { Asimetri } \\
\text { Informasi } \\
\text { Tinggi } \\
\text { (3) }\end{array}$ & \\
\hline \multirow[t]{4}{*}{ Pengulangan } & y11 & y21 & y31 & \\
\hline & y12 & y22 & $y 23$ & \\
\hline & y13 & y23 & $\mathrm{y} 33$ & \\
\hline & yln & $y 2 n$ & $\mathrm{y} 3 \mathrm{n}$ & \\
\hline Jumlah & $\mathrm{yl}$ & y2 & $\mathrm{y} 3$ & $y=\sum J_{i}$ \\
\hline Sampel & $\mathrm{n} 1$ & $\mathrm{n} 2$ & n3 & $y=\sum n_{1}$ \\
\hline Rata-Rata & $\overline{y 1}$ & $\overline{y 2}$ & $\overline{y 3}$ & $\bar{y}$ \\
\hline
\end{tabular}

Sumber: Data primer diolah (2014)

Keterangan:

y1 = jumlah nilai senjangan anggaran pada tingkatan tidak ada asimetri informasi 


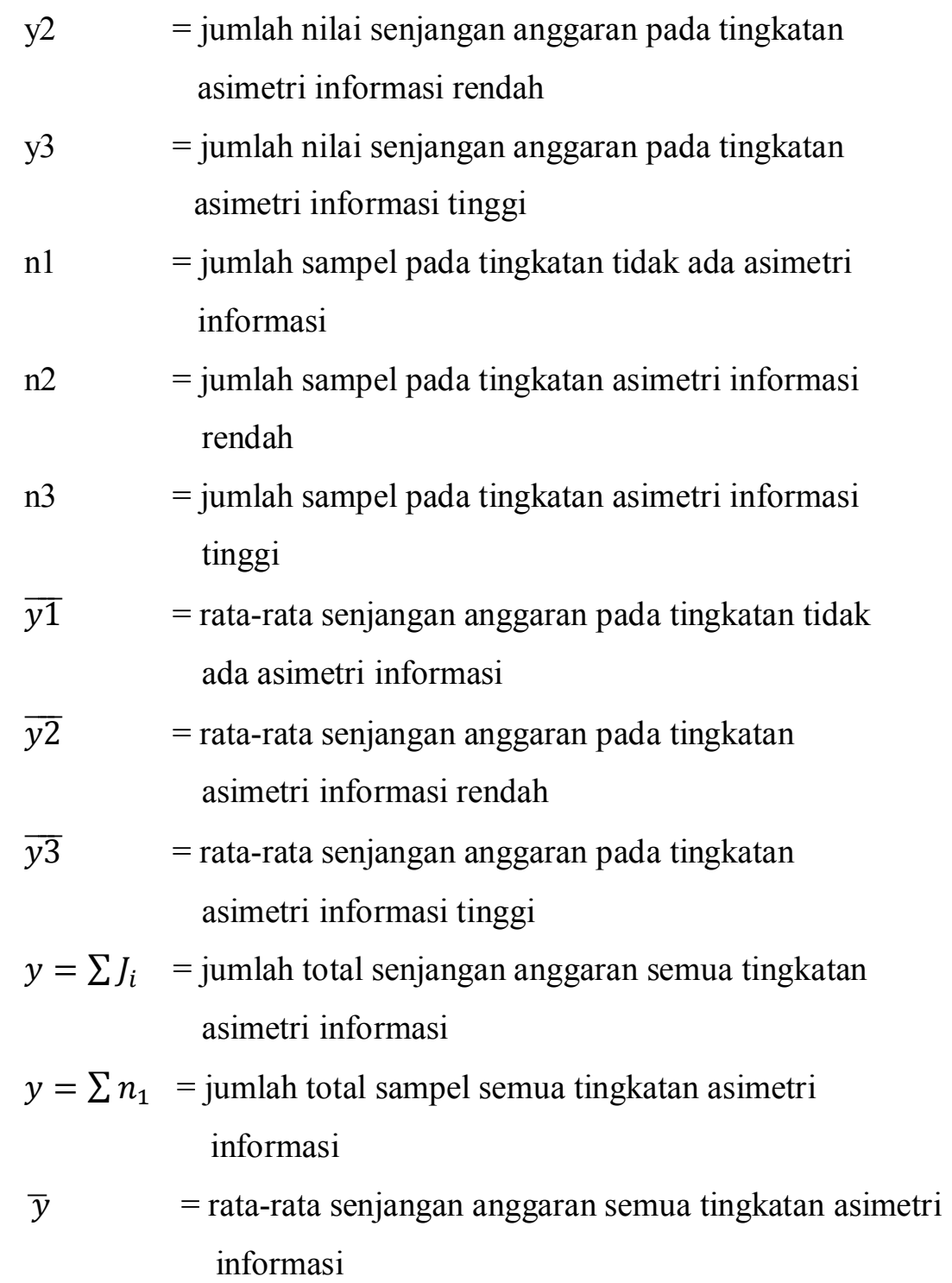

Rumus ANOVA untuk fixed effect model dan eksperimen acak lengkap sebagai berikut:

$$
\begin{aligned}
& \text { Jumlah Kuadrat Rata-Rata } \rightarrow J K R=\frac{J^{2}}{N} \\
& \text { Jumlah Kuadrat Total Terkoreksi } \rightarrow J K T=\sum \sum_{i=i}^{k} \sum_{j=1}^{n} Y_{i j}^{2}-J K R \\
& \text { Jumlah Kuadrat Perlakuan } \rightarrow J K P=\frac{1}{n} \sum J_{i}^{2}-J K R
\end{aligned}
$$


Jumlah Kuadrat Error $\quad \rightarrow J K E=J K T-J K P$

Penghitungan ANOVA di atas untuk jumlah pengulangan yang sama pada tiap-tiap tingkatan asimetri informasi. Jika jumlah pengulangan untuk tiap-tiap kelompok tingkatan asimetri informasi berbeda maka digunakan penghitungan di bawah ini.

$$
\begin{array}{ll}
\text { Jumlah Kuadrat Rata-Rata } \rightarrow J K R & =\frac{J^{2}}{N} \\
\text { Junlah Kuadrat Total Terkoreksi } \rightarrow J K T & =\sum y^{2}=\sum_{i=1}^{k} \sum_{j=1}^{n_{i}} y_{i j}^{2} \\
\text { Jumlah Kuadrat Perlakuan } & \rightarrow J K P=\sum_{i=1}^{k} \frac{J_{i}^{2}}{n_{i}}-\frac{J^{2}}{N} \\
\text { Jumlah Kuadrat Erorr } & \rightarrow J K E=J K T-J K P
\end{array}
$$

Keterangan:

$$
\begin{aligned}
J^{2}= & \text { jumlah kuadrat data semua tingkatan asimetri } \\
& \text { informasi } \\
= & \text { total sampel semua tingkatan asimetri informasi } \\
\mathrm{N} \quad & \text { kuadrat senjangan anggaran pada semua tingkatan } \\
\sum \sum_{i=i}^{k} \sum_{j=1}^{n} Y_{i j}^{2}= & \text { asimetri informasi } \\
= & \text { jumlah sampel pada tiap tingkatan asimetri } \\
& \text { informasi }
\end{aligned}
$$

Penghitungan di atas digunakan untuk menghitung Fhitung karena dalam ANOVA pengujian dilakukan dengan membandingkan Fhitung dengan Ftabel. Uji F pada ANOVA digunakan untuk mengetahui faktor perlakuan terhadap keragaman data hasil percobaan. Hasil perhitungan di atas disajikan pada tabel ANOVA di bawah ini. 
Tabel 7. ANOVA untuk Klasifikasi Satu Arah Fixed Effect Model

\begin{tabular}{|c|c|c|c|c|}
\hline $\begin{array}{l}\text { Sumber } \\
\text { Variasi }\end{array}$ & df & $\begin{array}{c}\text { Jumlah } \\
\text { Kuadrat }\end{array}$ & Kuadrat Tengah & Fhitung \\
\hline $\begin{array}{l}\text { Di antara } \\
\text { Perlakuan } \\
\text { (Between } \\
\text { Subject) }\end{array}$ & $\mathrm{k}-1$ & JKA & $\mathrm{KTA}=\frac{J K A}{(k-1)}$ & \\
\hline $\begin{array}{l}\text { Dalam } \\
\text { Perlakuan } \\
\text { (Within } \\
\text { Subject) }\end{array}$ & $\mathrm{N}-\mathrm{k}$ & JKE & $\mathrm{KTE}=\frac{J K E}{N-k}$ & $\frac{\text { KTA }}{\text { KTE }}$ \\
\hline $\begin{array}{l}\text { Total } \\
\text { Terkoreksi }\end{array}$ & $\mathrm{N}-1$ & JKT & & \\
\hline
\end{tabular}

Sumber: Data primer diolah (2014)

Keterangan:

df $\quad=$ derajad kebebasan

JKA = jumlah kuadrat asimetri informasi

JKE $=$ jumlah kuadrat asimetri error

KTA = kuadrat tengah asimetri informasi

KTE = kuadrat tengah error

$\mathrm{K}=$ jumlah tingkatan asimetri informasi

$\mathrm{N} \quad=$ jumlah total pengulangan

Fhitung kemudian akan dibandingkan dengan Ftabel untuk menolak atau menerima hipotesis. Taraf signifikansi $\alpha$ akan diperoleh Ftabel, yaitu $\mathrm{F} \alpha,(\mathrm{k}-1 ; \mathrm{N}-1)$. Kriteria pengujian jika nilai Fhitung $\geq \mathrm{F} \alpha,(\mathrm{k}-1 ; \mathrm{N}-1)$ maka terdapat perbedaan antara kelompok tingkatan asimetri informasi, sedangkan jika Fhitung $\leq \mathrm{F} \alpha,(\mathrm{k}-1$; N1) maka rata-rata nilai senjangan anggaran pada tingkatan asimetri informasi adalah sama. 


\section{2) Pengaruh Orientasi Etika terhadap Hubungan Asimetri Informasi dan Senjangan Anggaran}

Uji ANOVA bisa dilakukan pada variabel-variabel independen yang termasuk kategori nominal dan variabel dependen yang termasuk kategori interval. Pengujian two way ANOVA dilakukan untuk mengetahui pengaruh dua faktor variabel yang digunakan, yaitu asimetri informasi dan orientasi etika terhadap senjangan anggaran. Pengujian pengaruh orientasi etika terhadap hubungan asimetri informasi dan senjangan anggaran menggunakan ANOVA untuk model efek tetap (fixed effect model) dimana kelompok perlakuan untuk asimetri informasi dan orientasi etika sudah ditetapkan dan tidak diambil secara acak.

Kelompok asimetri informasi terdiri dari kelompok tidak ada asimetri informasi, asimetri informasi rendah, dan asimetri informasi tinggi. Kelompok orientasi etika terdiri dari relativisme dan idealisme yang akan dibagi berdasarkan tinggi rendahnya relativisme dan idealisme. Kelompok relativisme terdiri kelompok relativisme rendah dan relativisme tinggi. Kelompok idealisme terdiri dari idealisme rendah dan idealisme tinggi. Kelompok klasifikasi orientasi etika terdiri dari exceptionist, situationist, absolutist, dan subjectivist.

Eksperimen yang dilakukan merupakan rancangan acak lengkap dimana pemberian perlakuan pada sampel dilakukan secara 
acak. Eksperimen juga menggunakan desain faktorial mengingat ada dua faktor yang digunakan untuk menilai senjangan anggaran yang dibuat manajer bawah. Desain faktorial harus mewakili jumlah kelompok komponen untuk tiap-tiap faktor yang digunakan. Peneliti menggunakan tiga kelompok tingkatan untuk asimetri informasi, yaitu tidak ada asimetri informasi, asimetri informasi rendah, dan asimetri informasi tinggi.

Peneliti juga menggunakan dua kelompok tingkatan relativisme rendah dan tinggi. Berdasarkan hal tersebut maka desain faktorial yang digunakan adalah $3 \times 2$. Peneliti juga membuat desain faktorial untuk pengaruh faktor asimetri informasi dan idealisme terhadap senjangan anggaran. Kelompok asimetri informasi terdiri dari tiga tingkatan, sedangkan kelompok idealisme terdiri dari dua tingkatan, yaitu idealisme rendah dan idealisme tinggi. Berdasarkan tingkatan masing-masing faktor sehingga desain faktorial berbentuk $3 \times 2$.

Selain itu, peneliti membuat desain faktorial untuk asimetri informasi dan orientasi etika. Kelompok asimetri informasi terdiri dari tiga tingkatan, sedangkan orientasi etika terdiri dari empat kelompok, yaitu exceptionist, situationist, absolutist, dan subjectivist. Berdasarkan tingkatan masing-masing faktor maka desain faktorialnya berbentuk $3 \mathrm{X} 4$. Asimetri informasi dan orientasi 
etikaakan diuji pengaruhnya terhadap senjangan anggaran kemudian diinteraksikan untuk mengetahui efek interaksinya.

Rancangan eksperimen yang digunakan akan mempengaruhi analisis ANOVA yang akan dilakukan. Pengujian dengan menggunakan ANOVA dilakukan dengan cara menguraikan jumlah kuadrat total respon ke dalam komponen-komponennya, yaitu jumlah kuadrat antar kelompok perlakuan (between subject) dan jumlah kuadrat dalam kelompok (within subject). Jumlah kuadrat dalam kelompok berarti kelompok error. Model matematis untuk analisis two ways ANOVA dengan desain faktorial dalam suatu desain acak lengkap sebagai berikut:

$$
y_{i j k}=\mu+\tau_{i}+\beta j+(\tau \beta) i j+\epsilon_{i j k}
$$

dimana:

$$
\begin{aligned}
& i \quad=\text { perlakuan faktor asimetri informasi } \\
& j \quad=\text { perlakuan faktor orientasi etika } \\
& k \quad=\text { pengulangan } \\
& y_{i j k}=\text { nilai respon untuk tingkatan asimetri informasi dan } \\
& \text { orientasi etika pada ulangan ke-k } \\
& \mu \quad=\text { efek rata-rata umum } \\
& \tau_{i} \quad=\text { efek rata-rata tingkatan asimetri informasi } \\
& \beta j \quad=\text { efek rata-rata tingkatan orientasi etika } \\
& (\tau \beta) i j=\text { efek rata-rata interaksi tingkatan asimetri informasi dan } \\
& \text { tingkatan orientasi etika } \\
& \epsilon_{i j k} \quad=\text { efek kekeliruan acak }
\end{aligned}
$$


Rumus ANOVA untuk fixed effect model dan eksperimen acak lengkap sebagai berikut:

Jumlah Kuadrat Terkoreksi, $J K_{T}=\sum_{i=1}^{a} \sum_{j=1}^{b} \sum_{k=i}^{n} y_{i j k}^{2}-\frac{y^{2}}{a b n}$

Jumlah Kuadrat Faktor Asimetri Informasi, $J K_{A}=\frac{1}{n i} \sum_{i=1}^{a} y_{i}^{2}-\frac{y^{2}}{a b n}$

Jumlah Kuadrat Faktor Orientasi Etika, $J K_{O E}=\frac{1}{n j} \sum_{j=1}^{a} y_{j}^{2}-\frac{y^{2}}{a b n}$

Jumlah Kuadrat Interaksi, $J K_{A O E}=J K_{\text {subtotal }}-J K_{A}-J K_{O E}$

dimana $K_{\text {subtotal }}=\frac{1}{n} \sum_{i=1}^{a} \sum_{j=1}^{b} y_{i j}^{2}-\frac{y^{2}}{a b n}$

Jumlah Kuadrat Kekeliruan, $J K_{E}=J K_{T}-J K_{A}-J K_{O E}-J K_{A O E}$

Keterangan:

$\sum_{i=1}^{a} \sum_{j=1}^{b} \sum_{k=i}^{n} y_{i j k}^{2}=$ jumlah total kuadrat senjangan anggaran berdasarkan asimetri informasi dan orientasi etika

$y^{2} \quad=$ jumlah total senjangan anggaran yang dikuadratkan

$\sum_{i=1}^{a} y_{i}^{2} \quad=$ jumlah total senjangan anggaran berdasarkan orientasi etika yang dikuadratkan

ni $\quad=$ jumlah sampel tiap kelompok orientasi etika

abn $\quad=$ jumlah total sampel

$\sum_{j=1}^{a} y_{j}^{2} \quad=$ jumlah total senjangan anggaran berdasarkan asimetri informasi yang dikuadratkan

nj $\quad=$ jumlah sampel tiap kelompok orientasi etika 
Hasil perhitungan di atas kemudian disajikan seperti tabel di bawah ini.

Tabel 8. ANOVA untuk Klasifikasi Dua Arah dengan Desain Faktorial dan Fixed Effect Model

\begin{tabular}{|c|c|c|c|c|}
\hline $\begin{array}{l}\text { Sumber } \\
\text { Variasi }\end{array}$ & $\mathrm{df}$ & $\begin{array}{l}\text { Jumlah } \\
\text { Kuadrat }\end{array}$ & Kuadrat Tengah & Fhitung \\
\hline $\begin{array}{l}\text { Faktor } \\
\text { Asimetri } \\
\text { Informasi }\end{array}$ & $a-1$ & JKA & $\mathrm{KTA}=\frac{J K A}{(a-1)}$ & $\frac{\text { KTA }}{\text { KTE }}$ \\
\hline $\begin{array}{l}\text { Faktor } \\
\text { Orientasi } \\
\text { Etika }\end{array}$ & $\mathrm{b}-\mathrm{k}$ & JKOE & $\mathrm{KTOE}=\frac{J K O E}{(b-1)}$ & $\frac{\text { KTOE }}{\text { KTE }}$ \\
\hline $\begin{array}{l}\text { Interaksi } \\
\text { Asimetri } \\
\text { Informasi } \\
\text { dan } \\
\text { Orientasi } \\
\text { Etika }\end{array}$ & $(a-1)(b-1)$ & JKAOE & $\mathrm{KTAOE}=\frac{J K A O E}{(a-1)(b-1)}$ & $\frac{\text { KTAOE }}{\text { KTE }}$ \\
\hline Kekeliruan & $a b(n-1)$ & JKE & $\mathrm{KTE}=\frac{J K E}{a b(n-1)}$ & \\
\hline Total & abn-1 & JKT & & \\
\hline
\end{tabular}

Sumber: Data primer diolah (2014)

Keterangan:

df $\quad=$ derajad kebebasan

JKA $=$ jumlah kuadrat asimetri informasi

JKE $=$ jumlah kuadrat asimetri error

KTA $=$ kuadrat tengah asimetri informasi

KTE = kuadrat tengah error

$\mathrm{k}=$ jumlah tingkatan asimetri informasi

$\mathrm{N} \quad=$ jumlah total pengulangan

Fhitung kemudian akan dibandingkan dengan Ftabel untuk mengetahui apakah terdapat perbedaan rata-rata nilai senjangan anggaran pada tiap-tiap kelompok asimetri informasi berdasarkan 
orientasi etika. Di bawah ini merupakan rumus untuk membandingkan Ftabel.

Ftabel asimetri informasi (a-1; ab(n-1))

Ftabel orientasi etika (b-1; ab(n-1))

Ftabel interaksi (a-1)(b-1); ab(n-1))

Masing-masing Fhitung asimetri informasi, orientasi etika, dan interaksinya dibandingkan dengan Ftabel. Jika Fhitung $\geq$ Ftabel maka terdapat perbedaan rata-rata nilai senjangan anggaran pada tiap kelompok asimetri informasi dan orientasi etika, sedangkan jika Fhitung $\leq$ Ftabel maka rata-rata nilai senjangan anggaran pada tiap kelompok asimetri informasi dan orientasi etika adalah sama (Suwanda, 2011).

Kriteria pengujian ANOVA untuk mengetahui diterima atau ditolaknya hipotesis juga bisa dengan menggunakan $p$-value. Jika $p$ value $<0,05$ maka dinyatakan signifikan dan hipotesis diterima, sedangkan jika $p$-value $>0,05$ maka dinyatakan tidak signifikan dan hipotesis ditolak (Imam, 2011).

\section{b. Uji Post Hoc}

Jika hasil dari ANOVA menunjukkan hasil yang menunjukkan adanya perbedaan yang signifikan maka diperlukan uji perbandingan ganda atau Post Hoc. Uji Post Hoc dilakukan untuk menentukan rata-rata kelompok mana yang berbeda secara signifikan dari rata-rata kelompok yang lain. Uji Post Hoc 
dilakukan pada kelompok tingkatan asimetri informasi untuk mengetahui kelompok asimetri informasi mana yang memiliki perbedaan rata-rata nilai senjangan anggaran yang signifikan. Uji Post Hoc juga dilakukan pada kelompok klasifikasi orientasi etika untuk mengetahui tipe orientasi etika apa yang memiliki perbedaan rata-rata nilai senjangan anggaran yang signifikan. Uji Post Hoc dilakukan dengan uji Scheffe.

Uji Scheffe merupakan uji perbandingan ganda yang paling sering digunakan dan konservatif. Uji Scheffe dilakukan ketika perbandingan antara kelompok tingkatan asimetri informasi dan orientasi etika dilakukan setelah dilakukan uji ANOVA. Uji Scheffe dilakukan dengan menghitung nilai F Scheffe dengan rumus:

$$
F s=\frac{(\overline{x a}-\overline{x b})}{\sqrt{\left(\frac{M S w a}{n a}+\frac{M S w b}{n b}\right)}}
$$

dimana:

$$
\begin{array}{ll}
\mathrm{Fs} & =\text { nilai harga } \mathrm{F} \text { Scheffe } \\
\bar{x} & =\text { rata-rata kelompok } \\
\mathrm{MSw} & =\text { mean square within } \\
\mathrm{N} & =\text { jumlah sampel tiap kelompok }
\end{array}
$$

Tingkatan asimetri informasi dan orientasi etika akan dibandingkan satu sama lain untuk melihat perbedaan mana yang paling signifikan. Rata-rata senjangan anggaran pada tingkatan tidak ada asimetri informasi akan dibandingkan dengan rata-rata 
senjangan anggaran pada tingkatan asimetri rendah, rata-rata senjangan anggaran pada tingkatan tidak ada asimetri informasi akan dibandingkan dengan rata-rata senjangan anggaran pada tingkatan asimetri informasi tinggi, dan rata-rata senjangan anggaran pada tingkatan asimetri informasi rendah akan dibandingkan dengan rata-rata senjangan anggaran pada asimetri informasi tinggi.

Perbandingan rata-rata senjangan anggaran pada tingkatan asimetri informasi juga akan dilakukan berdasarkan tingkatan orientasi etika. Rata-rata senjangan anggaran pada relativisme tinggi akan dibandingkan dengan relativisme rendah. Rata-rata senjangan anggaran pada idealisme tinggi akan dibandingkan dengan idealisme rendah. Rata-rata senjangan anggaran pada exceptionistakan dibandingkan dengan absolutist, subjectivist, dan situationist, rata-rata senjangan anggaran pada absolutist akan dibandingkan dengan subjectivist dan situationist, rata-rata senjangan anggaran pada subjectivist akan dibandingkan dengan situationist.

Selanjutnya dicari Ftabel Scheffe dengan cara:

$$
\text { Ftabel }=\sqrt{(k-1) F_{(1-\alpha) ;(k-1)(N-k)}}
$$

$\mathrm{k}=$ jumlah tingkatan faktor

$\mathrm{N} \quad=$ jumlah sampel 
F Scheffe dibandingkan dengan Ftabel Scheffe untuk menentukan perbandingan mana yang signifikan. Jika F Scheffe > Ftabel Scheffe maka perbandingannya antar kelompok signifikan, sedangkan jika F Scheffe < Ftabel Scheffe maka tidak signifikan. Perbandingan kelompok yang memiliki nilai F Scheffe tinggi maka kelompok itulah yang memiliki perbedaan rata-rata nilai senjangan anggaran yang besar.

Uji Scheffe juga bisa dilihat dari selisih rata-rata antar kelompok perlakuan. Apabila menunjukkan signifikansi $<0,05$ maka dinyatakan signifikan, sedangkan jika selisih rata-rata kelompok perlakuan menunjukkan signifikansi $>0,05$ maka dinyatakan tidak signifikan (Hamid, 2011).

\section{c. Koefisien Determinasi}

Koefisien determinasi digunakan untuk menjelaskan proporsi atau persentase variasi dalam variabel dependen yang dijelaskan oleh variabel independen secara bersama-sama. Koefisien determinasi $\left(\mathrm{R}^{2}\right)$ digunakan untuk mengetahui seberapa besar persentase pengaruh variabel asimetri informasi dan orientasi etika terhadap senjangan anggaran. Nilai koefisien determinasi adalah antara nol dan satu.

Nilai koefisien determinasi $\left(\mathrm{R}^{2}\right)$ dilihat dari nilai Adjusted $R^{2}$ (Anwar, 2013). Nilai koefisien determinasi $\left(\mathrm{R}^{2}\right)$ yang kecil berarti kemampuan variabel-variabel independen dalam 
menjelaskan variasi variabel dependen sangat terbatas. Sebaliknya, nilai koefisien determinasi $\left(\mathrm{R}^{2}\right)$ yang mendekati satu berarti variabel-variabel independen memberikan hampir semua informasi yang dibutuhkan untuk memprediksi variasi variabel dependen (Arfan, 2008).

Koefisien determinasi diketahui dengan rumus:

$$
\begin{aligned}
R^{2} & =\frac{\text { Jumlah Kuadrat Model }}{\text { Jumlah Kuadrat Total }} \\
& =\frac{\text { JK Asimetri Informasi }+ \text { JK Orientasi Etika }+ \text { JK Interaksi }}{\text { JK Total }}
\end{aligned}
$$

dimana:

$\mathrm{R}^{2} \quad=$ koefisien determinasi

JK $=$ jumlah kuadrat 


\section{BAB IV}

\section{HASIL PENELITIAN DAN PEMBAHASAN}

\section{A. Deskripsi Data Penelitian}

Penelitian dilakukan dengan metode eksperimen yang melibatkan mahasiswa yang berperan sebagai manajer bawah. Mahasiswa yang terlibat adalah mahasiswa Akuntansi 2010 dan 2011 serta mahasiswa Pendidikan Akuntansi 2011 Universitas Negeri Yogyakarta sebanyak 175 orang. Sejumlah 141 orang memenuhi syarat lolos uji manipulation check untuk mengetahui pemahaman partisipan mengenai treatment, yang terdiri dari 46 partisipan untuk kelompok tidak ada asimetri informasi, 47 partisipan untuk kelompok asimetri informasi rendah, dan 48 partisipan untuk kelompok asimetri informasi tinggi.

Tabel 9. Deskripsi Data Penelitian

\begin{tabular}{|c|c|c|c|c|c|c|}
\hline \multirow[b]{2}{*}{ Subjek } & \multirow[b]{2}{*}{ Tahun } & \multirow[b]{2}{*}{ Kelas } & \multicolumn{3}{|c|}{ Jenis Kasus } & \multirow[b]{2}{*}{ Jumlah } \\
\hline & & & $\begin{array}{c}\text { Kasus } \\
\text { Tidak Ada } \\
\text { Asimetri } \\
\text { Informasi }\end{array}$ & $\begin{array}{c}\text { Kasus } \\
\text { Asimetri } \\
\text { Informasi } \\
\text { Rendah }\end{array}$ & $\begin{array}{c}\text { Kasus } \\
\text { Asimetri } \\
\text { Informasi } \\
\text { Tinggi }\end{array}$ & \\
\hline \multirow{2}{*}{ Pend. Akt } & \multirow{2}{*}{2011} & A & 12 & 13 & 13 & 38 \\
\hline & & B & 15 & 17 & 17 & 49 \\
\hline \multirow{2}{*}{ Akuntansi } & \multirow{2}{*}{2011} & A & 11 & 12 & 12 & 35 \\
\hline & & $\mathrm{B}$ & 9 & 10 & 9 & 28 \\
\hline & 2010 & A & 8 & 9 & 8 & 25 \\
\hline \multicolumn{3}{|c|}{ Jumlah } & 55 & 61 & 59 & 175 \\
\hline \multicolumn{3}{|c|}{$\begin{array}{l}\text { Tidak Lolos Manipulation } \\
\text { Check }\end{array}$} & 9 & 14 & 11 & 34 \\
\hline \multicolumn{3}{|c|}{ Data Subjek yang Dapat Diolah } & 46 & 47 & 48 & 141 \\
\hline
\end{tabular}

Sumber: Data primer diolah (2014) 
Tabel 10. Statistik Deskriptif Data

\begin{tabular}{|l|r|r|r|r|r|}
\hline & $\mathrm{N}$ & Minimum & Maximum & \multicolumn{1}{c|}{ Mean } & $\begin{array}{c}\text { Std. } \\
\text { Deviation }\end{array}$ \\
\hline Asimetri Informasi & 141 & 0 & 2 & 1.01 & .819 \\
\hline Relativisme & 141 & 0 & 1 & .50 & .502 \\
\hline Idealisme & 141 & 0 & 1 & .54 & .500 \\
\hline Produksi 1 & 141 & 2 & 10 & 4.63 & 1.798 \\
\hline Produksi 2 & 141 & 2 & 10 & 5.64 & 1.913 \\
\hline Produksi 3 & 141 & 3 & 12 & 6.81 & 2.308 \\
\hline $\begin{array}{l}\text { Expected } \\
\text { Performance }\end{array}$ & 141 & 2 & 10 & 5.13 & 1.809 \\
\hline Target & 141 & 1 & 11 & 4.78 & 2.188 \\
\hline Kompensasi & 141 & 10000 & 10700 & 10202.84 & 151.631 \\
\hline $\begin{array}{l}\text { Senjangan } \\
\text { Anggaran }\end{array}$ & 141 & .00 & 1.00 & .4109 & .28519 \\
\hline Valid N (listwise) & 46 & & & & \\
\hline
\end{tabular}

Sumber: Data primer diolah (2014)

Tabel 10 menunjukkan nilai minimum, nilai maksimum, mean, dan standar deviasi data yang didapat pada penelitian eksperimen. Dapat dilihat bahwa partisipan rata-rata dapat menghasilkan 4,63 pesawat terbang kertas pada tugas produksi 1 , sebanyak 5,64 pesawat terbang kertas pada tugas produksi 2 , dan 6,81 pesawat terbang kertas pada tugas produksi 3. Rata-rata kompensasi yang didapat partisipan adalah 10.202 .

Karakterisitik demografi responden pada penelitian ini terdiri dari enam bagian utama yaitu umur, jenis kelamin, tahun angkatan dan Indeks Prestasi Kumulatif (IPK), mata kuliah yang sudah lulus, dan program studi. Sebanyak 141 partisipan yang berhasil dilibatkan dalam penelitian ini. Data statistik demografis dapat dilihat di bawah ini. 


\section{Statistik Deskriptif Umur}

Tabel 11. Statistik Deskriptif Umur

\begin{tabular}{|c|c|c|c|c|}
\hline & $\begin{array}{c}\text { Umur } \\
\text { Kelompok } \\
\text { Tidak Ada } \\
\text { Asimetri } \\
\text { Informasi }\end{array}$ & $\begin{array}{c}\text { Umur } \\
\text { Kelompok } \\
\text { Asimetri } \\
\text { Informasi } \\
\text { Rendah }\end{array}$ & $\begin{array}{c}\text { Umur } \\
\text { Kelompok } \\
\text { Asimetri } \\
\text { Informasi } \\
\text { Tinggi }\end{array}$ & Total \\
\hline Valid & - & 1 & 1 & 2 \\
\hline 19 & 19 & 18 & 18 & 55 \\
\hline 20 & 21 & 24 & 23 & 68 \\
\hline 21 & 6 & 2 & 5 & 13 \\
\hline 22 & - & 2 & 1 & 3 \\
\hline Total & 46 & 47 & 48 & 141 \\
\hline
\end{tabular}

Sumber: Data primer diolah (2014)

Pada tabel 11 di atas terlihat bahwa total partisipan yang mengikuti ekperimen berumur 19 tahun sebanyak 2 orang, partisipan yang berumur 20 tahun sebanyak 55 orang, partisipan yang berumur 21 tahun sebanyak 68 orang, partisipan yang berumur 22 tahun sebanyak 13 orang, dan partisipan yang berumur lebih dari 22 tahun sebanyak 3 orang. Partisipan yang paling banyak mengikuti ekperimen adalah partisipan yang berumur 21 tahun.

\section{Statistik Deskripsi Gender}

Tabel 12. Statistik Deskriptif Gender

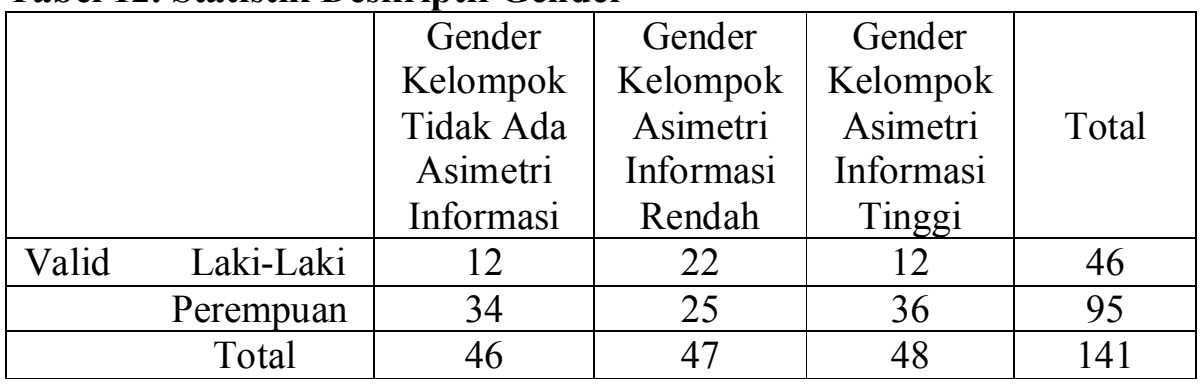

Sumber: Data primer diolah (2014)

Tabel 12 di atas menunjukkan bahwa total partisipan berjenis kelamin laki-laki yang mengikuti eksperimen adalah 46 orang, sedangkan 
partisipan perempuan sebanyak 95 orang. Partisipan berjenis kelamin perempuan adalah partisipan yang paling banyak.

\section{Statistik Deskriptif Angkatan}

Tabel 13. Statistik Deskriptif Angkatan

\begin{tabular}{|c|c|c|c|c|c|}
\hline & & $\begin{array}{c}\text { Angkatan } \\
\text { Kelompok } \\
\text { Tidak Ada } \\
\text { Asimetri } \\
\text { Informasi }\end{array}$ & $\begin{array}{c}\text { Angkatan } \\
\text { Kelompok } \\
\text { Asimetri } \\
\text { Informasi } \\
\text { Rendah }\end{array}$ & $\begin{array}{c}\text { Angkatan } \\
\text { Kelompok } \\
\text { Asimetri } \\
\text { Informasi } \\
\text { Tinggi } \\
\end{array}$ & Total \\
\hline Valid & 2010 & 8 & 7 & 7 & 22 \\
\hline & 2011 & 38 & 40 & 41 & 119 \\
\hline & Total & 46 & 47 & 48 & 141 \\
\hline
\end{tabular}

Sumber: Data primer diolah (2014)

Pada tabel 13 di atas menunjukkan bahwa ada dua angkatan yang mengikuti ekperimen, yaitu angkatan 2010 dan 2011. Angkatan 2011 adalah angkatan yang paling banyak mengikuti eksperimen, yaitu sebanyak 119 orang, sedangkan angkatan 2010 sebanyak 22 orang.

\section{Statistik Deskriptif IPK}

Tabel 14. Statistik Deskriptif IPK

\begin{tabular}{|c|c|c|c|c|}
\hline & $\begin{array}{c}\text { IPK } \\
\text { Kelompok } \\
\text { Tidak Ada } \\
\text { Asimetri } \\
\text { Informasi }\end{array}$ & $\begin{array}{c}\text { IPK } \\
\text { Kelompok } \\
\text { Asimetri } \\
\text { Informasi } \\
\text { Rendah }\end{array}$ & $\begin{array}{c}\text { IPK } \\
\text { Kelompok } \\
\text { Asimetri } \\
\text { Informasi } \\
\text { Tinggi }\end{array}$ & Total \\
\hline Valid $<3,00$ & & & 2 & 2 \\
\hline $3,00-3,25$ & 8 & 17 & 6 & 31 \\
\hline $3,26-3,50$ & 14 & 19 & 23 & 56 \\
\hline$>3,51$ & 24 & 11 & 17 & 52 \\
\hline Total & 46 & 47 & 48 & 141 \\
\hline
\end{tabular}

Sumber: Data primer diolah (2014)

Tabel 14 di atas menunjukkan bahwa total keseluruhan IPK partisipan yang mengikuti ekperimen adalah 141 orang dengan rincian 2 
orang memiliki IPK $<3,00,31$ orang memiliki IPK 3,00 - 3,25, 56 orang

memiliki IPK 3,26 - 3,50, dan 52 orang memiliki IPK > 3,51.

\section{Statistik Deskriptif Mata Kuliah yang Sudah Lulus}

Tabel 15. Statistik Deskriptif Mata Kuliah yang Sudah Lulus

\begin{tabular}{|l|c|c|c|c|}
\hline & $\begin{array}{c}\text { Kelompok } \\
\text { Tidak Ada } \\
\text { Asimetri } \\
\text { Informasi }\end{array}$ & $\begin{array}{c}\text { Kelompok } \\
\text { Asimetri } \\
\text { Informasi } \\
\text { Rendah }\end{array}$ & $\begin{array}{c}\text { Kelompok } \\
\text { Asimetri } \\
\text { Informasi } \\
\text { Tinggi }\end{array}$ & Total \\
\hline $\begin{array}{l}\text { Akuntansi Manajemen, } \\
\text { Penganggaran, Sistem } \\
\begin{array}{l}\text { Pengendalian } \\
\text { Manajemen }\end{array}\end{array}$ & 25 & 23 & 23 & 71 \\
\hline $\begin{array}{l}\text { Akuntansi Manajemen, } \\
\text { Penganggaran }\end{array}$ & 21 & 24 & 25 & 70 \\
\hline \multicolumn{1}{|c|}{ Total } & 46 & 47 & 48 & 141 \\
\hline
\end{tabular}

Sumber: Data primer diolah (2014)

Tabel 15 di atas menunjukkan bahwa partisipan yang sudah lulus akuntansi manajemen, penganggaran, dan sistem pengendalian manajemen sebanyak 71 orang, sedangkan partisipan yang hanya lulus akuntansi manajemen dan penganggaran sebanyak 70 orang.

\section{Statistik Deskriptif Program Studi}

Tabel 16. Statistik Deskriptif Program Studi

\begin{tabular}{|l|c|c|c|c|}
\hline & $\begin{array}{c}\text { Kelompok } \\
\text { Tidak Ada } \\
\text { Asimetri } \\
\text { Informasi }\end{array}$ & $\begin{array}{c}\text { Kelompok } \\
\text { Asimetri } \\
\text { Informasi } \\
\text { Rendah }\end{array}$ & $\begin{array}{c}\text { Kelompok } \\
\text { Asimetri } \\
\text { Informasi } \\
\text { Tinggi }\end{array}$ & Total \\
\hline Akuntansi & 25 & 23 & 23 & 71 \\
\hline Program Studi & 21 & 24 & 25 & 70 \\
\hline Total & 46 & 47 & 48 & 141 \\
\hline
\end{tabular}

Sumber: Data primer diolah (2014)

Tabel 16 di atas menunjukkan bahwa partisipan yang mengambil program studi Akuntansi sebanyak 71 orang, sedangkan partisipan yang mengambil program studi Pendidikan Akuntansi sebanyak 71 orang. 


\section{B. Hasil Pilot Test}

Pilot test dilakukan untuk mengetahui apakah perlakuan yang diberikan dapat dimengerti oleh partisipan atau tidak. Pilot test melibatkan mahasiswa Akuntansi B 2010 Fakultas Ekonomi Universitas Negeri Yogyakarta. Pilot test dilakukan pada tanggal 22 April 2014 dengan melibatkan 30 orang. Peneliti membagi angket eksperimen dan juga kuesioner kepada 30 orang tersebut dengan pembagian 10 orang mengisi angket eksperimen perlakuan tidak ada asimetri informasi, 10 orang mengisi angket eksperimen perlakuan asimetri informasi rendah, dan 10 orang mengisi angket eksperimen perlakuan asimetri informasi tinggi. Setelah mengisi angket eksperimen, partisipan selanjutnya diminta mengisi kuesioner orientasi etika.

Mahasiswa yang berhasil mengisi manipulation check dengan benar dinyatakan lolos pilot test. Sebanyak 17 partisipan dinyatakan benar dalam menjawab manipulation check. Hal ini berarti 56,7\% dari partisipan pilot test yang bisa menjawab manipulation check dengan benar sehingga instrumen eksperimen belum cukup baik untuk digunakan untuk penelitian. Hal tersebut karena pernyataan dalam instrumen ambigu sehingga menyulitkan partisipan untuk menjawab dengan benar.

Peneliti melakukan pilot test kedua dengan menggunakan instrumen yang telah direvisi. Pilot test kedua dilakukan pada partisipan yang belum lolos manipulation check. Pilot test kedua dilakukanpada tanggal 28 April 2014. Pada pilot test kedua, sebanyak 9 partisipan dinyatakan benar dalam menjawab manipulation check. Total jumlah partisipan yang lolos manipulation check saat 
pilot test pertama dan kedua sebanyak 26 partisipan. Hal tersebut berarti $86,7 \%$ partisipan dapat memahami isi dari kasus yang diberikan oleh peneliti sehingga angket eksperimen dapat digunakan untuk penelitian.

\section{Statistik Deskriptif Variabel}

Statistik deskriptif dalam penelitian bertujuan untuk menggambarkan karakteristik demografis partisipan tanpa melakukan analisis (Sugiyono, 2010). Statistik deskripstif mengenai karakteristik demografis dalam penelitian ini dibuat untuk masing-masing variabel.

\section{Senjangan Anggaran}

Senjangan anggaran merupakan variabel dependen dalam penelitian ini. Senjangan anggaran adalah perbedaan antara perencanaan anggaran yang diajukan dengan estimasi terbaik manajer bawah, atau bisa juga diartikan mengajukan target anggaran di bawah kemampuan kinerja manajer bawah. Senjangan anggaran dihitung dengan menggunakan rumus:

$$
\begin{aligned}
& \text { Budgetary Slack }=\frac{\text { Hasil Produksi 3-Target Produksi }}{\text { ExpectedPerformance }} \\
& \text { Expected Performance }=\frac{\text { HasilProduksi 1+HasilProduksi } 2}{2}
\end{aligned}
$$

Berdasarkan data yang telah diolah maka hasil penghitungan analisis deskriptif untuk senjangan anggaran dapat dilihat di bawah ini.

\section{Tabel 17. Deskripsi Variabel Senjangan Anggaran}

\begin{tabular}{|c|c|c|c|c|c|}
\hline Variabel & Range & Mean & Min & Max & $\begin{array}{c}\text { Std. } \\
\text { Deviasi }\end{array}$ \\
\hline $\begin{array}{l}\text { Senjangan } \\
\text { Anggaran }\end{array}$ & 1,00 & 0,4109 & 0,00 & 1,00 & 0,28519 \\
\hline
\end{tabular}

Sumber: Data primer diolah (2014) 
Tabel 17 menunjukkan bahwa total rata-rata nilai senjangan anggaran sebesar 0,4109. Nilai senjangan anggaran minimum adalah 0,00, sedangkan nilai maksimum adalah 1,00 sehingga memiliki range sebesar 1,00 .

Selain menyajikan tabel berupa nilai maksimum, minimum, ratarata, dan standar deviasi, analisis deskriptif juga menyajikan data berupa tabel distribusi frekuensi. Langkah-langkah yang diperlukan dalam menyusun tabel distribusi frekuensi sebagai berikut:

1) Menghitung Jumlah Kelas Interval

Kelas interval dihitung dengan menggunakan rumus Sturges, yaitu jumlah kelas interval $=1+3,3 \log \mathrm{n}($ Sugiyono, 2010). Jumlah sampel (n) yang digunakan dalam penelitian ini adalah 141 sehingga kelas interval $=1+3,3 \log 141=8,092$ yang dibulatkan menjadi 8 .

2) Menghitung Rentang Data

Dari tabel di atas telah diketahui bahwa rentang data (range) senjangan anggaran adalah 1,00.

3) Menghitung Panjang Kelas

Penghitungan panjang kelas dapat dihitung dengan membagi rentang data dengan jumlah kelas, yaitu $1: 8=0,125$. Berdasarkan penghitungan tersebut maka dapat disusun tabel distribusi frekuensi senjangan anggaran sebagai berikut: 
Tabel 18. Distribusi Frekuensi Variabel Senjangan Anggaran

\begin{tabular}{|c|c|c|c|}
\hline No. & Kelas Interval & Frekuensi & Persentase (\%) \\
\hline 1. & $0,00-0,125$ & 22 & 15,6 \\
\hline 2. & $0,126-0,251$ & 29 & 20,57 \\
\hline 3. & $0,252-0,377$ & 19 & 13,48 \\
\hline 4. & $0,378-0,503$ & 24 & 17,02 \\
\hline 5. & $0,504-0,629$ & 13 & 9,22 \\
\hline 6. & $0,630-0,755$ & 13 & 9,22 \\
\hline 7. & $0,756-0,881$ & 12 & 8,51 \\
\hline 8. & $0,882-1,007$ & 9 & 6,38 \\
\hline
\end{tabular}

Sumber: Data primer diolah (2014)

Berdasarkan tabel distribusi frekuensi di atas maka dapat digambarkan histogram distribusi frekuensi senjangan anggaran sebagai berikut:

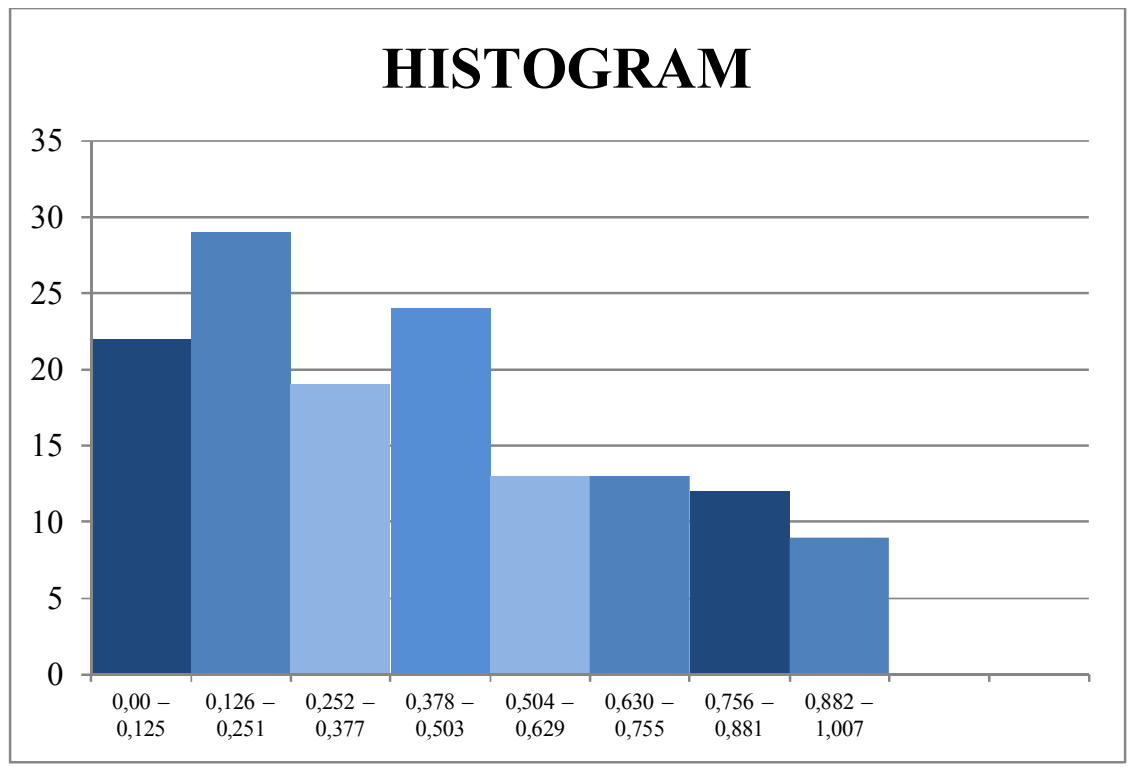

Gambar 2. Histogram Distribusi Frekuensi Senjangan Anggaran

Data di atas kemudian digolongkan ke dalam kategori kecenderungan data variabel senjangan anggaran. Kategori kecenderungan senjangan anggaran akan digolongkan menjadi rendah, sedang, dan tinggi 
(Anas, 2011). Pengkategorian didasarkan pada penghitungan antara ratarata ideal dan standar deviasi ideal dengan rumus sebagai berikut:

$$
\begin{array}{ll}
\text { Tinggi } & =\mathrm{M}+1 \mathrm{SD}<\mathrm{x} \\
\text { Sedang } & =\mathrm{M}-1 \mathrm{SD}=\mathrm{x}=\mathrm{M}+1 \mathrm{SD} \\
\text { Rendah } & =\mathrm{x}<\mathrm{M}-1 \mathrm{SD} \\
\mathrm{M} & =1 / 2(\text { skor tertinggi }+ \text { skor terendah) } \\
\mathrm{SD} & =1 / 6 \text { (skor tertinggi }- \text { skor terendah) }
\end{array}
$$

Nilai maksimum ideal sebesar 1,00 dan nilai minimum ideal sebesar 0,00 maka diperoleh hasil rata-rata sebesar $1 / 2(1,00+0,00)=0,5$ dan standar deviasi sebesar $1 / 6(1,00-0,00)=0,167$. Selanjutnya, kategori kecenderungan senjangan anggaran disajikan pada tabel berikut:

Tabel 19. Kategori Kecenderungan Senjangan Anggaran

\begin{tabular}{|c|c|c|c|}
\hline Interval & Kategori & Frekuensi & $\begin{array}{c}\text { Persentase } \\
(\mathbf{\%})\end{array}$ \\
\hline $0,667<\mathrm{x}$ & Tinggi & 34 & 24,11 \\
\hline $0,333=\mathrm{x}=0,667$ & Sedang & 39 & 27,66 \\
\hline $\mathrm{x}<0,333$ & Rendah & 68 & 48,23 \\
\hline
\end{tabular}

Sumber: Data primer diolah (2014)

Berdasarkan tabel 19 di atas maka dapat dilihat bahwa manajer bawah yang membuat senjangan anggaran pada kategori tinggi sebanyak 34 orang $(24,11 \%)$, manajer bawah yang membuat senjangan anggaran pada kategori sedang sebanyak 39 orang $(27,66 \%)$, dan manajer bawah yang membuat senjangan anggaran pada kategori rendah sebanyak 68 orang (48,23\%). Tabel di atas menunjukkan bahwa partisipan paling banyak melakukan senjangan anggaran pada kategori rendah. 


\section{Asimetri Informasi}

Asimetri informasi merupakan variabel independen dalam penelitian ini. Asimetri informasi merupakan perbedaan informasi yang dimiliki manajer atas dan manajer bawah mengenai unit tanggungjawab manajer bawah. Asimetri informasi pada penelitian ini menggunakan manipulasi perlakuan pada partisipan menurut tingkatan asimetri informasi, yaitu tidak ada asimetri informasi, asimetri informasi rendah, dan asimetri informasi tinggi.

Variabel independen asimetri informasi diukur dengan skor 0,1 , dan 2. Kondisi tidak ada asimetri informasi diberikan skor 0 , kondisi asimetri informasi rendah diberi skor 1, dan kondisi asimetri informasi tinggi diberi skor 2 .

Tabel 20. Skor Asimetri Informasi

\begin{tabular}{|c|c|}
\hline Asimetri Informasi & Skor \\
\hline Tidak Ada & 0 \\
\hline Rendah & 1 \\
\hline Tinggi & 2 \\
\hline
\end{tabular}

Sumber: Data primer diolah (2014)

Tabel 21. Distribusi Frekuensi Variabel Asimetri Informasi

\begin{tabular}{|cl|c|c|c|c|}
\hline & Frequency & Percent & $\begin{array}{c}\text { Valid } \\
\text { Percent }\end{array}$ & $\begin{array}{c}\text { Cumulative } \\
\text { Percent }\end{array}$ \\
\hline Valid & 0 & 46 & 32,6 & 32,6 & 32,6 \\
& 1 & 47 & 33,3 & 33,3 & 66,0 \\
& 2 & 48 & 34,0 & 34,0 & 100,0 \\
& Total & 141 & 100,0 & 100,0 & \\
\hline
\end{tabular}

Sumber: Data primer diolah (2014) 
Pada tabel 21 dapat dilihat bahwa partisipan yang mendapat perlakuan tidak ada asimetri informasi, asimetri informasi rendah, asimetri informasi tinggi tidak terlalu berbeda jauh jumlahnya.

Berdasarkan tabel distribusi frekuensi di atas, maka dapat digambarkan histogram distribusi frekuensi asimetri informasi sebagai berikut.

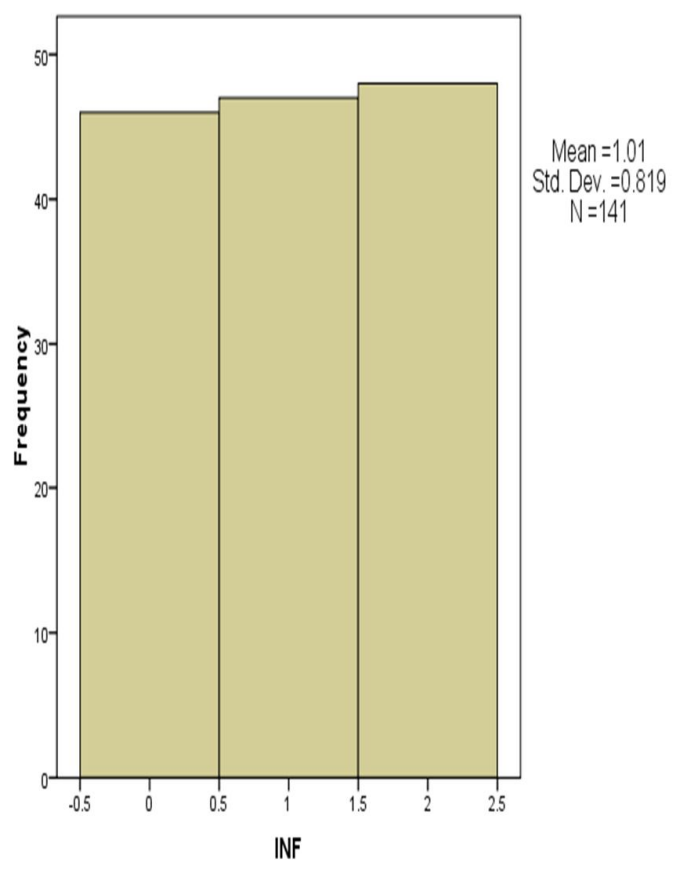

Gambar 3. Histogram Distribusi Frekuensi Asimetri Informasi

\section{Orientasi Etika}

Variabel orientasi etika pada penelitian ini sebagai variabel moderating. Orientasi etika dibagi menjadi dua bagian, yaitu relativisme dan idealisme. Variabel orientasi etika, yaitu relativisme dan idealisme diukur dengan 5 point skala likert di mana skor relativisme dan 
idealisme akan digunakan untuk menentukan partisipan memiliki relativisme dan idealisme rendah atau tinggi dengan menggunakan nilai median.

Partisipan dikategorikan memiliki relativisme dan idealisme rendah jika skor relativisme dan idealismenya di bawah nilai median, sedangkan partisipan dikategorikan memiliki relativisme dan idealisme tinggi jika skor untuk relativisme dan idealismenya berada di atas nilai median. Tingkat relativisme dan idealisme rendah diberi skor 0 , sedangkan tingkat relativisme dan idealisme tinggi diberi skor 1.

Selain membedakan partisipan menurut tingkatan relativisme dan idealisme, peneliti juga membagi partisipan menurut orientasi etika, yaitu gabungan antara tingkatan relativisme dan idealisme. Orientasi etika ditentukan berdasarkan tingkatan relativisme dan idealisme partisipan. Gabungan antara relativisme dan idealisme rendah dikategorikan sebagai exceptionist dan diberi skor 0. Gabungan antara relativisme rendah dan idealisme tinggi dikategorikan sebagai absolutist dan diberi skor 1 . Gabungan antara relativisme tinggi dan idealisme rendah dikategorikan sebagai subjectivist dan diberi skor 2. Gabungan antara relativisme dan idealisme tinggi dikategorikan situasionist dan diberi skor 3 . 
Tabel 22. Skor Orientasi Etika

\begin{tabular}{|l|l|c|}
\hline \multicolumn{2}{|c|}{ Orientasi Etika } & Skor \\
\hline \multirow{2}{*}{ Relativisme } & Rendah & 0 \\
\cline { 2 - 3 } & Tinggi & 1 \\
\hline \multirow{4}{*}{ Orientasisme } & Rendah & 0 \\
\cline { 2 - 3 } & Tinggi & 1 \\
\cline { 2 - 3 } & Exceptionist & 0 \\
\cline { 2 - 3 } & Absolutist & 1 \\
\cline { 2 - 3 } & Subjectivist & 2 \\
\cline { 2 - 3 } & Situationist & 3 \\
\hline
\end{tabular}

Sumber: Data primer diolah (2014)

Tabel 23. Mean dan Median Orientasi Etika

\begin{tabular}{|l|l|c|c|c|c|c|c|}
\hline \multicolumn{2}{|c|}{ Variabel } & Median & Mean & Range & $\begin{array}{c}\text { Std. } \\
\text { Deviasi }\end{array}$ & Min & Max \\
\hline Relativisme & 34 & 33,184 & 21 & 4,54124 & 23 & 44 \\
\hline Idealisme & 39 & 38,780 & 23 & 4,32780 & 26 & 49 \\
\hline Exceptionist & $\begin{array}{l}\text { Relativisme } \\
\text { Rendah }\end{array}$ & 30 & 29,636 & 10 & 2,85939 & 23 & 33 \\
\cline { 2 - 8 } & $\begin{array}{l}\text { Idealisme } \\
\text { Rendah }\end{array}$ & 36 & 35,090 & 12 & 2,51699 & 26 & 38 \\
\hline Absolutist & $\begin{array}{l}\text { Relativisme } \\
\text { Rendah }\end{array}$ & 30 & 29,405 & 10 & 3,06829 & 23 & 33 \\
\cline { 2 - 9 } & $\begin{array}{l}\text { Idealisme } \\
\text { Tinggi }\end{array}$ & 41 & 41,567 & 11 & 2,42144 & 39 & 48 \\
\hline Subjectivist & $\begin{array}{l}\text { Relativisme } \\
\text { Tinggi }\end{array}$ & 35,5 & 36,343 & 10 & 2,73106 & 34 & 44 \\
\cline { 2 - 9 } & $\begin{array}{l}\text { Idealisme } \\
\text { Rendah }\end{array}$ & 36 & 35,125 & 10 & 2,91548 & 28 & 38 \\
\hline Situationist & $\begin{array}{l}\text { Relativisme } \\
\text { Tinggi }\end{array}$ & 37 & 37,076 & 10 & 2,39939 & 34 & 44 \\
\cline { 2 - 8 } & $\begin{array}{l}\text { Idealisme } \\
\text { Tinggi }\end{array}$ & 41 & 42,128 & 10 & 2,88535 & 39 & 49 \\
\hline
\end{tabular}

Sumber: Data primer diolah (2014) 
Tabel 24. Distribusi Frekuensi Orientasi Etika

\begin{tabular}{|c|c|c|}
\hline Orientasi Etika & Frekuensi & Persentase (\%) \\
\hline Relativisme Rendah & 70 & 49,65 \\
\hline Relativisme Tinggi & 71 & 50,35 \\
\hline Total & 141 & 100 \\
\hline Idealisme Rendah & 65 & 46,1 \\
\hline Idealisme Tinggi & 76 & 53,9 \\
\hline Total & 141 & 100 \\
\hline Exceptionist & 33 & 23,40 \\
\hline Absolutist & 37 & 26,24 \\
\hline Subjectivist & 32 & 22,70 \\
\hline Situationist & 39 & 27,66 \\
\hline Total & 141 & 100 \\
\hline
\end{tabular}

Sumber: Data primer diolah (2014)

Pada tabel 23 di atas dapat dilihat bahwa relativisme memiliki nilai median 34, sedangkan idealisme memiliki nilai median 39. Variabel relativisme memiliki nilai minimum 23, sedangkan nilai maksimumnya 44. Variabel idealisme memiliki nilai minimum 26, sedangkan nilai maksimumnya 49.

Tipe exceptionist memiliki nilai minimum sebesar 23 untuk relativisme dan 26 untuk idealisme, sedangkan nilai maksimumnya 33 untuk relativisme dan 38 untuk idealisme. Tipe absolutist memiliki nilai minimum sebesar 23 untuk relativisme dan 39 untuk idealisme, sedangkan nilai maksimumnya 33 untuk relativisme dan 48 untuk idealisme. Tipe subjectivist memiliki nilai minimum 34 untuk relativisme dan 28 untuk idealisme, sedangkan nilai maksimumnya 44 untuk relativisme dan 38 untuk idealisme. Tipe situationist memiliki nilai minimum sebesar 34 untuk relativisme dan 39 untuk idealisme, sedangkan nilai maksimumnya 44 untuk relativisme dan 49 untuk idealisme. 
Tabel 24 menunjukkan partisipan yang memiliki relativisme rendah sebanyak 70 orang, sedangkan yang memiliki relativisme tinggi sebanyak 71 orang. Partisipan yang memiliki idealisme rendah sebanyak 65 orang, sedangkan partisipan yang memiliki idealisme tinggi sebanyak 76 orang. Partisipan exceptionist sebanyak 33 orang, absolutist sebanyak 37 orang, subjectivist sebanyak 32 orang, dan situationist sebanyak 39 orang.

Selain menyajikan tabel berupa nilai maksimum, minimum, mean, range, dan standar deviasi, analisis deskriptif juga menyajikan data berupa tabel distribusi frekuensi. Langkah-langkah yang diperlukan dalam menyusun tabel distribusi frekuensi sebagai berikut:

1) Menghitung Jumlah Kelas Interval

Kelas interval dihitung dengan menggunakan rumus Sturges, yaitu jumlah kelas interval $=1+3,3 \log n($ Sugiyono, 2010). Jumlah sampel (n) yang digunakan dalam penelitian ini adalah 141 sehingga kelas interval $=1+3,3 \log 141=8,092$ yang dibulatkan menjadi 8 .

2) Menghitung Rentang Data

Rentang data (range) yaitu data terbesar dikurangi data terkecil. Dari tabel di atas telah diketahui bahwa rentang data (range) relativisme adalah 21 , sedangkan range data idealisme adalah 23. 
3) Menghitung Panjang Kelas

Penghitungan panjang kelas dapat dihitung dengan membagi rentang data dengan jumlah kelas, yaitu $21: 8=2,625$ untuk relativisme, dibulatkan menjadi 2 , sedangkan $23: 8=2,875$ untuk idealisme, dibulatkan menjadi 2. Berdasarkan penghitungan tersebut maka dapat disusun tabel distribusi frekuensi relativisme dan idealisme sebagai berikut:

Tabel 25. Distribusi Frekuensi Variabel Relativisme

\begin{tabular}{|c|c|c|c|}
\hline No. & Kelas Interval & Frekuensi & Persentase \\
\hline 1. & $23-25$ & 9 & 6,38 \\
\hline 2. & $26-28$ & 11 & 7,8 \\
\hline 3. & $29-31$ & 27 & 19,15 \\
\hline 4. & $32-34$ & 41 & 29,08 \\
\hline 5. & $35-37$ & 29 & 20,57 \\
\hline 6. & $38-40$ & 19 & 13,48 \\
\hline 7. & $41-43$ & 2 & 1,42 \\
\hline 8. & $44-46$ & 3 & 2,13 \\
\hline
\end{tabular}

Sumber: Data primer diolah (2014)

Berdasarkan tabel 25 distribusi frekuensi di atas maka dapat digambarkan histogram distribusi frekuensi relativisme sebagai berikut: 


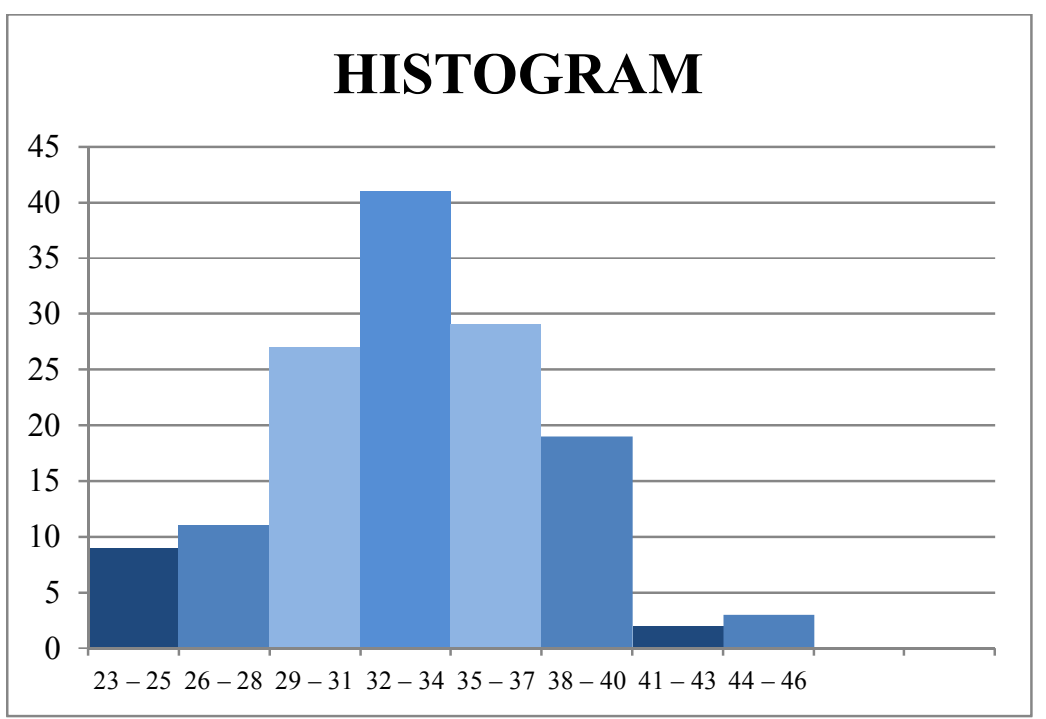

Gambar 4. Histogram Distribusi Frekuensi Variabel Relativisme

Tabel 26. Distribusi Frekuensi Variabel Idealisme

\begin{tabular}{|c|c|c|c|}
\hline No. & Kelas Interval & Frekuensi & Persentase (\%) \\
\hline 1. & $26-28$ & 3 & 2,13 \\
\hline 2. & $29-31$ & 4 & 2,84 \\
\hline 3. & $32-34$ & 15 & 10,64 \\
\hline 4. & $35-37$ & 34 & 24,11 \\
\hline 5. & $38-40$ & 40 & 28,37 \\
\hline 6. & $41-43$ & 24 & 17,02 \\
\hline 7. & $44-46$ & 16 & 11,35 \\
\hline 8. & $47-49$ & 5 & 3,55 \\
\hline
\end{tabular}

Sumber: Data primer diolah (2014)

Berdasarkan tabel 26 distribusi frekuensi di atas maka dapat digambarkan histogram distribusi frekuensi idealisme sebagai berikut: 


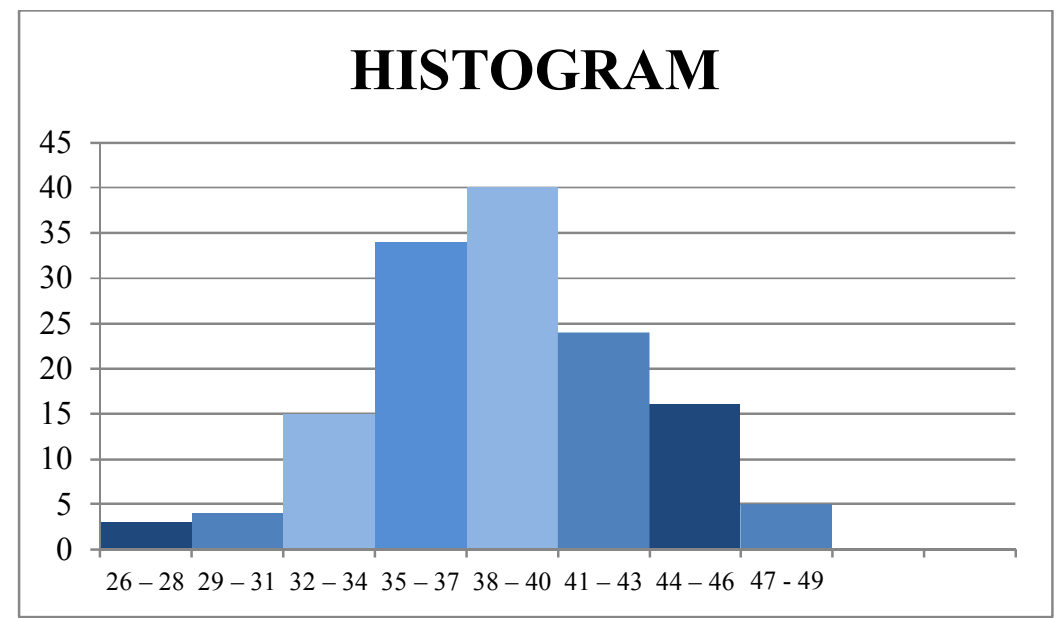

Gambar 5.Histogram Distribusi Frekuensi Idealisme

\section{Uji Validitas dan Reabilitas}

\section{Kuesioner Orientasi Etika}

Uji validitas dilakukan untuk mengetahui apakah instrumen yang digunakan mampu mengukur apa yang hendak diukur (Anwari, 2013). Pengujian validitas kuesioner orientasi etika, yaitu relativisme dan idealisme dilakukan dengan uji Pearson Correlation. Hasil uji Pearson Correlation dapat dilihat di bawah ini.

Tabel 27. Pearson Correlation Relativisme

\begin{tabular}{|c|c|c|}
\hline Butir Pertanyaan & Nilai Pearson Correlation & Keterangan \\
\hline$R E L 1$ & 0,513 & Valid \\
\hline$R E L 2$ & 0,747 & Valid \\
\hline$R E L 3$ & 0,525 & Valid \\
\hline$R E L 4$ & 0,509 & Valid \\
\hline$R E L 5$ & 0,592 & Valid \\
\hline$R E L 6$ & 0,867 & Valid \\
\hline$R E L 7$ & 0,760 & Valid \\
\hline$R E L 8$ & 0,645 & Valid \\
\hline$R E L 9$ & 0,645 & Valid \\
\hline$R E L 10$ & 0,609 & Valid \\
\hline
\end{tabular}

Sumber: Data primer diolah (2014) 
Tabel 28. Pearson Correlation Idealisme

\begin{tabular}{|c|c|c|}
\hline Butir Pertanyaan & Nilai Pearson Correlation & Keterangan \\
\hline$I D L 1$ & 0,529 & Valid \\
\hline$I D L 2$ & 0,615 & Valid \\
\hline$I D L 3$ & 0,626 & Valid \\
\hline$I D L 4$ & 0,573 & Valid \\
\hline$I D L 5$ & 0,379 & Valid \\
\hline$I D L 6$ & 0,556 & Valid \\
\hline$I D L 7$ & 0,466 & Valid \\
\hline$I D L 8$ & 0,445 & Valid \\
\hline$I D L 9$ & 0,661 & Valid \\
\hline$I D L 10$ & 0,626 & Valid \\
\hline
\end{tabular}

Sumber: Data primer diolah (2014)

Pengujian menggunakan signifikansi 0,05 dengan uji 2 sisi dan jumlah data $(n)=30$, sehingga diperoleh nilai $r$ tabel 0,361 . Kriteria pengujian uji Pearson Correlation sebagai berikut:

a. Jika $\mathrm{r}$ hitung $>\mathrm{r}$ tabel maka item-item pertanyaan dalam kuesioner berkorelasi signifikan terhadap skor total sehingga dapat dinyatakan valid.

b. Jika $\mathrm{r}$ hitung $<\mathrm{r}$ tabel maka item-item pertanyaan dalam kuesioner tidak berkorelasi secara signifikan terhadap skor total sehingga item-item pertanyaan tersebut dinyatakan tidak valid.

Tabel 27 dan tabel 28 di atas menunjukkan bahwa $\mathrm{r}$ hitung relativisme dan idealisme untuk masing-masing item pertanyaan lebih besar dari $r$ tabel, sehingga dapat dinyatakan bahwa kesepuluh item pertanyaan kuesioner tersebut valid. 
Setelah dilakukan uji validitas, selanjutnya dilakukan uji reabilitas untuk menguji apakah kuesioner reliabel atau tidak. Uji reabilitas dilakukan dengan menggunakan uji Cronbach's Alpha. Instrumen kuesioner dikatakan reliabel jika nilai Cronbach's Alpha lebih besar dari r tabel. Pengujian reabilitas menggunakan signifikansi 0,05 dengan uji 2 sisi dengan jumlah data $(n)=30$ sehingga diperoleh nilai $r$ tabel 0,361. Hasil uji reabilitas dapat dilihat pada tabel di bawah ini.

Tabel 29. Uji Reabilitas Relativisme dan Idealisme

\begin{tabular}{|l|c|c|}
\hline \multicolumn{1}{|c|}{ Variabel } & Cronbach's Alpha & Keterangan \\
\hline Relativisme & 0,841 & Reliabel \\
\hline Idealisme & 0,733 & Reliabel \\
\hline
\end{tabular}

Sumber: Data primer diolah (2014)

Hasil uji reabilitas menunjukkan bahwa intrumen kuesioner relativisme memiliki nilai Cronbach's Alpha sebesar 0,841, lebih besar dari r tabel, 0,361 sehingga instrumen kuesioner dapat dinyatakan reliabel sehingga dapat digunakan untuk penelitian. Hasil uji Cronbach's Alpha pada kuesioner idealisme menghasilkan nilai Cronbach's Alpha sebesar 0,733, lebih besar 0,361 sehingga instrumen kuesioner idealisme dapat dinyatakan reliabel. Hasil uji Cronbach's Alpha kuesioner relativisme dan idealisme menunjukkan angka 0,841 dan 0,733 dimana angka tersebut lebih besar dari 0,60 sehingga dapat dikatakan memiliki reabilitas tinggi (Anwar, 2013).

\section{Instrumen Perlakuan Asimetri Informasi}

Pengujian validitas instrumen treatment asimetri informasi dilakukan dengan face validity. Face validity adalah pengukuran validitas 
instrumen dengan cara melihat sepintas apakah instrumen yang digunakan sesuai dengan konsep variabel yang digunakan (Anwar, 2013). Face validity dilakukan dengan cara meminta beberapa orang untuk mengisi instrumen eksperimen dan meminta pendapat mereka untuk keperluan revisi.

\section{E. Uji Asumsi ANOVA}

\section{Uji Normalitas}

Uji normalitas dilakukan sebagai syarat dilakukannya uji two ways ANOVA, dimana untuk menggunakan uji two ways ANOVA asumsi data harus berdistribusi normal (Yusuf, 2000). Uji normalitas dilakukan pada tiga kasus asimetri informasi dan pada instrumen orientasi etika. Uji normalitas dilakukan dengan uji Kolmogorov-Smirnov dengan menggunakan taraf signifikansi 0,05. Data dikatakan berdistribusi normal jika nilai signifikansi lebih besar dari 0,05 . Hasil dari uji normalitas ditunjukkan pada tabel berikut:

Tabel 30. Hasil Uji Normalitas Senjangan Anggaran pada Tingkatan Asimetri Informasi

\begin{tabular}{|l|c|c|c|}
\hline \multicolumn{1}{|c|}{ Data } & $\begin{array}{c}\text { Kolmogorov- } \\
\text { Smirnov } Z\end{array}$ & Signifikan & Keterangan \\
\hline $\begin{array}{l}\text { Tidak Ada Asimetri } \\
\text { Informasi }\end{array}$ & 1,006 & 0,264 & Data Normal \\
\hline $\begin{array}{l}\text { Asimetri Informasi } \\
\text { Rendah }\end{array}$ & 0,775 & 0,585 & Data Normal \\
\hline $\begin{array}{l}\text { Asimetri Informasi } \\
\text { Tinggi }\end{array}$ & 1,660 & 0,777 & Data Normal \\
\hline
\end{tabular}

Sumber: Data primer diolah (2014) 
Tabel 31. Uji Normalitas Variabel Orientasi Etika

\begin{tabular}{|l|c|c|c|}
\hline \multicolumn{1}{|c|}{ Data } & $\begin{array}{c}\text { Kolmogorov- } \\
\text { Smirnov } \boldsymbol{Z}\end{array}$ & Signifikan & Keterangan \\
\hline Relativisme & 0,915 & 0,373 & Data Normal \\
\hline Idealisme & 0,870 & 0,436 & Data Normal \\
\hline
\end{tabular}

Sumber: Data primer diolah (2014)

Tabel 30 diatas menunjukkan bahwa data pada kasus tidak ada asimetri informasi, asimetri informasi rendah, dan asimetri informasi tinggi memiliki nilai signifikansi lebih besar dari 0,05 sehingga dapat dinyatakan bahwa data berdistribusi normal. Tabel 31 menunjukkan bahwa data orientasi etika memiliki nilai signifikansi lebih besar dari 0,05 sehingga dapat dinyatakan bahwa data berdistribusi normal.

\section{Uji Homogenitas Varians}

Uji homogenitas dilakukan untuk mengetahui apakah data dari ketiga kelompok perlakuan tidak ada asimetri informasi, asimetri informasi rendah, dan asimetri tinggi bersifat homogen atau tidak. Uji homogenitas varians menggunakan Lavene's Test. Data dinyatakan homogen ketika nilai signifikansi $>0,05$ (Efferin, Darmadji \& Tan, 2008). Hasil dari uji homogenitas varians dapat dilihat pada tabel 32 berikut:

Tabel 32. Uji Homogenitas Varians

\begin{tabular}{|l|c|c|}
\hline \multicolumn{1}{|c|}{ Variabel } & Sig. & Keterangan \\
\hline $\begin{array}{l}\text { Asimetri Informasi dan Senjangan } \\
\text { Anggaran }\end{array}$ & 0,314 & Data Homogen \\
\hline $\begin{array}{l}\text { Asimetri Informasi, Relativisme, dan } \\
\text { Senjangan Anggaran }\end{array}$ & 0,650 & Data Homogen \\
\hline $\begin{array}{l}\text { Asimetri Informasi, Idealisme, dan } \\
\text { Senjangan Anggaran }\end{array}$ & 0,717 & Data Homogen \\
\hline $\begin{array}{l}\text { Asimetri Informasi, Orientasi Etika, dan } \\
\text { Senjangan Anggaran }\end{array}$ & 0,785 & Data Homogen \\
\hline
\end{tabular}

Sumber: Data primer diolah (2014) 
Dari tabel 32 di atas, terlihat bahwa semua data bersifat homogen karena nilai signifikansinya lebih besar dari 0,05 . Hal ini berarti tidak ada perbedaan varians yang signifikan di antara kelompok-kelompok data tersebut.

\section{F. Uji Hipotesis}

Uji hipotesis yang digunakan dalam penelitian ini adalah ANOVA. Hipotesis-hipotesis yang diajukan dalam penelitian ini antara lain:

H1 = Terdapat perbedaan nilai senjangan anggaran pada tingkatan asimetri informasi.

$\mathrm{H} 2$ = Manajer yang memiliki relativisme tinggi akanmemiliki rata-rata nilai senjangan anggaran yang lebih tinggi dibandingkan dengan manajer yang memiliki relativisme rendah.

H3 = Manajer yang memiliki idealisme tinggi akanmemiliki rata-rata nilai senjangan anggaran yang lebih rendah dibandingkan dengan manajer yang memiliki idealisme rendah.

H4 = Terdapat perbedaan nilai senjangan anggaran pada tingkatan asimetri informasi berdasarkan orientasi etika.

\section{Pengaruh Asimetri Informasi terhadap Senjangan Anggaran}

\section{a. Pengujian Hipotesis}

Pengujian H1 dilakukan dengan one way ANOVA. Hipotesis akan diterima jika Fhitung $\geq$ Ftabel atau $p$-value kurang dari 0,05 $(<0,05)$, sedangkan hipotesis akan ditolak jika Fhitung $\leq$ Ftabel dan $p$ - 
value lebih dari $0,005(>0,05)$. Hasil pengujian H1 disajikan sebagai berikut:

Tabel 33. Tests of Between-Subjects Effects Asimetri Informasi

\begin{tabular}{|l|r|r|r|r|r|c|}
\hline \multicolumn{1}{|c|}{ Source } & $\begin{array}{c}\text { Type III } \\
\text { Sum of } \\
\text { Squares }\end{array}$ & $d f$ & $\begin{array}{c}\text { Mean } \\
\text { Square }\end{array}$ & $F$ & Sig. & Ket. \\
\hline $\begin{array}{l}\text { Corrected } \\
\text { Model }\end{array}$ & $2.441^{\mathrm{a}}$ & 2 & 1.220 & 18.826 & .000 & \\
\hline Intercept & 23.536 & 1 & 23.536 & 363.077 & .000 & \\
\hline INF & 2.441 & 2 & 1.220 & 18.826 & .000 & $\begin{array}{c}\text { H1 } \\
\text { Diterima }\end{array}$ \\
\hline Error & 8.946 & 138 & .065 & & & \\
\hline Total & 35.194 & 141 & & & & \\
\hline $\begin{array}{l}\text { Corrected } \\
\text { Total }\end{array}$ & 11.387 & 140 & & & & \\
\hline R Squared $=.214$ (Adjusted R Squared $=.203)$ & & \\
\hline
\end{tabular}

Sumber: Data primer diolah (2014)

Hipotesis satu memprediksi bahwa ada perbedaan rata-rata nilai senjangan anggaran pada tingkatan asimetri informasi. Tingkatan asimetri informasi membuat manajer bawah memiliki kecenderungan untuk membuat senjangan anggaran yang berbeda-beda. Pada kondisi tidak ada asimetri informasi, manajer bawah memiliki kecenderungan yang sangat rendah untuk membuat senjangan anggaran karena tidak memiliki kesempatan untuk membuat senjangan anggaran mengingat kemampuan kinerja manajer bawah diketahui oleh manajer atas. Karena memiliki kecenderungan yang sangat rendah maka pada kelompok tidak 
ada asimetri informasi akan memiliki rata-rata nilai senjangan anggaran yang sangat rendah.

Pada kondisi asimetri informasi rendah, manajer bawah memiliki kecenderungan untuk membuat senjangan anggaran yang rendah karena hanya memiliki kesempatan yang kecil mengingat kemampuan kinerja manajer bawah diketahui oleh manajer atas walaupun tidak semuanya diketahui oleh manajer atas. Karena memiliki kecenderungan yang rendah maka pada kelompok asimetri informasi rendah akan memiliki rata-rata nilai senjangan anggaran yang rendah. Namun, rata-rata nilai senjangan anggaran pada kelompok asimetri informasi rendah lebih besar daripada kelompok tidak ada asimetri informasi.

Pada kondisi asimetri informasi tinggi manajer atas memiliki kecenderungan untuk membuat senjangan anggaran yang tinggi karena memiliki kesempatan untuk membuat senjangan anggaran yang besar mengingat manajer atas tidak mengetahui kemampuan kinerja manajer bawah. Karena memiliki kecenderungan yang tinggi maka pada kelompok asimetri informasi tinggi akan memiliki rata-rata nilai senjangan anggaran yang tinggi.

Hasil pengujian H1 menunjukkan bahwa Fhitung sebesar 18,826 lebih besar dari Ftabel, yaitu 3,07. Nilai p-value signifikan karena $0,000<0,05$. Berdasarkan hasil Fhitung dan $p$-value dapat disimpulkan bahwa terdapat perbedaan nilai senjangan anggaran yang 
signifikan pada tingkatan asimetri informasi. Hal tersebut menunjukkan adanya pengaruh tingkatan asimetri informasi terhadap senjangan anggaran. Dengan demikian, H1 dinyatakan diterima.

Di bawah ini adalah tabel senjangan anggaran yang dibuat manajer bawah berdasarkan tingkatan asimetri informasi.

Tabel 34. Tabel Senjangan Anggaran Berdasarkan Asimetri Informasi

\begin{tabular}{|l|l|l|l|l|l|l|}
\hline $\begin{array}{c}\text { Asimetri } \\
\text { Informasi }\end{array}$ & Range & Mean & Min & Max & $\begin{array}{c}\text { Std. } \\
\text { Deviation }\end{array}$ & $\mathrm{N}$ \\
\hline Tidak Ada & 0,80 & 0,2464 & 0,00 & 0,80 & 0,23606 & 46 \\
\hline Rendah & 1,00 & 0,4107 & 0,00 & 1,00 & 0,24634 & 47 \\
\hline Tinggi & 1,00 & 0,5688 & 0,00 & 1,00 & 0,27855 & 48 \\
\hline Total & 1,00 & 0,4109 & 0,00 & 1,00 & 0,28519 & 141 \\
\hline
\end{tabular}

Sumber: Data diolah (2014)

Untuk melihat kelompok asimetri mana yang menunjukkan perbedaan rata-rata senjangan anggaran yang signifikan, peneliti menggunakan uji Post Hoc, yaitu uji Scheffe. Tabel di bawah menunjukkan perbedaan rata-rata nilai senjangan anggaran untuk kelompok tidak ada asimetri informasi, asimetri informasi rendah, dan asimetri informasi tinggi.

Tabel 35. Uji Post Hoc Asimetri Informasi

\begin{tabular}{|l|l|l|l|l|}
\hline \multicolumn{2}{|c}{ (I) INF } & \multicolumn{1}{c|}{ (J) INF } & $\begin{array}{c}\text { Mean } \\
\text { Difference }\end{array}$ & Sig. \\
\hline Scheffe & None & Low & -.1643 & .012 \\
& & High & -.3224 & .000 \\
\hline \multirow{4}{*}{ Low } & None & .1643 & .012 \\
& & High & -.1581 & .019 \\
\hline & High & None & .3224 & .000 \\
& & Low & .1581 & .019 \\
\hline
\end{tabular}

Sumber: Data primer diolah (2014) 
Berdasarkan tabel 35 di atas maka dapat dilihat bahwa ketiga uji Post Hoc menunjukkan bahwa kelompok tidak ada asimetri informasi, asimetri informasi rendah, dan asimetri informasi tinggi memiliki rata-rata nilai senjangan anggaran yang berbeda secara signifikan. Hal tersebut terlihat pada nilai signifikansi pada perbandingan masing-masing kelompok asimetri informasi yang lebih kecil dari 0,05.

Tabel di atas menunjukkan perbedaan rata-rata nilai senjangan anggaran yang signifikan pada kondisi tidak ada asimetri informasi dengan kondisi asimetri informasi rendah sebesar 0,1643 dengan signifikansi 0,012, rata-rata nilai senjangan anggaran yang signifikan pada kondisi tidak ada asimetri informasi dengan kondisi asimetri informasi tinggi sebesar 0,3224 dengan signifikansi 0,000, sedangkan perbedaan rata-rata nilai senjangan anggaran antara kelompok asimetri informasi rendah dan kelompok asimetri informasi tinggi sebesar 0,1581 dengan signifikansi 0,019. Hal tersebut menunjukkan bahwa tingkatan asimetri informasi menunjukkan kecenderungan untuk melakukan senjangan anggaran yang berbeda-beda.

Tabel di atas menunjukkan bahwa kelompok tidak ada asimetri informasi dan kelompok asimetri informasi tinggi memiliki selisih rata-rata nilai senjangan anggaran yang paling tinggi, yaitu 0,3224. Hal tersebut menunjukkan bahwa manajer bawah memiliki 
kecenderungan yang tinggi untuk melakukan senjangan anggaran pada kondisi asimetri informasi tinggi.

Rata-rata nilai senjangan anggaran pada tingkatan asimetri informasi dapat dilihat pada gambar grafik di bawah ini.

Estimated Marginal Means of SLACK

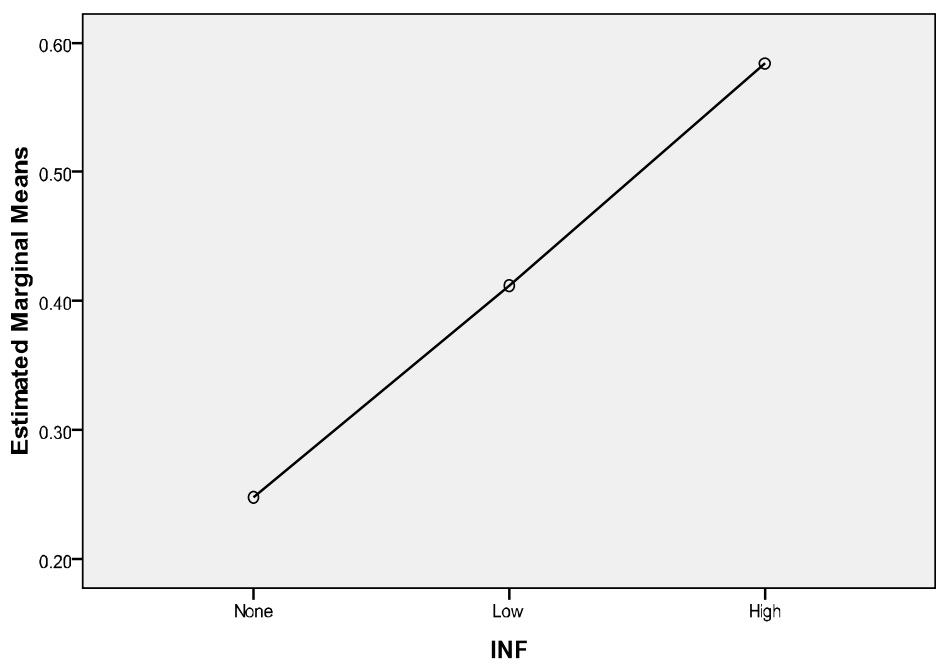

Gambar 6. Grafik Senjangan Anggaran pada Tingkatan Asimetri Informasi 
Di bawah ini adalah kategori senjangan anggaran yang dilakukan manajer bawah berdasarkan tingkatan asimetri informasi.

Tabel 36. Kategori Senjangan Anggaran pada Tingkatan Asimetri Informasi

\begin{tabular}{|c|c|c|c|}
\hline Asimetri Informasi & Kategori & Frekuensi & Persentase (\%) \\
\hline \multirow{3}{*}{$\begin{array}{l}\text { Tidak Ada Asimetri } \\
\text { Informasi }\end{array}$} & Tinggi & 5 & 10,87 \\
\hline & Sedang & 7 & 15,22 \\
\hline & Rendah & 34 & 73,91 \\
\hline \multicolumn{2}{|c|}{ Total } & 46 & 100 \\
\hline \multirow{3}{*}{$\begin{array}{l}\text { Asimetri Informasi } \\
\text { Rendah }\end{array}$} & Tinggi & 10 & 21,28 \\
\hline & Sedang & 15 & 31,91 \\
\hline & Rendah & 22 & 46,81 \\
\hline \multicolumn{2}{|c|}{ Total } & 47 & 100 \\
\hline \multirow{3}{*}{$\begin{array}{c}\text { Asimetri Informasi } \\
\text { Tinggi }\end{array}$} & Tinggi & 19 & 39,58 \\
\hline & Sedang & 17 & 35,42 \\
\hline & Rendah & 12 & 0,25 \\
\hline \multicolumn{2}{|c|}{ Total } & 48 & 100 \\
\hline
\end{tabular}

Sumber: Data primer diolah (2014)

Pada tabel 36 di atas dapat dilihat bahwa pada kelompok tidak ada asimetri informasi, sebanyak $73,91 \%$ partisipan melakukan senjangan anggaran pada kategori rendah. Hal ini menunjukkan bahwa pada kondisi tidak ada asimetri informasi dimana kesempatan untuk melakukan senjangan anggaran sangat kecil, partisipan cenderung membuat senjangan anggaran yang rendah.

Tabel di atas menunjukkan bahwa pada kelompok asimetri informasi rendah, senjangan anggaran pada kategori rendah masih yang paling tinggi, namun tidak sebesar persentase pada kelompok tidak ada asimetri informasi. Senjangan anggaran pada kategori sedang dan tinggi lebih banyak dilakukan pada kelompok asimetri informasi rendah. Hal ini menunjukkan bahwa peningkatan asimetri informasi membuat 
partisipan melakukan senjangan anggaran pada kategori sedang atau tinggi.

Pada kelompok asimetri informasi tinggi, senjangan anggaran pada kategori tinggi adalah yang paling tinggi dibandingkan kategori sedang dan rendah. Persentase senjangan anggaran pada kategori tinggi pada kelompok asimetri informasi tinggi lebih tinggi daripada pada kelompok asimetri informasi rendah. Hal ini menunjukkan bahwa asimetri informasi tinggi dimana kesempatan untuk melakukan senjangan anggaran sangat besar membuat partisipan cenderung membuat senjangan anggaran pada kategori tinggi.

\section{b. Koefisien Determinasi}

Koefisien determinasi digunakan untuk menjelaskan proporsi atau persentase variasi dalam variabel dependen yang dijelaskan oleh variabel independen secara bersama-sama. Koefisien determinasi $\left(\mathrm{R}^{2}\right)$ digunakan untuk mengetahui seberapa besar persentase pengaruh variabel asimetri informasi terhadap senjangan anggaran. Nilai koefisien determinasi adalah antara nol dan satu. Nilai koefisien determinasi $\left(\mathrm{R}^{2}\right)$ dilihat dari nilai Adjusted $R^{2}$ (Anwar, 2013).

Pada pengujian H1, peneliti menguji asimetri informasi terhadap senjangan anggaran. Model pengujian H1 menghasilkan nilai adjusted $R^{2}$ sebesar $20,3 \%$. Hal tersebut berarti variabel asimetri informasi mempengaruhi senjangan anggaran sebesar 20,3\%. Kecilnya 
persentase koefisien determinasi menunjukkan bahwa ada faktor-faktor lain yang mempengaruhi senjangan anggaran selain asimetri informasi.

\section{Pengaruh Tingkatan Relativisme pada Hubungan Asimetri Informasi terhadap Senjangan Anggaran}

Hipotesis kedua diuji dengan menggunakan two ways ANOVA. Hipotesis diuji dengan two ways ANOVA dengan mengukur main effect dan interaction effect dari variabel independen terhadap variabel dependen. Hipotesis akan diterima jika Fhitung $\geq$ Ftabel atau $p$-value kurang dari 0,05 $(<0,05)$, sedangkan hipotesis akan ditolak jika Fhitung $\leq$ Ftabel atau $p$ value lebih dari $0,005(>0,05)$.

Tabel 37. Senjangan Anggaran Berdasarkan Asimetri Informasi dan Relativisme

\begin{tabular}{|l|c|c|c|c|c|}
\hline & & $\begin{array}{c}\text { Tidak } \\
\text { Ada } \\
\text { Asimetri } \\
\text { Informasi }\end{array}$ & $\begin{array}{c}\text { Asimetri } \\
\text { Informasi } \\
\text { Rendah }\end{array}$ & $\begin{array}{c}\text { Asimetri } \\
\text { Informasi } \\
\text { Tinggi }\end{array}$ & Total \\
\hline \multirow{2}{*}{$\begin{array}{l}\text { Relativisme } \\
\text { Rendah }\end{array}$} & Mean & 0,2295 & 0,3509 & 0,5274 & 0,3783 \\
\cline { 2 - 6 } & $\mathrm{S} . \mathrm{D}$ & 0,22172 & 0,22063 & 0,28892 & 0,27513 \\
\cline { 2 - 6 } & $\mathrm{N}$ & 22 & 22 & 26 & 70 \\
\hline $\begin{array}{l}\text { Relativisme } \\
\text { Tinggi }\end{array}$ & Mean & 0,2619 & 0,4633 & 0,6176 & 0,4431 \\
\cline { 2 - 7 } & $\mathrm{S} . \mathrm{D}$ & 0,25223 & 0,25991 & 0,26392 & 0,29315 \\
\cline { 2 - 7 } & $\mathrm{N}$ & 24 & 25 & 22 & 71 \\
\hline
\end{tabular}

Sumber: Data primer diolah (2014)

Tabel 37 menunjukkan rata-rata nilai senjangan anggaran yang dilakukan partisipan yang memiliki relativisme rendah dan tinggi pada tingkatan asimetri informasi. Rata-rata nilai senjangan di atas akan diuji apakah signifikan atau tidak. Hasil pengujian disajikan berikut ini. 
Tabel 38. Tests of Between-Subjects Effects Asimetri Informasi dan Relativisme

\begin{tabular}{|l|r|r|r|r|r|r|}
\hline \multicolumn{1}{|c|}{ Source } & $\begin{array}{r}\text { Type III } \\
\text { Sum of } \\
\text { Squares }\end{array}$ & $d f$ & $\begin{array}{c}\text { Mean } \\
\text { Square }\end{array}$ & $F$ & Sig. & Ket. \\
\hline $\begin{array}{l}\text { Corrected } \\
\text { Model }\end{array}$ & $2.698^{\mathrm{a}}$ & 5 & .540 & 8.383 & .000 & \\
\hline Intercept & 23.415 & 1 & 23.415 & 363.811 & .000 & \\
\hline INF & 2.499 & 2 & 1.249 & 19.412 & .000 & \\
\hline REL & .215 & 1 & .215 & 3.347 & .070 & \\
\hline INF* REL & .040 & 2 & .020 & .307 & .736 & H2 \\
\hline Error & 8.689 & 135 & .064 & & & Ditolak \\
\hline Total & 35.194 & 141 & & & & \\
\hline $\begin{array}{l}\text { Corrected } \\
\text { Total }\end{array}$ & 11.387 & 140 & & & & \\
\hline
\end{tabular}

Sumber: Data primer diolah (2014)

Hipotesis H2 diuji dengan menginteraksikan variabel asimetri informasi dengan relativisme. Relativisme dibedakan menjadi dua jenis, yaitu rendah dan tinggi. Nilai median digunakan sebagai cut-off untuk menentukan tingkat relativisme partisipan (Abdullah, 2013; Forsyth \& Nye, 1990).

Hipotesis kedua menyatakan bahwa manajer bawah yang memiliki relativisme tinggi akan memiliki rata-rata nilai senjangan anggaran yang lebih tinggi daripada manajer bawah yang memiliki relativisme rendah. Pada tabel 38 menunjukkan bahwa interaksi antara asimetri informasi dan relativisme (INF*REL) memiliki Fhitung sebesar 0,307 lebih kecil daripada Ftabel, yaitu 3,07. Hasil p-value sebesar 0,736 dimana nilai tersebut lebih besar dari 0,05 yang berarti nilai tersebut menunjukkan perbedaan rata-rata senjangan anggaran yang tidak signifikan. Hasil pengujian menunjukkan 
bahwa tidak terdapat perbedaan rata-rata nilai senjangan anggaran pada tingkatan asimetri informasi berdasarkan tingkatan relativisme manajer bawah, dengan kata lain rata-rata nilai senjangan anggaran untuk tiap kelompok interaksi cenderung sama. Hal tersebut menunjukkan tidak ada efek interaksi antara asimetri informasi dan relativisme terhadap kecenderungan manajer bawah untuk melakukan senjangan anggaran.

Gambar grafik 7 menunjukkan bahwa manajer bawah yang memiliki relativisme tinggi membuat senjangan anggaran yang lebih tinggi daripada manajer bawah yang memiliki relativisme rendah. Walaupun begitu, hasil pengujian two ways ANOVA menunjukkan bahwa rata-rata nilai senjangan anggaran yang dibuat oleh manajer bawah yang memiliki relativisme tinggi dan manajer bawah yang memiliki relativisme rendah tidak berbeda secara signifikan. Berdasarkan pernyataan di atas maka dapat disimpulkan bahwa $\mathrm{H} 2$ ditolak.

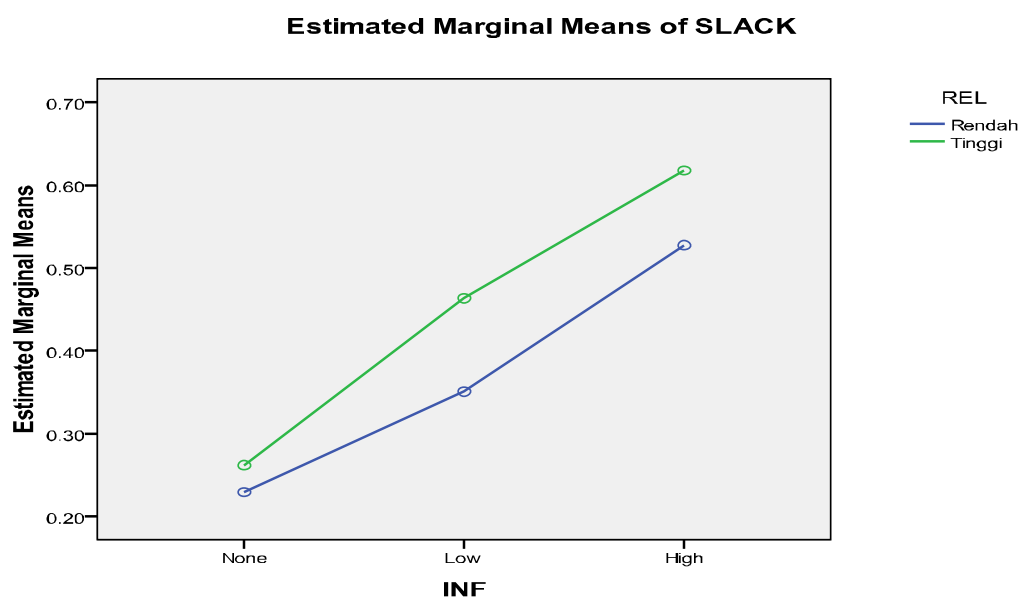

Gambar 7. Grafik Senjangan Anggaran Berdasarkan Relativisme 


\section{Pengaruh Tingkatan Idealisme pada Hubungan Asimetri Informasi terhadap Senjangan Anggaran}

Hipotesis ketiga diuji dengan menggunakan two ways ANOVA. Hipotesis diuji dengan two ways ANOVA dengan mengukur main effect dan interaction effect dari variabel independen terhadap variabel dependen. Hipotesis akan diterima jika Fhitung $\geq$ Ftabel atau $p$-value kurang dari 0,05 $(<0,05)$, sedangkan hipotesis akan ditolak jika Fhitung $\leq$ Ftabel atau $p$ value lebih dari $0,05(>0,05)$.

Hipotesis H3 diuji menggunakan two ways ANOVA dengan menginteraksikan variabel asimetri informasi dengan idealisme. Idealisme dibedakan menjadi dua jenis, yaitu rendah dan tinggi. Nilai median digunakan sebagai cut-off untuk menentukan tingkat idealisme partisipan (Abdullah, 2013; Forsyth \& Nye, 1990).

Tabel 39. Senjangan Anggaran Berdasarkan Idealisme dan Asimetri Informasi

\begin{tabular}{|l|c|c|c|c|c|}
\hline & & $\begin{array}{c}\text { Tidak Ada } \\
\text { Asimetri } \\
\text { Informasi }\end{array}$ & $\begin{array}{c}\text { Asimetri } \\
\text { Informasi } \\
\text { Rendah }\end{array}$ & $\begin{array}{c}\text { Asimetri } \\
\text { Informasi } \\
\text { Tinggi }\end{array}$ & Total \\
\hline \multirow{2}{*}{$\begin{array}{l}\text { Idealisme } \\
\text { Rendah }\end{array}$} & Mean & 0,2682 & 0,4546 & 0,6162 & 0,4515 \\
\cline { 2 - 6 } & $\mathrm{S} . \mathrm{D}$ & 0,25024 & 0,24638 & 0,28128 & 0,29412 \\
\cline { 2 - 6 } & $\mathrm{N}$ & 21 & 21 & 23 & 65 \\
\hline $\begin{array}{l}\text { Idealisme } \\
\text { Tinggi }\end{array}$ & Mean & 0,2281 & 0,3752 & 0,5252 & 0,3762 \\
\cline { 2 - 6 } & S.D & 0,22702 & 0,24530 & 0,27438 & 0,27450 \\
\hline
\end{tabular}

Sumber: Data primer diolah (2014)

Tabel 39 menunjukkan rata-rata nilai senjangan anggaran yang dilakukan partisipan yang memiliki idealisme rendah dan tinggi pada tingkatan asimetri informasi. Rata-rata nilai senjangan anggaran tersebut 
akan diuji apakah signifikan atau tidak. Hasil pengujian disajikan berikut ini.

Tabel 40. Tests of Between-Subjects Effects Asimetri Informasi dan Idealisme

\begin{tabular}{|l|r|r|r|r|r|r|}
\hline \multicolumn{1}{|l|}{ Dependent Variable:SLACK } & $\begin{array}{l}\text { Type III } \\
\text { Sum of } \\
\text { Squares }\end{array}$ & Df & $\begin{array}{c}\text { Mean } \\
\text { Square }\end{array}$ & \multicolumn{1}{c|}{$F$} & Sig. & Ket. \\
\hline $\begin{array}{l}\text { Source } \\
\text { Model }\end{array}$ & $2.631^{\mathrm{a}}$ & 5 & .526 & 8.115 & .000 & \\
\hline Intercept & 23.674 & 1 & 23.674 & 365.039 & .000 & \\
\hline INF & 2.432 & 2 & 1.216 & 18.748 & .000 & \\
\hline IDL & .172 & 1 & .172 & 2.654 & .106 & \\
\hline INF * IDL & .016 & 2 & .008 & .127 & .881 & H3 \\
\hline Error & 8.755 & 135 & .065 & & & Ditolak \\
\hline Total & 35.194 & 141 & & & & \\
\hline $\begin{array}{l}\text { Corrected } \\
\text { Total }\end{array}$ & 11.387 & 140 & & & & \\
\hline
\end{tabular}

Sumber: Data primer diolah (2014)

Hipotesis ketiga menyatakan bahwa manajer bawah yang memiliki idealisme tinggi akanmemiliki rata-rata nilai senjangan anggaran yang lebih rendah daripada manajer bawah yang memiliki idealisme rendah. Pada tabel 43 menunjukkan bahwa interaksi antara asimetri informasi dan idealisme (INF*IDL) memiliki Fhitung sebesar 0,127 lebih kecil daripada Ftabel, yaitu 3,07. Hasil p-value sebesar 0,881 dimana nilai tersebut lebih besar dari 0,05 yang berarti nilai tersebut menunjukkan perbedaan rata-rata senjangan anggaran yang tidak signifikan. Hasil pengujian menunjukkan bahwa tidak terdapat perbedaan rata-rata nilai senjangan anggaran pada tingkatan asimetri informasi berdasarkan tingkatan idealisme manajer bawah, dengan kata lain rata-rata nilai senjangan anggaran untuk tiap 
kelompok interaksi cenderung sama. Hal tersebut menunjukkan tidak ada efek interaksi antara asimetri informasi dan idealisme terhadap kecenderungan manajer bawah untuk melakukan senjangan anggaran.

Gambar grafik 8 menunjukkan bahwa manajer bawah yang memiliki idealisme tinggi membuat senjangan anggaran yang lebih rendah daripada manajer bawah yang memiliki idealisme rendah. Walaupun begitu, hasil pengujian two ways ANOVA menunjukkan bahwa rata-rata nilai senjangan anggaran yang dibuat oleh manajer bawah yang memiliki idealisme tinggi dan manajer bawah yang memiliki idealisme rendah tidak berbeda secara signifikan. Berdasarkan pernyataan di atas maka dapat disimpulkan bahwa H3 ditolak.

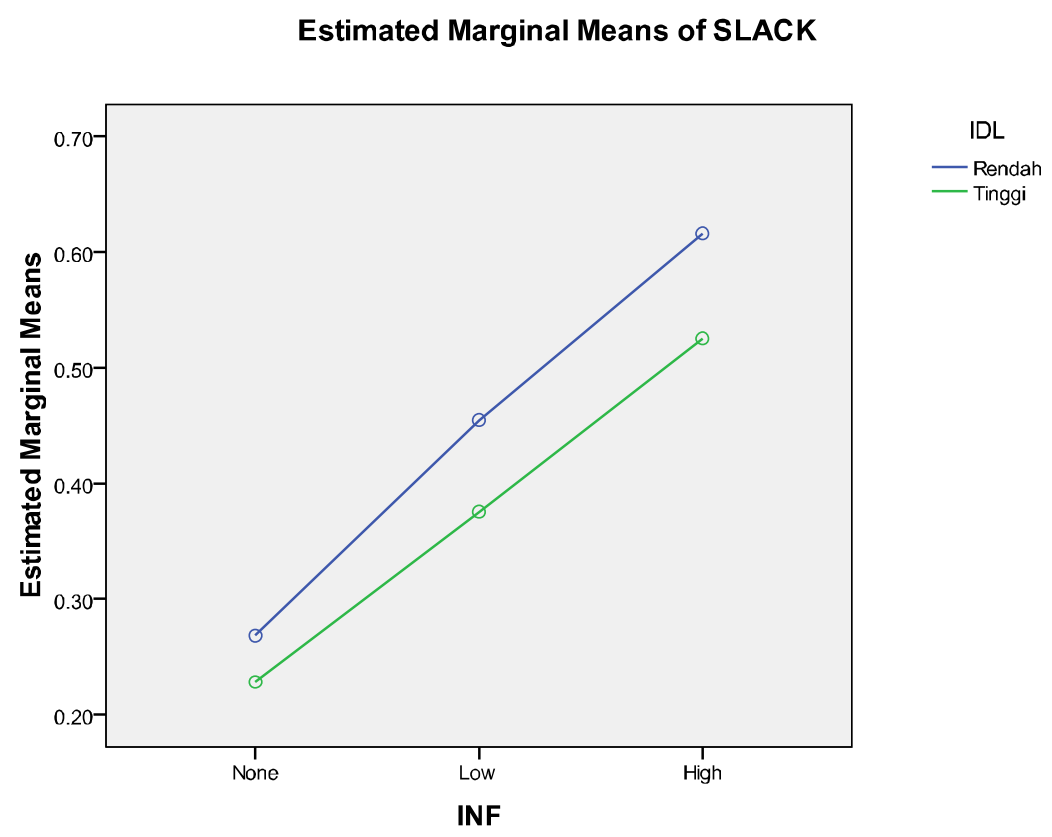

Gambar 8. Grafik Senjangan Anggaran Berdasarkan Idealisme 


\section{Pengaruh Tingkatan Orientasi Etika pada Hubungan Asimetri}

\section{Informasi terhadap Senjangan Anggaran}

Pengujian H4 dilakukan menggunakan uji two ways ANOVA dengan menginteraksikan variabel asimetri informasi sebagai main effect dengan orientasi etika sebagai interaction effect. Hipotesis akan diterima jika Fhitung $\geq$ Ftabel atau $p$-value kurang dari $0,05(<0,05)$, sedangkan hipotesis akan ditolak jika Fhitung $\leq$ Ftabel atau $p$-value lebih besar dari $0,05(>0,05)$.

Tabel 41. Senjangan Anggaran Berdasarkan Orientasi Etika dan Asimetri Informasi

\begin{tabular}{|c|c|c|c|c|c|}
\hline & & $\begin{array}{l}\text { Tidak Ada } \\
\text { Asimetri } \\
\text { Informasi }\end{array}$ & $\begin{array}{l}\text { Asimetri } \\
\text { Informasi } \\
\text { Rendah }\end{array}$ & $\begin{array}{c}\text { Asimetri } \\
\text { Informasi } \\
\text { Tinggi }\end{array}$ & Total \\
\hline \multirow{3}{*}{ Exceptionist } & Mean & 0,2586 & 0,4061 & 0,5487 & 0,4307 \\
\hline & S.D & 0,20873 & 0,25179 & 0,30430 & 0,28684 \\
\hline & $\mathrm{N}$ & 9 & 9 & 15 & 33 \\
\hline \multirow{3}{*}{ Absolutist } & Mean & 0,2094 & 0,3127 & 0,4985 & 0,3316 \\
\hline & S.D & 0,23646 & 0,19761 & 0,27830 & 0,25923 \\
\hline & $\mathrm{N}$ & 13 & 13 & 11 & 37 \\
\hline \multirow{3}{*}{ Subjectivist } & Mean & 0,2754 & 0,4910 & 0,7427 & 0,4731 \\
\hline & S.D & 0,28643 & 0,24676 & 0,18813 & 0,30450 \\
\hline & $\mathrm{N}$ & 12 & 12 & 11 & 32 \\
\hline \multirow{3}{*}{ Situationist } & Mean & 0,2484 & 0,4378 & 0,5462 & 0,4184 \\
\hline & S.D & 0,22491 & 0,27897 & 0,27988 & 0,28510 \\
\hline & $\mathrm{N}$ & 12 & 13 & 14 & 39 \\
\hline \multirow{3}{*}{ Total } & Mean & 0,2464 & 0,4107 & 0,5688 & 0,4109 \\
\hline & S.D & 0,23606 & 0,24634 & 0,27855 & 0,28519 \\
\hline & $\mathrm{N}$ & 46 & 47 & 48 & 141 \\
\hline
\end{tabular}

Sumber: Data primer diolah (2014)

Tabel 41 menunjukkan rata-rata nilai senjangan anggaran yang dilakukan exceptionist, absolutist, subjectivist, dan situationist pada tingkatan asimetri informasi. Rata-rata nilai senjangan anggaran tersebut 
akan diuji apakah signifikan atau tidak. Hasil pengujian disajikan berikut ini.

Tabel 42. Tests of Between-Subjects Effects Asimetri Informasi dan Orientasi Etika

\begin{tabular}{|c|c|c|c|c|c|c|}
\hline \multicolumn{7}{|c|}{ Dependent Variable:SLACK } \\
\hline Source & $\begin{array}{l}\text { Type III } \\
\text { Sum of } \\
\text { Squares }\end{array}$ & $d f$ & $\begin{array}{l}\text { Mean } \\
\text { Square }\end{array}$ & $F$ & Sig. & Ket \\
\hline Corrected Model & $2.992^{\mathrm{a}}$ & 11 & .272 & 4.179 & .000 & \\
\hline Intercept & 23.419 & 1 & 23.419 & 359.869 & .000 & \\
\hline$I N F$ & 2.550 & 2 & 1.275 & 19.593 & .000 & \\
\hline ORIENTASI & .447 & 3 & .149 & 2.290 & .081 & \\
\hline $\begin{array}{l}\text { INF * } \\
\text { ORIENTASI }\end{array}$ & .147 & 6 & .025 & .377 & .893 & $\begin{array}{l}\text { H4Dito } \\
\text { lak }\end{array}$ \\
\hline Error & 8.395 & 129 & .065 & & & \\
\hline Total & 35.194 & 141 & & & & \\
\hline Corrected Total & 11.387 & 140 & & & & \\
\hline
\end{tabular}

Sumber: Data primer diolah (2014)

Hipotesis keempat menyatakan bahwa terdapat perbedaan rata-rata nilai senjangan anggaran pada tingkatan asimetri informasi berdasarkan orientasi etika. Peneliti menguji H4 dengan menginteraksikan asimetri informasi dengan orientasi etika (INF*ORIENTASI). Pengujian H4 menunjukkan Fhitung sebesar 0,377 dimana nilai tersebut lebih kecil daripada Ftabel, yaitu 2,10. Hasil p-value sebesar 0,893 dimana nilai tersebut lebih besar dari 0,05 . Hal tersebut menunjukkan bahwa tidak ada perbedaan rata-rata nilai senjangan anggaran yang signifikan antara manajer bawah yang bertipe subjectivist, absolutist, situasionist, dan exceptionist. Manajer bawah yang memiliki tipe subjectivist, absolutist, situasionist, dan exceptionist memiliki kecenderungan yang sama untuk melakukan senjangan anggaran pada tingkatan asimetri informasi. Hal 
tersebut menunjukkan tidak ada efek interaksi antara asimetri informasi dan orientasi etika terhadap kecenderungan manajer bawah untuk melakukan senjangan anggaran. Berdasarkan pernyataan di atas maka disimpulkan bahwa $\mathrm{H} 4$ dinyatakan ditolak.

Di bawah ini adalah tabel perbandingan rata-rata nilai senjangan anggaran tipe subjectivist, absolutist, situasionist, dan exceptionist.

Tabel 43. Uji Post Hoc Orientasi Etika

\begin{tabular}{|c|c|c|c|c|}
\hline \multicolumn{5}{|c|}{ Dependent Variable:SLACK } \\
\hline & $\begin{array}{c}\text { (I) } \\
\text { ORIENTASI }\end{array}$ & $\begin{array}{c}(\mathrm{J}) \\
\text { ORIENTASI }\end{array}$ & $\begin{array}{c}\text { Mean } \\
\text { Difference (I-J) }\end{array}$ & Sig. \\
\hline \multirow[t]{12}{*}{ Scheffe } & \multirow[t]{3}{*}{ Exceptionist } & Absolutist & .0991 & .455 \\
\hline & & Subjectivist & -.0424 & .930 \\
\hline & & Situationist & .0122 & .998 \\
\hline & \multirow[t]{3}{*}{ Absolutist } & Exceptionist & -.0991 & .455 \\
\hline & & Subjectivist & -.1415 & .158 \\
\hline & & Situationist & -.0868 & .534 \\
\hline & \multirow[t]{3}{*}{ Subjectivist } & Exceptionist & .0424 & .930 \\
\hline & & Absolutist & .1415 & .158 \\
\hline & & Situationist & .0546 & .848 \\
\hline & \multirow[t]{3}{*}{ Situationist } & Exceptionist & -.0122 & .998 \\
\hline & & Absolutist & .0868 & .534 \\
\hline & & Subjectivist & -.0546 & .848 \\
\hline
\end{tabular}

Sumber: Data primer diolah (2014)

Tabel 43 di atas menunjukkan bahwa orientasi etika tidak memiliki perbedaan rata-rata nilai senjangan anggaran yang signifikan. Hal tersebut dilihat pada nilai signifikansi yang lebih besar dari 0,05. Hal ini menunjukkan bahwa orientasi etika tidak berpengaruh pada senjangan anggaran. 


\section{Estimated Marginal Means of SLACK}

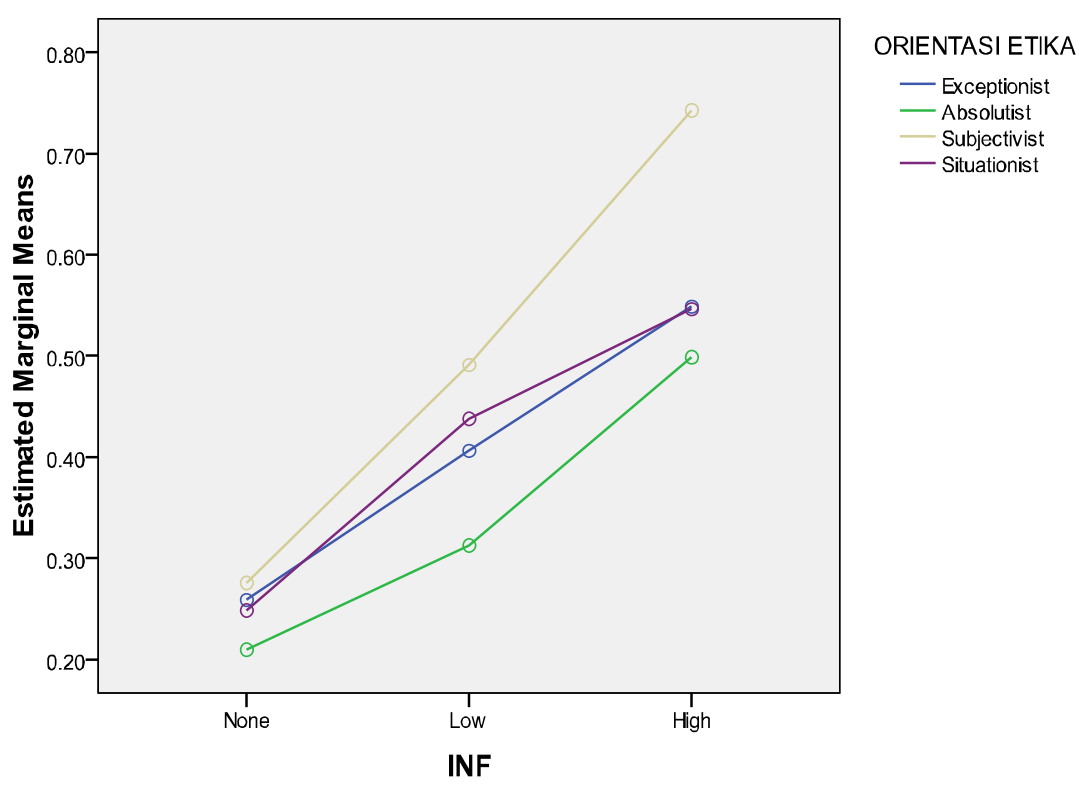

Gambar 9. Grafik Senjangan Anggaran Exceptionist, Absolutist,

\section{Subjectivist, dan Situationist}

Grafik di atas menunjukkan bahwa subjectivist memiliki rata-rata nilai senjangan anggaran yang paling tinggi, exceptionist dan situationist memiliki rata-rata nilai senjangan anggaran yang sedang, sedangkan absolutist memiliki rata-rata nilai senjangan anggaran yang paling rendah.

Walaupun begitu, berdasarkan uji Post Hoc di atas, selisih antara rata-rata nilai senjangan anggaran yang dilakukan subjectivist dengan ratarata nilai senjangan anggaran yang dilakukan absolutist tidak menunjukkan hasil yang signifikan sehingga dapat dikatakan tingkatan asimetri informasi membuat subjectivist, absolutist, exceptionist dan 
situationist memiliki kecenderungan yang sama untuk melakukan senjangan anggaran.

\section{G. Pembahasan}

\section{Pengaruh Asimetri Informasi terhadap Senjangan Anggaran}

Hasil pengujian $\mathrm{H} 1$ menunjukkan adanya perbedaan rata-rata nilai senjangan anggaran pada tingkatan asimetri informasi dengan Fhitung sebesar 18,826 lebih besar dari Ftabel, yaitu 3,07. Hasil p-value sebesar $0,000$ ( $p$-value $<0,05)$ yang menyatakan signifikan. Hasil dari pengujian tersebut membuktikan bahwa tingkatan asimetri informasi berpengaruh terhadap senjangan anggaran.

Hasil uji Post Hoc menunjukkan bahwa selisih rata-rata nilai senjangan anggaran antara kelompok tidak ada asimetri informasi dengan kelompok asimetri informasi tinggi adalah yang paling tinggi daripada selisih rata-rata nilai senjangan anggaran antara kelompok tidak ada asimetri informasi dengan kelompok asimetri informasi rendah, yaitu $0,3224>0,1643$. Hal tersebut menunjukkan bahwa pada kondisi asimetri informasi tinggi manajer bawah memiliki kecenderungan untuk melakukan senjangan anggaran yang tinggi.

Asimetri informasi muncul karena perbedaan informasi antara manajer bawah dengan manajer atas mengenai informasi unit tanggungjawab manajer bawah.Informasi tersebut dalam penelitian ini diartikan sebagai informasi mengenai kemampuan kinerja manajer bawah dalam mengoperasikan unit tanggungjawabnya. Semakin tinggi tingkat 
asimetri informasi maka semakin tinggi pula ketidaktahuan manajer atas mengenai kemampuan kinerja manajer bawah.

Adanya asimetri informasi memunculkan kebijakan penganggaran partisipatif dimana manajer bawah ikut terlibat dalam penyusunan anggaran dan memiliki pengaruh dalam menentukan anggaran akhir. Penganggaran partisipatif dilakukan agar manajer bawah dapat memberikan informasi yang dimilikinya terkait unit tanggungjawab yang dibawahinya dimana informasi tersebut sangat diperlukan untuk membuat anggaran yang optimal.

Walaupun partisipasi anggaran sebenarnya bertujuan untuk mendapatkan informasi dari manajer bawah, namun, terkadang manajer bawah sering memanfaatkan adanya kebijakan partisipasi anggaran untuk membuat senjangan anggaran agar target anggaran lebih rendah dari kemampuan kinerja yang sesungguhnya. Hal tersebut dilakukan manajer bawah untuk mendapat keuntungan pribadi atau dengan alasan lainnya.

Dalam penelitian ini, peneliti memasukkan insentif untuk memicu dimanfaatkannya asimetri informasi oleh manajer bawah. Hasil penelitian menunjukkan bahwa manajer bawah memanfaatkan adanya asimetri informasi untuk melakukan senjangan anggaran untuk mendapatkan insentif.

Dimanfaatkannya asimetri informasi untuk melakukan senjangan anggaran menunjukkan adanya perbedaan tujuan atau kepentingan antara manajer bawah dengan manajer atas. Hal ini sesuai dengan teori agensi 
dimana dalam teori agensi menyebutkan bahwa manajer bawah dan manajer atas memiliki perbedaan kepentingan. Manajer atas berorientasi dalam meningkatkan kinerja perusahaan, sedangkan manajer atas lebih berorientasi pada insentif yang bisa didapat. Hal tersebut terbukti pada hasil penelitian bahwa adanya insentif yang diberikan manajer atas akan membuat manajer bawah melakukan senjangan anggaran ketika dihadapkan pada kondisi asimetri informasi.

Hasil penelitian sesuai dengan pendapat Anthony \& Govindarajan (2005) yang menyatakan bahwa perbedaan tujuan antara manajer atas dan manajer bawah dapat menyebabkan manajer bawah salah menyajikan informasi kepada manajer atas. Manajer bawah salah menyajikan informasi kepada manajer atas karena manajer bawah memberikan informasi yang bukan sebenarnya. Hal tersebut bertujuan agar anggaran yang ditetapkan mudah dicapai.

Pada penganggaran partisipatif, semakin tingginya tingkatan asimetri informasi maka akan dimanfaatkan oleh manajer bawah untuk melakukan senjangan anggaran. Hal tersebut karena semakin tinggi tingkatan senjangan anggaran maka semakin tinggi pula kesempatan yang dimiliki manajer bawah untuk melakukan senjangan anggaran karena manajer atas tidak mengetahui kemampuan kinerjanya.

Hasil penelitian ini sesuai dengan hasil penelitian Stevens (2002) yang dalam penelitiannya menemukan bahwa asimetri informasi memiliki pengaruh terhadap senjangan anggaran. Stevens (2002) meneliti mengenai 
pengaruh etika dan reputasi terhadap senjangan anggaran jika dihadapkan pada tingkatan asimetri informasi.

Hasil penelitian ini tidak sesuai dengan penelitian yang dilakukan Elizabeth (2014) dimana hasil penelitiannya menunjukkan bahwa asimetri informasi berhubungan negatif terhadap senjangan anggaran. Hal tersebut karena peran audit internal, yaitu pihak independen untuk menjamin keakurat pengungkapan laporan keuangan. Laporan keuangan yang sudah dicek oleh audit internal lalu akan disampaikan kepada manajer atas sehingga mengurangi asimetri informasi antara manajer atas dengan manajer bawah.

\section{Pengaruh Orientasi Etika pada Hubungan Asimetri Informasi terhadap Senjangan Anggaran}

Hipotesis kedua menyatakan bahwa manajer bawah yang memiliki relativisme tinggi akan memiliki rata-rata nilai senjangan anggaran yang lebih tinggi daripada manajer bawah yang memiliki relativisme rendah. Hasil pengujian menunjukkan bahwa interaksi antara asimetri informasi dan relativisme (INF*REL) memiliki Fhitung sebesar 0,307 lebih kecil daripada Ftabel, yaitu 3,07. Hasil p-value sebesar 0,736 dimana nilai tersebut lebih besar dari 0,05 yang menunjukkan tidak signifikan.

Hasil pengujian tersebut menunjukkan bahwa tidak ada perbedaan rata-rata nilai senjangan anggaran yang signifikan antara manajer bawah 
yang memiliki relativisme rendah dengan manajer bawah yang memiliki relativisme tinggi pada tingkatan asimetri informasi ( $\mathrm{H} 2$ ditolak).

Individu yang memiliki relativisme tinggi seharusnya memiliki ratarata nilai senjangan anggaran yang lebih tinggi daripada individu yang memiliki relativisme rendah karena individu yang memiliki relativisme tinggi akan lebih mempertimbangkan pendapat pribadi dalam menilai etis atau tidaknya senjangan anggaran daripada harus patuh pada aturan moral secara umum. Namun, hal tersebut tidak terbukti pada pengujian H2.

Hasil pengujian $\mathrm{H} 2$ tidak sesuai dengan hasil penelitian yang dilakukan Abdullah (2012), dimana hasil penelitiannya menyatakan bahwa relativisme berpengaruh pada senjangan anggaran. Abdullah (2012) meneliti mengenai pengaruh horizontal equity dan self efficacy terhadap senjangan anggaran dengan orientasi etika sebagai variabel moderating.

Hipotesis ketiga menyatakan bahwa manajer bawah yang memiliki idealisme tinggi akanmemiliki rata-rata nilai senjangan anggaran lebih rendah daripada manajer bawah yang memiliki idealisme rendah. Hasil pengujian menunjukkan bahwa interaksi antara asimetri informasi dan idealisme (INF*IDL) memiliki Fhitung sebesar 0,127 lebih kecil daripada Ftabel, yaitu 3,07. Hasil p-value sebesar 0,736 dimana nilai tersebut lebih besar dari 0,05 yang berarti nilai tersebut menunjukkan perbedaan rata-rata senjangan anggaran yang tidak signifikan.

Hasil pengujian menunjukkan bahwa tidak terdapat perbedaan ratarata nilai senjangan anggaran yang signifikan antara manajer bawah yang 
memiliki idealisme tinggi dengan manajer bawah yang memiliki idealisme rendah pada tingkatan asimetri informasi. Individu yang memiliki idealisme tinggi seharusnya memiliki rata-rata nilai senjangan anggaran yang lebih rendah daripada individu yang memiliki idealisme rendah karena individu yang memiliki idealisme tinggi akan menghindari senjangan anggaran karena menganggap senjangan anggaran dapat merugikan perusahaan. Namun, hal tersebut tidak terbukti pada pengujian $\mathrm{H} 3$.

Hasil pengujian H3 sesuai dengan hasil penelitian Abdullah (2012) dimana hasil penelitiannya menyatakan bahwa idealisme tidak mempengaruhi senjangan anggaran. Namun, penelitian ini tidak sesuai dengan penelitian yang dilakukan Kung \& Li Huang (2010) dimana idealisme berhubungan negatif terhadap tindakan tidak etis.

Hipotesis keempat menyatakan bahwa terdapat perbedaan rata-rata nilai senjangan anggaran pada tingkatan asimetri informasi berdasarkan orientasi etika. Pengujian H4 menunjukkan Fhitung sebesar 0,377 dimana nilai tersebut lebih kecil daripada Ftabel, yaitu 2,10. Hasil p-value sebesar 0,893 dimana nilai tersebut lebih besar dari 0,05. Hal tersebut menunjukkan bahwa tidak ada perbedaan rata-rata nilai senjangan anggaran yang signifikan antara manajer bawah yang bertipe subjectivist, absolutist, situasionist, dan exceptionist. Manajer bawah yang memiliki tipe subjectivist, absolutist, situasionist, dan exceptionist memiliki kecenderungan yang sama untuk melakukan senjangan anggaran pada tingkatan asimetri informasi. Dengan demikian, hasil pengujian 
menunjukkan tidak ada efek interaksi antara asimetri informasi dan orientasi etika terhadap kecenderungan manajer bawah untuk melakukan senjangan anggaran. Berdasarkan hasil pengujian di atas maka H4 ditolak.

Hasil pengujian $\mathrm{H} 4$ sesuai dengan hasil penelitian yang dilakukan Abdullah (2012) yang menyatakan bahwa orientasi etika tidak berpengaruh signifikan terhadap senjangan anggaran karena tidak memiliki perbedaan rata-rata senjangan anggaran yang signifikan. Hasil pengujian di atas tidak sesuai dengan penelitian yang dilakukan Kung \& Li Huang (2010) yang menyatakan bahwa orientasi etika berpengaruh signifikan terhadap tindakan tidak etis.

Hasil penelitian $\mathrm{H} 2, \mathrm{H} 3, \mathrm{H} 4$ tersebut tidak membuktikan pengaruh orientasi etika (relativisme dan idealisme) terkait kecenderungan dalam melakukan senjangan anggaran jika dihadapkan pada kondisi asimetri informasi. Manajer bawah yang memiliki relativisme dan idealisme rendah ataupun tinggi memiliki kecenderungan yang sama untuk melakukan senjangan anggaran pada kondisi asimetri informasi.

Ketika seseorang dihadapkan pada suatu dilema etika mengenai suatu tindakan maka individu tersebut akan mempertimbangkan tindakan tersebut secara kognitif. Selama mempertimbangkan suatu tindakan tersebut, individu akan mengidentifikasi isu moral (moral issue) terkait tindakan tersebut lalu akan membuat penilaian etis atau tidaknya tindakan tersebut. Penilaian etis yang dilakukan individu akan memunculkan 
motivasi untuk melakukan atau tidak melakukan suatu tindakan yang kemudian motivasi tersebut diwujudkan dalam perbuatan (moral behavior).

Pada proses pembuatan keputusan etis seperti di atas, tidak hanya dipengaruhi oleh faktor personal, seperti orientasi etika, tetapi juga faktor situasional. Hal ini yang menjadi kemungkinan penyebab tidak adanya perbedaan rata-rata nilai senjangan anggaran yang signifikan antara manajer bawah yang memiliki relativisme dan idealisme tinggi ataupun rendah. Jadi, walaupun individu menilai senjangan anggaran adalah perbuatan tidak etis, namun individu tersebut tetap melakukan senjangan anggaran. Faktor situasional di sini seperti lingkungan sosial, budaya etis organisasi, dan adanya kesempatan (Ferrel \& Gresham, 1985).

Pendapat Ferrel \& Gresham (1985) menjadi penegas bahwa ketika manajer bawah yang memiliki idealisme tinggi atau memiliki relativisme rendah ketika dihadapkan pada kondisi asimetri informasi dan adanya insentif yang diberikan manajer atas maka manajer bawah akan memiliki kecenderungan yang tidak berbeda dengan manajer bawah yang memiliki idealisme rendah dan relativisme tinggi.

Manajer bawah yang memiliki idealisme tinggi atau relativisme rendah akan memiliki kecenderungan yang tinggi untuk menilai senjangan anggaran termasuk perbuatan yang tidak etis sehingga akan menghindarinya, namun motivasi untuk tidak melakukan senjangan anggaran tersebut kemungkinan bisa berubah karena adanya kesempatan yang dimiliki manajer bawah. Manajer bawah memiliki kesempatan untuk 
melakukan senjangan anggaran dengan memanfaatkan kondisi asimetri informasi untuk mendapatkan insentif. 


\section{BAB V}

\section{KESIMPULAN DAN SARAN}

\section{A. Kesimpulan}

Penelitian ini bertujuan untuk memberikan bukti empiris mengenai pengaruh tingkat asimetri informasi terhadap senjangan anggaran dengan orientasi etika sebagai variabel moderating. Berdasarkan analisis yang telah dilakukan mengenai pengaruh asimetri informasi terhadap senjangan anggaran berdasarkan orientasi etika maka peneliti menarik kesimpulan sebagai berikut:

1. Asimetri informasi berpengaruh terhadap senjangan anggaran karena terdapat perbedaan rata-rata nilai senjangan anggaran pada tingkatan asimetri informasi. Hal tersebut ditunjukkan oleh Fhitung sebesar 18,826 lebih besar dari Ftabel, yaitu 3,07 dan p-value sebesar 0,000 $<0,05$ yang menunjukkan signifikan.

2. Asimetri informasi tinggi membuat manajer bawah melakukan senjangan anggaran yang paling tinggi. Hal tersebut terlihat pada uji Post Hoc yang menunjukkan kelompok asimetri informasi tinggi memiliki selisih ratarata nilai senjangan anggaran yang paling tinggi dengan kelompok tidak ada asimetri informasi, yaitu sebesar 0,3224 dengan signifikansi 0,000< 0,05 .

3. Relativisme tidak berpengaruh pada hubungan asimetri informasi terhadap senjangan anggaran. Hal tersebut terlihat pada hasil Fhitung sebesar 0,307 lebih kecil daripada Ftabel, yaitu 3,07. Hasil p-value sebesar 0,736 dimana 
nilai tersebut lebih besar dari 0,05 yang berarti nilai tersebut menunjukkan perbedaan rata-rata senjangan anggaran yang tidak signifikan.

4. Idealisme tidak berpengaruh pada hubungan asimetri informasi terhadap senjangan anggaran. Hal tersebut terlihat pada hasil Fhitung sebesar 0,127 lebih kecil daripada Ftabel, yaitu 3,07. Hasil p-value sebesar 0,881 dimana nilai tersebut lebih besar dari 0,05 yang berarti nilai tersebut menunjukkan perbedaan rata-rata senjangan anggaran yang tidak signifikan.

5. Orientasi etika tidak berpengaruh pada hubungan asimetri informasi terhadap senjangan anggaran. Hal tersebut ditunjukkan oleh hasil Fhitung sebesar 0,127 lebih kecil daripada Ftabel, yaitu 3,07. Hasil p-value sebesar 0,893 dimana nilai tersebut lebih besar dari 0,05 yang berarti nilai tersebut menunjukkan perbedaan rata-rata senjangan anggaran yang tidak signifikan.

\section{B. Kontribusi Penelitian}

Penelitian ini memberikan kontribusi dengan menguji pengaruh variabel orientasi etika yang menentukan penilaian etis suatu perilaku, yaitu relativisme dan idealisme pada hubungan pengaruh asimetri informasi terhadap senjangan anggaran dengan menggunakan insentif sebagai faktor untuk memicu manajer bawah memanfaatkan asimetri informasi. Hasil penelitian menunjukkan bahwa manajer bawah yang memiliki relativisme atau idealisme baik tinggi ataupun rendah memiliki kecenderungan yang tidak terlalu berbeda dalam membuat senjangan anggaran pada kondisi asimetri informasi. Hal ini menjadi bukti bahwa orientasi etika saja belum tentu 
mempengaruhi keputusan manajer bawah untuk tidak melakukan senjangan anggaran. Tidak terbuktinya faktor orientasi etika untuk memprediksi tindakan yang dilakukan manajer bawah mengindikasikan adanya faktor lain yang dapat mempengaruhi keputusan manajer bawah untuk melakukan suatu tindakan. Faktorlain tersebut kemungkinan besar adalah faktor situasional yang dapat mempengaruhi motivasi manajer bawah sehingga bertindak berbeda dengan pertimbangan moral yang dilakukannya.

\section{Keterbatasan Penelitian}

Penelitian ini memiliki beberapa keterbatasan antara lain:

1. Banyaknya partisipan yang tidak lolos dalam manipulation check. Hal ini mungkin terjadi karena partisipan tidak membaca secara teliti kasus yang diberikan sehingga jawaban dari partisipan tidak dapat diolah.

2. Kasus dalam eksperimen diberikan dalam bentuk ilustrasi yang sederhana sehingga belum mencerminkan secara penuh kasus yang terjadi di lapangan. Hal tersebut karena peneliti menggunakan ilustrasi kasus asimetri informasi tinggi yang tidak memberikan laporan hasil semua tugas produksi di mana hal tersebut tidak mungkin terjadi di lapangan.

3. Penggunaan mahasiswa sebagai sampel dalam penelitian yang mungkin belum terlibat secara langsung dalam proses penyusunan anggaran sehingga memungkinkan terjadinya bias pada hasil penelitian sehingga hasil tidak bisa digeneralisasikan. 
4. Treatment yang diberikan melalui angket mungkin menimbulkan perbedaan persepsi dan pemahaman terhadap maksud treatment sehingga dapat mempengaruhi respon partisipan.

\section{Saran}

Berdasarkan hasil penelitian dan kesimpulan maka saran-saran yang dapat diberikan berkaitan dengan pengaruh asimetri informasi terhadap senjangan anggaran berdasarkan orientasi etika, yaitu:

1. Bagi Perusahaan

a. Perusahaan dapat mengurangi asimetri informasi melalui pengungkapan (disclosure) dalam laporan keuangan. Pengungkapan (disclosure) dilakukan secara akurat, tepat waktu, dan transparan atas semua kinerja pada laporan keuangan. Pengungkapan pada laporan keuangan tersebut harus dicek oleh audit internal perusahaan untuk menilai keakuratan laporan keuangan tersebut. Audit internal lalu akan memberikan semua informasi yang didapat dari laporan keuangan kepada manajer atas.

b. Manajer atas dapat memberikan insentif berupa saham kepada manajer bawah agar manajer bawah merasa memiliki perusahaan sehingga mau memberikan informasi yang dimilikinya.

c. Perusahaan juga harus mempraktikkan budaya etis di perusahaan dengan cara membuat suatu peraturan atau kode etik yang mengatur tindakan-tindakan semua lapisan stakeholder yang ada di perusahaan. Bagi yang melanggar peraturan atau kode etik tersebut diberikan 
hukuman (punishment) yang berat. Atasan hendaknya memberi contoh bagi bawahannya dengan selalu bertindak etis karena tindakan atasan akan mempengaruhi tindakan bawahan.

\section{Bagi Peneliti Selanjutnya}

Penelitian ini diharapkan memberikan ide untuk pengembangan penelitian selanjutnya. Berdasarkan keterbatasan penelitian maka diharapkan penelitian selanjutnya memperhatikan hal-hal berikut ini:

a. Penelitian sebaiknya dilakukan dengan sampel manajer bawah yang sesungguhnya karena mereka terlibat langsung dalam proses penyusunan anggaran.

b. Kasus treatment asimetri informasi dalam instrumen penelitian dapat didesain ulang agar lebih sesuai dengan yang terjadi di lapangan. Misalnya mengganti ilustrasi kasus asimetri informasi tinggi dimana manajer bawah diasumsikan tidak memberikan laporan hasil semua tugas produksi dengan ilustrasi yang lain.

c. Peneliti selanjutnya sebaiknya melaksanakan penelitian eksperimen pada saat mahasiswa tidak memiliki jadwal kuliah yang padat karena mahasiswa cenderung lelah dan jenuh sehingga dapat mempengaruhi minat mahasiswa untuk mengisi angket penelitian.

d. Peneliti selanjutnya sebaiknya menyajikan kasus eksperimen lebih menarik untuk dibaca partisipan untuk memunculkan minat partisipan untuk membaca kasus eksperimen mengingat mahasiswa cenderung 
malas untuk membaca kasus eksperimen dengan seksama sehingga dapat mempengaruhi respon mereka.

e. Penelitian selanjutnya dapat menguji masalah senjangan anggaran dengan memasukkan variabel situasional yang berkaitan dengan etika, misalnya budaya etis organisasi (organizational ethical culture). 


\section{DAFTAR PUSTAKA}

Abdullah, I. A. (2013). "The Influence of Horizontal Equity, Self Efficacy, and Ethical Position On The Creation of Budgetary Slack”. Virginia Commonwealth University: Disertasi.

Agus, Ahyari. (2008). Anggaran Perusahaan. Yogyakarta : BPFE.

Al-Rwita, S. S. (2008). "Budgetary Slack: The Effects of Truth-Inducing Schemes on Slack and Performance”.

Anas, Sudijono. (2011). “Pengantar Statistik Pendidikan”. Jakarta: PT Raja Grfaindo Persada.

Anthony, Robet N dan Govindarajan. (2005). Management Control System. (Alih Bahasa Kurniawan Tjakrawala). Jakarta: Salemba Empat.

Anwar, Sanusi. (2013). Metodologi Penelitian Bisnis. Jakarta: Salemba Empat.

Arfan, Ikhsan. (2008). Metodologi Penelitian Akuntansi Keperilakuan. Yogyakarta: Graha Ilmu.

Arfan, Ikhsan. (2011). Akuntansi Keperilakuan. Jakarta : Salemba Empat.

Brownell, P. J. (1982). "Participation in Budgeting, Locus of Control and Organizational Effectiveness”. The Accounting Review, Vol. 56. Hlm: 844 860.

Chow, C.W, Cooper, J.C. \& Waller, W. S. (1988). "Participative Budgeting: Effects of A Truth-Inducing Pay Scheme and Information Asymmetry on Slack and Performance." The Accounting Review. Vol. 38. No. 1.

Delli, M \& Ertambang, N. (2008). "Influence of Fairness Perception and Trust On Budgetary Slack: Study Experiment On Participation Budgetary Context".

Didit, Herlianto. (2011). Teknik Penyusunan Anggaran Operasional Perusahaan. Yogyakarta: Gosyen Publishing.

Douglas, P.C \& Wier, Benson. (2000). "Integrating Ethical Dimensions into A Modal of Slack Creation”. Journal of Business Ethics, Vol. 28, Hlm. 267277. 
Dunk, S. Alan. (1991). "The Effect of Budget Emphasis and Information Asymmetry on the Relation Between Budgetary Participation and Slack”. The Accounting Review, Vol. 68. No. 2, Hlm. 400-410.

Dunk, S. A \& Perera, H. (1996). "The Incidence of Budgetary Slack: A Field Study Exploration”. Accounting, Auditing \& Accountability Journal, Vol. 10, Hlm. $649-664$.

Efferin, S., Darmadji, S. H., \& Tan, Y. (2008). Metode Penelitian Akuntansi; Mengungkap Fenomena dengan Pendekatan Kuantitatif dan Kualitatif. Yogyakarta: Graha Ilmu.

Elizabeth. V. P. (2014). "Pengaruh Asimetri Informasi dan Locus of Control pada Hubungan Antara Penganggaran Partisipatif dengan Senjangan Anggaran”. E-Jurnal Akuntansi Universitas Udayana. Vol. 6. No. 2. Hlm: 287 - 305.

Falikhatun. (2007). 'Interaksi Informasi Asimetri, Budaya Organisasi, dan Group Cohesiveness dalam Hubungan Antara Partisipasi Penganggaran dan Budgetary Slack.”. Simposium Nasional Akuntansi X.

Faria, J.A \& Silva, S.M.G. (2013). "The Effect of Information Asymmetry on Budget Slack: An Experimental Research”. African Journal of Business Management Vol. 7, Hlm. 1086-1099.

Ferrel, O. C. \& Gresham, L. G. (1985). "A Contingency Framework for Understanding Ethical Decision Making in Marketing”. Journal of Marketing Vol. 49. Hlm: 87 - 96.

Fisher, J., Frederickson, J. R \& Peffer, S. A. (2000). "Budgeting: An Experimental Investigation of Effect of Negotiation". The Accounting Review, Hlm. 93-114.

Forsyth, D. R. (1980). "A Taxonomy of Ethical Ideologies". Journal of Personality and Social Psychology, 39(1), 175-184.

Forsyth, D. R. (1992). "Judging The Morality of Business Practices: The Influence of Personal Moral Philosofies.” Journal of Business Ethics. Hlm: 461-470.

Forsyth, D.R., and Nye, J. L. (1990). "Personal Moral Philosophies and Moral Choice”. Journal of Research in Personality, Vol. 24, No. 4. Hlm: 398-414.

Hadari, Nawawi. (2001). Manajemen Sumber Daya Manusia. Jakarta: Bumi Aksara. 
Hani, T. Handoko. (2000). Manajemen Personalia dan Sumber Daya Manusia. Yogyakarta: BPFE.

Hansen \& Mowen. (2006). Management Accounting. (Alih Bahasa : Dewi Fitriasari \& Deny Arnos). Jakarta : Salemba Empat.

Hamid, Darmadi. (2011). Metode Penelitian Pendidikan. Bandung: Alfabeta.

Harrell. A \& Harrison, P. (1994). "An Incentive to Shirk, Privately-Held Information and Managers Project Evaluation Decisions”. Accounting Organization and Society. Vol. 19. Hlm. 569-577.

Hunt, S.D \& Vittel, S. (1986). “A General Theory of Marketing Ethics”. Journal of Macromarketing. Vol 6. Hlm: 5 - 16.

Imam, Ghozali. (2011). "Aplikasi Analisis Multivariate dengan Program IBM SPSS 19”. Edisi 5. Semarang: Badan Penerbit Universitas Dipenegoro.

Indira, Januarti. (2011). "Analisis Pengaruh Pengalaman Auditor, Komitmen Profesional, Orientasi Etis dan Nilai Etika Organisasi terhadap Persepsi dan Pertimbangan Etis”. Simposium Nasional Akuntansi XIV Aceh.

Kren, Leslie. (1992). "Budgetary Participation and Managerial Performance: The Impact of Information and Environment Volatility". The Accounting Review, Hlm. 511-528.

Kren, Leslie. (2003). "Effect of Uncertainty, Participation, and Control System Monitoring on The Propensity to Create Budget Slack and Actual Budget Slack Created". Advances in Management Accounting, Vol. 11, Hlm. 143167.

Kyj, Larissa \& Parker, R. J. (2008). "Antecedents of Budget Participation: Leadership Style, Information Asymmetry, and Evaluative Use of Budget”. ABACUS, Vol. 44, No. 4.

Kung, Fan-Hua \& Huang, Cheng-Li. (2010). “Auditors' Moral Philosophies and Ethical Beliefs". Management Decision. Vol. 51, Issue 4.

Lau, C. M \& Egg;eton, I. R. C. (2003). “The Influence of Information Asymmetry and Budget Emphasis on The Relationship Between Participation and Slack”. Accounting and Behavioural Research, Vol. 33, No. 2, Hlm. 91-104. 
Lavarda, C. E. F \& Almeida, D. M. (2013). "Budget Participation and Information Asymmetry: A Study in A Multinational Company”. Brazilian Business Review, Vol. 10, No. 2, Hlm. 72-94.

Lukka, K. (1988). "Budgetary Biasing In Organizations: Theoretical Framework And Empirical Evidence”. Accounting, Organization And Society, Hlm: 281-301.

Luthans, F. 1998. Organizational Behavior. Eighth Edition. Boston: McGrawHill, Inc.

Maiga, A. S \& Jacobs, F. A. (2008). "The Moderating Effect of Manager's Ethical Judgment On The Relationship Between Budget Participation And Budget Slack”. Advances in Accounting Vol. 23, Hlm. 113-145.

Munandar, M. (1985). Budgeting: Perencanaan Kerja, Pengkoordinasian Kerja, Pengawasan Kerja, Edisi 1. Yogyakarta: BPFE.

Muthmainah, S. (2006). "Studi Tentang Perbedaan Evaluasi Etis, Intense Etis, dan Orientasi Etis Dilihat dari Gender dan Disiplin Ilmu: Potensi Rekruitmen Staf Profesional Pada Kantor Akuntan Publik". Jurnal Seminar Nasional Akuntansi 9. Padang.

Nafarin, M. (2007). Penganggaran Perusahaan, Edisi 3. Jakarta: Salemba Empat.

Onsi, M. (1973). "Factor Analysis of Behavioral Variables Affecting Budgetary Slack”. The Accounting Review, Vol. 48, No. 3, Hlm: 535-548.

Ponemon. (1991). "The Influence of Ethical Reasoning on Auditors' Perceptions of Management's Integrity and Competence”. Advances in Accounting. Vol. 11. Hlm: $1-29$.

Pope, P. F. (1984). "Informational Asymmetry in Participative Budgeting: A Bargaining Approach”. Journal of Business Finance and Accounting, Hlm. 41-59.

Schiff, M., \& Lewin, A. Y. (1970). "The Impact of People On Budgets". The Accounting Review. Hlm: 259-268.

Schlenker, B. R. \& Forsyth, D. R. (1977). "On The Ethics of Pychological Research”. Journal of Experimental Social Psychology. Vol. 13. Hlm: 369 $-396$. 
Shaub, M. K., Finn, D. W., \& Munter, P. (1993). "The Effects Of Auditors' Ethical Orientation On Commitment And Ethical Sensitivity”. Behavioral Research in Accounting. Vol. 5. Hlm: 145-169.

Shim, J. K \& Siegel, J. G. (2001). Penganggaran. (Alih Bahasa: Julius Mulyadi \& Neneng Natalia). Jakarta : Erlangga.

Shields, M. D., and Young, S. M. (1993). "Antecedents And Consequences Of Participative Budgeting: Evidence On The Effects Of Asymmetrical Information". Journal of Management Accounting Research. Hlm: 265-280.

Simamora, H. (1995). Manajemen Sumber Daya Manusia. Yogyakarta: Penerbitan STIE YKPN.

Stevens, D.E. (2002). "The Effects of Reputation and Ethics on Budgetary Slack". Journal of Management Accounting Research. Vol. 14, Hlm. 153.

Sugiyono.(2007). Statistika untuk Penelitian. Yogyakarta : BPFE.

Sugiyono. (2010). Metode Penelitian Kuantitatif Kualitatif \& RND. Bandung: Alfabeta.

Sutedja. (2004). "Pengungkapan (Disclosure) Laporan Keuangan Sebagai Upaya Mengatasi Asimetri Informasi”. TEMA. Vol. 5, No. 5.

Suwanda. (2011). Desain Eksperimen untuk Penelitian Ilmiah. Bandung: Alfabeta.

Tri. S. N \& Slamet, S. (2004). "Pengaruh Reputasi, Etika, dan Self Esteem Pada Budgeting Slack”. Simposium Nasional Akuntansi X.

Tsalikis, J \& Fritzsche, D. J. (1989). "Business Ethics: A Literature Review With A Focus On Marketing Ethics”. Journal of Business Ethics. Vol. 8. No. 9. Hlm: $695-743$.

Waller, W. (1988). "Slack in Participative Budgeting: The Joint Effect of A TruthInducing Scheme and Risk Preferences". Accounting, Organizations and Society. Vol 13, No. 1, Hlm:87 - 98.

Welsch, G. A., Hilton, R. W. \& Gordon, P. N. (2000). Budgeting: Planning and Profit Control. (Alih Bahasa : Purwatiningsih \& Maudy Warouw). Jakarta: Salemba Empat.

Yamin, S. \& Kurniawan, H. (2009). SPSS Complete; Teknik Analisis Statistik Terlengkap dengan Software SPSS. Jakarta: Salemba Infotek. 
Young, S. Mark. (1985). "Participative Budgeting: The Effect of Risk Aversion and Asymmetric Information on Budgetary Slack”. Journal of Accounting Research, Vol. 32, No. 2, Hlm. 829-842.

Yusuf, Wibisono. (2005). Metode Statistik. Yogyakarta: Gadjah Mada University Press. 


\section{LAMPIRAN \\ 1}




\section{PENGANTAR}

\section{Dengan hormat,}

Melalui kesempatan ini, perkenankanlah saya memohon kesediaan Saudara untuk menjadi partisipan untuk mengikuti eksperimen penelitian.Penelitian berjudul "Pengaruh Asimetri Informasi terhadap Senjangan Angggaran pada Penganggaran Partisipatif dengan Orientasi Etika Sebagai Variabel Moderating" ini bertujuan untuk mengetahui pengaruh asimetri informasi dan terhadap kecenderungan senjangan anggaran yang dilakukan manajer bawah berdasarkan orientasi etikanya. Data yang diperoleh akan digunakan sebagai bahan skripsi peneliti. Beberapa hal yang perlu diperhatikan dalam eksperimen antara lain sebagai berikut :

1. Dalam eksperimen ini, peserta diharapkan dapat mengerjakan semua tugas yang telah diberikan secara independen dan sesuai dengan pendapat saudara.

2. Peserta dimohon bersungguh-sungguh dan teliti dalam memahami dan mengerjakan tugas yang dikerjakan. Kesungguhan Anda akan sangat membantu kelancaran dan keberhasilan eksperimen ini.

Terima kasih atas perhatian dan partisipasi Anda.

Hormat saya,

Ria Afriani $\mathrm{H}$ 


\section{PROSEDUR EKSPERIMEN}

11. Membagi angket penelitian kepada partisipan berdasarkan kelompok kasus asimetri informasi.

12. Partisipan mengisi data demografis seperti, jenis kelamin, umur, angkatan, mata kuliah yang diambil, dan IPK.

13. Penjelasan mengenai penelitian yang akan dilakukan.

14. Melakukan tugas produksi 1 dalam jangka waktu 2 menit.

15. Melakukan tugas produksi 2 dalam jangka waktu 2 menit.

16. Melakukan tugas produksi 3 dalam jangka waktu 2 menit.

17. Partisipan diminta mengisi hasil tugas produksi 1, 2, dan 3 pada angket

18. Treatment pada masing-masing kelompok perlakuan.

19. Partisipan diminta menentukan target dalam menyelesaikan tugas produksi selanjutnya yang akan diajukan.

20. Pengisian manipulation check.

21. Pengisian kuesioner orientasi etika. 


\section{DATA DEMOGRAFIS}

\begin{tabular}{|c|c|c|c|}
\hline Nama & : & 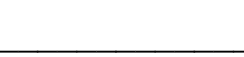 & (waj \\
\hline NIM & . & & \\
\hline Prodi & $:$ & & \\
\hline E-mail & $:$ & & \\
\hline Umur & $: \square 18$ tahun & $\square 20$ tahun & $\square 22$ tahun \\
\hline & $\square 19$ tahun & $\square 21$ tahun & $\square>22$ tahun \\
\hline Angkatan & $: \square 2010$ & $\square 2011$ & \\
\hline Kelas & $: \square \mathrm{A}$ & $\square \mathrm{B}$ & \\
\hline Jenis Kelamin & $: \square$ Perempuan & $\square$ Laki-Laki & \\
\hline Mata Kuliah & : $\square$ Akuntansi $\mathrm{I}$ & men & \\
\hline & $\square$ Penganggar & & \\
\hline & $\square$ Sistem Pen & ian Manajemen & \\
\hline IPK & $: \square<3.00$ & $\square 3.26-3.50$ & \\
\hline & $\square 3.00-3.25$ & $\square>3.51$ & \\
\hline
\end{tabular}




\title{
PRODUKSI PESAWAT TERBANG PT MAJU JAYA
}

\author{
Anda adalah manajer bawah bagian produksi PT MAJU JAYA, \\ perusahaan yang memproduksi pesawat terbang kertas, sedangkan peneliti \\ berperan sebagai atasan Anda. Sebagai manajer bawah bagian produksi, Anda \\ akan terlibat dalam proses penyusunan anggaran produksi perusahaan dan \\ bertugas untuk menentukan target produksi untuk tahun mendatang.
}

Untuk menentukan target produksi, Anda harus mengetahui kemampuan kinerja Anda terlebih dahulu. Oleh karena itu, Anda akan diminta melakukan tugas produksi selama 3 kali untuk mengukur kemampuan kinerja Anda. Setiap tugas produksi diberi waktu selama 2 menit.

Hasil tugas produksi 1 dan tugas produksi 2 diasumsikan sebagai hasil pengalaman Anda dalam memproduksi pesawat terbang kertas di masa lalu. Hasil tugas produksi 3 diasumsikan sebagai estimasi terbaik Anda dalam memproduksi pesawat terbang untuk tahun mendatang.

Setelah Anda melakukan tugas produksi, Anda diminta menetukan target produksi pesawat terbang selama 2 menit mendatang. 
Untuk memotivasi Anda, atasan Anda akan memberikan kompensasi agar Anda dapat melampaui target yang Anda tentukan. Atasan Anda akan memberikan kompensasi dengan skema berikut:

Total kompensasi yang diperoleh $=10.000+[100 \times($ Jumlah produksi yang sesungguhnya - Target produksi)]

Keterangan :

$10.000=$ Gaji tetap yang diterima manajer bawah

$100 \quad=$ Bonus tiap unit

*Dalam hal ini hasil tugas produksi 3 diasumsikan sebagai jumlah produksi yang sesungguhnya.

*Besarnya bonus tiap unit tergantung pada selisih antara jumlah produksi yang sesungguhnya dengan targer produksi dikali 100.

Jika Anda tidak berhasil mencapai target produksi, Anda hanya mendapatkan gaji tetap sebagai manajer bawah, yaitu 10.000. Jika Anda berhasil melampaui target produksi maka Anda akan memperoleh kompensasi sebesar gaji tetap Anda ditambah dengan selisih jumlah pesawat terbang kertas yang Anda hasilkan yang dikurangi dengan target produksi yang kemudian dikalikan dengan insentif per unit. Insentif yang Anda terima akan semakin besar jika selisih jumlah pesawat terbang kertas yang dihasilkan dengan target produksi semakin besar. 
Jika target Anda dalam memproduksi pesawat terbang kertas sebanyak 7 buah dan ternyata Anda berhasil menghasilkan 9 buah pesawat terbang kertas pada tugas produksi 3 maka Anda akan mendapatkan kompensasi sebagai berikut :

$10.000+[100 \times(9-7)]=10.200$

Jadi, Anda akan memperoleh kompensasi sebesar 10.200.

\section{TUGAS PRODUKSI 1}

Sekarang Anda diminta untuk melakukan tugas produksi 1 dengan membuat pesawat terbang kertas menggunakan kertas yang sudah disediakan. Waktu pengerjaan selama 2 menit. Anda tidak boleh mulai mengerjakan sebelum diperintah peneliti. Setelah selesai membuat pesawat terbang kertas, Anda diminta untuk menuliskan jumlah pesawat terbang yang berhasil Anda buat. Selamat mengerjakan.

Tulis jumlah pesawat terbang kertas yang berhasil Anda buat.

Jumlah pesawat terbang selama 2 menit $=$ buah 


\title{
TUGAS PRODUKSI 2
}

\begin{abstract}
Sekarang Anda diminta untuk melakukan tugas produksi 2 dengan membuat pesawat terbang kertas menggunakan kertas yang sudah disediakan. Waktu pengerjaan selama 2 menit. Anda tidak boleh mulai mengerjakan sebelum diperintah peneliti.Setelah selesai membuat pesawat terbang kertas, Anda diminta untuk menuliskan jumlah pesawat terbang yang berhasil Anda buat. Selamat mengerjakan.
\end{abstract}

Tulis jumlah pesawat terbang kertas yang berhasil Anda buat.

Jumlah pesawat terbang selama 2 menit $=$ buah 


\section{TUGAS PRODUKSI 3}

Sekarang Anda diminta untuk melakukan tugas produksi 3 dengan membuat pesawat terbang kertas menggunakan kertas yang sudah disediakan. Waktu pengerjaan selama 2 menit. Anda tidak boleh mulai mengerjakan sebelum diperintah peneliti. Setelah selesai membuat pesawat terbang kertas, Anda diminta untuk menuliskan jumlah pesawat terbang kertas yang berhasil Anda buat. Selamat mengerjakan.

Tulis jumlah pesawat terbang kertas yang berhasil Anda buat.

Jumlah pesawat terbang selama 2 menit $=$ buah

Setelah melakukan tugas produksi, hitung expected performance Anda dengan rumus :

$$
\begin{aligned}
\text { Expected Performance } & =\frac{\text { Hasil Produksi } 1+\text { Hasil Produksi } 2}{2} . \\
\text { Expected Performance } & =\frac{\ldots \ldots \ldots \ldots \ldots \ldots \ldots \ldots \ldots . .+\cdots \ldots \ldots \ldots \ldots \ldots \ldots \ldots \ldots \ldots . . \ldots \ldots \ldots \ldots \ldots \ldots \ldots \ldots \ldots \ldots}{2} \\
& =
\end{aligned}
$$




\section{KELOMPOK PERLAKUAN 1}

(TIDAK ADA ASIMETRI INFORMASI)

Anda sebagai manajer bawah PT MAJU JAYA DIMINTA ATASAN ANDA untuk MENYERAHKAN SEMUA LAPORAN HASIL TUGAS PRODUKSI 1, TUGAS PRODUKSI 2, DAN TUGAS PRODUKSI 3 yang telah Anda lakukan. Hal tersebut membuat ATASAN ANDA DAPAT MENGETAHUI KEMAMPUAN KINERJA ANDA dalam menyelesaikan tugas produksi 1, 2, dan 3. ATASAN ANDA AKAN TAHU BERAPA JUMLAH PESAWAT TERBANG YANG DAPAT ANDA HASILKAN SESUNGGUHNYA berdasarkan dari hasil laporan yang Anda berikan kepada atasan Anda. Jika atasan meminta Anda untuk menentukan target produksi selanjutnya, ATASAN ANDA AKAN DAPAT MENGEVALUASI SECARA AKURAT jika Anda menentukan target produksi di bawah kemampuan kinerja terbaik Anda. Hal tersebut membuat Anda tidak memiliki kesempatan untuk merendahkan target produksi di bawah kemampuan kinerja Anda.

Berdasarkan dari uraian di atas, Anda diminta untuk menentukan target produksi dalam menyelesaikan pesawat terbang kertas selama 2 menit. Penentuan target harap memperhatikan :

1. Kemampuan Anda berdasarkan pengerjaan tugas produksi

2. Skema insentif yang ingin diperoleh

3. Kondisi asimetri informasi

Target produksi yang diajukan dalam waktu 2 menit = buah 


\section{MANIPULATION CHECK}

Setelah Anda menentukan target produksi, Anda diminta mengisi jawaban dengan memberikan tanda $(\sqrt{ })$ pada kolom Benar atau Salah. Pernyataanpernyataan dibawah ini berkaitan dengan kasus yang telah Anda baca.

\begin{tabular}{|c|c|c|c|}
\hline No. & Pernyataan & Benar & Salah \\
\hline 1. & $\begin{array}{l}\text { Berdasarkan kasus yang telah Anda baca, Anda diminta } \\
\text { untuk menentukan target produksi pesawat terbang kertas } \\
\text { berdasarkan kemampuan kinerja Anda dalam } \\
\text { menyelesaikan tugas produksi, insentif yang ingin Anda } \\
\text { dapatkan, dan kondisi asimetri informasi. }\end{array}$ & & \\
\hline 2. & $\begin{array}{l}\text { Atasan Anda akan memberikan insentif jika Anda berhasil } \\
\text { melampaui target produksi Anda. }\end{array}$ & & \\
\hline 3. & $\begin{array}{l}\text { Jika Anda menentukan target produksi } 6 \text { dan ternyata Anda } \\
\text { dapat membuat pesawat terbang kertas sebanyak } 7 \text { buah, } \\
\text { kompensasi yang Anda dapatkan adalah } 10.000+[100 \times(7 \\
-6)]=10.100 \text {. }\end{array}$ & & \\
\hline 4. & $\begin{array}{l}\text { Berdasarkan kasus yang Anda baca, Anda diminta } \\
\text { menyerahkan semua laporan hasil tugas produksi kepada } \\
\text { atasan Anda. }\end{array}$ & & \\
\hline 5. & $\begin{array}{l}\text { Kompensasi yang akan saya terima akan semakin besar } \\
\text { jika selisih jumlah pesawat terbang yang dihasilkan dengan } \\
\text { targer produksi yang diajukan semakin besar. }\end{array}$ & & \\
\hline 6. & $\begin{array}{l}\text { Selama eksperimen,atasan dapat mengevaluasi secara } \\
\text { akurat jika saya menentukan anggaran lebih rendah dari } \\
\text { kemampuan kinerja saya. }\end{array}$ & & \\
\hline 7. & $\begin{array}{l}\text { Selama eksperimen, manajer atas dapat mengetahui } \\
\text { kemampuan kinerja saya. }\end{array}$ & & \\
\hline 8. & $\begin{array}{l}\text { Atasan saya dapat mengetahui kemampuan kinerja saya } \\
\text { sehingga saya tidak memiliki kesempatan untuk } \\
\text { merendahkan kemampuan kinerja saya dalam menentukan } \\
\text { target produksi. }\end{array}$ & & \\
\hline
\end{tabular}




\section{KELOMPOK PERLAKUAN 2}

\section{(ASIMETRI INFORMASI RENDAH)}

Anda sebagai manajer bawah PT MAJU JAYA hanya MENYERAHKAN LAPORAN HASIL TUGAS PRODUKSI 1. Hal tersebut membuat ATASAN ANDA KURANG MENGETAHUI KEMAMPUAN KINERJA ANDA karena hasil produksi 2 dan 3 tidak Anda serahkan. Atasan Anda hanya DAPAT MEMPERKIRAKAN KEMAMPUAN KINERJA ANDA MELALUI LAPORAN HASIL PRODUKSI 1 yang Anda berikan. PERKIRAAN ATASAN ANDA TERHADAP KEMAMPUAN KINERJA ANDA DAPAT MELESET karena atasan Anda tidak menerima laporan hasil produksi 2 dan 3. Ketika atasan Anda meminta Anda menetukan target produksi selanjutnya, ADA KEMUNGKINAN ATASAN ANDA AKAN TAHU BISA JUGA TIDAK JIKA ANDA MENETAPKAN TARGET DIBAWAH KEMAMPUAN KINERJA PRODUKSI ANDA. Dengan begitu, Anda hanya memiliki kesempatan kecil untuk bisa merendahkan target produksi Anda di bawah kemampuan kinerja Anda.

Berdasarkan dari uraian di atas, Anda diminta untuk menentukan target produksi dalam menyelesaikan pesawat terbang kertas selama 2 menit. Penentuan target harap memperhatikan :

1. Kemampuan Anda berdasarkan pengerjaan tugas produksi

2. Skema insentif yang ingin diperoleh

3. Kondisi asimetri informasi

Target produksi yang diajukan dalam waktu 2 menit = buah 


\section{MANIPULATION CHECK}

Setelah Anda menentukan target produksi, Anda diminta mengisi jawaban dengan memberikan tanda $(\sqrt{ })$ pada kolom Benar atau Salah. Pernyataanpernyataan dibawah ini berkaitan dengan kasus yang telah Anda baca.

\begin{tabular}{|c|c|c|c|}
\hline No. & Pernyataan & Benar & Salah \\
\hline 1. & $\begin{array}{l}\text { Berdasarkan kasus yang telah Anda baca, Anda } \\
\text { diminta untuk menentukan target produksi pesawat } \\
\text { terbang kertas berdasarkan kemampuan kinerja } \\
\text { Anda dalam menyelesaikan tugas produksi. }\end{array}$ & & \\
\hline 2. & $\begin{array}{l}\text { Atasan Anda akan memberikan insentif jika Anda } \\
\text { berhasil melampaui target produksi Anda. }\end{array}$ & & \\
\hline 3. & $\begin{array}{l}\text { Jika Anda menentukan target produksi } 6 \text { dan } \\
\text { ternyata Anda dapat membuat pesawat terbang } \\
\text { kertas sebanyak } 7 \text { buah, kompensasi yang Anda } \\
\text { dapatkan adalah } 10.000+[100 \times(7-6)]=10.100 \text {. }\end{array}$ & & \\
\hline 4. & $\begin{array}{l}\text { Berdasarkan kasus yang Anda baca, Anda } \\
\text { menyerahkan laporan hasil produksi } 1 \text { kepada } \\
\text { atasan Anda. }\end{array}$ & & \\
\hline 5. & $\begin{array}{l}\text { Kompensasi yang akan saya terima akan semakin } \\
\text { besar jika selisih jumlah pesawat terbang yang } \\
\text { dihasilkan dengan targer produksi yang diajukan } \\
\text { semakin besar. }\end{array}$ & & \\
\hline 6. & $\begin{array}{l}\text { Selama eksperimen,atasan saya bisa tahu bisa juga } \\
\text { tidak jika saya menetapkan target produksi di } \\
\text { bawah kemampuan kinerja. }\end{array}$ & & \\
\hline 7. & $\begin{array}{l}\text { Selama eksperimen, manajer atas kurang } \\
\text { mengetahui kemampuan kinerja saya. }\end{array}$ & & \\
\hline 8. & $\begin{array}{l}\text { Atasan saya kurang mengetahui kemampuan kinerja } \\
\text { saya sehingga saya memiliki sedikit kesempatan } \\
\text { untuk merendahkan kemampuan kinerja saya dalam } \\
\text { menentukan target produksi. }\end{array}$ & & \\
\hline
\end{tabular}




\section{KELOMPOK PERLAKUAN 3}

\section{(ASIMETRI INFORMASI TINGGI)}

Anda sebagai manajer bawah PT MAJU JAYA TIDAK MENYERAHKAN LAPORAN HASIL TUGAS PRODUKSI 1, 2, dan 3. Hal tersebut membuat ATASAN ANDA TIDAK MENGETAHUI KEMAMPUAN KINERJA ANDA. ATASAN ANDA TIDAK BISA MEMPERKIRAKAN BERAPA JUMLAH PESAWAT TERBANG YANG DAPAT ANDA HASILKAN SESUNGGUHNYA. Ketika atasan meminta Anda untuk menentukan target tugas produksi selanjutnya, ATASAN ANDA TIDAK DAPAT MENGEVALUASI SECARA AKURAT jika Anda merendahkan target produksi di bawah kemampuan kinerja Anda. Hal tersebut membuat Anda memiliki kesempatan besar untuk merendahkan target produksi Anda di bawah kemampuan kinerja Anda.

Berdasarkan dari uraian di atas, Anda diminta untuk menentukan target produksi dalam menyelesaikan pesawat terbang kertas selama 2 menit. Penentuan target harap memperhatikan :

1. Kemampuan Anda berdasarkan pengerjaan tugas produksi

2. Skema insentif yang ingin diperoleh

3. Kondisi asimetri informasi tinggi

Target produksi yang diajukan dalam waktu 2 menit = buah 


\title{
MANIPULATION CHECK
}

\begin{abstract}
Setelah Anda menentukan target produksi, Anda diminta mengisi jawaban dengan memberikan tanda $(\sqrt{ })$ pada kolom Benar atau Salah. Pernyataanpernyataan dibawah ini berkaitan dengan kasus yang telah Anda baca.
\end{abstract}

\begin{tabular}{|c|c|c|c|}
\hline No. & Pernyataan & Benar & Salah \\
\hline 1. & $\begin{array}{l}\text { Berdasarkan kasus yang telah Anda baca, Anda diminta } \\
\text { untuk menentukan target produksi pesawat terbang kertas } \\
\text { berdasarkan kemampuan kinerja Anda dalam } \\
\text { menyelesaikan tugas produksi. }\end{array}$ & & \\
\hline 2. & $\begin{array}{l}\text { Atasan Anda akan memberikan insentif jika Anda berhasil } \\
\text { melampaui target produksi Anda. }\end{array}$ & & \\
\hline 3. & $\begin{array}{l}\text { Jika Anda menentukan target produksi } 6 \text { dan ternyata Anda } \\
\text { dapat membuat pesawat terbang kertas sebanyak } 7 \text { buah, } \\
\text { kompensasi yang Anda dapatkan adalah } 10.000+[100 \times(7 \\
-6)]=10.100 \text {. }\end{array}$ & & \\
\hline 4. & $\begin{array}{l}\text { Berdasarkan kasus yang Anda baca, Anda tidak } \\
\text { menyerahkan semua laporan hasil tugas produksi kepada } \\
\text { atasan Anda. }\end{array}$ & & \\
\hline 5. & $\begin{array}{l}\text { Kompensasi yang akan saya terima akan semakin besar } \\
\text { jika selisih jumlah pesawat terbang yang dihasilkan dengan } \\
\text { targer produksi yang diajukan semakin besar. }\end{array}$ & & \\
\hline 6. & $\begin{array}{l}\text { Selama eksperimen,atasan tidak dapat mengevaluasi secara } \\
\text { akurat jika saya menentukan anggaran lebih rendah dari } \\
\text { kemampuan kinerja saya. }\end{array}$ & & \\
\hline 7. & $\begin{array}{l}\text { Selama eksperimen, manajer atas tidak tahu kemampuan } \\
\text { kinerja saya. }\end{array}$ & & \\
\hline 8. & $\begin{array}{l}\text { Atasan saya tidak mengetahui kemampuan kinerja saya } \\
\text { sehingga saya memiliki kesempatan besar untuk } \\
\text { merendahkan kemampuan kinerja saya dalam menentukan } \\
\text { target produksi. }\end{array}$ & & \\
\hline
\end{tabular}


Kuesioner di bawah ini merupakan kuesioner untuk mengukur idealisme. Mohon mengisi kolom jawaban yang sudah disediakan berdasarkan pertanyaan yang diberikan dengan menggunakan tanda $(\sqrt{ })$.Setiap jawaban merupakan pendapat Saudara, tidak ada jawaban yang benar dan salah.

$$
\begin{array}{llll}
1 & =\text { Sangat Tidak Setuju } & 4 & =\text { Setuju } \\
2 & =\text { Tidak Setuju } & 5 & =\text { Sangat Setuju } \\
3 & =\text { Netral }
\end{array}
$$

\begin{tabular}{|c|c|c|c|c|c|c|}
\hline No. & Keterangan & 1 & 2 & 3 & 4 & 5 \\
\hline 1. & $\begin{array}{l}\text { Seseorang harus memastikan bahwa } \\
\text { tindakan yang dilakukannya tidak pernah } \\
\text { secara sengaja merugikan pihak lain, } \\
\text { dalam tingkat sekecil apapun. }\end{array}$ & & & & & \\
\hline 2. & $\begin{array}{l}\text { Tindakan yang dapat merugikan pihak } \\
\text { lain tidak dapat ditoleransi, sekecil } \\
\text { apapun tindakan tersebut. }\end{array}$ & & & & & \\
\hline 3. & $\begin{array}{l}\text { Melakukan tindakan yang dapat } \\
\text { merugikan pihak lain adalah tindakan } \\
\text { yang salah, walaupun tindakan tersebut } \\
\text { menguntungkan. }\end{array}$ & & & & & \\
\hline 4. & $\begin{array}{l}\text { Seseorang tidak boleh menyakiti dan } \\
\text { merugikan pihak lain secara fisik } \\
\text { maupun psikologis. }\end{array}$ & & & & & \\
\hline 5. & $\begin{array}{l}\text { Seseorang tidak boleh melakukan } \\
\text { tindakan yang dapat mengancam } \\
\text { martabat dan kesejahteraan pihak lain. }\end{array}$ & & & & & \\
\hline 6. & $\begin{array}{l}\text { Jika suatu tindakan dapat merugikan } \\
\text { pihak yang tidak bersalah maka tindakan } \\
\text { tersebut tidak boleh dilakukan. }\end{array}$ & & & & & \\
\hline
\end{tabular}




\begin{tabular}{|c|c|}
\hline 7. & $\begin{array}{l}\text { Memutuskan untuk melakukan atau tidak } \\
\text { melakukan suatu tindakan dengan } \\
\text { menyeimbangkan dampak positif dan } \\
\text { negatif dari tindakan tersebut adalah } \\
\text { termasuk perbuatan tidak bermoral. }\end{array}$ \\
\hline 8. & $\begin{array}{l}\text { Martabat dan kesejahteraan pihak lain } \\
\text { harus menjadi perhatian utama dalam } \\
\text { suatu masyarakat. }\end{array}$ \\
\hline 9. & $\begin{array}{l}\text { Mengorbankan kesejahteraan pihak lain } \\
\text { adalah hal yang seharusnya tidak } \\
\text { dilakukan. }\end{array}$ \\
\hline 10. & $\begin{array}{l}\text { Tindakan bermoral adalah tindakan yang } \\
\text { sesuai dengan tindakan-tindakan yang } \\
\text { sifatnya ideal/sempurna di mana tidak } \\
\text { ada pihak yang dirugikan dan sesuai } \\
\text { dengan nilai norma. }\end{array}$ \\
\hline
\end{tabular}

Kuesioner di bawah ini merupakan kuesioner untuk mengukur relativisme.Mohon mengisi kolom jawaban yang sudah disediakan berdasarkan pertanyaan yang diberikan dengan menggunakan tanda $(\sqrt{ })$.Setiap jawaban merupakan pendapat Saudara, tidak ada jawaban yang benar dan salah.

$$
\begin{array}{llll}
1 & =\text { Sangat Tidak Setuju } & 4 & =\text { Setuju } \\
2 & =\text { Tidak Setuju } & 5 & =\text { Sangat Setuju } \\
3 & =\text { Netral }
\end{array}
$$

\begin{tabular}{|l|l|l|l|l|l|l|}
\hline No. & \multicolumn{1}{|c|}{ Keterangan } & 1 & 2 & 3 & 4 & 5 \\
\hline 1. & $\begin{array}{l}\text { Tidak ada prinsip etika yang begitu } \\
\text { penting untuk dijadikan bagian dari } \\
\text { kode etik/peraturan apapun. }\end{array}$ & & & & & \\
\hline
\end{tabular}




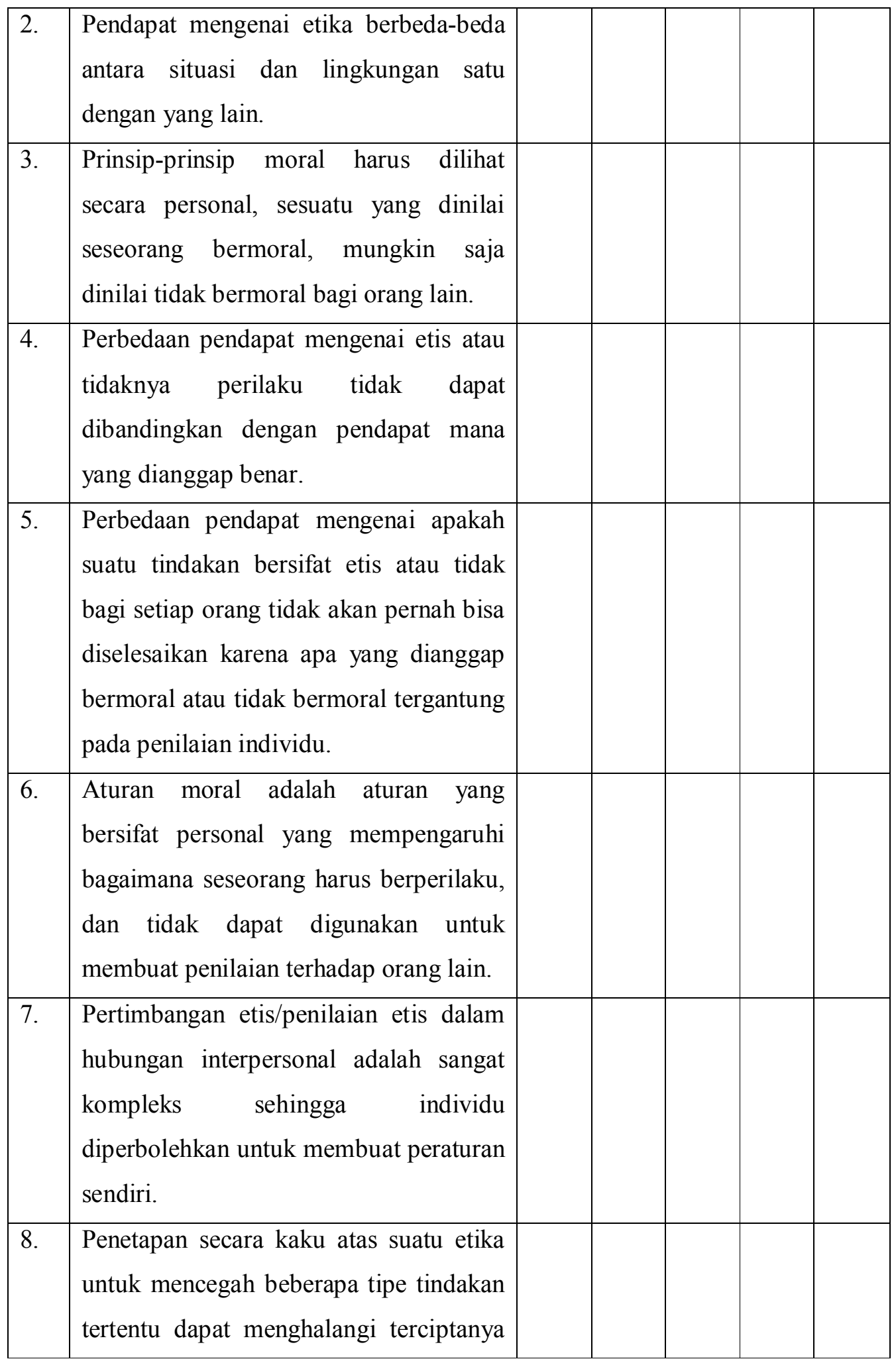




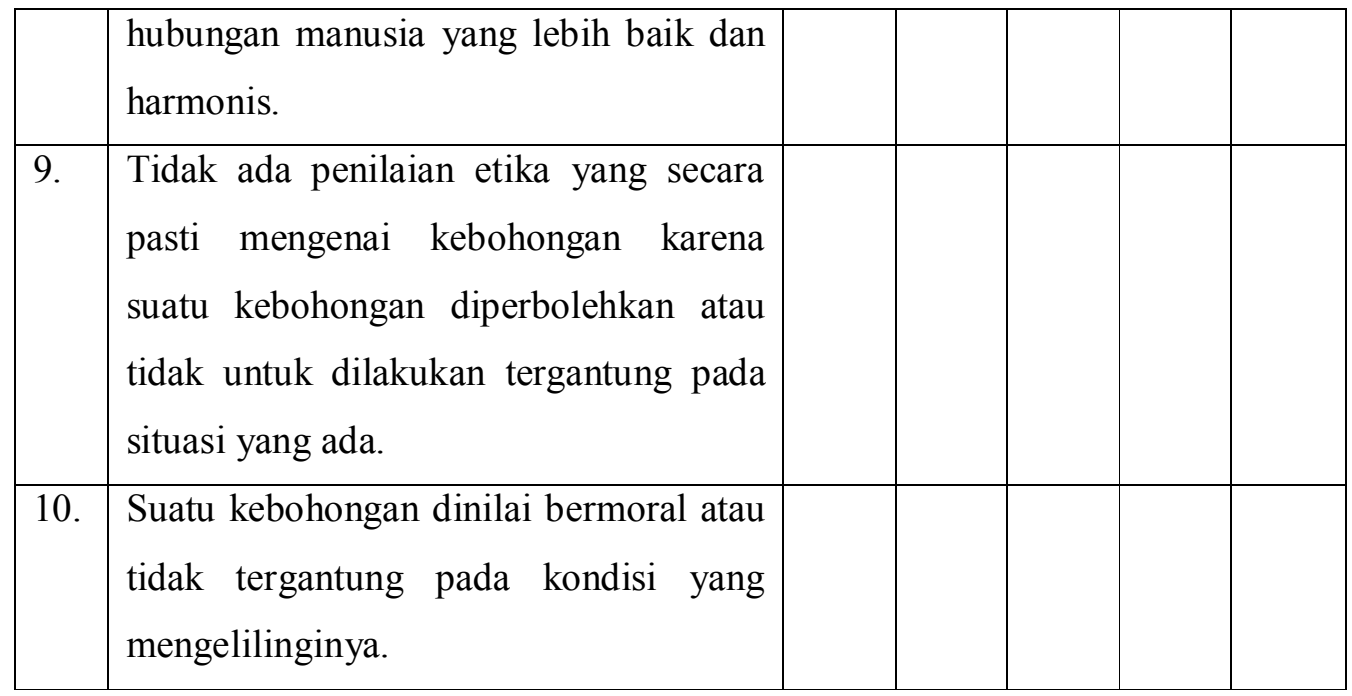




\section{LAMPIRAN}

2 
Tabel 1. Diskripsi Data Subjek Instrumen Kasus

\begin{tabular}{|c|c|c|c|c|c|c|c|c|c|c|c|c|c|c|c|}
\hline No & Umur & $\begin{array}{c}\text { Jenis } \\
\text { Kelamin }\end{array}$ & Angkatan & IPK & Mata & $\begin{array}{l}\text { Luliah yang } \\
\text { Lulus }\end{array}$ & dah & & duk & & $\begin{array}{l}\text { Exp } \\
\text { Perf. }\end{array}$ & Target & Slack & Kompensasi & Kasus \\
\hline 1 & 21 & $\mathrm{P}$ & 2011 & $3,26-3,50$ & Akmen & Anggaran & SPM & 6 & 6 & 7 & 6 & 6 & 0.16667 & 10100 & NONE \\
\hline 2 & 20 & $\mathrm{P}$ & 2011 & $>3,51$ & Akmen & Anggaran & SPM & 4 & 5 & 6 & 4.5 & 5 & 0.22222 & 10100 & NONE \\
\hline 3 & 20 & $\mathrm{P}$ & 2011 & $3,00-3,25$ & Akmen & Anggaran & SPM & 5 & 5 & 8 & 5 & 4 & 0.8 & 10400 & NONE \\
\hline 4 & 21 & $\mathrm{P}$ & 2011 & $>3,51$ & Akmen & Anggaran & SPM & 5 & 7 & 8 & 6 & 7 & 0.16667 & 10100 & NONE \\
\hline 5 & 20 & $\mathrm{P}$ & 2011 & $3,26-3,50$ & Akmen & Anggaran & SPM & 6 & 7 & 8 & 6.5 & 8 & 0 & 10000 & NONE \\
\hline 6 & 21 & $\mathrm{~L}$ & 2011 & $3,00-3,25$ & Akmen & Anggaran & SPM & 8 & 10 & 10 & 9 & 9 & 0.11111 & 10100 & NONE \\
\hline 7 & 20 & $P$ & 2011 & $>3,51$ & Akmen & Anggaran & SPM & 3 & 5 & 6 & 4 & 5 & 0.25 & 10100 & NONE \\
\hline 8 & 20 & $\mathrm{P}$ & 2011 & $>3,51$ & Akmen & Anggaran & SPM & 9 & 10 & 12 & 9.5 & 11 & 0.10526 & 10100 & NONE \\
\hline 9 & 21 & $\mathrm{~L}$ & 2011 & $3,00-3,25$ & Akmen & Anggaran & SPM & 2 & 4 & 5 & 3 & 5 & 0 & 10000 & NONE \\
\hline 10 & 20 & $\mathrm{P}$ & 2011 & $3,26-3,50$ & Akmen & Anggaran & SPM & 4 & 5 & 5 & 4.5 & 5 & 0 & 10000 & NONE \\
\hline 11 & 20 & $\mathrm{P}$ & 2011 & $3,26-3,50$ & Akmen & Anggaran & SPM & 2 & 3 & 3 & 2.5 & 2 & 0.4 & 10100 & NONE \\
\hline 12 & 22 & $\mathrm{P}$ & 2011 & $3,26-3,50$ & Akmen & Anggaran & SPM & 6 & 6 & 9 & 6 & 6 & 0.5 & 10300 & NONE \\
\hline 13 & 20 & $\mathrm{P}$ & 2011 & $>3,51$ & Akmen & Anggaran & SPM & 3 & 3 & 3 & 3 & 3 & 0 & 10000 & NONE \\
\hline 14 & 20 & $\mathrm{P}$ & 2011 & $>3,51$ & Akmen & Anggaran & SPM & 5 & 7 & 8 & 6 & 7 & 0.16667 & 10100 & NONE \\
\hline 15 & 20 & $\mathrm{~L}$ & 2011 & $3,26-3,50$ & Akmen & Anggaran & SPM & 5 & 8 & 9 & 6.5 & 7 & 0.30769 & 10200 & NONE \\
\hline 16 & 21 & $\mathrm{P}$ & 2011 & $3,26-3,50$ & Akmen & Anggaran & SPM & 5 & 6 & 7 & 5.5 & 7 & 0 & 10000 & NONE \\
\hline 17 & 20 & $\mathrm{P}$ & 2011 & $>3,51$ & Akmen & Anggaran & SPM & 8 & 9 & 12 & 8.5 & 9 & 0.35294 & 10300 & NONE \\
\hline 18 & 21 & $\mathrm{P}$ & 2011 & $>3,51$ & Akmen & Anggaran & & 7 & 8 & 12 & 7.5 & 7 & 0.66667 & 10500 & NONE \\
\hline 19 & 21 & $\mathrm{P}$ & 2011 & $>3,51$ & Akmen & Anggaran & & 7 & 8 & 10 & 7.5 & 8 & 0.26667 & 10200 & NONE \\
\hline
\end{tabular}




\begin{tabular}{|c|c|c|c|c|c|c|c|c|c|c|c|c|c|c|c|}
\hline 20 & 21 & $\mathrm{P}$ & 2011 & $>3,51$ & Akmen & Anggaran & & 7 & 8 & 10 & 7.5 & 7 & 0.4 & 10300 & NONE \\
\hline 21 & 21 & $\mathrm{P}$ & 2011 & $>3,51$ & Akmen & Anggaran & & 5 & 7 & 8 & 6 & 7 & 0.16667 & 10100 & NONE \\
\hline 22 & 20 & $\mathrm{P}$ & 2011 & $>3,51$ & Akmen & Anggaran & & 4 & 7 & 7 & 5.5 & 7 & 0 & 10000 & NONE \\
\hline 23 & 20 & $\mathrm{P}$ & 2011 & $3,00-3,25$ & Akmen & Anggaran & & 3 & 5 & 7 & 4 & 4 & 0.75 & 10300 & NONE \\
\hline 24 & 21 & $\mathrm{~L}$ & 2010 & $3,26-3,50$ & Akmen & Anggaran & SPM & 6 & 5 & 6 & 5.5 & 5 & 0.18182 & 10100 & NONE \\
\hline 25 & 21 & $\mathrm{~L}$ & 2011 & $>3,51$ & Akmen & Anggaran & & 4 & 5 & 6 & 4.5 & 5 & 0.22222 & 10100 & NONE \\
\hline 26 & 20 & $\mathrm{P}$ & 2011 & $>3,51$ & Akmen & Anggaran & & 4 & 5 & 5 & 4.5 & 4 & 0.22222 & 10100 & NONE \\
\hline 27 & 21 & $\mathrm{P}$ & 2011 & $>3,51$ & Akmen & Anggaran & & 6 & 8 & 11 & 7 & 7 & 0.57143 & 10400 & NONE \\
\hline 28 & 22 & $\mathrm{~L}$ & 2010 & $3,00-3,25$ & Akmen & Anggaran & SPM & 4 & 4 & 5 & 4 & 4 & 0.25 & 10100 & NONE \\
\hline 29 & 21 & $\mathrm{P}$ & 2010 & $>3,51$ & Akmen & Anggaran & SPM & 5 & 5 & 7 & 5 & 7 & 0 & 10000 & NONE \\
\hline 30 & 22 & $\mathrm{~L}$ & 2010 & $3,26-3,50$ & Akmen & Anggaran & SPM & 3 & 3 & 4 & 3 & 3 & 0.33333 & 10100 & NONE \\
\hline 31 & 21 & $\mathrm{P}$ & 2011 & $>3,51$ & Akmen & Anggaran & & 2 & 4 & 5 & 3 & 5 & 0 & 10000 & NONE \\
\hline 32 & 21 & $\mathrm{P}$ & 2011 & $>3,51$ & Akmen & Anggaran & & 4 & 6 & 9 & 5 & 9 & 0 & 10000 & NONE \\
\hline 33 & 21 & $\mathrm{P}$ & 2011 & $3,26-3,50$ & Akmen & Anggaran & & 4 & 6 & 7 & 5 & 6 & 0.2 & 10100 & NONE \\
\hline 34 & 20 & $\mathrm{P}$ & 2011 & $3,26-3,50$ & Akmen & Anggaran & & 3 & 5 & 7 & 4 & 6 & 0.25 & 10100 & NONE \\
\hline 35 & 21 & $\mathrm{~L}$ & 2011 & $3,00-3,25$ & Akmen & Anggaran & & 8 & 10 & 10 & 9 & 9 & 0.11111 & 10100 & NONE \\
\hline 36 & 21 & $\mathrm{~L}$ & 2011 & $3,26-3,50$ & Akmen & Anggaran & & 2 & 3 & 3 & 2.5 & 1 & 0.8 & 10200 & NONE \\
\hline 37 & 22 & $\mathrm{~L}$ & 2010 & $3,00-3,25$ & Akmen & Anggaran & SPM & 6 & 5 & 5 & 5.5 & 5 & 0 & 10000 & NONE \\
\hline 38 & 22 & $\mathrm{P}$ & 2010 & $>3,51$ & Akmen & Anggaran & SPM & 3 & 5 & 6 & 4 & 3 & 0.75 & 10300 & NONE \\
\hline 39 & 21 & $\mathrm{~L}$ & 2010 & $>3,51$ & Akmen & Anggaran & SPM & 4 & 6 & 7 & 5 & 7 & 0 & 10000 & NONE \\
\hline 40 & 22 & $\mathrm{P}$ & 2010 & $3,26-3,50$ & Akmen & Anggaran & SPM & 8 & 9 & 10 & 8.5 & 9 & 0.11765 & 10100 & NONE \\
\hline 41 & 20 & $\mathrm{~L}$ & 2011 & $3,00-3,25$ & Akmen & Anggaran & & 2 & 2 & 3 & 2 & 2 & 0.5 & 10100 & NONE \\
\hline
\end{tabular}




\begin{tabular}{|c|c|c|c|c|c|c|c|c|c|c|c|c|c|c|c|}
\hline \multirow{2}{*}{$\begin{array}{r}\text { No } \\
42 \\
\end{array}$} & \multirow{2}{*}{$\begin{array}{c}\text { Umur } \\
21 \\
\end{array}$} & \multirow{2}{*}{$\begin{array}{c}\begin{array}{c}\text { Jenis } \\
\text { Kelamin }\end{array} \\
\mathrm{P} \\
\end{array}$} & \multirow{2}{*}{$\begin{array}{c}\text { Angkatan } \\
2011 \\
\end{array}$} & \multirow{2}{*}{$\begin{array}{c}\text { IPK } \\
>3,51 \\
\end{array}$} & \multicolumn{3}{|c|}{$\begin{array}{c}\text { Mata Kuliah yang sudah } \\
\text { Lulus }\end{array}$} & \multicolumn{3}{|c|}{ Produksi } & \multirow{2}{*}{$\begin{array}{l}\text { Exp. } \\
\text { Perf. } \\
6.5 \\
\end{array}$} & \multirow{2}{*}{$\begin{array}{r}\text { Target } \\
8 \\
\end{array}$} & \multirow{2}{*}{$\begin{array}{c}\text { Slack } \\
0.15385 \\
\end{array}$} & \multirow{2}{*}{$\begin{array}{r}\text { Kompensasi } \\
10100 \\
\end{array}$} & \multirow{2}{*}{$\begin{array}{l}\text { Kasus } \\
\text { NONE } \\
\end{array}$} \\
\hline & & & & & Akmen & Anggaran & & 6 & 7 & 9 & & & & & \\
\hline 43 & 20 & $\mathrm{P}$ & 2011 & $>3,51$ & Akmen & Anggaran & & 6 & 7 & 8 & 6.5 & 5 & 0.46154 & 10300 & NONE \\
\hline 44 & 20 & $\mathrm{P}$ & 2011 & $>3,51$ & Akmen & Anggaran & & 8 & 8 & 11 & 8 & 10 & 0.125 & 10100 & NONE \\
\hline 45 & 20 & $\mathrm{P}$ & 2011 & $>3,51$ & Akmen & Anggaran & & 6 & 8 & 10 & 7 & 10 & 0 & 10000 & NONE \\
\hline 46 & 21 & $\mathrm{P}$ & 2011 & $3,26-3,50$ & Akmen & Anggaran & & 2 & 5 & 5 & 3.5 & 4 & 0.28571 & 10100 & NONE \\
\hline 47 & 21 & $\mathrm{~L}$ & 2011 & $3,00-3,25$ & Akmen & Anggaran & SPM & 4 & 5 & 6 & 4.5 & 4 & 0.44444 & 10200 & LOW \\
\hline 48 & 22 & $\mathrm{P}$ & 2010 & $3,26-3,50$ & Akmen & Anggaran & SPM & 5 & 6 & 6 & 5.5 & 5 & 0.18182 & 10100 & LOW \\
\hline 49 & 20 & $\mathrm{P}$ & 2010 & $>3,51$ & Akmen & Anggaran & SPM & 3 & 4 & 5 & 3.5 & 4 & 0.28571 & 10100 & LOW \\
\hline 50 & 21 & $\mathrm{~L}$ & 2010 & $3,26-3,50$ & Akmen & Anggaran & SPM & 3 & 3 & 4 & 3 & 3 & 0.33333 & 10100 & LOW \\
\hline 51 & 21 & $\mathrm{~L}$ & 2010 & $3,00-3,25$ & Akmen & Anggaran & SPM & 5 & 5 & 6 & 5 & 5 & 0.2 & 10100 & LOW \\
\hline 52 & 20 & $\mathrm{P}$ & 2010 & $>3,51$ & Akmen & Anggaran & SPM & 6 & 6 & 6 & 6 & 5 & 0.16667 & 10100 & LOW \\
\hline 53 & 20 & $\mathrm{~L}$ & 2010 & $3,26-3,50$ & Akmen & Anggaran & SPM & 4 & 5 & 6 & 4.5 & 5 & 0.22222 & 10100 & LOW \\
\hline 54 & 21 & $\mathrm{~L}$ & 2011 & $>3,51$ & Akmen & Anggaran & SPM & 2 & 3 & 3 & 2.5 & 2 & 0.4 & 10100 & LOW \\
\hline 55 & 21 & $\mathrm{~L}$ & 2011 & $3,26-3,50$ & Akmen & Anggaran & SPM & 3 & 3 & 3 & 3 & 1 & 0.66667 & 10200 & LOW \\
\hline 56 & 21 & $\mathrm{P}$ & 2011 & $3,26-3,50$ & Akmen & Anggaran & SPM & 5 & 6 & 7 & 5.5 & 5 & 0.36364 & 10200 & LOW \\
\hline 57 & 21 & $\mathrm{~L}$ & 2011 & $3,00-3,25$ & Akmen & Anggaran & SPM & 3 & 3 & 3 & 3 & 3 & 0 & 10000 & LOW \\
\hline 58 & 21 & $\mathrm{P}$ & 2011 & $>3,51$ & Akmen & Anggaran & SPM & 7 & 8 & 9 & 7.5 & 8 & 0.13333 & 10100 & LOW \\
\hline 59 & 20 & $\mathrm{P}$ & 2011 & $3,26-3,50$ & Akmen & Anggaran & SPM & 3 & 3 & 5 & 3 & 3 & 0.66667 & 10200 & LOW \\
\hline 60 & 21 & $\mathrm{P}$ & 2011 & $3,00-3,25$ & Akmen & Anggaran & SPM & 4 & 6 & 7 & 5 & 4 & 0.6 & 10300 & LOW \\
\hline 61 & 19 & $\mathrm{~L}$ & 2011 & $3,26-3,50$ & Akmen & Anggaran & SPM & 3 & 4 & 5 & 3.5 & 4 & 0.28571 & 10100 & LOW \\
\hline
\end{tabular}




\begin{tabular}{|c|c|c|c|c|c|c|c|c|c|c|c|c|c|c|c|}
\hline \multirow{2}{*}{$\begin{array}{r}\text { No } \\
62 \\
\end{array}$} & \multirow{2}{*}{$\begin{array}{l}\text { Umur } \\
>22 \\
\end{array}$} & \multirow{2}{*}{$\begin{array}{c}\begin{array}{c}\text { Jenis } \\
\text { Kelamin }\end{array} \\
\mathrm{P} \\
\end{array}$} & \multirow{2}{*}{$\begin{array}{c}\text { Angkatan } \\
2010 \\
\end{array}$} & \multirow{2}{*}{$\begin{array}{c}\text { IPK } \\
>3,51 \\
\end{array}$} & \multicolumn{3}{|c|}{$\begin{array}{l}\text { Mata Kuliah yang sudah } \\
\text { Lulus }\end{array}$} & \multicolumn{3}{|c|}{ Produksi } & \multirow{2}{*}{$\begin{array}{r}\text { Exp. } \\
\text { Perf. }\end{array}$} & \multirow{2}{*}{$\begin{array}{r}\text { Target } \\
4 \\
\end{array}$} & \multirow{2}{*}{$\begin{array}{c}\text { Slack } \\
0.66667 \\
\end{array}$} & \multirow{2}{*}{$\begin{array}{r}\text { Kompensasi } \\
10300 \\
\end{array}$} & \multirow{2}{*}{$\begin{array}{l}\text { Kasus } \\
\text { LOW } \\
\end{array}$} \\
\hline & & & & & Akmen & Anggaran & SPM & 4 & 5 & 7 & & & & & \\
\hline 63 & 21 & $\mathrm{P}$ & 2011 & $>3,51$ & Akmen & Anggaran & SPM & 7 & 7 & 8 & 7 & 6 & 0.28571 & 10200 & LOW \\
\hline 64 & 20 & $\mathrm{P}$ & 2011 & $>3,51$ & Akmen & Anggaran & SPM & 7 & 8 & 9 & 7.5 & 7 & 0.26667 & 10200 & LOW \\
\hline 65 & 21 & $\mathrm{~L}$ & 2011 & $3,00-3,25$ & Akmen & Anggaran & SPM & 3 & 3 & 3 & 3 & 3 & 0 & 10000 & LOW \\
\hline 66 & 20 & $\mathrm{P}$ & 2011 & $>3,51$ & Akmen & Anggaran & SPM & 6 & 6 & 8 & 6 & 5 & 0.5 & 10300 & LOW \\
\hline 67 & 21 & $\mathrm{P}$ & 2011 & $3,26-3,50$ & Akmen & Anggaran & SPM & 4 & 6 & 8 & 5 & 4 & 0.8 & 10400 & LOW \\
\hline 68 & 20 & $\mathrm{P}$ & 2011 & $3,26-3,50$ & Akmen & Anggaran & SPM & 4 & 4 & 5 & 4 & 4 & 0.25 & 10100 & LOW \\
\hline 69 & 21 & $\mathrm{~L}$ & 2011 & $3,26-3,50$ & Akmen & Anggaran & SPM & 4 & 4 & 4 & 4 & 4 & 0 & 10000 & LOW \\
\hline 70 & 22 & $\mathrm{P}$ & 2011 & $>3,51$ & Akmen & Anggaran & & 4 & 5 & 6 & 4.5 & 4 & 0.44444 & 10200 & LOW \\
\hline 71 & 21 & $\mathrm{~L}$ & 2011 & $3,00-3,25$ & Akmen & Anggaran & & 3 & 3 & 4 & 3 & 3 & 0.33333 & 10100 & LOW \\
\hline 72 & 21 & $\mathrm{~L}$ & 2011 & $3,00-3,25$ & Akmen & Anggaran & & 4 & 5 & 6 & 4.5 & 5 & 0.22222 & 10100 & LOW \\
\hline 73 & 21 & $\mathrm{P}$ & 2011 & $3,26-3,50$ & Akmen & Anggaran & & 3 & 5 & 6 & 4 & 3 & 0.75 & 10300 & LOW \\
\hline 74 & 21 & $\mathrm{~L}$ & 2011 & $3,00-3,25$ & Akmen & Anggaran & & 2 & 3 & 4 & 2.5 & 3 & 0.4 & 10100 & LOW \\
\hline 75 & $>22$ & $\mathrm{~L}$ & 2011 & $3,26-3,50$ & Akmen & Anggaran & & 3 & 3 & 5 & 3 & 3 & 0.66667 & 10200 & LOW \\
\hline 76 & 20 & $\mathrm{P}$ & 2011 & $>3,51$ & Akmen & Anggaran & & 6 & 8 & 9 & 7 & 6 & 0.42857 & 10300 & LOW \\
\hline 77 & 20 & $\mathrm{P}$ & 2011 & $3,26-3,50$ & Akmen & Anggaran & & 3 & 4 & 6 & 3.5 & 4 & 0.57143 & 10200 & LOW \\
\hline 78 & 20 & $\mathrm{P}$ & 2011 & $3,00-3,25$ & Akmen & Anggaran & & 5 & 7 & 9 & 6 & 6 & 0.5 & 10300 & LOW \\
\hline 79 & 21 & $\mathrm{~L}$ & 2011 & $3,00-3,25$ & Akmen & Anggaran & & 4 & 4 & 4 & 4 & 4 & 0 & 10000 & LOW \\
\hline 80 & 21 & $\mathrm{P}$ & 2011 & $3,00-3,25$ & Akmen & Anggaran & & 7 & 9 & 10 & 8 & 7 & 0.375 & 10300 & LOW \\
\hline 81 & 20 & $\mathrm{P}$ & 2011 & $3,26-3,50$ & Akmen & Anggaran & & 2 & 4 & 5 & 3 & 2 & 1 & 10300 & LOW \\
\hline
\end{tabular}




\begin{tabular}{|c|c|c|c|c|c|c|c|c|c|c|c|c|c|c|c|}
\hline \multirow{2}{*}{$\begin{array}{r}\text { No } \\
82 \\
\end{array}$} & \multirow{2}{*}{$\begin{array}{c}\text { Umur } \\
20 \\
\end{array}$} & \multirow{2}{*}{$\begin{array}{c}\begin{array}{c}\text { Jenis } \\
\text { Kelamin }\end{array} \\
\mathrm{P} \\
\end{array}$} & \multirow{2}{*}{$\begin{array}{c}\text { Angkatan } \\
2011\end{array}$} & \multirow{2}{*}{$\begin{array}{c}\text { IPK } \\
3,26-3,50 \\
\end{array}$} & \multicolumn{3}{|c|}{$\begin{array}{l}\text { Mata Kuliah yang sudah } \\
\text { Lulus }\end{array}$} & \multicolumn{3}{|c|}{ Produksi } & \multirow{2}{*}{$\begin{array}{r}\text { Exp. } \\
\text { Perf. } \\
4 \\
\end{array}$} & \multirow{2}{*}{$\begin{array}{r}\text { Target } \\
\\
2 \\
\end{array}$} & \multirow{2}{*}{$\begin{array}{r}\text { Slack } \\
1 \\
\end{array}$} & \multirow{2}{*}{$\begin{array}{r}\text { Kompensasi } \\
10400 \\
\end{array}$} & \multirow{2}{*}{$\begin{array}{l}\text { Kasus } \\
\text { LOW }\end{array}$} \\
\hline & & & & & Akmen & Anggaran & & 3 & 5 & 6 & & & & & \\
\hline 83 & 20 & $\mathrm{P}$ & 2011 & $3,00-3,25$ & Akmen & Anggaran & & 5 & 5 & 6 & 5 & 4 & 0.4 & 10200 & LOW \\
\hline 84 & 20 & $\mathrm{~L}$ & 2011 & $3,00-3,25$ & Akmen & Anggaran & & 5 & 5 & 6 & 5 & 4 & 0.4 & 10200 & LOW \\
\hline 85 & 21 & $\mathrm{~L}$ & 2011 & $3,26-3,50$ & Akmen & Anggaran & & 3 & 4 & 4 & 3.5 & 3 & 0.28571 & 10100 & LOW \\
\hline 86 & 21 & $\mathrm{~L}$ & 2011 & $3,00-3,25$ & Akmen & Anggaran & & 3 & 3 & 3 & 3 & 2 & 0.33333 & 10100 & LOW \\
\hline 87 & 21 & $\mathrm{~L}$ & 2011 & $3,00-3,25$ & Akmen & Anggaran & & 3 & 4 & 5 & 3.5 & 3 & 0.57143 & 10200 & LOW \\
\hline 88 & 20 & $\mathrm{P}$ & 2011 & $3,26-3,50$ & Akmen & Anggaran & & 4 & 5 & 5 & 4.5 & 4 & 0.22222 & 10100 & LOW \\
\hline 89 & 21 & $\mathrm{~L}$ & 2011 & $>3,51$ & Akmen & Anggaran & & 5 & 6 & 8 & 5.5 & 5 & 0.54545 & 10300 & LOW \\
\hline 90 & 20 & $\mathrm{P}$ & 2011 & $3,26-3,50$ & Akmen & Anggaran & & 3 & 3 & 4 & 3 & 3 & 0.33333 & 10100 & LOW \\
\hline 91 & 21 & $\mathrm{~L}$ & 2011 & $3,26-3,50$ & Akmen & Anggaran & & 4 & 4 & 5 & 4 & 2 & 0.75 & 10300 & LOW \\
\hline 92 & 20 & $\mathrm{P}$ & 2011 & $3,00-3,25$ & Akmen & Anggaran & & 4 & 4 & 4 & 4 & 3 & 0.25 & 10100 & LOW \\
\hline 93 & 20 & $\mathrm{~L}$ & 2011 & $3,00-3,25$ & Akmen & Anggaran & & 2 & 3 & 4 & 2.5 & 2 & 0.8 & 10200 & LOW \\
\hline 94 & 20 & $\mathrm{P}$ & 2011 & $>3,51$ & Akmen & Anggaran & SPM & 4 & 5 & 6 & 4.5 & 2 & 0.88889 & 10400 & $\mathrm{HIGH}$ \\
\hline 95 & 20 & $\mathrm{P}$ & 2011 & $3,26-3,50$ & Akmen & Anggaran & SPM & 6 & 7 & 8 & 6.5 & 5 & 0.46154 & 10300 & HIGH \\
\hline 96 & 22 & $\mathrm{~L}$ & 2010 & $>3,51$ & Akmen & Anggaran & SPM & 4 & 4 & 6 & 4 & 5 & 0.25 & 10100 & $\mathrm{HIGH}$ \\
\hline 97 & 21 & $\mathrm{~L}$ & 2010 & $3,26-3,50$ & Akmen & Anggaran & SPM & 4 & 5 & 6 & 4.5 & 4 & 0.44444 & 10200 & HIGH \\
\hline 98 & 21 & $\mathrm{P}$ & 2010 & $>3,51$ & Akmen & Anggaran & SPM & 6 & 7 & 8 & 6.5 & 8 & 0 & 10000 & $\mathrm{HIGH}$ \\
\hline 99 & 20 & $\mathrm{P}$ & 2011 & $3,26-3,50$ & Akmen & Anggaran & SPM & 4 & 6 & 6 & 5 & 3 & 0.6 & 10300 & $\mathrm{HIGH}$ \\
\hline 100 & 20 & $\mathrm{P}$ & 2011 & $3,00-3,25$ & Akmen & Anggaran & SPM & 3 & 5 & 7 & 4 & 5 & 0.5 & 10200 & $\mathrm{HIGH}$ \\
\hline 101 & 20 & $\mathrm{P}$ & 2011 & $3,26-3,50$ & Akmen & Anggaran & SPM & 5 & 7 & 7 & 6 & 6 & 0.16667 & 10100 & $\mathrm{HIGH}$ \\
\hline
\end{tabular}




\begin{tabular}{|c|c|c|c|c|c|c|c|c|c|c|c|c|c|c|c|}
\hline \multirow{2}{*}{$\begin{array}{l}\text { No } \\
102 \\
\end{array}$} & \multirow{2}{*}{$\begin{array}{c}\text { Umur } \\
22 \\
\end{array}$} & \multirow{2}{*}{$\begin{array}{c}\begin{array}{c}\text { Jenis } \\
\text { Kelamin }\end{array} \\
\mathrm{P} \\
\end{array}$} & \multirow{2}{*}{$\begin{array}{c}\text { Angkatan } \\
2011 \\
\end{array}$} & \multirow{2}{*}{$\begin{array}{c}\text { IPK } \\
>3,51 \\
\end{array}$} & \multicolumn{3}{|c|}{$\begin{array}{l}\text { Mata Kuliah yang sudah } \\
\text { Lulus }\end{array}$} & \multicolumn{3}{|c|}{ Produksi } & \multirow{2}{*}{$\begin{array}{r}\text { Exp. } \\
\text { Perf. }\end{array}$} & \multirow{2}{*}{$\begin{array}{r}\text { Target } \\
3 \\
\end{array}$} & \multirow{2}{*}{$\begin{array}{c}\text { Slack } \\
0.57143 \\
\end{array}$} & \multirow{2}{*}{$\begin{array}{r}\text { Kompensasi } \\
10200 \\
\end{array}$} & \multirow{2}{*}{$\begin{array}{l}\text { Kasus } \\
\text { HIGH } \\
\end{array}$} \\
\hline & & & & & Akmen & Anggaran & SPM & 3 & 4 & 5 & & & & & \\
\hline 103 & 21 & $\mathrm{P}$ & 2011 & $3,26-3,50$ & Akmen & Anggaran & SPM & 4 & 6 & 8 & 5 & 4 & 0.8 & 10400 & HIGH \\
\hline 104 & 20 & $\mathrm{P}$ & 2011 & $3,26-3,50$ & Akmen & Anggaran & SPM & 4 & 6 & 8 & 5 & 4 & 0.8 & 10400 & HIGH \\
\hline 105 & 20 & $\mathrm{P}$ & 2011 & $3,26-3,50$ & Akmen & Anggaran & SPM & 6 & 7 & 9 & 6.5 & 4 & 0.76923 & 10500 & HIGH \\
\hline 106 & 20 & $\mathrm{P}$ & 2011 & $>3,51$ & Akmen & Anggaran & SPM & 4 & 6 & 6 & 5 & 1 & 1 & 10500 & HIGH \\
\hline 107 & 21 & $\mathrm{P}$ & 2011 & $>3,51$ & Akmen & Anggaran & SPM & 5 & 6 & 8 & 5.5 & 7 & 0.18182 & 10100 & HIGH \\
\hline 108 & 21 & $\mathrm{P}$ & 2011 & $>3,51$ & Akmen & Anggaran & SPM & 8 & 9 & 11 & 8.5 & 6 & 0.58824 & 10500 & HIGH \\
\hline 109 & 20 & $\mathrm{P}$ & 2011 & $3,26-3,50$ & Akmen & Anggaran & SPM & 3 & 6 & 7 & 4.5 & 4 & 0.66667 & 10300 & HIGH \\
\hline 110 & $>22$ & $\mathrm{P}$ & 2010 & $>3,51$ & Akmen & Anggaran & SPM & 7 & 8 & 11 & 7.5 & 10 & 0.13333 & 10100 & HIGH \\
\hline 111 & 21 & $\mathrm{P}$ & 2010 & $>3,51$ & Akmen & Anggaran & SPM & 8 & 9 & 9 & 8.5 & 4 & 0.58824 & 10500 & HIGH \\
\hline 112 & 22 & $\mathrm{P}$ & 2011 & $>3,51$ & Akmen & Anggaran & SPM & 3 & 4 & 4 & 3.5 & 1 & 0.85714 & 10300 & $\mathrm{HIGH}$ \\
\hline 113 & 21 & $\mathrm{~L}$ & 2011 & $3,26-3,50$ & Akmen & Anggaran & SPM & 3 & 4 & 5 & 3.5 & 4 & 0.28571 & 10100 & $\mathrm{HIGH}$ \\
\hline 114 & 20 & $\mathrm{P}$ & 2011 & $3,26-3,50$ & Akmen & Anggaran & SPM & 4 & 5 & 7 & 4.5 & 5 & 0.44444 & 10200 & $\mathrm{HIGH}$ \\
\hline 115 & 21 & $\mathrm{~L}$ & 2011 & $3,26-3,50$ & Akmen & Anggaran & SPM & 7 & 8 & 10 & 7.5 & 10 & 0 & 10000 & HIGH \\
\hline 116 & 20 & $\mathrm{P}$ & 2011 & $>3,51$ & Akmen & Anggaran & & 6 & 7 & 9 & 6.5 & 6 & 0.46154 & 10300 & $\mathrm{HIGH}$ \\
\hline 117 & 22 & $\mathrm{P}$ & 2011 & $>3,51$ & Akmen & Anggaran & & 5 & 6 & 7 & 5.5 & 3 & 0.72727 & 10400 & HIGH \\
\hline 118 & 21 & $\mathrm{~L}$ & 2011 & $3,26-3,50$ & Akmen & Anggaran & & 3 & 3 & 4 & 3 & 1 & 1 & 10300 & $\mathrm{HIGH}$ \\
\hline 119 & 20 & $\mathrm{P}$ & 2011 & $3,26-3,50$ & Akmen & Anggaran & & 9 & 10 & 11 & 9.5 & 6 & 0.52632 & 10500 & HIGH \\
\hline 120 & 21 & $\mathrm{~L}$ & 2011 & $3,00-3,25$ & Akmen & Anggaran & & 3 & 3 & 4 & 3 & 1 & 1 & 10300 & $\mathrm{HIGH}$ \\
\hline 121 & 21 & $P$ & 2011 & $3,26-3,50$ & Akmen & Anggaran & & 3 & 4 & 5 & 3.5 & 3 & 0.57143 & 10200 & HIGH \\
\hline
\end{tabular}




\begin{tabular}{|c|c|c|c|c|c|c|c|c|c|c|c|c|c|c|c|}
\hline \multirow{2}{*}{$\begin{array}{l}\text { No } \\
122 \\
\end{array}$} & \multirow{2}{*}{$\begin{array}{c}\text { Umur } \\
19 \\
\end{array}$} & \multirow{2}{*}{$\begin{array}{c}\begin{array}{c}\text { Jenis } \\
\text { Kelamin }\end{array} \\
\mathrm{L} \\
\end{array}$} & \multirow{2}{*}{$\begin{array}{c}\text { Angkatan } \\
2011 \\
\end{array}$} & \multirow{2}{*}{$\begin{array}{c}\text { IPK } \\
3,26-3,50 \\
\end{array}$} & \multicolumn{3}{|c|}{$\begin{array}{c}\text { Mata Kuliah yang sudah } \\
\text { Lulus }\end{array}$} & \multicolumn{3}{|c|}{ Produksi } & \multirow{2}{*}{$\begin{array}{r}\text { Exp. } \\
\text { Perf. } \\
10 \\
\end{array}$} & \multirow{2}{*}{$\begin{array}{r}\text { Target } \\
8 \\
\end{array}$} & \multirow{2}{*}{$\begin{array}{r}\text { Slack } \\
0.4\end{array}$} & \multirow{2}{*}{$\begin{array}{r}\text { Kompensasi } \\
10400 \\
\end{array}$} & \multirow{2}{*}{$\begin{array}{l}\text { Kasus } \\
\text { HIGH } \\
\end{array}$} \\
\hline & & & & & Akmen & Anggaran & & 10 & 10 & 12 & & & & & \\
\hline 123 & 20 & $\mathrm{P}$ & 2011 & $3,26-3,50$ & Akmen & Anggaran & & 5 & 5 & 6 & 5 & 5 & 0.2 & 10100 & HIGH \\
\hline 124 & 20 & $\mathrm{~L}$ & 2011 & $3,00-3,25$ & Akmen & Anggaran & & 3 & 4 & 5 & 3.5 & 4 & 0.28571 & 10100 & HIGH \\
\hline 125 & 21 & $\mathrm{~L}$ & 2011 & $<3,00$ & Akmen & Anggaran & & 8 & 8 & 9 & 8 & 7 & 0.25 & 10200 & HIGH \\
\hline 126 & 21 & $\mathrm{P}$ & 2011 & $3,26-3,50$ & Akmen & Anggaran & & 4 & 6 & 9 & 5 & 4 & 1 & 10500 & HIGH \\
\hline 127 & 22 & $\mathrm{P}$ & 2010 & $>3,51$ & Akmen & Anggaran & SPM & 6 & 6 & 8 & 6 & 5 & 0.5 & 10300 & HIGH \\
\hline 128 & 20 & $\mathrm{~L}$ & 2011 & $3,26-3,50$ & Akmen & Anggaran & & 3 & 4 & 5 & 3.5 & 4 & 0.28571 & 10100 & HIGH \\
\hline 129 & 20 & $\mathrm{P}$ & 2011 & $3,00-3,25$ & Akmen & Anggaran & & 3 & 5 & 7 & 4 & 4 & 0.75 & 10300 & HIGH \\
\hline 130 & 21 & $\mathrm{~L}$ & 2011 & $3,00-3,25$ & Akmen & Anggaran & & 3 & 4 & 6 & 3.5 & 5 & 0.28571 & 10100 & $\mathrm{HIGH}$ \\
\hline 131 & 21 & $\mathrm{~L}$ & 2011 & $<3,00$ & Akmen & Anggaran & & 3 & 4 & 4 & 3.5 & 1 & 0.85714 & 10300 & HIGH \\
\hline 132 & 20 & $\mathrm{P}$ & 2011 & $>3,51$ & Akmen & Anggaran & & 7 & 8 & 10 & 7.5 & 6 & 0.53333 & 10400 & HIGH \\
\hline 133 & 21 & $\mathrm{P}$ & 2011 & $>3,51$ & Akmen & Anggaran & & 5 & 6 & 8 & 5.5 & 4 & 0.72727 & 10400 & HIGH \\
\hline 134 & 20 & $\mathrm{P}$ & 2011 & $3,26-3,50$ & Akmen & Anggaran & & 4 & 5 & 7 & 4.5 & 3 & 0.88889 & 10400 & HIGH \\
\hline 135 & 21 & $\mathrm{P}$ & 2011 & $>3,51$ & Akmen & Anggaran & & 4 & 4 & 6 & 4 & 2 & 1 & 10400 & HIGH \\
\hline 136 & 21 & $\mathrm{P}$ & 2010 & $>3,51$ & Akmen & Anggaran & SPM & 8 & 8 & 9 & 8 & 5 & 0.5 & 10400 & HIGH \\
\hline 137 & 21 & $\mathrm{P}$ & 2011 & $3,26-3,50$ & Akmen & Anggaran & & 8 & 10 & 11 & 9 & 4 & 0.77778 & 10700 & HIGH \\
\hline 138 & 21 & $\mathrm{P}$ & 2011 & $3,26-3,50$ & Akmen & Anggaran & & 7 & 9 & 11 & 8 & 4 & 0.875 & 10700 & HIGH \\
\hline 139 & 21 & $\mathrm{P}$ & 2011 & $3,00-3,25$ & Akmen & Anggaran & & 4 & 6 & 6 & 5 & 3 & 0.6 & 10300 & HIGH \\
\hline 140 & 21 & $\mathrm{P}$ & 2011 & $3,26-3,50$ & Akmen & Anggaran & & 5 & 7 & 8 & 6 & 5 & 0.5 & 10300 & $\mathrm{HIGH}$ \\
\hline 141 & 21 & $\mathrm{P}$ & 2011 & $3,26-3,50$ & Akmen & Anggaran & & 5 & 5 & 5 & 5 & 1 & 0.8 & 10400 & HIGH \\
\hline
\end{tabular}


Tabel 2. Diskripsi Data Intrumen Kuesioner Orientasi Etika

\begin{tabular}{|c|c|c|c|c|c|c|c|c|c|c|c|c|c|c|c|c|c|c|c|c|c|c|}
\hline \multirow[b]{2}{*}{ Subjek } & \multicolumn{11}{|c|}{ Butir Relativisme } & \multicolumn{11}{|c|}{ Butir Idealisme } \\
\hline & 1 & 2 & 3 & 4 & 5 & 6 & 7 & 8 & 9 & 10 & Skor & 1 & 2 & 3 & 4 & 5 & 6 & 7 & 8 & 9 & 10 & Skor \\
\hline 1 & 3 & 4 & 3 & 3 & 4 & 4 & 3 & 3 & 3 & 2 & 32 & 4 & 4 & 4 & 5 & 4 & 4 & 3 & 3 & 4 & 4 & 39 \\
\hline 2 & 2 & 4 & 4 & 3 & 4 & 3 & 3 & 2 & 4 & 3 & 32 & 5 & 3 & 4 & 4 & 5 & 5 & 3 & 4 & 4 & 4 & 41 \\
\hline 3 & 2 & 5 & 5 & 4 & 4 & 4 & 1 & 1 & 5 & 4 & 35 & 5 & 4 & 5 & 5 & 5 & 4 & 2 & 4 & 5 & 4 & 43 \\
\hline 4 & 3 & 4 & 4 & 4 & 5 & 5 & 4 & 4 & 4 & 3 & 40 & 4 & 2 & 5 & 5 & 4 & 5 & 3 & 4 & 4 & 5 & 41 \\
\hline 5 & 1 & 5 & 5 & 4 & 5 & 5 & 4 & 4 & 4 & 5 & 42 & 2 & 2 & 3 & 5 & 5 & 5 & 5 & 5 & 4 & 4 & 40 \\
\hline 6 & 3 & 4 & 4 & 4 & 4 & 4 & 2 & 4 & 2 & 2 & 33 & 4 & 4 & 3 & 5 & 4 & 4 & 3 & 4 & 4 & 5 & 40 \\
\hline 7 & 1 & 4 & 4 & 4 & 3 & 3 & 2 & 4 & 3 & 3 & 31 & 4 & 2 & 4 & 5 & 5 & 5 & 3 & 5 & 4 & 5 & 42 \\
\hline 8 & 2 & 3 & 4 & 2 & 3 & 4 & 3 & 4 & 2 & 2 & 29 & 4 & 3 & 3 & 4 & 5 & 5 & 4 & 4 & 5 & 5 & 42 \\
\hline 9 & 2 & 4 & 3 & 4 & 3 & 2 & 2 & 3 & 2 & 2 & 27 & 4 & 2 & 4 & 1 & 4 & 5 & 3 & 4 & 4 & 3 & 34 \\
\hline 10 & 2 & 2 & 2 & 3 & 2 & 2 & 3 & 2 & 3 & 2 & 23 & 2 & 2 & 4 & 4 & 2 & 2 & 3 & 3 & 2 & 2 & 26 \\
\hline 11 & 3 & 4 & 4 & 3 & 3 & 3 & 4 & 4 & 4 & 4 & 36 & 3 & 3 & 4 & 5 & 4 & 4 & 3 & 3 & 4 & 4 & 37 \\
\hline 12 & 3 & 4 & 4 & 3 & 3 & 3 & 4 & 5 & 3 & 3 & 35 & 3 & 3 & 4 & 4 & 4 & 4 & 2 & 2 & 2 & 3 & 31 \\
\hline 13 & 2 & 4 & 5 & 3 & 4 & 3 & 4 & 2 & 2 & 3 & 32 & 4 & 3 & 5 & 4 & 5 & 4 & 3 & 4 & 5 & 5 & 42 \\
\hline 14 & 2 & 4 & 3 & 4 & 3 & 3 & 3 & 4 & 2 & 3 & 31 & 5 & 3 & 4 & 5 & 5 & 4 & 3 & 3 & 3 & 4 & 39 \\
\hline 15 & 2 & 4 & 4 & 2 & 2 & 4 & 2 & 4 & 2 & 4 & 30 & 4 & 4 & 4 & 4 & 4 & 4 & 4 & 4 & 4 & 4 & 40 \\
\hline 16 & 3 & 5 & 4 & 3 & 3 & 3 & 2 & 3 & 3 & 2 & 31 & 4 & 3 & 4 & 5 & 4 & 3 & 3 & 4 & 4 & 3 & 37 \\
\hline 17 & 3 & 4 & 4 & 3 & 3 & 3 & 2 & 3 & 2 & 2 & 29 & 4 & 3 & 4 & 4 & 4 & 4 & 2 & 3 & 4 & 4 & 36 \\
\hline 18 & 3 & 4 & 4 & 4 & 4 & 2 & 2 & 3 & 3 & 3 & 32 & 2 & 4 & 4 & 4 & 5 & 4 & 3 & 4 & 4 & 3 & 37 \\
\hline
\end{tabular}




\begin{tabular}{|r|r|r|r|r|r|r|r|r|r|r|r|r|r|r|r|r|r|r|r|r|r|r|}
\hline Subjek & \multicolumn{10}{|c|}{ Butir Relativisme } \\
\hline & 1 & 2 & 3 & 4 & 5 & 6 & 7 & 8 & 9 & 10 & Total & 1 & 2 & 3 & 4 & 5 & 6 & 7 & 8 & 9 & 10 & Total \\
\hline 19 & 3 & 4 & 5 & 5 & 5 & 5 & 4 & 4 & 3 & 4 & 42 & 5 & 5 & 5 & 5 & 5 & 5 & 3 & 5 & 5 & 5 & 48 \\
\hline 20 & 2 & 4 & 4 & 3 & 3 & 4 & 3 & 3 & 4 & 4 & 34 & 4 & 4 & 4 & 5 & 5 & 4 & 2 & 4 & 5 & 4 & 41 \\
\hline 21 & 2 & 2 & 4 & 4 & 2 & 2 & 2 & 2 & 2 & 2 & 24 & 5 & 2 & 5 & 5 & 4 & 4 & 5 & 4 & 4 & 5 & 43 \\
\hline 22 & 2 & 4 & 5 & 4 & 4 & 3 & 2 & 4 & 4 & 4 & 36 & 4 & 4 & 4 & 4 & 4 & 4 & 3 & 4 & 4 & 4 & 39 \\
\hline 23 & 3 & 5 & 4 & 3 & 5 & 4 & 3 & 5 & 3 & 3 & 38 & 4 & 4 & 5 & 5 & 4 & 4 & 3 & 5 & 5 & 5 & 44 \\
\hline 24 & 2 & 4 & 3 & 3 & 3 & 3 & 4 & 4 & 4 & 5 & 35 & 4 & 4 & 3 & 5 & 4 & 4 & 3 & 4 & 3 & 2 & 36 \\
\hline 25 & 2 & 4 & 4 & 4 & 4 & 4 & 4 & 4 & 4 & 4 & 38 & 4 & 2 & 4 & 4 & 4 & 4 & 2 & 4 & 4 & 2 & 34 \\
\hline 26 & 4 & 3 & 5 & 5 & 1 & 4 & 4 & 5 & 5 & 1 & 37 & 2 & 5 & 4 & 4 & 2 & 4 & 2 & 4 & 5 & 4 & 36 \\
\hline 27 & 3 & 4 & 4 & 4 & 4 & 4 & 2 & 4 & 4 & 3 & 36 & 4 & 4 & 5 & 4 & 4 & 4 & 3 & 4 & 4 & 4 & 40 \\
\hline 28 & 2 & 4 & 4 & 4 & 2 & 3 & 2 & 4 & 2 & 1 & 28 & 4 & 3 & 4 & 5 & 4 & 4 & 2 & 3 & 4 & 4 & 37 \\
\hline 29 & 3 & 4 & 4 & 3 & 4 & 4 & 3 & 4 & 4 & 4 & 37 & 4 & 2 & 4 & 5 & 5 & 4 & 3 & 3 & 3 & 4 & 37 \\
\hline 30 & 2 & 4 & 4 & 4 & 4 & 4 & 4 & 4 & 4 & 2 & 36 & 2 & 4 & 4 & 4 & 4 & 4 & 4 & 4 & 4 & 4 & 38 \\
\hline 31 & 2 & 3 & 3 & 3 & 3 & 4 & 4 & 2 & 3 & 2 & 29 & 4 & 2 & 3 & 5 & 5 & 4 & 3 & 3 & 4 & 2 & 35 \\
\hline 32 & 2 & 3 & 3 & 3 & 3 & 4 & 4 & 2 & 4 & 4 & 32 & 4 & 3 & 4 & 4 & 4 & 4 & 4 & 3 & 3 & 3 & 36 \\
\hline 33 & 1 & 2 & 4 & 4 & 3 & 2 & 2 & 2 & 1 & 2 & 23 & 5 & 4 & 5 & 5 & 5 & 5 & 2 & 4 & 4 & 5 & 44 \\
\hline 34 & 2 & 4 & 3 & 4 & 4 & 4 & 2 & 3 & 4 & 4 & 34 & 4 & 4 & 5 & 4 & 4 & 4 & 3 & 5 & 4 & 3 & 40 \\
\hline 35 & 1 & 5 & 4 & 4 & 4 & 5 & 3 & 3 & 4 & 4 & 37 & 2 & 2 & 5 & 5 & 5 & 5 & 2 & 5 & 4 & 4 & 39 \\
\hline 36 & 2 & 4 & 4 & 4 & 4 & 4 & 2 & 2 & 4 & 4 & 34 & 4 & 2 & 2 & 5 & 4 & 5 & 5 & 3 & 4 & 4 & 38 \\
\hline 37 & 1 & 4 & 4 & 4 & 4 & 4 & 1 & 4 & 4 & 4 & 34 & 5 & 1 & 3 & 4 & 4 & 4 & 3 & 4 & 4 & 3 & 35 \\
\hline 38 & 4 & 5 & 5 & 3 & 3 & 3 & 3 & 3 & 3 & 2 & 34 & 3 & 5 & 5 & 5 & 4 & 4 & 3 & 3 & 1 & 4 & 37 \\
\hline 39 & 2 & 4 & 3 & 3 & 3 & 3 & 3 & 4 & 3 & 3 & 31 & 4 & 4 & 5 & 4 & 4 & 4 & 3 & 4 & 4 & 4 & 40 \\
\hline
\end{tabular}




\begin{tabular}{|r|r|r|r|r|r|r|r|r|r|r|r|r|r|r|r|r|r|r|r|r|r|r|}
\hline Subjek & \multicolumn{10}{|c|}{ Butir Relativisme } & \multicolumn{10}{|c|}{ Butir Idealisme } \\
\hline & 1 & 2 & 3 & 4 & 5 & 6 & 7 & 8 & 9 & 10 & Total & 1 & 2 & 3 & 4 & 5 & 6 & 7 & 8 & 9 & 10 & Total \\
\hline 40 & 4 & 3 & 5 & 5 & 1 & 4 & 4 & 5 & 5 & 1 & 37 & 4 & 4 & 2 & 4 & 4 & 5 & 4 & 4 & 5 & 4 & 40 \\
\hline 41 & 2 & 4 & 4 & 4 & 4 & 5 & 4 & 2 & 2 & 3 & 34 & 4 & 2 & 4 & 4 & 5 & 5 & 2 & 4 & 4 & 4 & 38 \\
\hline 42 & 3 & 3 & 5 & 4 & 5 & 4 & 2 & 2 & 4 & 3 & 35 & 3 & 5 & 5 & 5 & 5 & 5 & 5 & 3 & 5 & 4 & 45 \\
\hline 43 & 2 & 4 & 4 & 4 & 3 & 5 & 2 & 4 & 2 & 2 & 32 & 5 & 4 & 5 & 5 & 5 & 4 & 4 & 4 & 5 & 3 & 44 \\
\hline 44 & 2 & 4 & 4 & 4 & 3 & 3 & 3 & 2 & 3 & 3 & 31 & 4 & 4 & 4 & 4 & 4 & 4 & 3 & 4 & 4 & 4 & 39 \\
\hline 45 & 5 & 4 & 5 & 5 & 5 & 4 & 4 & 4 & 4 & 4 & 44 & 2 & 4 & 4 & 4 & 3 & 4 & 4 & 4 & 4 & 4 & 37 \\
\hline 46 & 2 & 4 & 4 & 3 & 2 & 3 & 4 & 3 & 4 & 4 & 33 & 4 & 3 & 2 & 4 & 4 & 4 & 4 & 4 & 4 & 2 & 35 \\
\hline 47 & 2 & 4 & 5 & 4 & 4 & 4 & 2 & 4 & 4 & 4 & 37 & 5 & 4 & 5 & 5 & 5 & 5 & 3 & 4 & 4 & 5 & 45 \\
\hline 48 & 2 & 4 & 4 & 2 & 4 & 4 & 2 & 4 & 4 & 4 & 34 & 2 & 2 & 4 & 4 & 4 & 5 & 1 & 3 & 4 & 2 & 31 \\
\hline 49 & 2 & 4 & 4 & 4 & 4 & 4 & 4 & 4 & 4 & 4 & 38 & 4 & 3 & 3 & 3 & 3 & 3 & 3 & 2 & 2 & 2 & 28 \\
\hline 50 & 2 & 4 & 4 & 4 & 4 & 4 & 3 & 4 & 4 & 4 & 37 & 4 & 4 & 4 & 4 & 4 & 4 & 4 & 3 & 3 & 4 & 38 \\
\hline 51 & 3 & 5 & 4 & 4 & 4 & 4 & 3 & 4 & 4 & 4 & 39 & 5 & 4 & 4 & 4 & 4 & 5 & 3 & 4 & 4 & 4 & 41 \\
\hline 52 & 3 & 4 & 4 & 4 & 2 & 2 & 3 & 5 & 5 & 5 & 37 & 5 & 4 & 4 & 4 & 5 & 5 & 4 & 4 & 5 & 5 & 45 \\
\hline 53 & 4 & 4 & 3 & 4 & 4 & 4 & 3 & 4 & 4 & 5 & 39 & 3 & 4 & 3 & 3 & 4 & 4 & 4 & 4 & 4 & 4 & 37 \\
\hline 54 & 2 & 4 & 3 & 4 & 4 & 4 & 3 & 3 & 4 & 3 & 34 & 4 & 3 & 3 & 4 & 3 & 4 & 4 & 4 & 4 & 4 & 37 \\
\hline 55 & 5 & 5 & 5 & 5 & 5 & 5 & 5 & 1 & 4 & 4 & 44 & 4 & 2 & 4 & 5 & 5 & 4 & 3 & 4 & 4 & 4 & 39 \\
\hline 56 & 3 & 4 & 4 & 4 & 4 & 4 & 2 & 3 & 3 & 3 & 34 & 5 & 4 & 5 & 5 & 5 & 4 & 3 & 4 & 3 & 4 & 42 \\
\hline 57 & 4 & 4 & 5 & 4 & 4 & 4 & 1 & 2 & 4 & 2 & 34 & 4 & 3 & 3 & 4 & 4 & 4 & 4 & 3 & 4 & 4 & 37 \\
\hline 58 & 2 & 4 & 5 & 4 & 4 & 4 & 2 & 4 & 4 & 4 & 37 & 5 & 4 & 5 & 5 & 5 & 5 & 4 & 4 & 4 & 5 & 46 \\
\hline 59 & 3 & 4 & 3 & 4 & 4 & 4 & 2 & 3 & 4 & 3 & 34 & 4 & 3 & 5 & 4 & 4 & 4 & 1 & 3 & 4 & 1 & 33 \\
\hline 60 & 3 & 5 & 5 & 5 & 5 & 5 & 2 & 2 & 3 & 4 & 39 & 5 & 5 & 5 & 5 & 5 & 5 & 3 & 5 & 5 & 5 & 48 \\
\hline
\end{tabular}




\begin{tabular}{|r|r|r|r|r|r|r|r|r|r|r|r|r|r|r|r|r|r|r|r|r|r|r|}
\hline Subjek & \multicolumn{10}{|c|}{ Butir Relativisme } \\
\hline & 1 & 2 & 3 & 4 & 5 & 6 & 7 & 8 & 9 & 10 & Total & 1 & 2 & 3 & 4 & 5 & 6 & 7 & 8 & 9 & 10 & Total \\
\hline 61 & 3 & 4 & 4 & 3 & 4 & 4 & 3 & 4 & 4 & 3 & 36 & 4 & 2 & 4 & 5 & 5 & 4 & 3 & 4 & 4 & 4 & 39 \\
\hline 62 & 2 & 5 & 4 & 5 & 4 & 3 & 1 & 2 & 1 & 1 & 28 & 4 & 2 & 4 & 4 & 5 & 4 & 2 & 4 & 4 & 4 & 37 \\
\hline 63 & 1 & 4 & 5 & 4 & 4 & 3 & 1 & 2 & 2 & 3 & 29 & 2 & 2 & 3 & 4 & 4 & 4 & 2 & 4 & 4 & 4 & 33 \\
\hline 64 & 1 & 4 & 4 & 2 & 2 & 2 & 2 & 2 & 2 & 2 & 23 & 5 & 4 & 5 & 5 & 5 & 5 & 5 & 4 & 5 & 5 & 48 \\
\hline 65 & 4 & 4 & 5 & 4 & 4 & 4 & 1 & 2 & 4 & 2 & 34 & 4 & 4 & 4 & 4 & 5 & 4 & 3 & 4 & 4 & 5 & 41 \\
\hline 66 & 4 & 4 & 3 & 4 & 4 & 4 & 3 & 4 & 4 & 5 & 39 & 4 & 4 & 3 & 5 & 4 & 4 & 3 & 4 & 4 & 5 & 40 \\
\hline 67 & 2 & 4 & 5 & 4 & 4 & 4 & 2 & 4 & 4 & 4 & 37 & 4 & 1 & 4 & 4 & 4 & 1 & 4 & 4 & 3 & 4 & 33 \\
\hline 68 & 3 & 5 & 4 & 4 & 4 & 4 & 3 & 4 & 4 & 4 & 39 & 4 & 2 & 4 & 4 & 4 & 4 & 2 & 4 & 4 & 4 & 36 \\
\hline 69 & 3 & 4 & 3 & 4 & 4 & 4 & 2 & 3 & 4 & 3 & 34 & 5 & 4 & 5 & 5 & 4 & 5 & 3 & 4 & 4 & 5 & 44 \\
\hline 70 & 4 & 4 & 3 & 4 & 4 & 4 & 3 & 4 & 4 & 5 & 39 & 5 & 4 & 4 & 5 & 5 & 5 & 4 & 4 & 4 & 5 & 45 \\
\hline 71 & 2 & 4 & 4 & 2 & 4 & 2 & 2 & 2 & 2 & 2 & 26 & 2 & 2 & 3 & 4 & 4 & 4 & 2 & 4 & 4 & 4 & 33 \\
\hline 72 & 3 & 2 & 4 & 3 & 4 & 2 & 2 & 3 & 2 & 3 & 28 & 5 & 4 & 5 & 5 & 5 & 5 & 5 & 4 & 5 & 5 & 48 \\
\hline 73 & 2 & 4 & 4 & 4 & 2 & 2 & 2 & 4 & 2 & 3 & 29 & 4 & 4 & 4 & 4 & 4 & 4 & 3 & 4 & 4 & 4 & 39 \\
\hline 74 & 2 & 5 & 4 & 5 & 4 & 3 & 1 & 2 & 1 & 1 & 28 & 5 & 4 & 5 & 5 & 5 & 5 & 3 & 5 & 5 & 3 & 45 \\
\hline 75 & 1 & 4 & 4 & 2 & 2 & 2 & 2 & 2 & 2 & 2 & 23 & 5 & 5 & 4 & 5 & 4 & 4 & 1 & 4 & 4 & 4 & 40 \\
\hline 76 & 2 & 4 & 4 & 2 & 4 & 2 & 1 & 2 & 2 & 4 & 27 & 4 & 2 & 4 & 4 & 4 & 4 & 2 & 4 & 4 & 4 & 36 \\
\hline 77 & 1 & 4 & 4 & 2 & 4 & 2 & 1 & 2 & 2 & 4 & 26 & 4 & 2 & 4 & 4 & 5 & 4 & 2 & 4 & 4 & 4 & 37 \\
\hline 78 & 1 & 4 & 5 & 4 & 4 & 3 & 1 & 2 & 2 & 3 & 29 & 4 & 4 & 4 & 4 & 4 & 5 & 3 & 4 & 5 & 5 & 42 \\
\hline 79 & 1 & 4 & 5 & 4 & 4 & 3 & 1 & 2 & 2 & 3 & 29 & 4 & 3 & 5 & 5 & 5 & 5 & 3 & 4 & 5 & 5 & 44 \\
\hline 80 & 2 & 2 & 3 & 2 & 4 & 2 & 2 & 4 & 4 & 3 & 28 & 4 & 4 & 4 & 4 & 4 & 4 & 3 & 4 & 4 & 4 & 39 \\
\hline 81 & 2 & 4 & 5 & 2 & 4 & 2 & 1 & 2 & 1 & 4 & 27 & 4 & 2 & 4 & 4 & 4 & 4 & 2 & 5 & 4 & 4 & 37 \\
\hline 82 & 3 & 4 & 4 & 4 & 4 & 4 & 2 & 4 & 2 & 2 & 33 & 4 & 4 & 4 & 4 & 5 & 4 & 3 & 4 & 4 & 5 & 41 \\
\hline & & & & & & & & & & & & & & & \\
\hline
\end{tabular}




\begin{tabular}{|l|r|r|r|r|r|r|r|r|r|r|r|r|r|r|r|r|r|r|r|r|r|r|}
\hline Subjek & \multicolumn{10}{|c|}{ Butir Relativisme } & \multicolumn{10}{|c|}{ Butir Idealisme } \\
\hline & 1 & 2 & 3 & 4 & 5 & 6 & 7 & 8 & 9 & 10 & Total & 1 & 2 & 3 & 4 & 5 & 6 & 7 & 8 & 9 & 10 & Total \\
\hline 83 & 3 & 4 & 4 & 4 & 4 & 4 & 2 & 4 & 2 & 2 & 33 & 4 & 4 & 3 & 5 & 4 & 4 & 3 & 4 & 4 & 5 & 40 \\
\hline 84 & 2 & 4 & 4 & 4 & 2 & 4 & 2 & 4 & 2 & 2 & 30 & 2 & 4 & 5 & 5 & 5 & 5 & 2 & 3 & 5 & 5 & 41 \\
\hline 85 & 2 & 4 & 4 & 4 & 2 & 4 & 4 & 3 & 2 & 2 & 31 & 4 & 3 & 4 & 4 & 4 & 4 & 3 & 4 & 4 & 4 & 38 \\
\hline 86 & 3 & 4 & 3 & 3 & 3 & 4 & 3 & 3 & 3 & 4 & 33 & 4 & 3 & 5 & 4 & 4 & 4 & 1 & 3 & 4 & 1 & 33 \\
\hline 87 & 3 & 4 & 4 & 4 & 3 & 4 & 3 & 3 & 3 & 3 & 34 & 4 & 2 & 3 & 4 & 4 & 4 & 3 & 3 & 2 & 4 & 33 \\
\hline 88 & 2 & 4 & 3 & 3 & 3 & 4 & 4 & 3 & 4 & 3 & 33 & 4 & 1 & 4 & 4 & 4 & 1 & 4 & 4 & 3 & 4 & 33 \\
\hline 89 & 1 & 5 & 4 & 4 & 3 & 2 & 2 & 5 & 4 & 3 & 33 & 4 & 3 & 5 & 5 & 5 & 4 & 4 & 5 & 5 & 4 & 44 \\
\hline 90 & 2 & 4 & 4 & 4 & 4 & 4 & 4 & 4 & 4 & 4 & 38 & 5 & 4 & 4 & 5 & 5 & 5 & 4 & 4 & 4 & 5 & 45 \\
\hline 91 & 2 & 3 & 4 & 4 & 3 & 2 & 2 & 1 & 2 & 2 & 25 & 4 & 5 & 4 & 4 & 4 & 4 & 4 & 4 & 4 & 5 & 42 \\
\hline 92 & 2 & 4 & 4 & 4 & 3 & 3 & 4 & 3 & 4 & 3 & 34 & 4 & 2 & 2 & 3 & 3 & 3 & 3 & 3 & 3 & 2 & 28 \\
\hline 93 & 5 & 5 & 5 & 5 & 5 & 5 & 5 & 1 & 4 & 4 & 44 & 5 & 3 & 3 & 4 & 5 & 5 & 1 & 3 & 5 & 4 & 38 \\
\hline 94 & 2 & 4 & 4 & 3 & 5 & 3 & 2 & 4 & 4 & 1 & 32 & 4 & 2 & 4 & 5 & 5 & 4 & 2 & 2 & 4 & 2 & 34 \\
\hline 95 & 2 & 4 & 4 & 4 & 2 & 2 & 2 & 3 & 4 & 4 & 31 & 4 & 4 & 4 & 4 & 4 & 4 & 2 & 3 & 4 & 4 & 37 \\
\hline 96 & 4 & 4 & 4 & 4 & 4 & 4 & 4 & 4 & 4 & 4 & 40 & 4 & 4 & 4 & 4 & 4 & 4 & 4 & 2 & 4 & 2 & 36 \\
\hline 97 & 3 & 4 & 4 & 4 & 4 & 4 & 3 & 4 & 4 & 4 & 38 & 4 & 2 & 3 & 2 & 3 & 4 & 2 & 3 & 3 & 4 & 30 \\
\hline 98 & 4 & 4 & 3 & 2 & 4 & 4 & 3 & 4 & 4 & 5 & 37 & 4 & 4 & 4 & 4 & 4 & 4 & 4 & 4 & 4 & 4 & 40 \\
\hline 99 & 2 & 3 & 3 & 4 & 4 & 4 & 3 & 4 & 4 & 2 & 33 & 4 & 3 & 4 & 4 & 4 & 4 & 3 & 3 & 4 & 3 & 36 \\
\hline 100 & 3 & 4 & 4 & 4 & 4 & 2 & 2 & 3 & 4 & 3 & 33 & 2 & 4 & 4 & 4 & 4 & 2 & 4 & 4 & 4 & 4 & 36 \\
\hline 101 & 1 & 4 & 4 & 4 & 2 & 2 & 2 & 2 & 4 & 4 & 29 & 4 & 4 & 4 & 4 & 4 & 4 & 2 & 3 & 4 & 4 & 37 \\
\hline 102 & 2 & 4 & 4 & 3 & 4 & 4 & 2 & 4 & 4 & 3 & 34 & 4 & 4 & 4 & 5 & 5 & 4 & 3 & 4 & 4 & 5 & 42 \\
\hline 103 & 2 & 4 & 4 & 4 & 5 & 5 & 3 & 4 & 3 & 4 & 38 & 4 & 2 & 2 & 4 & 4 & 5 & 2 & 4 & 5 & 4 & 36 \\
\hline 104 & 3 & 4 & 4 & 4 & 4 & 4 & 3 & 2 & 2 & 2 & 32 & 4 & 4 & 4 & 4 & 4 & 4 & 4 & 4 & 4 & 4 & 40 \\
\hline & & & & & & & & & & & & & \\
\hline
\end{tabular}




\begin{tabular}{|r|r|r|r|r|r|r|r|r|r|r|r|r|r|r|r|r|r|r|r|r|r|r|}
\hline Subjek & \multicolumn{10}{|c|}{ Butir Relativisme } \\
\hline & 1 & 2 & 3 & 4 & 5 & 6 & 7 & 8 & 9 & 10 & Total & 1 & 2 & 3 & 4 & 5 & 6 & 7 & 8 & 9 & 10 & Total \\
\hline 105 & 2 & 4 & 4 & 4 & 4 & 4 & 4 & 4 & 4 & 4 & 38 & 4 & 4 & 4 & 4 & 4 & 4 & 4 & 4 & 4 & 4 & 40 \\
\hline 106 & 4 & 4 & 4 & 4 & 4 & 4 & 3 & 4 & 4 & 4 & 39 & 4 & 3 & 4 & 4 & 4 & 4 & 4 & 4 & 4 & 4 & 39 \\
\hline 107 & 2 & 4 & 4 & 4 & 4 & 4 & 4 & 3 & 4 & 2 & 35 & 4 & 3 & 4 & 4 & 4 & 5 & 4 & 3 & 4 & 4 & 39 \\
\hline 108 & 2 & 3 & 3 & 4 & 4 & 3 & 3 & 3 & 3 & 3 & 31 & 1 & 4 & 4 & 4 & 4 & 4 & 2 & 4 & 2 & 4 & 33 \\
\hline 109 & 3 & 3 & 4 & 4 & 4 & 4 & 4 & 4 & 4 & 4 & 38 & 4 & 3 & 4 & 5 & 5 & 4 & 3 & 3 & 4 & 4 & 39 \\
\hline 110 & 2 & 5 & 2 & 2 & 2 & 4 & 2 & 2 & 3 & 3 & 27 & 5 & 3 & 4 & 5 & 5 & 5 & 1 & 5 & 5 & 5 & 43 \\
\hline 111 & 3 & 3 & 4 & 4 & 5 & 3 & 2 & 3 & 3 & 4 & 34 & 4 & 3 & 4 & 5 & 5 & 3 & 3 & 3 & 1 & 4 & 35 \\
\hline 112 & 3 & 3 & 2 & 4 & 4 & 3 & 4 & 4 & 4 & 3 & 34 & 4 & 3 & 4 & 4 & 4 & 3 & 3 & 4 & 4 & 4 & 37 \\
\hline 113 & 4 & 4 & 4 & 4 & 4 & 3 & 3 & 4 & 2 & 3 & 35 & 1 & 4 & 4 & 4 & 4 & 4 & 2 & 4 & 2 & 4 & 33 \\
\hline 114 & 2 & 3 & 1 & 4 & 4 & 4 & 3 & 3 & 4 & 4 & 32 & 4 & 3 & 4 & 4 & 4 & 4 & 3 & 4 & 4 & 4 & 38 \\
\hline 115 & 4 & 5 & 4 & 4 & 4 & 5 & 1 & 3 & 4 & 4 & 38 & 5 & 2 & 5 & 5 & 5 & 5 & 4 & 5 & 5 & 5 & 46 \\
\hline 116 & 3 & 4 & 4 & 3 & 4 & 4 & 3 & 5 & 4 & 3 & 37 & 4 & 3 & 4 & 4 & 3 & 4 & 3 & 3 & 4 & 4 & 36 \\
\hline 117 & 2 & 4 & 4 & 4 & 4 & 3 & 3 & 4 & 4 & 4 & 36 & 4 & 3 & 4 & 5 & 5 & 4 & 3 & 3 & 4 & 4 & 39 \\
\hline 118 & 3 & 4 & 2 & 3 & 2 & 2 & 2 & 3 & 2 & 1 & 24 & 5 & 4 & 5 & 5 & 5 & 5 & 3 & 4 & 4 & 5 & 45 \\
\hline 119 & 2 & 3 & 3 & 3 & 3 & 3 & 2 & 4 & 2 & 3 & 28 & 5 & 4 & 4 & 4 & 4 & 5 & 2 & 4 & 4 & 5 & 41 \\
\hline 120 & 2 & 4 & 4 & 3 & 2 & 2 & 2 & 4 & 2 & 4 & 29 & 4 & 2 & 4 & 4 & 4 & 4 & 3 & 3 & 4 & 3 & 35 \\
\hline 121 & 2 & 5 & 5 & 3 & 4 & 4 & 2 & 3 & 3 & 4 & 35 & 5 & 2 & 3 & 5 & 5 & 4 & 3 & 4 & 4 & 3 & 38 \\
\hline 122 & 1 & 5 & 2 & 3 & 2 & 2 & 3 & 4 & 4 & 4 & 30 & 4 & 4 & 5 & 4 & 4 & 5 & 4 & 4 & 4 & 5 & 43 \\
\hline 123 & 3 & 4 & 4 & 5 & 4 & 3 & 3 & 4 & 1 & 4 & 35 & 4 & 4 & 4 & 5 & 4 & 5 & 4 & 4 & 5 & 4 & 43 \\
\hline 124 & 2 & 2 & 3 & 2 & 3 & 3 & 2 & 3 & 4 & 4 & 28 & 4 & 4 & 4 & 5 & 4 & 3 & 3 & 3 & 4 & 5 & 39 \\
\hline 125 & 2 & 4 & 3 & 4 & 2 & 3 & 2 & 2 & 2 & 2 & 26 & 4 & 3 & 4 & 4 & 4 & 4 & 3 & 4 & 4 & 4 & 38 \\
\hline 126 & 2 & 4 & 4 & 3 & 3 & 4 & 4 & 3 & 4 & 4 & 35 & 5 & 3 & 5 & 5 & 4 & 4 & 3 & 5 & 4 & 5 & 43 \\
\hline
\end{tabular}




\begin{tabular}{|c|c|c|c|c|c|c|c|c|c|c|c|c|c|c|c|c|c|c|c|c|c|c|}
\hline Subjek & \multicolumn{11}{|c|}{ Butir Relativisme } & \multicolumn{11}{|c|}{ Butir Idealisme } \\
\hline & 1 & 2 & 3 & 4 & 5 & 6 & 7 & 8 & 9 & 10 & Total & 1 & 2 & 3 & 4 & 5 & 6 & 7 & 8 & 9 & 10 & Tota \\
\hline 127 & 3 & 4 & 5 & 3 & 4 & 5 & 2 & 3 & 4 & 4 & 37 & 4 & 1 & 2 & 5 & 5 & 5 & 5 & 5 & 5 & 5 & 42 \\
\hline 128 & 3 & 3 & 4 & 4 & 5 & 5 & 3 & 3 & 3 & 4 & 37 & 5 & 5 & 5 & 5 & 5 & 5 & 4 & 5 & 5 & 5 & 49 \\
\hline 129 & 2 & 2 & 2 & 2 & 2 & 3 & 2 & 3 & 2 & 3 & 23 & 2 & 2 & 4 & 4 & 4 & 4 & 3 & 4 & 4 & 3 & 34 \\
\hline 130 & 3 & 4 & 4 & 4 & 4 & 4 & 2 & 2 & 3 & 3 & 33 & 4 & 4 & 4 & 5 & 5 & 5 & 3 & 3 & 3 & 4 & 40 \\
\hline 131 & 3 & 4 & 4 & 2 & 2 & 2 & 3 & 4 & 3 & 3 & 30 & 4 & 3 & 4 & 4 & 3 & 4 & 3 & 3 & 4 & 4 & 36 \\
\hline 132 & 2 & 4 & 4 & 4 & 2 & 3 & 3 & 2 & 4 & 4 & 32 & 4 & 2 & 3 & 2 & 3 & 4 & 2 & 3 & 3 & 4 & 30 \\
\hline 133 & 1 & 3 & 4 & 4 & 2 & 4 & 3 & 4 & 3 & 3 & 31 & 5 & 2 & 3 & 5 & 5 & 4 & 3 & 4 & 4 & 4 & 39 \\
\hline 134 & 2 & 3 & 4 & 4 & 4 & 3 & 4 & 3 & 2 & 2 & 31 & 5 & 4 & 4 & 4 & 4 & 5 & 2 & 4 & 4 & 5 & 41 \\
\hline 135 & 2 & 4 & 4 & 3 & 4 & 4 & 2 & 4 & 4 & 4 & 35 & 4 & 4 & 4 & 4 & 4 & 4 & 4 & 4 & 4 & 4 & 40 \\
\hline 136 & 3 & 5 & 5 & 5 & 5 & 5 & 5 & 4 & 1 & 1 & 39 & 4 & 1 & 2 & 5 & 5 & 5 & 5 & 5 & 5 & 5 & 42 \\
\hline 137 & 3 & 4 & 4 & 3 & 3 & 4 & 2 & 4 & 3 & 2 & 32 & 4 & 2 & 4 & 5 & 5 & 5 & 3 & 3 & 4 & 4 & 39 \\
\hline 138 & 2 & 4 & 4 & 2 & 2 & 4 & 4 & 3 & 2 & 2 & 29 & 1 & 4 & 4 & 4 & 4 & 4 & 2 & 4 & 2 & 4 & 33 \\
\hline 139 & 2 & 4 & 4 & 3 & 3 & 4 & 3 & 2 & 3 & 3 & 31 & 4 & 3 & 3 & 4 & 4 & 4 & 3 & 4 & 4 & 4 & 37 \\
\hline 140 & 2 & 3 & 3 & 4 & 4 & 3 & 4 & 3 & 2 & 2 & 30 & 4 & 4 & 4 & 4 & 4 & 4 & 4 & 4 & 4 & 4 & 40 \\
\hline 141 & 1 & 4 & 4 & 3 & 4 & 3 & 2 & 4 & 4 & 4 & 33 & 4 & 2 & 2 & 4 & 5 & 3 & 2 & 5 & 4 & 3 & 34 \\
\hline
\end{tabular}


Tabel 3. Manipulation Check

KASUS TIDAK ADA ASIMETRI INFORMASI

\begin{tabular}{|c|c|c|c|c|c|c|c|}
\hline \multirow[b]{2}{*}{ No. } & \multirow[b]{2}{*}{ Umur } & \multirow[b]{2}{*}{ Gender } & \multirow[b]{2}{*}{ IPK } & \multicolumn{2}{|c|}{$\begin{array}{c}\text { Manipulation Check } \\
\text { (8 soal) }\end{array}$} & \multirow{2}{*}{$\begin{array}{c}\% \\
\text { Kebenaran }\end{array}$} & \multirow[b]{2}{*}{ Ket } \\
\hline & & & & $\begin{array}{c}\text { Jawaban } \\
\text { yang } \\
\text { Benar }\end{array}$ & $\begin{array}{c}\text { Jawaban } \\
\text { yang } \\
\text { Salah } \\
\end{array}$ & & \\
\hline 1 & 21 & Perempuan & $3,26-3,50$ & 8 & 0 & 100 & Lolos \\
\hline 2 & 20 & Perempuan & $>3,51$ & 8 & 0 & 100 & Lolos \\
\hline 3 & 20 & Perempuan & $3,00-3,25$ & 8 & 0 & 100 & Lolos \\
\hline 4 & 21 & Perempuan & $>3,51$ & 8 & 0 & 100 & Lolos \\
\hline 5 & 20 & Perempuan & $3,26-3,50$ & 8 & 0 & 100 & Lolos \\
\hline 6 & 21 & Laki-Laki & $3,00-3,25$ & 8 & 0 & 100 & Lolos \\
\hline 7 & 20 & Perempuan & $>3,51$ & 8 & 0 & 100 & Lolos \\
\hline 8 & 20 & Perempuan & $>3,51$ & 8 & 0 & 100 & Lolos \\
\hline 9 & 21 & Laki-Laki & $3,00-3,25$ & 8 & 0 & 100 & Lolos \\
\hline 10 & 20 & Perempuan & $3,26-3,50$ & 6 & 2 & 75 & $\begin{array}{l}\text { Tidak } \\
\text { Lolos }\end{array}$ \\
\hline 11 & 20 & Perempuan & $3,26-3,50$ & 8 & 0 & 100 & Lolos \\
\hline 12 & 22 & Perempuan & $3,26-3,50$ & 7 & 1 & 88 & $\begin{array}{l}\text { Tidak } \\
\text { Lolos } \\
\end{array}$ \\
\hline 13 & 20 & Perempuan & $>3,51$ & 8 & 0 & 100 & Lolos \\
\hline 14 & 20 & Perempuan & $>3,51$ & 8 & 0 & 100 & Lolos \\
\hline 15 & 20 & Laki-Laki & $3,26-3,50$ & 8 & 0 & 100 & Lolos \\
\hline 16 & 21 & Perempuan & $3,26-3,50$ & 8 & 0 & 100 & Lolos \\
\hline 17 & 20 & Perempuan & $>3,51$ & 8 & 0 & 100 & Lolos \\
\hline 18 & 21 & Perempuan & $>3,51$ & 8 & 0 & 100 & Lolos \\
\hline 19 & 21 & Perempuan & $>3,51$ & 8 & 0 & 100 & Lolos \\
\hline 20 & 21 & Perempuan & $>3,51$ & 8 & 0 & 100 & Lolos \\
\hline 21 & 21 & Perempuan & $>3,51$ & 5 & 3 & 63 & $\begin{array}{l}\text { Tidak } \\
\text { Lolos } \\
\end{array}$ \\
\hline 22 & 20 & Perempuan & $>3,51$ & 8 & 0 & 100 & Lolos \\
\hline 23 & 20 & Perempuan & $3,00-3,25$ & 8 & 0 & 100 & Lolos \\
\hline 24 & 21 & Laki-Laki & $3,26-3,50$ & 8 & 0 & 100 & Lolos \\
\hline 25 & 21 & Laki-Laki & $>3,51$ & 8 & 0 & 100 & Lolos \\
\hline 26 & 20 & Perempuan & $>3,51$ & 7 & 1 & 88 & $\begin{array}{l}\text { Tidak } \\
\text { Lolos }\end{array}$ \\
\hline 27 & 21 & Perempuan & $>3,51$ & 7 & 1 & 88 & $\begin{array}{l}\text { Tidak } \\
\text { Lolos } \\
\end{array}$ \\
\hline 28 & 22 & Laki-Laki & $3,00-3,25$ & 8 & 0 & 100 & Lolos \\
\hline 29 & 21 & Perempuan & $>3,51$ & 8 & 0 & 100 & Lolos \\
\hline 30 & 22 & Laki-Laki & $3,26-3,50$ & 8 & 0 & 100 & Lolos \\
\hline
\end{tabular}




\begin{tabular}{|c|c|c|c|c|c|c|c|}
\hline \multirow[b]{2}{*}{ No. } & \multirow[b]{2}{*}{ Umur } & \multirow[b]{2}{*}{ Gender } & \multirow[b]{2}{*}{ IPK } & \multicolumn{2}{|c|}{$\begin{array}{c}\text { Manipulation Check } \\
(8 \text { soal })\end{array}$} & \multirow{2}{*}{$\begin{array}{c}\% \\
\text { Kebenaran }\end{array}$} & \multirow[b]{2}{*}{ Ket } \\
\hline & & & & $\begin{array}{c}\text { Jawaban } \\
\text { yang } \\
\text { Benar } \\
\end{array}$ & $\begin{array}{c}\text { Jawaban } \\
\text { yang } \\
\text { Salah } \\
\end{array}$ & & \\
\hline 31 & 21 & Perempuan & $>3,51$ & 8 & 0 & 100 & Lolos \\
\hline 32 & 21 & Perempuan & $>3,51$ & 8 & 0 & 100 & Lolos \\
\hline 33 & 21 & Perempuan & $3,26-3,50$ & 8 & 0 & 100 & Lolos \\
\hline 34 & 20 & Perempuan & $3,26-3,50$ & 5 & 3 & 63 & $\begin{array}{l}\text { Tidak } \\
\text { Lolos } \\
\end{array}$ \\
\hline 35 & 21 & Laki-Laki & $3,00-3,25$ & 8 & 0 & 100 & Lolos \\
\hline 36 & 21 & Laki-Laki & $3,26-3,50$ & 8 & 0 & 100 & Lolos \\
\hline 37 & 22 & Laki-Laki & $3,00-3,25$ & 8 & 0 & 100 & Lolos \\
\hline 38 & 22 & Perempuan & $>3,51$ & 8 & 0 & 100 & Lolos \\
\hline 39 & 21 & Laki-Laki & $>3,51$ & 7 & 1 & 88 & $\begin{array}{l}\text { Tidak } \\
\text { Lolos } \\
\end{array}$ \\
\hline 40 & 22 & Perempuan & $3,26-3,50$ & 8 & 0 & 100 & Lolos \\
\hline 41 & 20 & Laki-Laki & $3,00-3,25$ & 8 & 0 & 100 & Lolos \\
\hline 42 & 21 & Perempuan & $>3,51$ & 6 & 2 & 75 & $\begin{array}{l}\text { Tidak } \\
\text { Lolos } \\
\end{array}$ \\
\hline 43 & 20 & Perempuan & $>3,51$ & 8 & 0 & 100 & Lolos \\
\hline 44 & 20 & Perempuan & $>3,51$ & 8 & 0 & 100 & Lolos \\
\hline 45 & 20 & Perempuan & $>3,51$ & 8 & 0 & 100 & Lolos \\
\hline 46 & 21 & Perempuan & $3,26-3,50$ & 7 & 1 & 88 & $\begin{array}{l}\text { Tidak } \\
\text { Lolos }\end{array}$ \\
\hline
\end{tabular}

\section{KASUS ASIMETRI INFORMASI RENDAH}

\begin{tabular}{|c|c|c|c|c|c|c|c|}
\hline \multirow[b]{2}{*}{ No. } & \multirow[b]{2}{*}{ Umur } & \multirow[b]{2}{*}{ Gender } & \multirow[b]{2}{*}{ IPK } & \multicolumn{2}{|c|}{$\begin{array}{c}\text { Manipulation Check } \\
(8 \text { soal })\end{array}$} & \multirow{2}{*}{$\begin{array}{c}\% \\
\text { Kebenaran }\end{array}$} & \multirow[b]{2}{*}{ Ket } \\
\hline & & & & $\begin{array}{c}\text { Jawaban } \\
\text { yang } \\
\text { Benar }\end{array}$ & $\begin{array}{c}\text { Jawaban } \\
\text { yang } \\
\text { Salah }\end{array}$ & & \\
\hline 47 & 21 & Laki-Laki & $3,00-3,25$ & 5 & 3 & 63 & $\begin{array}{l}\text { Tidak } \\
\text { Lolos }\end{array}$ \\
\hline 48 & 22 & Perempuan & $3,26-3,50$ & 8 & 0 & 100 & Lolos \\
\hline 49 & 20 & Perempuan & $>3,51$ & 8 & 0 & 100 & Lolos \\
\hline 50 & 21 & Laki-Laki & $3,26-3,50$ & 8 & 0 & 100 & Lolos \\
\hline 51 & 21 & Laki-Laki & $3,00-3,25$ & 5 & 3 & 63 & $\begin{array}{l}\text { Tidak } \\
\text { Lolos }\end{array}$ \\
\hline 52 & 20 & Perempuan & $>3,51$ & 5 & 3 & 63 & $\begin{array}{l}\text { Tidak } \\
\text { Lolos }\end{array}$ \\
\hline 53 & 20 & Laki-Laki & $3,26-3,50$ & 8 & 0 & 100 & Lolos \\
\hline 54 & 21 & Laki-Laki & $>3,51$ & 8 & 0 & 100 & Lolos \\
\hline 55 & 21 & Laki-Laki & $3,26-3,50$ & 8 & 0 & 100 & Lolos \\
\hline
\end{tabular}




\begin{tabular}{|c|c|c|c|c|c|c|c|}
\hline \multirow[b]{2}{*}{ No. } & \multirow[b]{2}{*}{ Umur } & \multirow[b]{2}{*}{ Gender } & \multirow[b]{2}{*}{ IPK } & \multicolumn{2}{|c|}{$\begin{array}{c}\text { Manipulation Check } \\
(8 \text { soal })\end{array}$} & \multirow{2}{*}{$\begin{array}{c}\% \\
\text { Kebenaran }\end{array}$} & \multirow[b]{2}{*}{ Ket } \\
\hline & & & & $\begin{array}{c}\text { Jawaban } \\
\text { yang } \\
\text { Benar }\end{array}$ & $\begin{array}{c}\text { Jawaban } \\
\text { yang } \\
\text { Salah }\end{array}$ & & \\
\hline 56 & 21 & Perempuan & $3,26-3,50$ & 8 & 0 & 100 & Lolos \\
\hline 57 & 21 & Laki-Laki & $3,00-3,25$ & 6 & 2 & 75 & $\begin{array}{l}\text { Tidak } \\
\text { Lolos } \\
\end{array}$ \\
\hline 58 & 21 & Perempuan & $>3,51$ & 8 & 0 & 100 & Lolos \\
\hline 59 & 20 & Perempuan & $3,26-3,50$ & 8 & 0 & 100 & Lolos \\
\hline 60 & 21 & Perempuan & $3,00-3,25$ & 8 & 0 & 100 & Lolos \\
\hline 61 & 19 & Laki-Laki & $3,26-3,50$ & 8 & 0 & 100 & Lolos \\
\hline 62 & $>22$ & Perempuan & $>3,51$ & 8 & 0 & 100 & Lolos \\
\hline 63 & 21 & Perempuan & $>3,51$ & 8 & 0 & 100 & Lolos \\
\hline 64 & 20 & Perempuan & $>3,51$ & 8 & 0 & 100 & Lolos \\
\hline 65 & 21 & Laki-Laki & $3,00-3,25$ & 8 & 0 & 100 & Lolos \\
\hline 66 & 20 & Perempuan & $>3,51$ & 8 & 0 & 100 & Lolos \\
\hline 67 & 21 & Perempuan & $3,26-3,50$ & 6 & 2 & 75 & $\begin{array}{l}\text { Tidak } \\
\text { Lolos } \\
\end{array}$ \\
\hline 68 & 20 & Perempuan & $3,26-3,50$ & 6 & 2 & 75 & $\begin{array}{l}\text { Tidak } \\
\text { Lolos }\end{array}$ \\
\hline 69 & 21 & Laki-Laki & $3,26-3,50$ & 6 & 2 & 75 & $\begin{array}{l}\text { Tidak } \\
\text { Lolos } \\
\end{array}$ \\
\hline 70 & 22 & Perempuan & $>3,51$ & 8 & 0 & 100 & Lolos \\
\hline 71 & 21 & Laki-Laki & $3,00-3,25$ & 8 & 0 & 100 & Lolos \\
\hline 72 & 21 & Laki-Laki & $3,00-3,25$ & 8 & 0 & 100 & Lolos \\
\hline 73 & 21 & Perempuan & $3,26-3,50$ & 8 & 0 & 100 & Lolos \\
\hline 74 & 21 & Laki-Laki & $3,00-3,25$ & 8 & 0 & 100 & Lolos \\
\hline 75 & $>22$ & Laki-Laki & $3,26-3,50$ & 6 & 2 & 75 & $\begin{array}{l}\text { Tidak } \\
\text { Lolos }\end{array}$ \\
\hline 76 & 20 & Perempuan & $>3,51$ & 4 & 4 & 50 & $\begin{array}{l}\text { Tidak } \\
\text { Lolos } \\
\end{array}$ \\
\hline 77 & 20 & Perempuan & $3,26-3,50$ & 8 & 0 & 100 & Lolos \\
\hline 78 & 20 & Perempuan & $3,00-3,25$ & 8 & 0 & 100 & Lolos \\
\hline 79 & 21 & Laki-Laki & $3,00-3,25$ & 8 & 0 & 100 & Lolos \\
\hline 80 & 21 & Perempuan & $3,00-3,25$ & 8 & 0 & 100 & Lolos \\
\hline 81 & 20 & Perempuan & $3,26-3,50$ & 5 & 3 & 63 & $\begin{array}{l}\text { Tidak } \\
\text { Lolos } \\
\end{array}$ \\
\hline 82 & 20 & Perempuan & $3,26-3,50$ & 8 & 0 & 100 & Lolos \\
\hline 83 & 20 & Perempuan & $3,00-3,25$ & 6 & 2 & 75 & $\begin{array}{l}\text { Tidak } \\
\text { Lolos } \\
\end{array}$ \\
\hline 84 & 20 & Laki-Laki & $3,00-3,25$ & 8 & 0 & 100 & Lolos \\
\hline 85 & 21 & Laki-Laki & $3,26-3,50$ & 8 & 0 & 100 & Lolos \\
\hline 86 & 21 & Laki-Laki & $3,00-3,25$ & 8 & 0 & 100 & Lolos \\
\hline
\end{tabular}




\begin{tabular}{|c|c|c|c|c|c|c|c|}
\hline \multirow[b]{2}{*}{ No. } & \multirow[b]{2}{*}{ Umur } & \multirow[b]{2}{*}{ Gender } & \multirow[b]{2}{*}{ IPK } & \multicolumn{2}{|c|}{$\begin{array}{c}\text { Manipulation Check } \\
(8 \text { soal })\end{array}$} & \multirow{2}{*}{$\begin{array}{c}\% \\
\text { Kebenaran }\end{array}$} & \multirow[b]{2}{*}{ Ket } \\
\hline & & & & $\begin{array}{c}\text { Jawaban } \\
\text { yang } \\
\text { Benar }\end{array}$ & $\begin{array}{c}\text { Jawaban } \\
\text { yang } \\
\text { Salah }\end{array}$ & & \\
\hline 87 & 21 & Laki-Laki & $3,00-3,25$ & 4 & 4 & 50 & $\begin{array}{l}\text { Tidak } \\
\text { Lolos } \\
\end{array}$ \\
\hline 88 & 20 & Perempuan & $3,26-3,50$ & 8 & 0 & 100 & Lolos \\
\hline 89 & 21 & Laki-Laki & $>3,51$ & 5 & 3 & 63 & $\begin{array}{l}\text { Tidak } \\
\text { Lolos }\end{array}$ \\
\hline 90 & 20 & Perempuan & $3,26-3,50$ & 8 & 0 & 100 & Lolos \\
\hline 91 & 21 & Laki-Laki & $3,26-3,50$ & 8 & 0 & 100 & Lolos \\
\hline 92 & 20 & Perempuan & $3,00-3,25$ & 8 & 0 & 100 & Lolos \\
\hline 93 & 20 & Laki-Laki & $3,00-3,25$ & 6 & 2 & 75 & $\begin{array}{l}\text { Tidak } \\
\text { Lolos }\end{array}$ \\
\hline
\end{tabular}

KASUS ASIMETRI INFORMASI TINGGI

\begin{tabular}{|c|c|c|c|c|c|c|c|}
\hline \multirow[b]{2}{*}{ No. } & \multirow[b]{2}{*}{ Umur } & \multirow[b]{2}{*}{ Gender } & \multirow[b]{2}{*}{ IPK } & \multicolumn{2}{|c|}{$\begin{array}{c}\text { Manipulation Check } \\
\text { (8 soal) }\end{array}$} & \multirow{2}{*}{$\begin{array}{c}\% \\
\text { Kebenaran }\end{array}$} & \multirow[b]{2}{*}{ Ket } \\
\hline & & & & $\begin{array}{c}\text { Jawaban } \\
\text { yang } \\
\text { Benar }\end{array}$ & $\begin{array}{c}\text { Jawaban } \\
\text { yang } \\
\text { Salah }\end{array}$ & & \\
\hline 94 & 20 & Perempuan & $>3,51$ & 8 & 0 & 100 & Lolos \\
\hline 95 & 20 & Perempuan & $3,26-3,50$ & 8 & 0 & 100 & Lolos \\
\hline 96 & 22 & Laki-Laki & $>3,51$ & 6 & 2 & 75 & $\begin{array}{l}\text { Tidak } \\
\text { Lolos }\end{array}$ \\
\hline 97 & 21 & Laki-Laki & $3,26-3,50$ & 7 & 1 & 88 & $\begin{array}{l}\text { Tidak } \\
\text { Lolos }\end{array}$ \\
\hline 98 & 21 & Perempuan & $>3,51$ & 8 & 0 & 100 & Lolos \\
\hline 99 & 20 & Perempuan & $3,26-3,50$ & 8 & 0 & 100 & Lolos \\
\hline 100 & 20 & Perempuan & $3,00-3,25$ & 8 & 0 & 100 & Lolos \\
\hline 101 & 20 & Perempuan & $3,26-3,50$ & 8 & 0 & 100 & Lolos \\
\hline 102 & 22 & Perempuan & $>3,51$ & 8 & 0 & 100 & Lolos \\
\hline 103 & 21 & Perempuan & $3,26-3,50$ & 8 & 0 & 100 & Lolos \\
\hline 104 & 20 & Perempuan & $3,26-3,50$ & 8 & 0 & 100 & Lolos \\
\hline 105 & 20 & Perempuan & $3,26-3,50$ & 8 & 0 & 100 & Lolos \\
\hline 106 & 20 & Perempuan & $>3,51$ & 7 & 1 & 88 & $\begin{array}{l}\text { Tidak } \\
\text { Lolos }\end{array}$ \\
\hline 107 & 21 & Perempuan & $>3,51$ & 8 & 0 & 100 & Lolos \\
\hline 108 & 21 & Perempuan & $>3,51$ & 4 & 4 & 50 & $\begin{array}{l}\text { Tidak } \\
\text { Lolos }\end{array}$ \\
\hline 109 & 20 & Perempuan & $3,26-3,50$ & 8 & 0 & 100 & Lolos \\
\hline 110 & $>22$ & Perempuan & $>3,51$ & 5 & 3 & 63 & $\begin{array}{l}\text { Tidak } \\
\text { Lolos }\end{array}$ \\
\hline 111 & 21 & Perempuan & $>3,51$ & 8 & 0 & 100 & Lolos \\
\hline
\end{tabular}




\begin{tabular}{|c|c|c|c|c|c|c|c|}
\hline \multirow[b]{2}{*}{ No. } & \multirow[b]{2}{*}{ Umur } & \multirow[b]{2}{*}{ Gender } & \multirow[b]{2}{*}{ IPK } & \multicolumn{2}{|c|}{$\begin{array}{c}\text { Manipulation Check } \\
\text { (8 soal) }\end{array}$} & \multirow{2}{*}{$\begin{array}{c}\% \\
\text { Kebenaran }\end{array}$} & \multirow[b]{2}{*}{ Ket } \\
\hline & & & & $\begin{array}{c}\text { Jawaban } \\
\text { yang } \\
\text { Benar } \\
\end{array}$ & $\begin{array}{c}\text { Jawaban } \\
\text { yang } \\
\text { Salah } \\
\end{array}$ & & \\
\hline 112 & 22 & Perempuan & $>3,51$ & 8 & 0 & 100 & Lolos \\
\hline 113 & 21 & Laki-Laki & $3,26-3,50$ & 8 & 0 & 100 & Lolos \\
\hline 114 & 20 & Perempuan & $3,26-3,50$ & 8 & 0 & 100 & Lolos \\
\hline 115 & 21 & Laki-Laki & $3,26-3,50$ & 6 & 2 & 75 & $\begin{array}{l}\text { Tidak } \\
\text { Lolos } \\
\end{array}$ \\
\hline 116 & 20 & Perempuan & $>3,51$ & 8 & 0 & 100 & Lolos \\
\hline 117 & 22 & Perempuan & $>3,51$ & 6 & 2 & 75 & $\begin{array}{l}\text { Tidak } \\
\text { Lolos } \\
\end{array}$ \\
\hline 118 & 21 & Laki-Laki & $3,26-3,50$ & 8 & 0 & 100 & Lolos \\
\hline 119 & 20 & Perempuan & $3,26-3,50$ & 8 & 0 & 100 & Lolos \\
\hline 120 & 21 & Laki-Laki & $3,00-3,25$ & 8 & 0 & 100 & Lolos \\
\hline 121 & 21 & Perempuan & $3,26-3,50$ & 7 & 1 & 88 & $\begin{array}{l}\text { Tidak } \\
\text { Lolos } \\
\end{array}$ \\
\hline 122 & 19 & Laki-Laki & $3,26-3,50$ & 5 & 3 & 63 & $\begin{array}{l}\text { Tidak } \\
\text { Lolos } \\
\end{array}$ \\
\hline 123 & 20 & Perempuan & $3,26-3,50$ & 8 & 0 & 100 & Lolos \\
\hline 124 & 20 & Laki-Laki & $3,00-3,25$ & 8 & 0 & 100 & Lolos \\
\hline 125 & 21 & Laki-Laki & $<3,00$ & 8 & 0 & 100 & Lolos \\
\hline 126 & 21 & Perempuan & $3,26-3,50$ & 7 & 1 & 88 & $\begin{array}{l}\text { Tidak } \\
\text { Lolos } \\
\end{array}$ \\
\hline 127 & 22 & Perempuan & $>3,51$ & 8 & 0 & 100 & Lolos \\
\hline 128 & 20 & Laki-Laki & $3,26-3,50$ & 8 & 0 & 100 & Lolos \\
\hline 129 & 20 & Perempuan & $3,00-3,25$ & 8 & 0 & 100 & Lolos \\
\hline 130 & 21 & Laki-Laki & $3,00-3,25$ & 8 & 0 & 100 & Lolos \\
\hline 131 & 21 & Laki-Laki & $<3,00$ & 8 & 0 & 100 & Lolos \\
\hline 132 & 20 & Perempuan & $>3,51$ & 8 & 0 & 100 & Lolos \\
\hline 133 & 21 & Perempuan & $>3,51$ & 8 & 0 & 100 & Lolos \\
\hline 134 & 20 & Perempuan & $3,26-3,50$ & 8 & 0 & 100 & Lolos \\
\hline 135 & 21 & Perempuan & $>3,51$ & 6 & 2 & 75 & $\begin{array}{l}\text { Tidak } \\
\text { Lolos } \\
\end{array}$ \\
\hline 136 & 21 & Perempuan & $>3,51$ & 8 & 0 & 100 & Lolos \\
\hline 137 & 21 & Perempuan & $3,26-3,50$ & 8 & 0 & 100 & Lolos \\
\hline 138 & 21 & Perempuan & $3,26-3,50$ & 8 & 0 & 100 & Lolos \\
\hline 139 & 21 & Perempuan & $3,00-3,25$ & 8 & 0 & 100 & Lolos \\
\hline 140 & 21 & Perempuan & $3,26-3,50$ & 8 & 0 & 100 & Lolos \\
\hline 141 & 21 & Perempuan & $3,26-3,50$ & 8 & 0 & 100 & Lolos \\
\hline
\end{tabular}


Tabel 4. Statistik Deskriptif

\begin{tabular}{|c|c|c|c|c|c|}
\hline & $\mathrm{N}$ & Minimum & Maximum & Mean & $\begin{array}{c}\text { Std. } \\
\text { Deviation }\end{array}$ \\
\hline INF & 141 & 0 & 2 & 1.01 & .819 \\
\hline REL & 141 & 0 & 1 & .50 & .502 \\
\hline IDL & 141 & 0 & 1 & .54 & .500 \\
\hline NONE & 46 & .00 & .80 & 2464 & .23606 \\
\hline LOW & 47 & .00 & 1.00 & .4107 & .24634 \\
\hline HIGH & 48 & .00 & 1.00 & .5688 & .27855 \\
\hline PRODUKSI1 & 141 & 2 & 10 & 4.63 & 1.798 \\
\hline PRODUKSI2 & 141 & 2 & 10 & 5.64 & 1.913 \\
\hline PRODUKSI3 & 141 & 3 & 12 & 6.81 & 2.308 \\
\hline EXPPERFORMANCE & 141 & 2 & 10 & 5.13 & 1.809 \\
\hline TARGET & 141 & 1 & 11 & 4.78 & 2.188 \\
\hline KOMPENSASI & 141 & 10000 & 10700 & 10202.84 & 151.631 \\
\hline SLACK & 141 & .00 & 1.00 & .4109 & .28519 \\
\hline Valid N (listwise) & 46 & & & & \\
\hline
\end{tabular}

Tabel 5. Frekuensi Statistik Demografi Umur Kasus Tidak Ada Asimetri Informasi

\begin{tabular}{|c|c|c|c|c|c|}
\hline & & Frequency & Percent & $\begin{array}{c}\text { Valid } \\
\text { Percent }\end{array}$ & Cumulative Percent \\
\hline \multirow[t]{4}{*}{ Valid } & 20 & 19 & 41.3 & 41.3 & 41.3 \\
\hline & 21 & 21 & 45.7 & 45.7 & 87.0 \\
\hline & 22 & 6 & 13.0 & 13.0 & 100.0 \\
\hline & Total & 46 & 100.0 & 100.0 & \\
\hline
\end{tabular}


Tabel 6. Frekuensi Statistik Demografi Umur Kasus Asimetri Informasi Rendah

\begin{tabular}{|rl|r|r|r|r|}
\hline & & & & \\
& & Frequency & Percent & Palid \\
Percent & $\begin{array}{c}\text { Cumulative } \\
\text { Percent }\end{array}$ \\
\hline Valid & 19 & 2.1 & 2.1 & 2.1 \\
& 18 & 38.3 & 38.3 & 40.4 \\
& 18 & 24 & 51.1 & 51.1 & 91.5 \\
& 22 & 2 & 4.3 & 4.3 & 95.7 \\
& $>22$ & 2 & 4.3 & 4.3 & 100.0 \\
& Total & 47 & 100.0 & 100.0 & \\
\hline
\end{tabular}

Tabel 7. Frekuensi Statistik Demografi Umur Kasus Asimetri Informasi Tinggi

\begin{tabular}{|ll|r|r|r|r|}
\hline & & & Valid & \multicolumn{2}{|c|}{$\begin{array}{c}\text { Cumulative } \\
\text { Percent }\end{array}$} \\
\hline Valid & Frequency & Percent & Percent & 2.1 \\
& 19 & 2.1 & 2.1 & 4.2 \\
20 & 1 & 2.1 & 2.1 & 41.7 \\
21 & 18 & 37.5 & 37.5 & 89.6 \\
22 & 23 & 47.9 & 47.9 & 100.0 \\
Total & 5 & 10.4 & 10.4 & \\
\hline
\end{tabular}

Tabel 8. Frekuensi Statistik Demografi Gender Kasus Tidak Ada Asimetri Informasi

\begin{tabular}{|c|c|c|c|c|c|}
\hline & & Frequency & Percent & $\begin{array}{c}\text { Valid } \\
\text { Percent }\end{array}$ & $\begin{array}{c}\text { Cumulative } \\
\text { Percent }\end{array}$ \\
\hline \multirow[t]{3}{*}{ Valid } & Laki-Laki & 12 & 26.1 & 26.1 & 26.1 \\
\hline & Perempuan & 34 & 73.9 & 73.9 & 100.0 \\
\hline & Total & 46 & 100.0 & 100.0 & \\
\hline
\end{tabular}


Tabel 9. Frekuensi Statistik Demografi Gender KasusAsimetri Informasi Rendah

\begin{tabular}{|c|c|c|c|c|c|}
\hline & & Frequency & Percent & $\begin{array}{c}\text { Valid } \\
\text { Percent }\end{array}$ & $\begin{array}{c}\text { Cumulative } \\
\text { Percent }\end{array}$ \\
\hline \multirow[t]{3}{*}{ Valid } & Laki-Laki & 22 & 46.8 & 46.8 & 46.8 \\
\hline & Perempuan & 25 & 53.2 & 53.2 & 100.0 \\
\hline & Total & 47 & 100.0 & 100.0 & \\
\hline
\end{tabular}

Tabel 10. Frekuensi Statistik Demografi Gender Kasus Asimetri Informasi Tinggi

\begin{tabular}{|c|c|c|c|c|c|}
\hline & & Frequency & Percent & $\begin{array}{c}\text { Valid } \\
\text { Percent }\end{array}$ & $\begin{array}{c}\text { Cumulative } \\
\text { Percent }\end{array}$ \\
\hline \multirow[t]{3}{*}{ Valid } & Laki-Laki & 12 & 25.0 & 25.0 & 25.0 \\
\hline & Perempuan & 36 & 75.0 & 75.0 & 100.0 \\
\hline & Total & 48 & 100.0 & 100.0 & \\
\hline
\end{tabular}

Tabel 11. Frekuensi Statistik Demografi Angkatan Kasus Tidak Ada Asimetri Informasi

\begin{tabular}{|c|c|c|c|c|c|}
\hline & & Frequency & Percent & $\begin{array}{c}\text { Valid } \\
\text { Percent }\end{array}$ & $\begin{array}{c}\text { Cumulative } \\
\text { Percent }\end{array}$ \\
\hline \multirow[t]{3}{*}{ Valid } & 2010 & 8 & 17.4 & 17.4 & 17.4 \\
\hline & 2011 & 38 & 82.6 & 82.6 & 100.0 \\
\hline & Total & 46 & 100.0 & 100.0 & \\
\hline
\end{tabular}

Tabel 12. Frekuensi Statistik Demografi Angkatan Kasus Asimetri Informasi Rendah

\begin{tabular}{|c|c|c|c|c|c|}
\hline & & Frequency & Percent & $\begin{array}{c}\text { Valid } \\
\text { Percent }\end{array}$ & $\begin{array}{c}\text { Cumulative } \\
\text { Percent }\end{array}$ \\
\hline \multirow[t]{3}{*}{ Valic } & 2010 & 7 & 14.9 & 14.9 & 14.9 \\
\hline & 2011 & 40 & 85.1 & 85.1 & 100.0 \\
\hline & Total & 47 & 100.0 & 100.0 & \\
\hline
\end{tabular}


Tabel 13. Frekuensi Statistik Demografi Angkatan Kasus Asimetri Informasi Tinggi

\begin{tabular}{|c|c|c|c|c|c|}
\hline & & Frequency & Percent & $\begin{array}{c}\text { Valid } \\
\text { Percent }\end{array}$ & $\begin{array}{c}\text { Cumulative } \\
\text { Percent }\end{array}$ \\
\hline \multirow[t]{3}{*}{ Valid } & 2010 & 7 & 14.6 & 14.6 & 14.6 \\
\hline & 2011 & 41 & 85.4 & 85.4 & 100.0 \\
\hline & Total & 48 & 100.0 & 100.0 & \\
\hline
\end{tabular}

Tabel 14. Frekuensi Statistik Demografi IPK Kasus Tidak Ada Asimetri Informasi

\begin{tabular}{|c|c|c|c|c|c|}
\hline & & Frequency & Percent & $\begin{array}{c}\text { Valid } \\
\text { Percent }\end{array}$ & $\begin{array}{c}\text { Cumulative } \\
\text { Percent }\end{array}$ \\
\hline \multirow[t]{4}{*}{ Valid } & $>3,51$ & 24 & 52.2 & 52.2 & 52.2 \\
\hline & $3,00-3,25$ & 8 & 17.4 & 17.4 & 69.6 \\
\hline & $3,26-3,50$ & 14 & 30.4 & 30.4 & 100.0 \\
\hline & Total & 46 & 100.0 & 100.0 & \\
\hline
\end{tabular}

Tabel 15. Frekuensi Statistik Demografi IPK Kasus Asimetri Informasi Rendah

\begin{tabular}{|c|c|c|c|c|c|}
\hline & & Frequency & Percent & $\begin{array}{c}\text { Valid } \\
\text { Percent }\end{array}$ & $\begin{array}{l}\text { Cumulative } \\
\text { Percent }\end{array}$ \\
\hline \multirow[t]{4}{*}{ Valid } & $>3,51$ & 11 & 23.4 & 23.4 & 23.4 \\
\hline & $3,00-3,25$ & 17 & 36.2 & 36.2 & 59.6 \\
\hline & $3,26-3,50$ & 19 & 40.4 & 40.4 & 100.0 \\
\hline & Total & 47 & 100.0 & 100.0 & \\
\hline
\end{tabular}


Tabel 16. Frekuensi Statistik Demografi IPK Kasus Asimetri Informasi Tinggi

\begin{tabular}{|r|r|r|r|r|}
\hline & & & Valid \\
Percent & $\begin{array}{c}\text { Cumulative } \\
\text { Percent }\end{array}$ \\
\hline Valid $<3,00$ & 2 & 4.2 & 4.2 & 4.2 \\
& Frequency & Percent & 39.6 \\
3,51 & 17 & 35.4 & 35.4 & 52.1 \\
$3,00-3,25$ & 6 & 12.5 & 12.5 & 100.0 \\
Total & 23,50 & 47.9 & 47.9 & \\
\hline
\end{tabular}




\section{LAMPIRAN}

3 
Tabel 16. Uji Validitas Relativisme

\begin{tabular}{|c|c|c|c|c|c|c|c|c|c|c|c|c|}
\hline \multicolumn{13}{|c|}{ Correlations } \\
\hline & & REL1 & REL2 & REL3 & REL4 & REL5 & REL6 & REL7 & REL8 & REL9 & REL10 & $\begin{array}{c}\text { REL } \\
\text { TOTAL }\end{array}$ \\
\hline REL1 & $\begin{array}{l}\text { Pearson } \\
\text { Correlation }\end{array}$ & 1 & $.458^{*}$ & 0.108 & 0.142 & 0.099 & $.368^{*}$ & $.370^{*}$ & 0.347 & 0.261 & 0.232 & $.513^{* *}$ \\
\hline & $\begin{array}{l}\text { Sig. (2- } \\
\text { tailed) }\end{array}$ & & 0.011 & 0.571 & 0.454 & 0.604 & 0.045 & 0.044 & 0.06 & 0.164 & 0.216 & 0.004 \\
\hline & $\mathrm{N}$ & 30 & 30 & 30 & 30 & 30 & 30 & 30 & 30 & 30 & 30 & 30 \\
\hline REL2 & $\begin{array}{l}\text { Pearson } \\
\text { Correlation }\end{array}$ & $.458^{*}$ & 1 & 0.343 & 0.336 & $.387^{*}$ & $.738^{* *}$ & $.462^{*}$ & $.417^{*}$ & 0.334 & 0.298 & $.747^{* *}$ \\
\hline & $\begin{array}{l}\text { Sig. (2- } \\
\text { tailed) }\end{array}$ & 0.011 & & 0.064 & 0.07 & 0.035 & 0 & 0.01 & 0.022 & 0.072 & 0.11 & 0 \\
\hline & $\mathrm{N}$ & 30 & 30 & 30 & 30 & 30 & 30 & 30 & 30 & 30 & 30 & 30 \\
\hline
\end{tabular}




\begin{tabular}{|c|c|c|c|c|c|c|c|c|c|c|c|c|}
\hline REL3 & $\begin{array}{l}\text { Pearson } \\
\text { Correlation }\end{array}$ & 0.108 & 0.343 & 1 & $.620^{* *}$ & 0.327 & 0.326 & $.396^{*}$ & 0.123 & -0.011 & 0.096 & $.525^{* *}$ \\
\hline & $\begin{array}{l}\text { Sig. (2- } \\
\text { tailed) }\end{array}$ & 0.571 & 0.064 & & 0 & 0.078 & 0.078 & 0.03 & 0.518 & 0.956 & 0.613 & 0.003 \\
\hline & $\mathrm{N}$ & 30 & 30 & 30 & 30 & 30 & 30 & 30 & 30 & 30 & 30 & 30 \\
\hline REL4 & $\begin{array}{l}\text { Pearson } \\
\text { Correlation }\end{array}$ & 0.142 & 0.336 & $.620^{* *}$ & 1 & 0.04 & $.461^{*}$ & 0.262 & 0.085 & 0.137 & 0.193 & $.509^{* *}$ \\
\hline & $\begin{array}{l}\text { Sig. (2- } \\
\text { tailed) }\end{array}$ & 0.454 & 0.07 & 0 & & 0.832 & 0.01 & 0.162 & 0.656 & 0.471 & 0.307 & 0.004 \\
\hline & $\mathrm{N}$ & 30 & 30 & 30 & 30 & 30 & 30 & 30 & 30 & 30 & 30 & 30 \\
\hline REL5 & $\begin{array}{l}\text { Pearson } \\
\text { Correlation }\end{array}$ & 0.099 & $.387^{*}$ & 0.327 & 0.04 & 1 & $.491^{* *}$ & $.581^{* *}$ & 0.318 & 0.303 & 0.174 & $.592^{* * *}$ \\
\hline & $\begin{array}{l}\text { Sig. (2- } \\
\text { tailed) }\end{array}$ & 0.604 & 0.035 & 0.078 & 0.832 & & 0.006 & 0.001 & 0.087 & 0.103 & 0.358 & 0.001 \\
\hline & $\mathrm{N}$ & 30 & 30 & 30 & 30 & 30 & 30 & 30 & 30 & 30 & 30 & 30 \\
\hline
\end{tabular}




\begin{tabular}{|c|c|c|c|c|c|c|c|c|c|c|c|c|}
\hline REL6 & $\begin{array}{l}\text { Pearson } \\
\text { Correlation }\end{array}$ & $.368^{*}$ & $.738^{* *}$ & 0.326 & $.461^{*}$ & $.491^{* *}$ & 1 & $.544^{* *}$ & $.529^{* *}$ & $.541^{* *}$ & $.559^{* *}$ & $.867^{* *}$ \\
\hline & $\begin{array}{l}\text { Sig. (2- } \\
\text { tailed) }\end{array}$ & 0.045 & 0 & 0.078 & 0.01 & 0.006 & & 0.002 & 0.003 & 0.002 & 0.001 & 0 \\
\hline & $\mathrm{N}$ & 30 & 30 & 30 & 30 & 30 & 30 & 30 & 30 & 30 & 30 & 30 \\
\hline REL7 & $\begin{array}{l}\text { Pearson } \\
\text { Correlation }\end{array}$ & $.370^{*}$ & $.462^{*}$ & $.396^{*}$ & 0.262 & $.581^{* *}$ & $.544^{* *}$ & 1 & $.533^{* *}$ & $.440^{*}$ & 0.283 & $.760^{* * *}$ \\
\hline & $\begin{array}{l}\text { Sig. (2- } \\
\text { tailed) }\end{array}$ & 0.044 & 0.01 & 0.03 & 0.162 & 0.001 & 0.002 & & 0.002 & 0.015 & 0.13 & 0 \\
\hline & $\mathrm{N}$ & 30 & 30 & 30 & 30 & 30 & 30 & 30 & 30 & 30 & 30 & 30 \\
\hline REL8 & $\begin{array}{l}\text { Pearson } \\
\text { Correlation }\end{array}$ & 0.347 & $.417^{*}$ & 0.123 & 0.085 & 0.318 & $.529^{* *}$ & $.533^{* *}$ & 1 & $.432^{*}$ & 0.351 & $.645^{* *}$ \\
\hline & $\begin{array}{l}\text { Sig. (2- } \\
\text { tailed) }\end{array}$ & 0.06 & 0.022 & 0.518 & 0.656 & 0.087 & 0.003 & 0.002 & & 0.017 & 0.057 & 0 \\
\hline & $\mathrm{N}$ & 30 & 30 & 30 & 30 & 30 & 30 & 30 & 30 & 30 & 30 & 30 \\
\hline
\end{tabular}




\begin{tabular}{|c|c|c|c|c|c|c|c|c|c|c|c|c|}
\hline \multirow[t]{3}{*}{ REL9 } & $\begin{array}{l}\text { Pearson } \\
\text { Correlation }\end{array}$ & 0.261 & 0.334 & 0.011 & 0.137 & 0.303 & $.541^{* *}$ & $.440^{*}$ & $.432^{*}$ & 1 & $.739^{* *}$ & $.645^{* *}$ \\
\hline & $\begin{array}{l}\text { Sig. (2- } \\
\text { tailed) }\end{array}$ & 0.164 & 0.072 & 0.956 & 0.471 & 0.103 & 0.002 & 0.015 & 0.017 & & 0 & 0 \\
\hline & $\mathrm{N}$ & 30 & 30 & 30 & 30 & 30 & 30 & 30 & 30 & 30 & 30 & 30 \\
\hline \multirow[t]{3}{*}{$\begin{array}{l}\text { REL1 } \\
0\end{array}$} & $\begin{array}{l}\text { Pearson } \\
\text { Correlation }\end{array}$ & 0.232 & 0.298 & 0.096 & 0.193 & 0.174 & $.559^{* *}$ & 0.283 & 0.351 & $.739^{* *}$ & 1 & $.609^{* * *}$ \\
\hline & $\begin{array}{l}\text { Sig. (2- } \\
\text { tailed) }\end{array}$ & 0.216 & 0.11 & 0.613 & 0.307 & 0.358 & 0.001 & 0.13 & 0.057 & 0 & & 0 \\
\hline & $\mathrm{N}$ & 30 & 30 & 30 & 30 & 30 & 30 & 30 & 30 & 30 & 30 & 30 \\
\hline \multirow{3}{*}{$\begin{array}{l}\text { REL } \\
\text { TOT } \\
\text { AL }\end{array}$} & $\begin{array}{l}\text { Pearson } \\
\text { Correlation }\end{array}$ & $.513^{* *}$ & $.747^{* *}$ & $.525^{* *}$ & $.509^{* * *}$ & $.592^{* *}$ & $.867^{* *}$ & $.760^{* *}$ & $.645^{* *}$ & $.645^{* *}$ & $.609^{* * *}$ & 1 \\
\hline & $\begin{array}{l}\text { Sig. (2- } \\
\text { tailed) }\end{array}$ & 0.004 & 0 & 0.003 & 0.004 & 0.001 & 0 & 0 & 0 & 0 & 0 & \\
\hline & $\mathrm{N}$ & 30 & 30 & 30 & 30 & 30 & 30 & 30 & 30 & 30 & 30 & 30 \\
\hline
\end{tabular}


*. Correlation is significant at the 0.05 level (2-tailed).

**. Correlation is significant at the 0.01 level (2-tailed).

Tabel 17. Uji Validitas Idealisme

Correlations

\begin{tabular}{|c|c|c|c|c|c|c|c|c|c|c|c|c|}
\hline & & IDL1 & IDL2 & IDL3 & IDL4 & IDL5 & IDL6 & IDL7 & IDL8 & IDL9 & IDL10 & $\begin{array}{c}\text { IDL } \\
\text { SKOR }\end{array}$ \\
\hline \multirow[t]{3}{*}{ IDL1 } & $\begin{array}{l}\text { Pearson } \\
\text { Correlation }\end{array}$ & 1 & .178 & .171 & .180 & .032 & .351 & .266 & .223 & .069 & .139 & $.529^{* *}$ \\
\hline & $\begin{array}{l}\text { Sig. (2- } \\
\text { tailed) }\end{array}$ & & .346 & .366 & .341 & .866 & .058 & .155 & .236 & .715 & .465 & .003 \\
\hline & $\mathrm{N}$ & 30 & 30 & 30 & 30 & 30 & 30 & 30 & 30 & 30 & 30 & 30 \\
\hline \multirow[t]{3}{*}{ IDL2 } & $\begin{array}{l}\text { Pearson } \\
\text { Correlation }\end{array}$ & .178 & 1 & $.533^{* *}$ & .197 & -.075 & .226 & .337 & .125 & .350 & .245 & $.615^{* *}$ \\
\hline & $\begin{array}{l}\text { Sig. (2- } \\
\text { tailed) }\end{array}$ & .346 & & .002 & .296 & .694 & .231 & .069 & .512 & .058 & .192 & .000 \\
\hline & $\mathrm{N}$ & 30 & 30 & 30 & 30 & 30 & 30 & 30 & 30 & 30 & 30 & 30 \\
\hline \multirow[t]{3}{*}{ IDL3 } & $\begin{array}{l}\text { Pearson } \\
\text { Correlation }\end{array}$ & .171 & $.533^{* *}$ & 1 & .334 & .166 & $.484^{* *}$ & .044 & -.054 & $.498^{* *}$ & .302 & $.626^{* *}$ \\
\hline & $\begin{array}{l}\text { Sig. (2- } \\
\text { tailed) }\end{array}$ & .366 & .002 & & .071 & .382 & .007 & .818 & .776 & .005 & .105 & .000 \\
\hline & $\mathrm{N}$ & 30 & 30 & 30 & 30 & 30 & 30 & 30 & 30 & 30 & 30 & 30 \\
\hline \multirow[t]{2}{*}{ IDL4 } & $\begin{array}{l}\text { Pearson } \\
\text { Correlation }\end{array}$ & .180 & .197 & .334 & 1 & $.658^{* *}$ & .264 & .080 & .198 & $.461^{*}$ & .127 & $.573^{* *}$ \\
\hline & Sig. (2- & .341 & .296 & .071 & & .000 & .158 & .674 & .295 & .010 & .503 & .001 \\
\hline
\end{tabular}




\begin{tabular}{|c|c|c|c|c|c|c|c|c|c|c|c|c|}
\hline & $\begin{array}{l}\text { tailed) } \\
\mathrm{N}\end{array}$ & 30 & 30 & 30 & 30 & 30 & 30 & 30 & 30 & 30 & 30 & 30 \\
\hline \multirow[t]{3}{*}{ IDL5 } & $\begin{array}{l}\text { Pearson } \\
\text { Correlation }\end{array}$ & .032 & -.075 & .166 & $.658^{* *}$ & 1 & .182 & -.096 & .150 & .311 & .213 & $.379^{*}$ \\
\hline & $\begin{array}{l}\text { Sig. (2- } \\
\text { tailed) }\end{array}$ & .866 & .694 & .382 & .000 & & .336 & .615 & .429 & .094 & .258 & .039 \\
\hline & $\mathrm{N}$ & 30 & 30 & 30 & 30 & 30 & 30 & 30 & 30 & 30 & 30 & 30 \\
\hline \multirow[t]{3}{*}{ IDL6 } & $\begin{array}{l}\text { Pearson } \\
\text { Correlation }\end{array}$ & .351 & .226 & $.484^{* *}$ & .264 & .182 & 1 & -.044 & .000 & $.415^{*}$ & $.462^{*}$ & $.556^{* *}$ \\
\hline & $\begin{array}{l}\text { Sig. (2- } \\
\text { tailed) }\end{array}$ & .058 & .231 & .007 & .158 & .336 & & .816 & 1.000 & .022 & .010 & .001 \\
\hline & $\mathrm{N}$ & 30 & 30 & 30 & 30 & 30 & 30 & 30 & 30 & 30 & 30 & 30 \\
\hline \multirow[t]{3}{*}{ IDL7 } & $\begin{array}{l}\text { Pearson } \\
\text { Correlation }\end{array}$ & .266 & .337 & .044 & .080 & -.096 & -.044 & 1 & .289 & .200 & .227 & $.466^{* *}$ \\
\hline & $\begin{array}{l}\text { Sig. (2- } \\
\text { tailed) }\end{array}$ & .155 & .069 & .818 & .674 & .615 & .816 & & .121 & .289 & .227 & .009 \\
\hline & $\mathrm{N}$ & 30 & 30 & 30 & 30 & 30 & 30 & 30 & 30 & 30 & 30 & 30 \\
\hline \multirow[t]{3}{*}{ IDL8 } & $\begin{array}{l}\text { Pearson } \\
\text { Correlation }\end{array}$ & .223 & .125 & -.054 & .198 & .150 & .000 & .289 & 1 & .216 & .268 & $.445^{*}$ \\
\hline & $\begin{array}{l}\text { Sig. (2- } \\
\text { tailed) }\end{array}$ & .236 & .512 & .776 & .295 & .429 & 1.000 & .121 & & .251 & .152 & .014 \\
\hline & $\mathrm{N}$ & 30 & 30 & 30 & 30 & 30 & 30 & 30 & 30 & 30 & 30 & 30 \\
\hline \multirow[t]{3}{*}{ IDL9 } & $\begin{array}{l}\text { Pearson } \\
\text { Correlation }\end{array}$ & .069 & .350 & $.498^{* *}$ & $.461^{*}$ & .311 & $.415^{*}$ & .200 & .216 & 1 & $.475^{* *}$ & $.661^{* *}$ \\
\hline & $\begin{array}{l}\text { Sig. (2- } \\
\text { tailed) }\end{array}$ & .715 & .058 & .005 & .010 & .094 & .022 & .289 & .251 & & .008 & .000 \\
\hline & $\mathrm{N}$ & 30 & 30 & 30 & 30 & 30 & 30 & 30 & 30 & 30 & 30 & 30 \\
\hline
\end{tabular}




\begin{tabular}{|c|c|c|c|c|c|c|c|c|c|c|c|c|}
\hline \multirow[t]{2}{*}{$\begin{array}{l}\text { IDL1 } \\
0\end{array}$} & $\begin{array}{l}\text { Pearson } \\
\text { Correlation } \\
\text { Sig. (2- } \\
\text { tailed) }\end{array}$ & .465 & .192 & .105 & .503 & .258 & $.462^{*}$ & .227 & .152 & $.475^{* *}$ & 1 & $.626^{* *}$ \\
\hline & $\mathrm{N}$ & 30 & $\begin{array}{r}30 \\
615^{* *}\end{array}$ & $\begin{array}{r}30 \\
626^{* *}\end{array}$ & $\begin{array}{r}30 \\
572^{* *}\end{array}$ & $\frac{30}{270^{*}}$ & $\frac{30}{556^{* *}}$ & $\frac{30}{166^{* *}}$ & $\frac{30}{145^{*}}$ & $\begin{array}{r}30 \\
661^{* *}\end{array}$ & $\begin{array}{r}30 \\
626^{* *}\end{array}$ & 30 \\
\hline \multirow[t]{2}{*}{$\begin{array}{l}\text { IDLS } \\
\text { KOR }\end{array}$} & $\begin{array}{l}\text { Pearson } \\
\text { Correlation } \\
\text { Sig. (2- } \\
\text { tailed) }\end{array}$ & $.529^{* *}$ & $.615^{* *}$ & $\begin{array}{l}.626^{* *} \\
.000\end{array}$ & $\begin{array}{l}.573^{* *} \\
.001\end{array}$ & $.379^{*}$ & $.556^{*}$ & $.466^{*}$ & $.445^{\circ}$ & $\begin{array}{l}.661^{* \pi} \\
.000\end{array}$ & $\begin{array}{l}.626^{* *} \\
.000\end{array}$ & 1 \\
\hline & $\mathrm{N}$ & 30 & 30 & 30 & 30 & 30 & 30 & 30 & 30 & 30 & 30 & 30 \\
\hline
\end{tabular}


Tabel 19. Uji Reabilitas Relativisme

Reliability Statistics

\begin{tabular}{|r|c|c|}
\hline & $\begin{array}{c}\text { Cronbach's } \\
\text { Alpha Based } \\
\text { on } \\
\text { Standardized } \\
\text { Items }\end{array}$ & $\begin{array}{c}\text { N of } \\
\text { Items }\end{array}$ \\
\hline 0.839 & 0.841 & 10 \\
\hline
\end{tabular}

Item Statistics

\begin{tabular}{|l|r|r|r|}
\hline & \multicolumn{1}{|c|}{ Mean } & \multicolumn{1}{c|}{$\begin{array}{c}\text { Std. } \\
\text { Deviation }\end{array}$} & $\mathrm{N}$ \\
\hline REL1 & 2.4 & 0.85501 & 30 \\
REL2 & 3.4333 & 1.04 & 30 \\
REL3 & 3.5333 & 0.9732 & 30 \\
REL4 & 3.6333 & 0.96431 & 30 \\
REL5 & 3.2 & 1.0635 & 30 \\
REL6 & 3.2333 & 0.89763 & 30 \\
REL7 & 2.5333 & 0.9371 & 30 \\
REL8 & 3.0333 & 0.99943 & 30 \\
REL9 & 2.7667 & 0.89763 & 30 \\
REL10 & 2.7667 & 1.0063 & 30 \\
\hline
\end{tabular}

Inter-Item Correlation Matrix

\begin{tabular}{|l|r|r|r|r|r|r|r|r|r|r|}
\hline & REL1 & REL2 & REL3 & REL4 & REL5 & REL6 & REL7 & REL8 & REL9 & REL10 \\
\hline REL1 & 1 & 0.458 & 0.108 & 0.142 & 0.099 & 0.368 & 0.37 & 0.347 & 0.261 & 0.232 \\
REL2 & 0.458 & 1 & 0.343 & 0.336 & 0.387 & 0.738 & 0.462 & 0.417 & 0.334 & 0.298 \\
REL3 & 0.108 & 0.343 & 1 & 0.62 & 0.327 & 0.326 & 0.396 & 0.123 & - & 0.096 \\
& & & & & & & & & 0.011 & \\
REL4 & 0.142 & 0.336 & 0.62 & 1 & 0.04 & 0.461 & 0.262 & 0.085 & 0.137 & 0.193 \\
REL5 & 0.099 & 0.387 & 0.327 & 0.04 & 1 & 0.491 & 0.581 & 0.318 & 0.303 & 0.174 \\
REL6 & 0.368 & 0.738 & 0.326 & 0.461 & 0.491 & 1 & 0.544 & 0.529 & 0.541 & 0.559 \\
REL7 & 0.37 & 0.462 & 0.396 & 0.262 & 0.581 & 0.544 & 1 & 0.533 & 0.44 & 0.283 \\
REL8 & 0.347 & 0.417 & 0.123 & 0.085 & 0.318 & 0.529 & 0.533 & 1 & 0.432 & 0.351 \\
REL9 & 0.261 & 0.334 & - & 0.137 & 0.303 & 0.541 & 0.44 & 0.432 & 1 & 0.739 \\
REL10 & 0.232 & 0.298 & 0.096 & 0.193 & 0.174 & 0.559 & 0.283 & 0.351 & 0.739 & 1 \\
\hline
\end{tabular}


Item-Total Statistics

\begin{tabular}{|l|r|r|r|r|r|}
\hline & $\begin{array}{c}\text { Scale Mean } \\
\text { if Item } \\
\text { Deleted }\end{array}$ & $\begin{array}{c}\text { Scale } \\
\text { Variance if } \\
\text { Item } \\
\text { Deleted }\end{array}$ & $\begin{array}{c}\text { Corrected Item- } \\
\text { Total } \\
\text { Correlation }\end{array}$ & $\begin{array}{c}\text { Cronbach's } \\
\text { Squared } \\
\text { Multiple } \\
\text { Correlation }\end{array}$ & $\begin{array}{c}\text { Alpha if } \\
\text { Item } \\
\text { Deleted }\end{array}$ \\
\hline REL1 & 28.1333 & 33.43 & 0.4 & 0.3 & 0.836 \\
REL2 & 27.1 & 29.61 & 0.656 & 0.621 & 0.812 \\
REL3 & 27 & 32.759 & 0.396 & 0.577 & 0.837 \\
REL4 & 26.9 & 32.99 & 0.379 & 0.6 & 0.839 \\
REL5 & 27.3333 & 31.471 & 0.462 & 0.544 & 0.832 \\
REL6 & 27.3 & 29.321 & 0.822 & 0.79 & 0.798 \\
REL7 & 28 & 30.207 & 0.683 & 0.588 & 0.811 \\
REL8 & 27.5 & 31.155 & 0.535 & 0.425 & 0.824 \\
REL9 & 27.7667 & 31.771 & 0.548 & 0.658 & 0.823 \\
REL10 & 27.7667 & 31.564 & 0.49 & 0.64 & 0.829 \\
\hline
\end{tabular}

Scale Statistics

\begin{tabular}{|c|r|r|r|}
\hline Mean & Variance & $\begin{array}{c}\text { Std. } \\
\text { Deviation }\end{array}$ & $\begin{array}{c}\text { N of } \\
\text { Items }\end{array}$ \\
\hline 30.5333 & 38.12 & 6.1741 & 10 \\
\hline
\end{tabular}

Tabel 20. Uji Reabilitas Idealisme

Reliability Statistics

\begin{tabular}{|r|r|}
\hline Cronbach's Alpha & N of Items \\
\hline .733 & 10 \\
\hline
\end{tabular}

Item Statistics

\begin{tabular}{|l|r|r|rr|}
\hline & \multicolumn{1}{|c|}{ Mean } & \multicolumn{1}{c|}{$\begin{array}{c}\text { Std. } \\
\text { Deviation }\end{array}$} & $\mathrm{N}$ \\
\hline IDL1 & 3.9333 & .98027 & 30 \\
IDL2 & 3.1667 & 1.05318 & 30 \\
IDL3 & 3.9667 & .80872 & 30 \\
IDL4 & 4.2000 & .66436 & 30 \\
IDL5 & 4.2667 & .58329 & 30 \\
IDL6 & 4.1333 & .62881 & 30 \\
IDL7 & 2.9333 & .90719 & 30 \\
IDL8 & 4.0000 & .78784 & 30 \\
IDL9 & 4.1000 & .60743 & 30 \\
IDL10 & 3.9333 & .98027 & 30 \\
\hline
\end{tabular}


Item-Total Statistics

\begin{tabular}{|l|c|c|c|r|}
\hline & $\begin{array}{c}\text { Scale } \\
\text { Mean if } \\
\text { Item } \\
\text { Deleted }\end{array}$ & $\begin{array}{c}\text { Scale } \\
\text { Variance if } \\
\text { Item } \\
\text { Deleted }\end{array}$ & $\begin{array}{c}\text { Corrected } \\
\text { Item-Total } \\
\text { Correlation }\end{array}$ & $\begin{array}{c}\text { Cronbach's } \\
\text { Alpha if } \\
\text { Item } \\
\text { Deleted }\end{array}$ \\
\hline IDL1 & 34.7000 & 16.148 & .319 & .727 \\
IDL2 & 35.4667 & 14.947 & .438 & .706 \\
IDL3 & 34.6667 & 15.816 & .490 & .697 \\
IDL4 & 34.4333 & 16.737 & .449 & .706 \\
IDL5 & 34.3667 & 18.033 & .252 & .730 \\
IDL6 & 34.5000 & 16.810 & .468 & .705 \\
IDL7 & 35.7000 & 16.631 & .293 & .729 \\
IDL8 & 34.6333 & 17.137 & .285 & .728 \\
IDL9 & 34.5333 & 16.326 & .596 & .690 \\
IDL10 & 34.7000 & 15.045 & .475 & .698 \\
\hline
\end{tabular}

Scale Statistics

\begin{tabular}{|c|r|r|r|}
\hline Mean & Variance & $\begin{array}{c}\text { Std. } \\
\text { Deviation }\end{array}$ & N of Items \\
\hline 38.6333 & 19.620 & 4.42940 & 10 \\
\hline
\end{tabular}

Tabel 21. Data Pilot Test Kasus Tidak Ada Asimetri Informasi

\begin{tabular}{|c|c|c|c|c|c|c|c|}
\hline & & $\overline{\text { KASUS }}$ & $\overline{\mathrm{AAK}} \mathrm{ADA} A$ & METRI II & RMASI & & \\
\hline Jeni & Kelamin & & & Manipul & $\begin{array}{l}\text { n Check (8 } \\
\text { l) }\end{array}$ & & \\
\hline Pria & Wanita & Umur & IPK & $\begin{array}{c}\text { Jawaban } \\
\text { yang } \\
\text { Benar }\end{array}$ & $\begin{array}{c}\text { Jawaban } \\
\text { yang Salah }\end{array}$ & kebenaran & Ket \\
\hline & $\mathrm{V}$ & 21 & $3,26-3,50$ & 8 & 0 & 100 & Lolos \\
\hline $\mathrm{V}$ & & 21 & $3,26-3,50$ & 8 & 0 & 88 & Lolos \\
\hline $\mathrm{v}$ & & 21 & $3,26-3,50$ & 4 & 4 & 50 & Tidak Lolos \\
\hline & $\mathrm{v}$ & 22 & $>3,51$ & 8 & 0 & 100 & Lolos \\
\hline $\mathrm{v}$ & & 21 & $3,00-3,25$ & 8 & 0 & 100 & Lolos \\
\hline $\mathrm{v}$ & & 22 & $3,26-3,50$ & 8 & 0 & 100 & Lolos \\
\hline & $\mathrm{v}$ & 22 & $3,00-3,25$ & 8 & 0 & 100 & Lolos \\
\hline $\mathrm{V}$ & & 22 & $3,26-3,50$ & 8 & 0 & 100 & Lolos \\
\hline & $\mathrm{v}$ & 21 & $>3,51$ & 8 & 0 & 100 & Lolos \\
\hline & $\mathrm{v}$ & 21 & $3,26-3,52$ & 8 & 0 & 100 & Lolos \\
\hline
\end{tabular}


Tabel 22. Data Pilot Test Kasus Asimetri Informasi Rendah

\begin{tabular}{|c|c|c|c|c|c|c|c|}
\hline \multicolumn{7}{|c|}{ KASUS ASIMETRI INFORMASI RENDAH } & \multirow[b]{3}{*}{ Ket } \\
\hline \multicolumn{2}{|c|}{ Jenis Kelamin } & \multirow[b]{2}{*}{ Umur } & \multirow[b]{2}{*}{ IPK } & \multicolumn{2}{|c|}{$\begin{array}{l}\text { Manipulation Check (8 } \\
\text { soal) }\end{array}$} & \multirow{2}{*}{$\begin{array}{c}\% \\
\text { kebenaran }\end{array}$} & \\
\hline \multirow[t]{2}{*}{ Pria } & $\begin{array}{l}\text { Wanit } \\
\text { a }\end{array}$ & & & $\begin{array}{c}\text { Jawaban } \\
\text { yang } \\
\text { Benar }\end{array}$ & $\begin{array}{c}\text { Jawaban } \\
\text { yang Salah } \\
\end{array}$ & & \\
\hline & $\mathrm{v}$ & 21 & $3,26-3,50$ & 8 & 0 & 100 & Lolos \\
\hline $\mathrm{v}$ & & 22 & $3,26-3,51$ & 8 & 0 & 100 & Lolos \\
\hline $\mathrm{v}$ & & 22 & $3,26-3,52$ & 8 & 0 & 100 & Lolos \\
\hline $\mathrm{v}$ & & 22 & $>3,51$ & 8 & 0 & 100 & Lolos \\
\hline $\mathrm{v}$ & & 22 & $3,00-3,25$ & 8 & 0 & 100 & Lolos \\
\hline \multirow[t]{4}{*}{$\mathrm{v}$} & & 21 & $3,26-3,50$ & 8 & 0 & 100 & Lolos \\
\hline & $\mathrm{v}$ & 22 & $3,00-3,25$ & 8 & 0 & 100 & Lolos \\
\hline & $\mathrm{v}$ & 22 & $3,26-3,50$ & 8 & 0 & 100 & Lolos \\
\hline & $\mathrm{v}$ & 21 & $3,26-3,51$ & 3 & 5 & 38 & Tidak Lolos \\
\hline $\mathrm{v}$ & & 21 & $3,26-3,52$ & 4 & 4 & 50 & Tidak Lolos \\
\hline
\end{tabular}

Tabel 23. Data Pilot Test Kasus Asimetri Informasi Tinggi

\begin{tabular}{|c|c|c|c|c|c|c|c|}
\hline \multicolumn{7}{|c|}{ KASUS ASIMETRI INFORMASI TINGGI } & \multirow[b]{3}{*}{ Ket } \\
\hline \multicolumn{2}{|c|}{ Jenis Kelamin } & \multirow[b]{2}{*}{ Umur } & \multirow[b]{2}{*}{ IPK } & \multicolumn{2}{|c|}{$\begin{array}{c}\text { Manipulation Check } \\
(8 \text { soal }) \\
\end{array}$} & \multirow[b]{2}{*}{$\begin{array}{c}\% \\
\text { Kebenaran }\end{array}$} & \\
\hline \multirow[t]{2}{*}{ Pria } & Wanita & & & $\begin{array}{c}\text { Jawaban } \\
\text { yang } \\
\text { Benar }\end{array}$ & $\begin{array}{c}\text { Jawaban } \\
\text { yang } \\
\text { Salah }\end{array}$ & & \\
\hline & $\mathrm{V}$ & 21 & $3,25-3,50$ & 8 & 0 & 100 & Lolos \\
\hline $\mathrm{V}$ & & 22 & $3,00-3,25$ & 8 & 0 & 100 & Lolos \\
\hline \multirow[t]{2}{*}{$\mathrm{V}$} & & 22 & $3,25-3,50$ & 8 & 0 & 100 & Lolos \\
\hline & $\mathrm{V}$ & 22 & $>3,51$ & 8 & 0 & 100 & Lolos \\
\hline $\mathrm{V}$ & & 21 & $3,00-3,25$ & 8 & 0 & 100 & Lolos \\
\hline \multirow[t]{2}{*}{$\mathrm{V}$} & & 21 & $>3,51$ & 8 & 0 & 100 & Lolos \\
\hline & $\mathrm{V}$ & 22 & $>3,51$ & 8 & 0 & 100 & Lolos \\
\hline $\mathrm{V}$ & $\mathrm{V}$ & 21 & $3,25-3,50$ & 3 & 5 & 38 & Tidak Lolos \\
\hline $\mathrm{V}$ & & 21 & $3,25-3,50$ & 8 & 0 & 100 & Lolos \\
\hline $\mathrm{V}$ & & 21 & $3,25-3,50$ & 8 & 0 & 100 & Lolos \\
\hline
\end{tabular}




\section{LAMPIRAN 4}


Tabel 24. Uji Kolmogorov-Smirnov Senjangan Anggaran Berdasarkan Asimetri Informasi

Descriptive Statistics

\begin{tabular}{|c|c|c|c|c|c|}
\hline & $\mathrm{N}$ & Mean & $\begin{array}{c}\text { Std. } \\
\text { Deviation }\end{array}$ & Minimum & Maximum \\
\hline NONE & 46 & .2464 & .23606 & .00 & .80 \\
\hline LOW & 47 & .4107 & .24634 & .00 & 1.00 \\
\hline HIGH & 48 & .5688 & .27855 & .00 & 1.00 \\
\hline
\end{tabular}

One-Sample Kolmogorov-Smirnov Test

\begin{tabular}{|ll|r|r|r|}
\hline & & \multicolumn{1}{|c|}{ NONE } & \multicolumn{1}{c|}{ LOW } & \multicolumn{1}{c|}{ HIGH } \\
\hline $\mathrm{N}$ & & 46 & 47 & 48 \\
Normal & Mean & .2464 & .4107 & .5688 \\
Parameters $^{\mathrm{a}, \mathrm{b}}$ & Std. & .23606 & .24634 & .27855 \\
& Deviation & & & \\
Most Extreme & Absolute & .148 & .113 & .095 \\
Differences & Positive & .146 & .113 & .095 \\
& Negative & -.148 & -.063 & -.090 \\
Kolmogorov-Smirnov Z & 1.006 & .775 & .660 \\
Asymp. Sig. (2-tailed) & .264 & .585 & .777 \\
\hline
\end{tabular}

Tabel 25. Uji Kolmogorov-Smirnov Variabel Orientasi Etika

Descriptive Statistics

\begin{tabular}{|l|l|l|r|r|r|}
\hline & $\mathrm{N}$ & Mean & $\begin{array}{c}\text { Std. } \\
\text { Deviation }\end{array}$ & \multicolumn{1}{c|}{ Minimum } & Maximum \\
\hline RELATIVISME & 141 & 33.1560 & 4.55488 & 23.00 & 44.00 \\
IDEALISME & 141 & 38.7447 & 4.30515 & 26.00 & 49.00 \\
\hline
\end{tabular}

One-Sample Kolmogorov-Smirnov Test

\begin{tabular}{|c|c|c|c|}
\hline & & RELATIVISME & IDEALISME \\
\hline $\mathrm{N}$ & & 141 & 141 \\
\hline \multirow{2}{*}{ Normal Parameters $^{\mathrm{a}, \mathrm{b}}$} & Mean & 33.156 & 38.7447 \\
\hline & $\begin{array}{l}\text { Std. } \\
\text { Deviation }\end{array}$ & 4.55488 & 4.30515 \\
\hline & Absolute & 0.077 & 0.073 \\
\hline \multirow{2}{*}{ Differences } & Positive & 0.051 & 0.073 \\
\hline & Negative & -0.077 & -0.07 \\
\hline Kolmogorov-Smirnov Z & & 0.915 & 0.87 \\
\hline Asymp. Sig. (2-tailed) & & 0.373 & 0.436 \\
\hline
\end{tabular}

a. Test distribution is Normal.

b. Calculated from data. 
Tabel 26. Uji Homogenitas Varians Variabel Asimetri Informasi Levene's Test of Equality of Error Variances ${ }^{a}$

Dependent Variable:SLACK

\begin{tabular}{|r|r|r|rr|}
\hline F & df1 & df2 & Sig. \\
\hline 1.167 & & 2 & 138 & \\
\hline
\end{tabular}

Tests the null hypothesis that the error variance of the dependent variable is equal across groups.

a. Design: Intercept + INF

Tabel 27. Uji Homogenitas Varians Variabel Asimetri Informasi dan Relativisme

Levene's Test of Equality of Error Variances ${ }^{a}$

Dependent Variable:SLACK

\begin{tabular}{|c|c|c|c|}
\hline $\mathrm{F}$ & dfl & $\mathrm{df} 2$ & Sig. \\
\hline .665 & 5 & 135 & 650 \\
\hline
\end{tabular}

Tests the null hypothesis that the error variance of the dependent variable is equal across groups.

a. Design: Intercept + INF + INF * REL

Tabel 28. Uji Homogenitas Varians Variabel Asimetri Informasi dan Idealisme

\section{Levene's Test of Equality of Error Variances ${ }^{a}$}

Dependent Variable:SLACK

\begin{tabular}{|r|r|r|r|}
\hline F & df1 & \multicolumn{1}{|c|}{ df2 } & \multicolumn{1}{|c|}{ Sig. } \\
\hline .577 & 5 & 135 & .717 \\
\hline
\end{tabular}

Tests the null hypothesis that the error variance of the dependent variable is equal across groups.

a. Design: Intercept $+\mathrm{INF}+\mathrm{INF} * \mathrm{IDL}$ 
Tabel 29. Uji Homogenitas Varians Orientasi Etika

\section{Levene's Test of Equality of Error Variances ${ }^{a}$}

Dependent Variable:SLACK

\begin{tabular}{|r|r|r|r|}
\hline F & \multicolumn{1}{|c|}{ df1 } & \multicolumn{1}{c|}{ df2 } & \multicolumn{1}{|c|}{ Sig. } \\
\hline .647 & 11 & 129 & .785 \\
\hline
\end{tabular}

Tests the null hypothesis that the error variance of the dependent variable is equal across groups.

a. Design: Intercept + INF + INF * KLASIFIKASI 


\section{LAMPIRAN}

5 
Tabel 30. Statistik Deskriptif Senjangan Anggaran Berdasarkan Asimetri Informasi dan Orientasi Etika

\section{Descriptive Statistics}

Dependent Variable:SLACK

\begin{tabular}{|c|c|c|c|c|c|}
\hline INF & REL & IDL & Mean & $\begin{array}{c}\text { Std. } \\
\text { Deviation }\end{array}$ & $\mathrm{N}$ \\
\hline \multirow[t]{9}{*}{ None } & \multirow[t]{3}{*}{ Low } & Low & .2586 & .20873 & 9 \\
\hline & & High & .2094 & .23646 & 13 \\
\hline & & Total & .2295 & .22172 & 22 \\
\hline & \multirow[t]{3}{*}{ High } & Low & .2754 & .28643 & 12 \\
\hline & & High & .2484 & .22491 & 12 \\
\hline & & Total & .2619 & .25223 & 24 \\
\hline & \multirow[t]{3}{*}{ Total } & Low & .2682 & .25024 & 21 \\
\hline & & High & .2281 & .22702 & 25 \\
\hline & & Total & .2464 & .23606 & 46 \\
\hline \multirow[t]{9}{*}{ Low } & \multirow[t]{3}{*}{ Low } & Low & .4061 & .25179 & 9 \\
\hline & & High & .3127 & .19761 & 13 \\
\hline & & Total & .3509 & .22063 & 22 \\
\hline & \multirow[t]{3}{*}{ High } & Low & .4910 & .24676 & 12 \\
\hline & & High & .4378 & .27897 & 13 \\
\hline & & Total & .4633 & .25991 & 25 \\
\hline & \multirow[t]{3}{*}{ Total } & Low & .4546 & .24638 & 21 \\
\hline & & High & .3752 & .24530 & 26 \\
\hline & & Total & .4107 & .24634 & 47 \\
\hline \multirow[t]{9}{*}{ High } & \multirow[t]{3}{*}{ Low } & Low & .5487 & .30430 & 15 \\
\hline & & High & .4985 & .27830 & 11 \\
\hline & & Total & .5274 & .28892 & 26 \\
\hline & \multirow[t]{3}{*}{ High } & Low & .7427 & .18813 & 8 \\
\hline & & High & .5462 & .27988 & 14 \\
\hline & & Total & .6176 & .26392 & 22 \\
\hline & \multirow[t]{3}{*}{ Total } & Low & .6162 & .28128 & 23 \\
\hline & & High & .5252 & .27438 & 25 \\
\hline & & Total & .5688 & .27855 & 48 \\
\hline \multirow[t]{5}{*}{ Total } & \multirow[t]{3}{*}{ Low } & Low & .4307 & .28684 & 33 \\
\hline & & High & .3316 & .25923 & 37 \\
\hline & & Total & .3783 & .27513 & 70 \\
\hline & \multirow[t]{2}{*}{ High } & Low & .4731 & .30450 & 32 \\
\hline & & High & .4184 & .28510 & 39 \\
\hline
\end{tabular}




\begin{tabular}{|rl|r|r|r|} 
& Total & .4431 & .29315 & 71 \\
\hline \multirow{4}{*}{ Total } & Low & .4515 & .29412 & 65 \\
& High & .3762 & .27450 & 76 \\
& Total & .4109 & .28519 & 141 \\
\hline
\end{tabular}

Tabel 31. Uji Hipotesis Asimetri Informasi terhadap Senjangan Anggaran Between-Subjects Factors

\begin{tabular}{|ll|r|}
\hline & & N \\
\hline INF & 0 & 46 \\
& 1 & 47 \\
& 2 & 48 \\
\hline
\end{tabular}

\section{Descriptive Statistics}

Dependent Variable:SLACK

\begin{tabular}{|l|r|r|r|}
\hline INF & Mean & $\begin{array}{c}\text { Std. } \\
\text { Deviation }\end{array}$ & \multicolumn{1}{c|}{ N } \\
\hline 0 & .2464 & .23606 & 46 \\
1 & .4107 & .24634 & 47 \\
2 & .5688 & .27855 & 48 \\
Total & .4109 & .28519 & 141 \\
\hline
\end{tabular}

\section{Levene's Test of Equality of Error Variances $^{\mathrm{a}}$}

Dependent Variable:SLACK

\begin{tabular}{|c|r|r|c|}
\hline F & df1 & df2 & Sig. \\
\hline 1.167 & 2 & 138 & .314 \\
\hline
\end{tabular}


Tests of Between-Subjects Effects

Dependent Variable:SLACK

\begin{tabular}{|c|c|c|c|c|c|}
\hline Source & $\begin{array}{c}\text { Type } \\
\text { III Sum } \\
\text { of } \\
\text { Squares }\end{array}$ & $\mathrm{df}$ & $\begin{array}{l}\text { Mean } \\
\text { Square }\end{array}$ & $\mathrm{F}$ & Sig. \\
\hline $\begin{array}{l}\text { Corrected } \\
\text { Model }\end{array}$ & $2.441^{\mathrm{a}}$ & 2 & 1.220 & 18.826 & .000 \\
\hline Intercept & 23.536 & 1 & 23.536 & 363.077 & .000 \\
\hline INF & 2.441 & 2 & 1.220 & 18.826 & .000 \\
\hline Error & 8.946 & 138 & .065 & & \\
\hline Total & 35.194 & 141 & & & \\
\hline $\begin{array}{l}\text { Corrected } \\
\text { Total }\end{array}$ & 11.387 & 140 & & & \\
\hline
\end{tabular}

\section{Grand Mean}

Dependent Variable:SLACK

\begin{tabular}{|c|c|c|r|}
\hline \multirow{2}{*}{ Mean } & \multirow{3}{*}{ Std. } & \multicolumn{2}{|c|}{$\begin{array}{c}\text { 95\% Confidence } \\
\text { Interval }\end{array}$} \\
\cline { 3 - 4 } & Error & $\begin{array}{c}\text { Lower } \\
\text { Bound }\end{array}$ & $\begin{array}{c}\text { Upper } \\
\text { Bound }\end{array}$ \\
\hline .409 & .021 & .366 & .451 \\
\hline
\end{tabular}

\section{INF}

Dependent Variable:SLACK

\begin{tabular}{|c|c|c|c|c|}
\hline \multirow[b]{2}{*}{ INF } & \multirow[b]{2}{*}{ Mean } & \multirow[b]{2}{*}{ Std. Error } & \multicolumn{2}{|c|}{$\begin{array}{c}95 \% \text { Confidence } \\
\text { Interval }\end{array}$} \\
\hline & & & $\begin{array}{l}\text { Lower } \\
\text { Bound }\end{array}$ & $\begin{array}{l}\text { Upper } \\
\text { Bound }\end{array}$ \\
\hline 0 & .246 & .038 & .172 & .321 \\
\hline 1 & .411 & .037 & .337 & .484 \\
\hline 2 & .569 & .037 & .496 & .641 \\
\hline
\end{tabular}


SLACK

Multiple Comparisons

Scheffe

\begin{tabular}{|c|c|c|c|c|c|c|}
\hline \multirow[b]{2}{*}{ (I) INF } & \multirow[b]{2}{*}{$(\mathrm{J}) \mathrm{INF}$} & \multirow{2}{*}{$\begin{array}{c}\text { Mean } \\
\text { Difference } \\
(\mathrm{I}-\mathrm{J})\end{array}$} & \multirow[b]{2}{*}{$\begin{array}{l}\text { Std. } \\
\text { Error }\end{array}$} & \multirow[b]{2}{*}{ Sig. } & \multicolumn{2}{|c|}{$\begin{array}{c}95 \% \\
\text { Confidence } \\
\text { Interval }\end{array}$} \\
\hline & & & & & $\begin{array}{l}\text { Lower } \\
\text { Bound }\end{array}$ & $\begin{array}{l}\text { Upper } \\
\text { Bound }\end{array}$ \\
\hline \multirow[t]{2}{*}{0} & 1 & $-.1643^{*}$ & .05281 & .009 & -.2949 & -.0336 \\
\hline & 2 & $-.3224^{*}$ & .05253 & .000 & -.4523 & -.1924 \\
\hline \multirow[t]{2}{*}{1} & 0 & $.1643^{*}$ & .05281 & .009 & .0336 & .2949 \\
\hline & 2 & $-.1581^{*}$ & .05225 & .012 & -.2874 & -.0288 \\
\hline \multirow[t]{2}{*}{2} & 0 & $.3224^{*}$ & .05253 & .000 & .1924 & .4523 \\
\hline & 1 & $.1581^{*}$ & .05225 & .012 & .0288 & .2874 \\
\hline
\end{tabular}

\section{SLACK}

Scheffe ${ }^{a, b,, c}$

\begin{tabular}{|l|r|r|c|c|}
\hline & & \multicolumn{3}{|c|}{ Subset } \\
\cline { 3 - 5 } INF & $\mathrm{N}$ & 1 & 2 & 3 \\
\hline 0 & 46 & .2464 & & \\
1 & 47 & & .4107 & \\
2 & 48 & & & .5688 \\
Sig. & & 1.000 & 1.000 & 1.000 \\
\hline
\end{tabular}


Gambar 1. Senjangan Anggaran Berdasarkan Asimetri Informasi

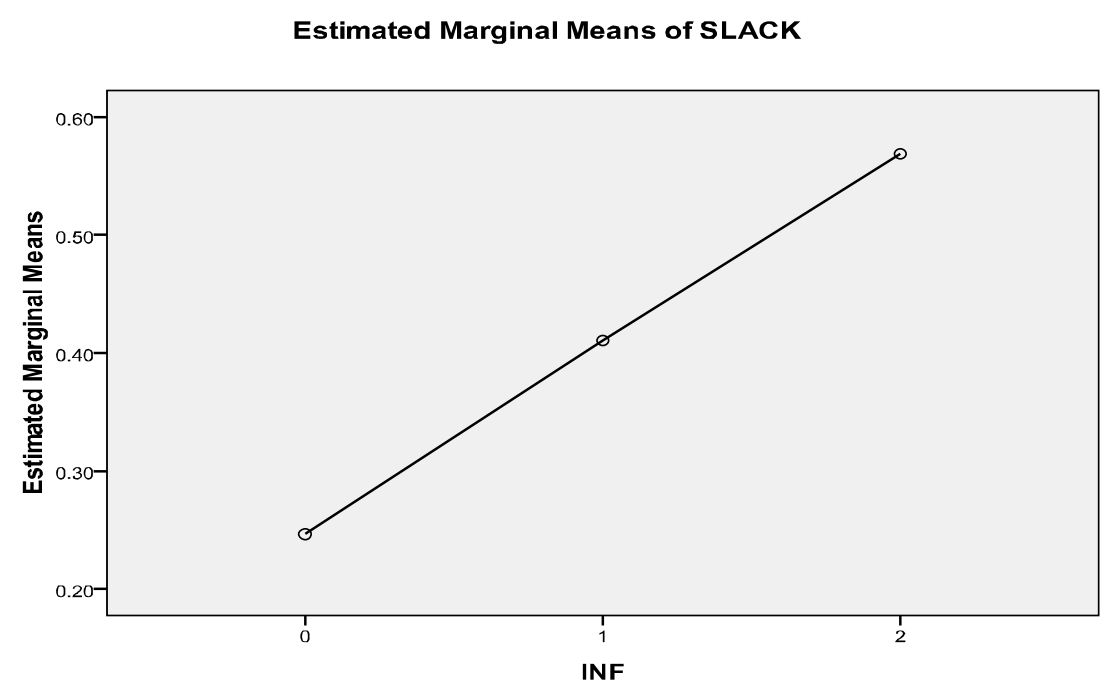

Tabel 32. Uji Hipotesis Asimetri Informasi terhadap Senjangan Anggaran dengan Relativisme sebagai Moderating

Between-Subjects Factors

\begin{tabular}{|c|c|c|}
\hline & & $\mathrm{N}$ \\
\hline \multirow[t]{3}{*}{ INF } & 0 & 46 \\
\hline & 1 & 47 \\
\hline & 2 & 48 \\
\hline \multirow[t]{2}{*}{ REL } & 0 & 70 \\
\hline & 1 & 71 \\
\hline
\end{tabular}


Descriptive Statistics

Dependent Variable:SLACK

\begin{tabular}{|ll|r|r|r|}
\hline INF & REL & Mean & Std. Deviation & N \\
\hline 0 & 0 & .2295 & .22172 & 22 \\
& 1 & .2619 & .25223 & 24 \\
& Total & .2464 & .23606 & 46 \\
\hline 1 & 0 & .3509 & .22063 & 22 \\
& 1 & .4633 & .25991 & 25 \\
& Total & .4107 & .24634 & 47 \\
\hline 2 & 0 & .5274 & .28892 & 26 \\
& 1 & .6176 & .26392 & 22 \\
& Total & .5688 & .27855 & 48 \\
\hline Total & 0 & .3783 & .27513 & 70 \\
& 1 & .4431 & .29315 & 71 \\
& Total & .4109 & .28519 & 141 \\
\hline
\end{tabular}

Tests of Between-Subjects Effects

Dependent Variable:SLACK

\begin{tabular}{|l|r|r|r|r|r|}
\hline Source & $\begin{array}{c}\text { Type } \\
\text { III Sum } \\
\text { of } \\
\text { Square } \\
\text { s }\end{array}$ & df & \multicolumn{1}{c|}{$\begin{array}{c}\text { Mean } \\
\text { Square }\end{array}$} & \multicolumn{1}{c|}{ F } & Sig. \\
\hline $\begin{array}{l}\text { Corrected } \\
\text { Model }\end{array}$ & $2.698^{\mathrm{a}}$ & 5 & .540 & 8.383 & .000 \\
Intercept & 23.415 & 1 & 23.415 & 363.81 & .000 \\
INF & 2.499 & 2 & 1.249 & 19.412 & .000 \\
REL & .215 & 1 & .215 & 3.347 & .070 \\
INF * REL & .040 & 2 & .020 & .307 & .736 \\
Error & 8.689 & 135 & .064 & & \\
Total & 35.194 & 141 & & & \\
Corrected & 11.387 & 140 & & & \\
Total & & & & & \\
\hline
\end{tabular}




\section{Grand Mean}

Dependent Variable:SLACK

\begin{tabular}{|c|c|c|c|}
\hline \multirow{2}{*}{ Mean } & & \multicolumn{2}{|c|}{$\begin{array}{c}\text { 95\% Confidence } \\
\text { Interval }\end{array}$} \\
\cline { 3 - 4 } & \multirow{2}{*}{$\begin{array}{c}\text { Std. } \\
\text { Error }\end{array}$} & $\begin{array}{c}\text { Lower } \\
\text { Boun } \\
\mathrm{d}\end{array}$ & $\begin{array}{c}\text { Upper } \\
\text { Bound }\end{array}$ \\
\hline .408 & .021 & .366 & .451 \\
\hline
\end{tabular}

\section{INF}

Dependent Variable:SLACK

\begin{tabular}{|c|c|c|c|c|}
\hline \multirow[b]{2}{*}{ INF } & \multirow[b]{2}{*}{ Mean } & \multirow[b]{2}{*}{$\begin{array}{l}\text { Std. } \\
\text { Error }\end{array}$} & \multicolumn{2}{|c|}{$\begin{array}{l}95 \% \text { Confidence } \\
\text { Interval } \\
\end{array}$} \\
\hline & & & $\begin{array}{l}\text { Lower } \\
\text { Bound } \\
\end{array}$ & $\begin{array}{l}\text { Upper } \\
\text { Bound } \\
\end{array}$ \\
\hline 0 & .246 & .037 & .172 & .320 \\
\hline 1 & .407 & .037 & .334 & .480 \\
\hline 2 & .573 & .037 & .500 & .645 \\
\hline
\end{tabular}

\section{REL}

Dependent Variable:SLACK

\begin{tabular}{|c|c|c|c|c|}
\hline \multirow[b]{2}{*}{ REL } & \multirow[b]{2}{*}{ Mean } & \multirow[b]{2}{*}{$\begin{array}{l}\text { Std. } \\
\text { Error }\end{array}$} & \multicolumn{2}{|c|}{$\begin{array}{l}95 \% \text { Confidence } \\
\text { Interval }\end{array}$} \\
\hline & & & $\begin{array}{l}\text { Lower } \\
\text { Bound }\end{array}$ & $\begin{array}{l}\text { Upper } \\
\text { Bound }\end{array}$ \\
\hline 0 & .369 & .030 & .309 & .429 \\
\hline 1 & .448 & .030 & .388 & .507 \\
\hline
\end{tabular}




\section{INF * REL}

Dependent Variable:SLACK

\begin{tabular}{|c|c|c|c|c|c|}
\hline & & & & $\begin{array}{r}95 \% \mathrm{Co} \\
\text { Inte }\end{array}$ & $\begin{array}{l}\text { fidence } \\
\text { val }\end{array}$ \\
\hline INF & REL & Mean & Std. Error & $\begin{array}{l}\text { Lower } \\
\text { Bound }\end{array}$ & $\begin{array}{c}\text { Upper } \\
\text { Boun } \\
d\end{array}$ \\
\hline 0 & 0 & .230 & .054 & .123 & .336 \\
\hline & 1 & .262 & .052 & .159 & .364 \\
\hline 1 & 0 & .351 & .054 & .244 & .458 \\
\hline & 1 & .463 & .051 & .363 & .564 \\
\hline 2 & 0 & .527 & .050 & .429 & .626 \\
\hline & 1 & .618 & .054 & .511 & .725 \\
\hline
\end{tabular}

Multiple Comparisons

Dependent Variable:SLACK

\begin{tabular}{|c|c|c|c|c|c|c|c|}
\hline & \multirow[b]{2}{*}{ (I) INF } & \multirow[b]{2}{*}{$\begin{array}{l}(\mathrm{J}) \\
\text { INF }\end{array}$} & \multirow{2}{*}{$\begin{array}{c}\text { Mean } \\
\text { Differenc } \\
\text { e (I-J) }\end{array}$} & \multirow[b]{2}{*}{$\begin{array}{l}\text { Std. } \\
\text { Error }\end{array}$} & \multirow[b]{2}{*}{ Sig. } & \multicolumn{2}{|c|}{$\begin{array}{l}95 \% \text { Confidence } \\
\text { Interval }\end{array}$} \\
\hline & & & & & & $\begin{array}{l}\text { Lower } \\
\text { Bound }\end{array}$ & $\begin{array}{l}\text { Upper } \\
\text { Bound }\end{array}$ \\
\hline \multirow[t]{6}{*}{ Scheffe } & \multirow[t]{2}{*}{0} & 1 & $-.1643^{*}$ & .05262 & .009 & -.2945 & -.0340 \\
\hline & & 2 & $-.3224^{*}$ & .05235 & .000 & -.4519 & -.1928 \\
\hline & \multirow[t]{2}{*}{1} & 0 & $.1643^{*}$ & .05262 & .009 & .0340 & .2945 \\
\hline & & 2 & $-.1581^{*}$ & .05206 & .012 & -.2869 & -.0292 \\
\hline & \multirow[t]{2}{*}{2} & 0 & $.3224^{*}$ & .05235 & .000 & .1928 & .4519 \\
\hline & & 1 & $.1581^{*}$ & .05206 & .012 & .0292 & .2869 \\
\hline
\end{tabular}

SLACK

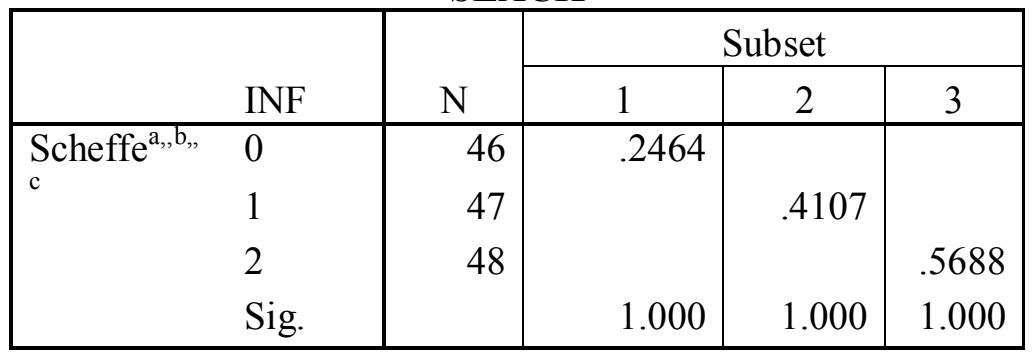


Gambar 2. Grafik Senjangan Anggaran Berdasarkan Relativisme

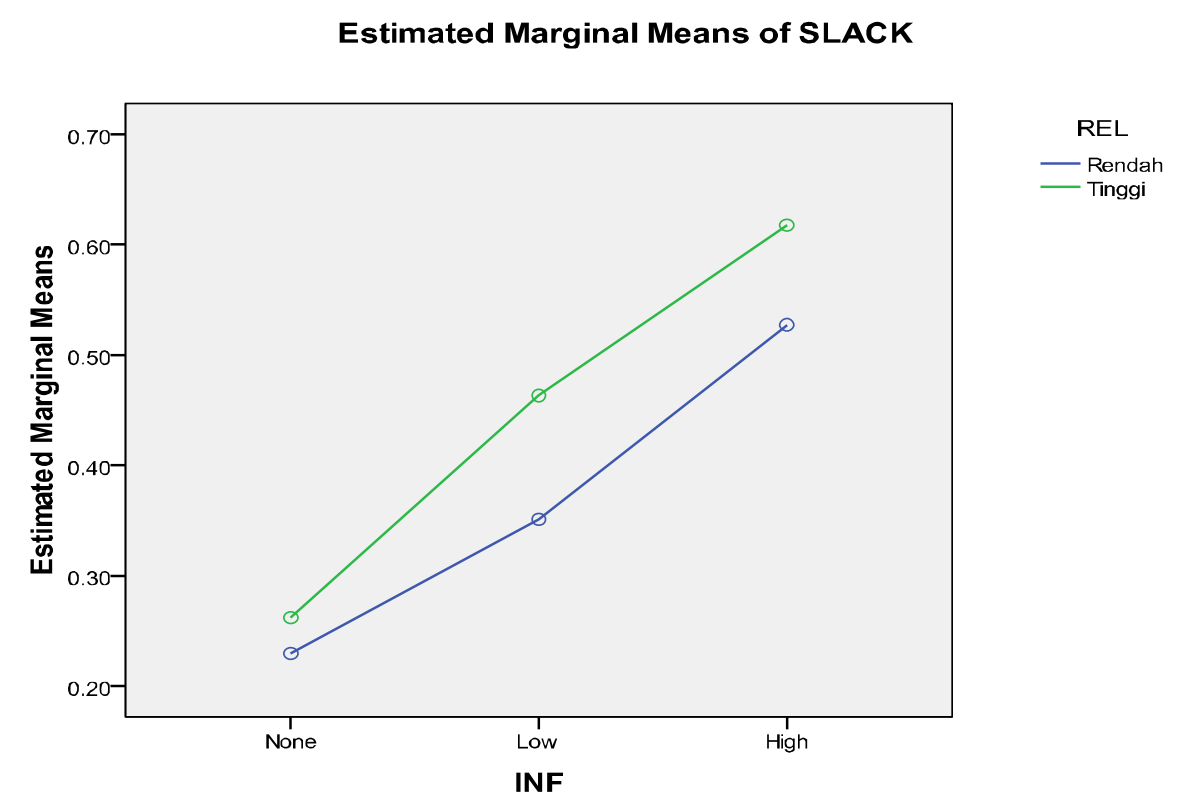

Tabel 33. Uji Hipotesis Asimetri Informasi terhadap Senjangan Anggaran dengan Idealisme sebagai Moderating

Between-Subjects Factors

\begin{tabular}{|ll|r|}
\hline & & $\mathrm{N}$ \\
\hline INF & 0 & 46 \\
& 1 & 47 \\
& 2 & 48 \\
& 0 & 65 \\
IDL & 1 & 76 \\
& & \\
\hline
\end{tabular}




\section{Descriptive Statistics}

Dependent Variable:SLACK

\begin{tabular}{|ll|r|r|r|}
\hline INF & IDL & Mean & Std. Deviation & N \\
\hline 0 & 0 & .2682 & .25024 & 21 \\
& 1 & .2281 & .22702 & 25 \\
& Total & .2464 & .23606 & 46 \\
\hline 1 & 0 & .4546 & .24638 & 21 \\
& 1 & .3752 & .24530 & 26 \\
& Total & .4107 & .24634 & 47 \\
\hline 2 & 0 & .6162 & .28128 & 23 \\
& 1 & .5252 & .27438 & 25 \\
& Total & .5688 & .27855 & 48 \\
\hline Total & 0 & .4515 & .29412 & 65 \\
& 1 & .3762 & .27450 & 76 \\
& Total & .4109 & .28519 & 141 \\
\hline
\end{tabular}

Tests of Between-Subjects Effects

Dependent Variable:SLACK

\begin{tabular}{|l|r|r|r|r|r|}
\hline Source & $\begin{array}{c}\text { Type } \\
\text { III Sum } \\
\text { of } \\
\text { Squares }\end{array}$ & \multicolumn{1}{|c|}{ df } & \multicolumn{1}{c|}{$\begin{array}{c}\text { Mean } \\
\text { Square }\end{array}$} & \multicolumn{1}{c|}{ F } & \multicolumn{1}{c|}{ Sig. } \\
\hline Corrected & $2.631^{\mathrm{a}}$ & 5 & .526 & 8.115 & .000 \\
Model & & & & & \\
Intercept & 23.674 & 1 & 23.674 & 365.039 & .000 \\
INF & 2.432 & 2 & 1.216 & 18.748 & .000 \\
IDL & .172 & 1 & .172 & 2.654 & .106 \\
INF $*$ & .016 & 2 & .008 & .127 & .881 \\
IDL & & & & & \\
Error & 8.755 & 135 & .065 & & \\
Total & 35.194 & 141 & & & \\
& & & & & \\
Corrected & 11.387 & 140 & & & \\
Total & & & & & \\
\hline
\end{tabular}




\section{Grand Mean}

Dependent Variable:SLACK

\begin{tabular}{|c|c|c|c|}
\hline \multirow[b]{2}{*}{ Mean } & \multirow[b]{2}{*}{$\begin{array}{l}\text { Std. } \\
\text { Error }\end{array}$} & \multicolumn{2}{|c|}{$\begin{array}{l}\text { 95\% Confidence } \\
\text { Interval }\end{array}$} \\
\hline & & $\begin{array}{l}\text { Lower } \\
\text { Bound }\end{array}$ & $\begin{array}{l}\text { Upper } \\
\text { Bound }\end{array}$ \\
\hline .411 & .022 & .369 & .454 \\
\hline
\end{tabular}

2. INF

Dependent Variable:SLACK

\begin{tabular}{|l|r|r|r|r|}
\hline \multirow{2}{*}{} & & & \multicolumn{2}{|c|}{$\begin{array}{c}\text { 95\% Confidence } \\
\text { Interval }\end{array}$} \\
\cline { 4 - 5 } INF & & \multicolumn{1}{c|}{$\begin{array}{c}\text { Std. } \\
\text { Error }\end{array}$} & $\begin{array}{r}\text { Lower } \\
\text { Bound }\end{array}$ & $\begin{array}{c}\text { Upper } \\
\text { Bound }\end{array}$ \\
\hline 0 & .248 & .038 & .174 & .323 \\
& & & & \\
1 & .415 & .037 & .341 & .489 \\
2 & .571 & .037 & .498 & .643 \\
\hline
\end{tabular}

3. IDL

Dependent Variable:SLACK

\begin{tabular}{|c|c|c|c|c|}
\hline \multirow[b]{2}{*}{ IDL } & \multirow[b]{2}{*}{ Mean } & \multirow[b]{2}{*}{$\begin{array}{l}\text { Std. } \\
\text { Error }\end{array}$} & \multicolumn{2}{|c|}{$\begin{array}{l}95 \% \text { Confidence } \\
\text { Interval }\end{array}$} \\
\hline & & & $\begin{array}{l}\text { Lower } \\
\text { Bound }\end{array}$ & $\begin{array}{l}\text { Upper } \\
\text { Bound }\end{array}$ \\
\hline 0 & .446 & .032 & .384 & .509 \\
\hline 1 & .376 & .029 & .318 & .434 \\
\hline
\end{tabular}




\section{IDL * INF}

Dependent Variable:SLACK

\begin{tabular}{|c|c|c|c|c|c|}
\hline \multirow[b]{2}{*}{ IDL } & \multirow[b]{2}{*}{ INF } & \multirow[b]{2}{*}{ Mean } & \multirow[b]{2}{*}{$\begin{array}{l}\text { Std. } \\
\text { Error }\end{array}$} & \multicolumn{2}{|c|}{$\begin{array}{c}95 \% \text { Confidence } \\
\text { Interval }\end{array}$} \\
\hline & & & & $\begin{array}{l}\text { Lower } \\
\text { Bound }\end{array}$ & $\begin{array}{l}\text { Upper } \\
\text { Bound }\end{array}$ \\
\hline \multirow[t]{3}{*}{0} & 0 & .268 & .056 & .158 & .378 \\
\hline & 1 & .455 & .056 & .345 & .564 \\
\hline & 2 & .616 & .053 & .511 & .721 \\
\hline \multirow[t]{3}{*}{1} & 0 & .228 & .051 & .127 & .329 \\
\hline & 1 & .375 & .050 & .276 & .474 \\
\hline & 2 & .525 & .051 & .424 & .626 \\
\hline
\end{tabular}

\section{Multiple Comparisons}

Dependent Variable:SLACK

\begin{tabular}{|c|c|c|c|c|c|c|c|}
\hline & \multirow[b]{2}{*}{$\begin{array}{l}\text { (I) } \\
\text { INF }\end{array}$} & \multirow[b]{2}{*}{$\begin{array}{l}(\mathrm{J}) \\
\mathrm{INF}\end{array}$} & \multirow{2}{*}{$\begin{array}{c}\text { Mean } \\
\text { Difference } \\
(\mathrm{I}-\mathrm{J})\end{array}$} & \multirow[b]{2}{*}{$\begin{array}{l}\text { Std. } \\
\text { Error }\end{array}$} & \multirow[b]{2}{*}{ Sig. } & \multicolumn{2}{|c|}{$\begin{array}{l}95 \% \text { Confidence } \\
\text { Interval }\end{array}$} \\
\hline & & & & & & $\begin{array}{l}\text { Lower } \\
\text { Bound }\end{array}$ & $\begin{array}{l}\text { Upper } \\
\text { Bound }\end{array}$ \\
\hline \multirow[t]{6}{*}{ Scheffe } & 0 & 1 & $-.1643^{*}$ & .05282 & .009 & -.2950 & -.0335 \\
\hline & & 2 & $-.3224^{*}$ & .05254 & .000 & -.4524 & -.1923 \\
\hline & 1 & 0 & $.1643^{*}$ & .05282 & .009 & .0335 & .2950 \\
\hline & & 2 & $-.1581^{*}$ & .05226 & .012 & -.2874 & -.0287 \\
\hline & 2 & 0 & $.3224^{*}$ & .05254 & .000 & .1923 & .4524 \\
\hline & & 1 & $.1581^{*}$ & .05226 & .012 & .0287 & .2874 \\
\hline
\end{tabular}

SLACK

\begin{tabular}{|ll|r|c|c|c|}
\hline & & \multicolumn{3}{|c|}{ Subset } \\
\cline { 4 - 6 } & INF & \multicolumn{1}{|c|}{ N } & 1 & 2 & 3 \\
\hline Scheffe $^{\mathrm{a}, \mathrm{b}, \mathrm{c}}$ ( & 0 & 46 & .2464 & & \\
& 1 & 47 & & .4107 & \\
2 & 48 & & & .5688 \\
Sig. & & 1.000 & 1.000 & 1.000 \\
\hline
\end{tabular}


Gambar 3. Grafik Senjangan Anggaran Berdasarkan Idealisme

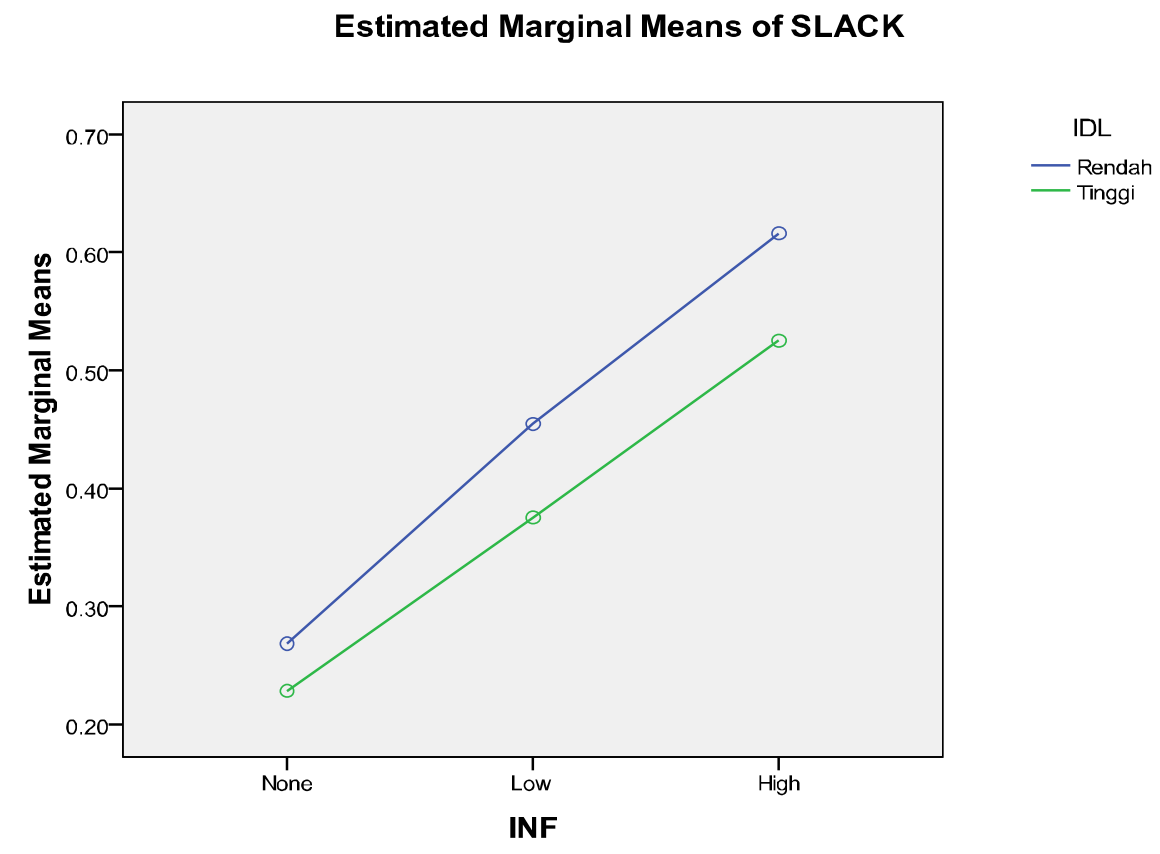

Tabel 34. Uji Hipotesis Asimetri Informasi terhadap Senjangan Anggaran dengan Orientasi Etika sebagai Moderating

\begin{tabular}{|c|c|c|}
\hline \multicolumn{3}{|c|}{ Between-Subjects Factors } \\
\hline & & $\mathrm{N}$ \\
\hline INF & 0 & 46 \\
\hline & 1 & 47 \\
\hline & 2 & 48 \\
\hline ORIENTASI & 0 & 33 \\
\hline ETIKA & 1 & 37 \\
\hline & 2 & 32 \\
\hline & 3 & 39 \\
\hline
\end{tabular}




\section{Descriptive Statistics}

Dependent Variable:SLACK

\begin{tabular}{|c|c|c|c|c|}
\hline INF & ORIENTASI & Mean & $\begin{array}{c}\text { Std. } \\
\text { Deviation }\end{array}$ & $\mathrm{N}$ \\
\hline \multirow[t]{5}{*}{0} & 0 & .2586 & .20873 & 9 \\
\hline & 1 & .2094 & .23646 & 13 \\
\hline & 2 & .2754 & .28643 & 12 \\
\hline & 3 & .2484 & .22491 & 12 \\
\hline & Total & .2464 & .23606 & 46 \\
\hline \multirow[t]{5}{*}{1} & 0 & .4061 & .25179 & 9 \\
\hline & 1 & .3127 & .19761 & 13 \\
\hline & 2 & .4910 & .24676 & 12 \\
\hline & 3 & .4378 & .27897 & 13 \\
\hline & Total & .4107 & .24634 & 47 \\
\hline \multirow[t]{5}{*}{2} & 0 & .5487 & .30430 & 15 \\
\hline & 1 & .4985 & .27830 & 11 \\
\hline & 2 & .7427 & .18813 & 8 \\
\hline & 3 & .5462 & .27988 & 14 \\
\hline & Total & .5688 & .27855 & 48 \\
\hline \multirow[t]{5}{*}{ Total } & 0 & .4307 & .28684 & 33 \\
\hline & 1 & .3316 & .25923 & 37 \\
\hline & 2 & .4731 & .30450 & 32 \\
\hline & 3 & .4184 & .28510 & 39 \\
\hline & Total & .4109 & .28519 & 141 \\
\hline
\end{tabular}


Tests of Between-Subjects Effects

Dependent Variable:SLACK

\begin{tabular}{|l|r|r|r|r|r|}
\hline Source & $\begin{array}{c}\text { Type III Sum } \\
\text { of Squares }\end{array}$ & df & $\begin{array}{c}\text { Mean } \\
\text { Square }\end{array}$ & \multicolumn{1}{c|}{ F } & Sig. \\
\hline Corrected & $2.992^{\mathrm{a}}$ & 11 & .272 & 4.179 & .000 \\
Model & & & & & \\
Intercept & 23.419 & 1 & 23.419 & 359.869 & .000 \\
INF & 2.550 & 2 & 1.275 & 19.593 & .000 \\
ORIENTASI & .447 & 3 & .149 & 2.290 & .081 \\
ETIKA & & & & & \\
INF $*$ & .147 & 6 & .025 & .377 & .893 \\
ORIENTASI & & & & & \\
ETIKA & & & & & \\
Error & 8.395 & 129 & .065 & & \\
Total & 35.194 & 141 & & & \\
Corrected & 11.387 & 140 & & & \\
Total & & & & & \\
\hline
\end{tabular}

\section{Grand Mean}

Dependent Variable:SLACK

\begin{tabular}{|r|r|r|r|}
\hline \multirow{2}{*}{ Mean } & & \multicolumn{2}{|c|}{$\begin{array}{c}95 \% \\
\text { Confidence } \\
\text { Interval }\end{array}$} \\
\cline { 3 - 4 } & Std. Error & $\begin{array}{r}\text { Lower } \\
\text { Bound }\end{array}$ & $\begin{array}{c}\text { Upper } \\
\text { Bound }\end{array}$ \\
\hline .415 & .022 & .371 & .458 \\
\hline
\end{tabular}

\section{INF}

Dependent Variable:SLACK

\begin{tabular}{|c|c|c|c|c|}
\hline \multirow[b]{2}{*}{ INF } & \multirow[b]{2}{*}{ Mean } & \multirow[b]{2}{*}{$\begin{array}{l}\text { Std. } \\
\text { Error }\end{array}$} & \multicolumn{2}{|c|}{$\begin{array}{c}\text { 95\% Confidence } \\
\text { Interval } \\
\end{array}$} \\
\hline & & & $\begin{array}{l}\text { Lower } \\
\text { Bound }\end{array}$ & $\begin{array}{l}\text { Upper } \\
\text { Bound }\end{array}$ \\
\hline 0 & .248 & .038 & .173 & .323 \\
\hline 1 & .412 & .038 & .337 & .486 \\
\hline 2 & .584 & .038 & .509 & .659 \\
\hline
\end{tabular}


3. ORIENTASI ETIKA

Dependent Variable:SLACK

\begin{tabular}{|c|c|c|c|c|}
\hline \multirow[b]{2}{*}{ KLASIFIKASI } & \multirow[b]{2}{*}{ Mean } & \multirow[b]{2}{*}{$\begin{array}{l}\text { Std. } \\
\text { Error }\end{array}$} & \multicolumn{2}{|c|}{$\begin{array}{c}\text { 95\% Confidence } \\
\text { Interval } \\
\end{array}$} \\
\hline & & & $\begin{array}{l}\text { Lower } \\
\text { Bound }\end{array}$ & $\begin{array}{l}\text { Upper } \\
\text { Bound }\end{array}$ \\
\hline 0 & .404 & .046 & .314 & .495 \\
\hline 1 & .340 & .042 & .257 & .423 \\
\hline 2 & .503 & .046 & .412 & .594 \\
\hline 3 & .411 & .041 & .330 & .492 \\
\hline
\end{tabular}

4. INF * ORIENTASI ETIKA

Dependent Variable:SLACK

\begin{tabular}{|c|c|c|c|c|c|}
\hline \multirow[b]{2}{*}{ INF } & \multirow[b]{2}{*}{$\begin{array}{l}\text { ORIENTASI } \\
\text { ETIKA }\end{array}$} & \multirow[b]{2}{*}{ Mean } & \multirow[b]{2}{*}{$\begin{array}{l}\text { Std. } \\
\text { Error }\end{array}$} & \multicolumn{2}{|c|}{$\begin{array}{l}\text { 95\% Confidence } \\
\text { Interval }\end{array}$} \\
\hline & & & & $\begin{array}{l}\text { Lower } \\
\text { Bound }\end{array}$ & $\begin{array}{l}\text { Upper } \\
\text { Bound }\end{array}$ \\
\hline \multirow[t]{4}{*}{0} & 0 & .259 & .085 & .090 & .427 \\
\hline & 1 & .209 & .071 & .069 & .349 \\
\hline & 2 & .275 & .074 & .130 & .421 \\
\hline & 3 & .248 & .074 & .103 & .394 \\
\hline \multirow[t]{4}{*}{1} & 0 & .406 & .085 & .238 & .574 \\
\hline & 1 & .313 & .071 & .173 & .453 \\
\hline & 2 & .491 & .074 & .345 & .637 \\
\hline & 3 & .438 & .071 & .298 & .578 \\
\hline \multirow[t]{4}{*}{2} & 0 & .549 & .066 & .418 & .679 \\
\hline & 1 & .498 & .077 & .346 & .651 \\
\hline & 2 & .743 & .090 & .564 & .921 \\
\hline & 3 & .546 & .068 & .411 & .681 \\
\hline
\end{tabular}


SLACK

\section{Multiple Comparisons}

Scheffe

\begin{tabular}{|ll|c|c|c|c|c|}
\hline & & & & & \multicolumn{2}{c|}{$\begin{array}{c}95 \% \\
\text { Confidence } \\
\text { Interval }\end{array}$} \\
\cline { 6 - 8 } & & $\begin{array}{c}\text { Mean } \\
\text { Difference } \\
(\mathrm{I}) \mathrm{INF}\end{array}$ & $\begin{array}{c}\text { Std. } \\
\text { Error }\end{array}$ & Sig. & $\begin{array}{c}\text { Lower } \\
\text { Bound }\end{array}$ & $\begin{array}{c}\text { Upper } \\
\text { Bound }\end{array}$ \\
\hline 0 & $(\mathrm{~J}) \mathrm{INF}$ & $-.1643^{*}$ & .05291 & .010 & -.2953 & -.0332 \\
& 1 & $-.3224^{*}$ & .05264 & .000 & -.4527 & -.1920 \\
\hline 1 & 2 & $.1643^{*}$ & .05291 & .010 & .0332 & .2953 \\
& 0 & $-.1581^{*}$ & .05235 & .012 & -.2877 & -.0284 \\
\hline 2 & 2 & $.3224^{*}$ & .05264 & .000 & .1920 & .4527 \\
& 0 & $.1581^{*}$ & .05235 & .012 & .0284 & .2877 \\
\hline
\end{tabular}

SLACK

Scheffe $e^{a, b,, c}$

\begin{tabular}{|l|rr|r|r|c|}
\hline & & \multicolumn{3}{|c|}{ Subset } \\
\cline { 3 - 6 } INF & $\mathrm{N}$ & 1 & 2 & 3 \\
\hline 0 & & 46 & .2464 & & \\
1 & 47 & & .4107 & \\
2 & & 48 & & & .5688 \\
Sig. & & & 1.000 & 1.000 & 1.000 \\
\hline
\end{tabular}


SLACK

\section{Multiple Comparisons}

Scheffe

\begin{tabular}{|c|c|c|c|c|c|c|}
\hline \multirow{3}{*}{$\begin{array}{l}\text { (I) } \\
\text { ORIENTASI } \\
\text { ETIKA }\end{array}$} & \multirow{3}{*}{$\begin{array}{l}(\mathrm{J}) \\
\text { ORIENTASI } \\
\text { ETIKA }\end{array}$} & \multirow{3}{*}{$\begin{array}{c}\text { Mean } \\
\text { Difference } \\
(\mathrm{I}-\mathrm{J})\end{array}$} & \multirow{3}{*}{$\begin{array}{c}\text { Std. } \\
\text { Error }\end{array}$} & \multirow[b]{3}{*}{ Sig. } & \multicolumn{2}{|c|}{$\begin{array}{c}95 \% \\
\text { Confidence } \\
\text { Interval }\end{array}$} \\
\hline & & & & & Lower & Upper \\
\hline & & & & & Bound & Bound \\
\hline \multirow[t]{3}{*}{0} & 1 & .0991 & .06108 & .455 & -.0740 & .2721 \\
\hline & 2 & -.0424 & .06329 & .930 & -.2217 & .1369 \\
\hline & 3 & .0122 & .06034 & .998 & -.1587 & .1832 \\
\hline \multirow[t]{3}{*}{1} & 0 & -.0991 & .06108 & .455 & -.2721 & .0740 \\
\hline & 2 & -.1415 & .06158 & .158 & -.3159 & .0330 \\
\hline & 3 & -.0868 & .05854 & .534 & -.2527 & .0790 \\
\hline \multirow[t]{3}{*}{2} & 0 & .0424 & .06329 & .930 & -.1369 & .2217 \\
\hline & 1 & .1415 & .06158 & .158 & -.0330 & .3159 \\
\hline & 3 & .0546 & .06085 & .848 & -.1177 & .2270 \\
\hline \multirow[t]{3}{*}{3} & 0 & -.0122 & .06034 & .998 & -.1832 & .1587 \\
\hline & 1 & .0868 & .05854 & .534 & -.0790 & .2527 \\
\hline & 2 & -.0546 & .06085 & .848 & -.2270 & .1177 \\
\hline
\end{tabular}

SLACK

Scheffe $\mathrm{e}^{\mathrm{a}, \mathrm{b}, \mathrm{c}}$

\begin{tabular}{|c|c|c|}
\hline \multirow{2}{*}{$\begin{array}{l}\text { ORIENTASI } \\
\text { ETIKA }\end{array}$} & \multirow[b]{2}{*}{$\mathrm{N}$} & Subset \\
\hline & & 1 \\
\hline 1 & 37 & .3316 \\
\hline 3 & 39 & .4184 \\
\hline 0 & 33 & .4307 \\
\hline 2 & 32 & .4731 \\
\hline Sig. & & .151 \\
\hline
\end{tabular}


Gambar 4. Grafik Senjangan Anggaran Berdasarkan Exceptionist, Absolutist, Subjectivist, dan Situationist

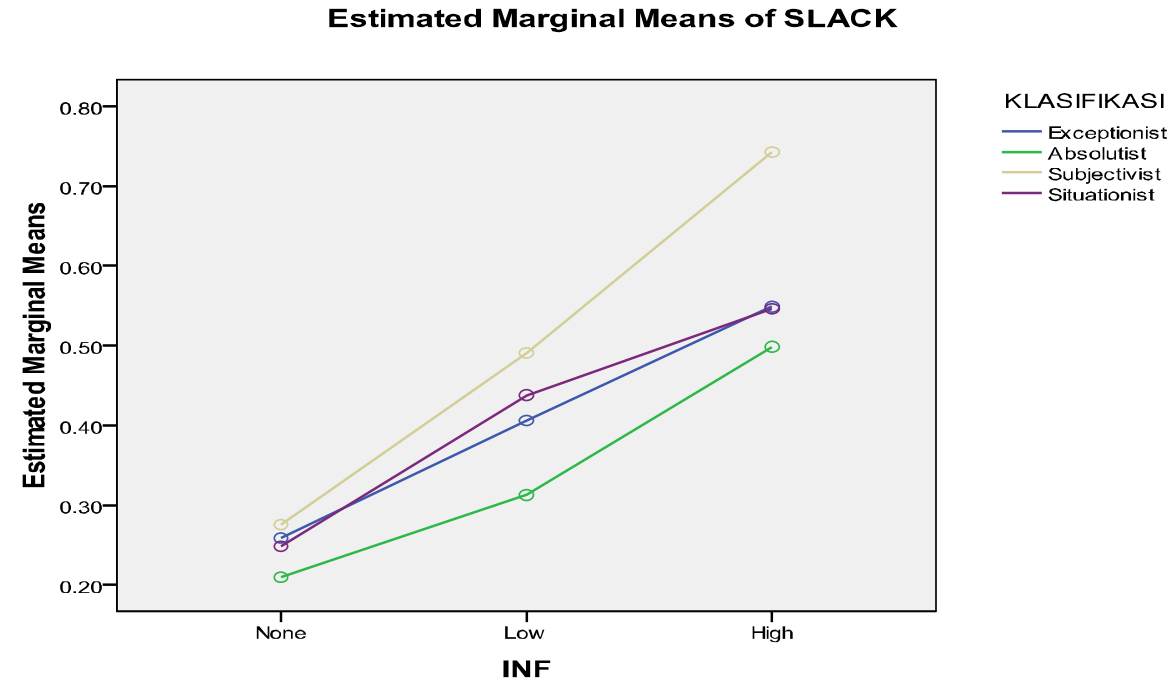

